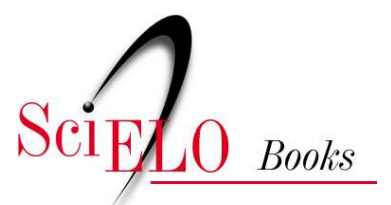

\title{
História social da tuberculose e do tuberculoso: 1900-1950
}

\author{
Claudio Bertolli Filho
}

\section{SciELO Books / SciELO Livros / SciELO Libros}

BERTOLLI FILHO, C. História social da tuberculose e do tuberculoso: 1900-1950 [online]. Rio de Janeiro: Editora FIOCRUZ, 2001. 248p. Antropologia \& Saúde collection. ISBN 85-7541-006-7. Available from SciELO Books <http://books.scielo.org>.

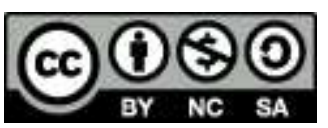

All the contents of this chapter, except where otherwise noted, is licensed under a Creative Commons Attribution-Non Commercial-ShareAlike 3.0 Unported.

Todo o conteúdo deste capítulo, exceto quando houver ressalva, é publicado sob a licença Creative Commons Atribuição Uso Não Comercial - Partilha nos Mesmos Termos 3.0 Não adaptada.

Todo el contenido de este capítulo, excepto donde se indique lo contrario, está bajo licencia de la licencia Creative Commons Reconocimento-NoComercial-CompartirIgual 3.0 Unported. 


\section{História Social da Tuberculose e do Tuberculoso: 1900-1950}

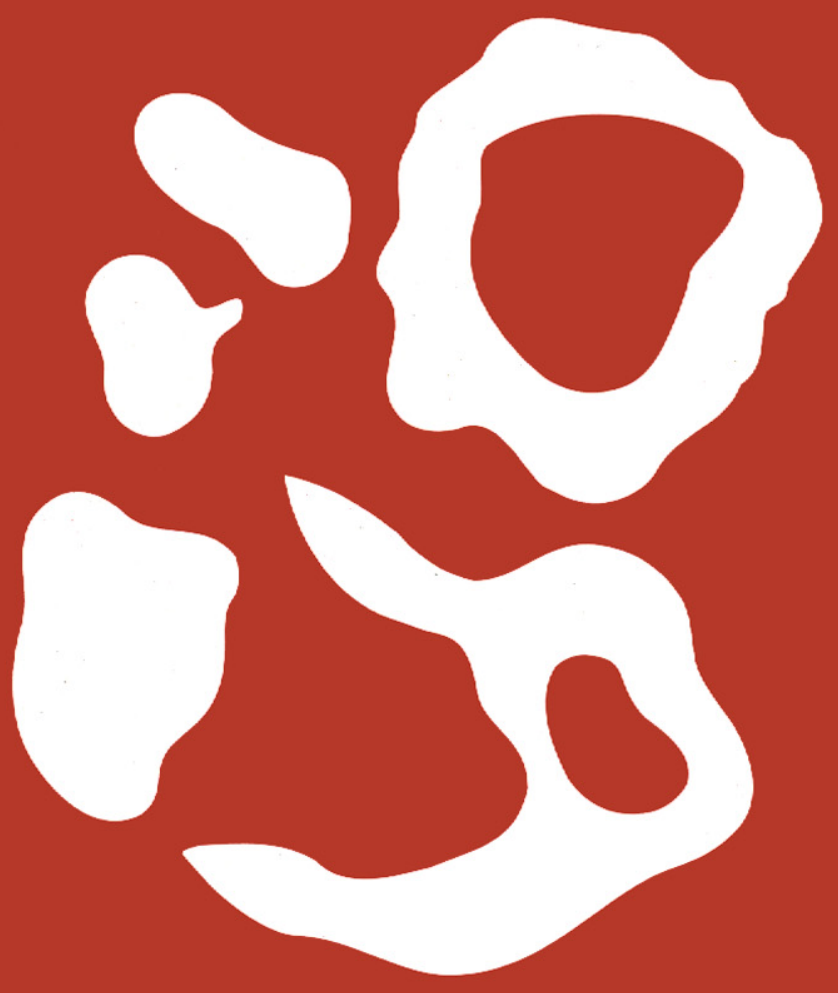

Claudio Bertolli Filho 
História Social da Tuberculose e do Tuberculoso: 1900-1950

Claudio Bertolli Filho é já há muito referência na área de História da Saúde. Doutor em História Social pela Universidade de São Paulo (USP) e professor de Antropologia da Universidade Estadual Paulista (Lnesp), é um pesquisador da História com aguçado olhar antropológico.

A intenção de seu livro é estudar o homem enfermo, recuperá-lo como personagem de expressividade histórica, dando-Ihe voz e revelando-nos seus sentimentos. Para tanto, Bertolli desvenda a doença que conforma os fracos do peito, os especialistas, as instituiçōes que os abrigam e as relaçōes sociais nas quais se vêem envolvidos. $O$ cenário em que se desenrola esta história é o Brasil nos primeiros cinqüenta anos do século passado.

Em História Social da Tuberculose e do Tuberculoso, o autor percorre o processo de constituição do ideário sobre a doença no Brasil, analisando os comportamentos individuais e coletivos frente à enfermidade. Nesse estudo nada the escapa, Claudio Bertolli Filho envereda por inúmeros temas, mesclando narrativa literária e discurso científico, num fascinante enredo que abarca as interpreta- 


\section{História Social da Tuberculose e do Tuberculoso: 1900-1950}




\section{FUNDAÇÃOOSWALDO CRUZ}

Presidente

Paulo Marchiori Buss

Vice-Presidente de Desenvolvimento Institucional,

Informação e Comunicação

Paulo Gadelha

\section{EDITORAFIOCRUZ}

Coordenador

Paulo Gadelha

Conselho Editorial

Carlos E. A. Coimbra Jr.

Carolina M. Bori

Charles Pessanha

Hooman Momen

Jaime L. Benchimol

José da Rocha Carvalheiro

Luis David Castiel

Luiz Fernando Ferreira

Maria Cecília de Souza Minayo

Miriam Struchiner

Paulo Amarante

Vanize Macêdo

Zigman Brener

Coordenador Executivo

João Carlos Canossa P. Mendes

Coleção Antropologia e Saúde

Editores Responsáveis: Carlos E. A. Coimbra Jr.

Maria Cecília de Souza Minayo 


\section{História Social da Tuberculose e do Tuberculoso: 1900-1950}

Claudio Bertolli Filho 
Copyright $^{\oplus} 2001$ by Claudio Bertolli Filho

Todos os direitos desta edição reservados à

FundaÇão OsWALdo CRUZ / EdITORA

ISBN: 85-7541-006-7

Projeto Gráfico e Editoração Eletrônica:

Angélica Mello

Capa:

Danowski Design

Ilustração da Capa:

A partir de desenho de Hans Arp, Crumpled paper, 1958. Foundation Arp, Clamart.

Revisão e Copidesque:

Ana Tereza de Andrade

Catalogação-na-fonte

Centro de Informação Científica e Tecnológica

Biblioteca Lincoln de Freitas Filho

R546h Bertolli Filho, Claudio

História Social da Tuberculose e do Tuberculoso: 1900-1950 / Claudio Bertolli Filho. Rio de Janeiro: Editora FIOCRUZ, 2001.

248p. (Coleção Antropologia \& Saúde)

1. Tuberculose - história - Brasil - 1900-1950. 2. Efeitos psicossociais da doença.

CDD - 20.ed. -616.9950981

2001

EDITORA FIOCRUZ

Av. Brasil, 4036 - $1^{\circ}$ andar - sala 112 - Manguinhos

21040-361 - Rio de Janeiro - RJ

Tels: (21) 3882-9006/3882-9039/3882-9041/3882-9008

Fax: (21) 3882-9007

e-mail: editora@fiocruz.br

http//:www.fiocruz.br 


\section{SUMÁRI0}

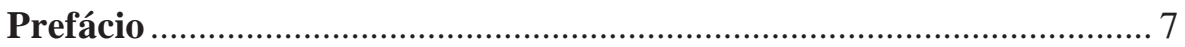

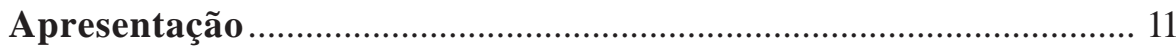

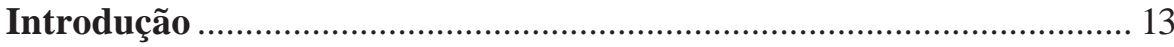

PARTE I: IDÉIAS E CONTROVÉRSIAS

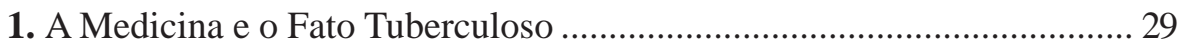

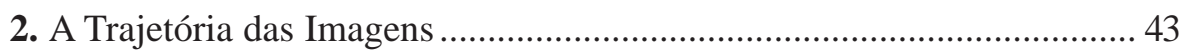

3. Administração Sanitária e Tuberculose no Brasil ....................................... 57

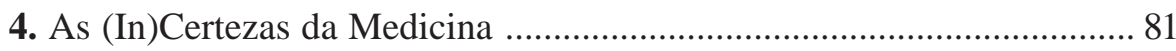

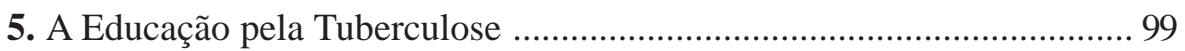

PARTE II: Personagens e Cenários

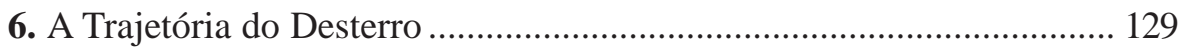

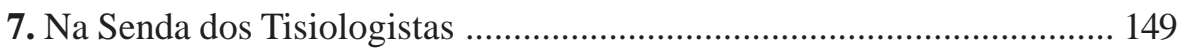

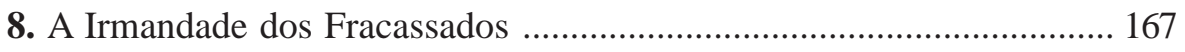

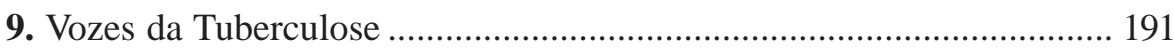

10. Os Caminhos da Vida e da Ciência ................................................... 215

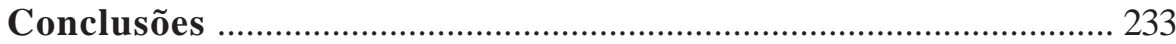

Referências Bibliográficas ............................................................... 237 


\section{Prefácio}

\section{Mais que Prefácio, um Reconhecimento}

Aristóteles dizia que o espanto é uma boa fonte de saber. O livro de Claudio Bertolli Filho, neste sentido, garante essa afirmativa. Valendo-se de uma incrível variedade de documentos, usando-os de maneira fluida e esperta, a construção do texto retraça uma história complexa e provocante, rica em detalhes e integral nas explicações. Pesquisa, paixão e tenacidade fazem deste texto um elogio à competência.

Sem dúvida, é uma história tecida sob as luzes da Antropologia ou talvez um texto de Antropologia alimentado pela perspectiva histórica e que foi originalmente defendido como tese de doutorado na Universidade de São Paulo. Hoje desbastada dos andaimes acadêmicos, o que era mais um teste profissional virou livro de interesse amplíssimo. Como um repertório de referências abertas à Antropologia e à História, além de comprometido com Sociologia, Estudos Biomédicos e Científicos, Cultura Popular e de Massa e ainda com a Crítica Literária, este livro aponta para paradoxos que não se encerram no simplista chavão 'multidisciplinar'. A erudição na matéria convocou saberes de outras especialidades para compor uma História/Antropologia atualizada em termos de síntese e formulação de um objeto senão novo, pouco estudado.

A leitura fácil enreda níveis de entendimento que arrolam debates cruciais da Historiografia contemporânea. O texto aborda os limites da ação do Estado e das Ciências Médicas na parte que lhes cabe na construção da doença e do doente, a fragilidade das 'instituições totais', o acaso como acidente marginal às programações dos profissionais da saúde. Fala também de crenças religiosas, de solidão e desencanto com as instituições. Os fios coloridos desenrolados de linhagens múltiplas tecem um pano de fundo que cobre a organização de classe, os dilemas políticos, a precariedade dos sistemas urbanos brasileiros e a importação de padrões estrangeiros contrastada com um certo localismo resistente aos modelos de tratamento e cura.

Talvez a operação mais difícil cumprida pelo autor esteja no equilíbrio entre o caráter universal da doença, bem como de sua repercussão global, e os limites do tratamento do assunto em âmbito nacional brasileiro que, a todo custo, busca apresentar-se como moderno, afinado com as propostas articuladas pela Medicina e pela Administração Sanitária formuladas nos centros europeus e norte-americanos e, ao mesmo tempo, empreender a difícil tarefa de conferir uma dimensão nacional a tudo que se referia à tuberculose e ao tuberculoso. Não menos sofisticado e pertinente é o cuidado em perpassar o progresso historiográfico calcado na superação da Nova 
História, da História das Mentalidades e mesmo a fragilidade da História da Vida Privada. Renovando a noção de História Projeto, o autor avança para a História da Vida Íntima e para a Antropologia de Geertz e assim estabelece os vínculos entre pontas opostas do mesmo novelo: as estruturas do Estado e as pessoas, individualmente. O macro histórico contendo o mínimo, individual, ou o micro justificado na estrutura macro funcionam como a realização da proposta de Deleuze em associar o 'acorde/acordo' pleno de satisfação no conjunto de relações infinitamente pequenas que se integram na cadeia explicativa dos fatos, das pessoas e da sociedade. Explicações da vida e da morte de uma legião de infectados, assim como das tentativas médicas e políticas de se defrontar com um desafio que colocava em aberto uma sociedade, uma cultura e todo um tempo.

A sedução do texto chega a ser perversa. Mesclando personagens da vida cotidiana, populares anônimos ordinários, com figuras de destaque do mundo político, artístico e científico, vemo-nos, todos familiarizados com nomes, datas, eventos, lugares. Não há como negar o duplo movimento que se exerce durante a leitura deste livro. Caminhando pela senda da lógica narrativa - inteligente, instruída e rápida - evocamos, naturalmente, a memória e assim procedemos a um exercício de lembrança e rememorações que nos joga dramaticamente para a cena dos acontecimentos. E perguntamos: afinal, de quem é esta História? Da tuberculose, do Brasil, dos meus ou seus antepassados familiares?

É preciso dizer ainda que o tema poderia ser enquadrado no âmbito do que tem se reconhecido como 'História Social da Saúde'. Vale, no entanto, notar que a área médica ou de estudos biomédicos tem proposto um procedimento especular para a análise dos fenômenos sociais: a apropriação dos problemas de saúde como uma forma de contemplar o sistema político em sua expressão maior.

Nesse sentido, como já o fez antes Claudio Bertolli Filho ao ver a gripe espanhola, aponta para os fatores culturais que levam a uma naturalização de aspectos genéricos e os efeitos sociais dessa reversão esculpem uma nova imagem dos possíveis históricos. O mais notável é que nessa operação não se perde de vista o enquadramento historiográfico e conjuntural do problema. Com a tuberculose, fenômeno tão planetário, o cuidado com o tema implicou na recuperação de seus registros de raiz, desde a remota Antigüidade até as manifestações mais graves, endêmicas ou epidêmicas, e sua instalação como ponto de conflito entre o político e corpo social contemporâneo.

A utilização dos Prontuários Médicos, em meio a um universo de outros documentos, indica o teor social dos registros que dimensionam tanto o sofrimento do paciente como as mediações que desumanizavam o doente, no caso, o turberculoso no Brasil. A conjugação das fontes documentais permitiu que o alinhavo do texto se desse sobretudo pelo prisma cultural. Fala-se, portanto, de uma cultura que se desdobra em nome da tuberculose, instigando profissionais da saúde - muitos deles reunindo a condição de especialistas científicos e tuberculosos - , infectados e a sociedade em geral repensar suas práticas e inserções no cotidiano sob o amedrontado prisma da Peste Branca. No alinhavo entre o científico e o político, o público e o privado, o individual e o coletivo, o autor confere um sentido inovador à trama cultural em sua dimensão brasileira, desvelando um cenário consistente e esclarecedor da doença, dos doentes e de todos os envolvidos na tragédia regida pela tuberculose. 
Por fim, é válido testemunhar uma vocação autêntica. Tendo conhecido o autor como aluno, nos bancos de um curso de História, na graduação, vê-lo transformado em autoridade é mais que uma emoção de professor. Como historiador, aquilatar o trabalho desse estudioso é reconhecer a delícia de ser aprendiz.

José Carlos Sebe Bom Meihy Professor titular da Faculdade de Filosofia, Letras e Ciências Humanas da Universidade de São Paulo 


\section{Apresentação}

O texto que se apresenta foi arquitetado em duas grandes partes. A primeira parte, intitulada “Idéias e controvérsias”, é composta dos primeiros cinco capítulos do livro e busca situar a tuberculose como questão polifônica.

A presença da doença e do doente em diferentes conjunturas históricas e o enquadramento de ambos como ‘ameaças’ à vida coletiva incentivou as ciências médicas a decifrar o enigma representado pela tuberculose e pelo tuberculoso, resultando em discursos sobretudo convergentes e justificados por pesquisas laboratoriais e por análises epidemiológicas. Ao mesmo tempo, a cultura ocidental construía um inusitado número de imagens sobre os doentes do peito, buscando na medicina justificativas legitimadoras das imagens, da mesma maneira que os médicos encontravam na trama cultural motivos e argumentações para suas conclusões clínico-epidemiológicas.

Transferidas para o contexto nacional, as proposições médicas e as representações sociais sobre os tísicos cobravam iniciativas oficiais e filantrópicas, abrindo oportunidades para que fosse possível realizar-se o estudo do gerenciamento sanitário da Peste Branca e das estratégias e conteúdos educadores impostos aos tuberculosos.

Estabelecido o pano de fundo, a segunda parte do texto, denominada "Personagens e cenários”, é composta pelos últimos cinco capítulos, focando a trajetória socialmente elaborada para os tísicos, oferecendo elementos para uma possível 'cultura dos tuberculosos’ e surgimento do espírito comunitários que os faziam sentir-se membros de uma espécie de 'irmandade’ construída pela doença e pela exclusão do mundo dos sadios e pela permanência por longos períodos - senão pelo resto da vida - em sanatórios ou em cidades sanitárias, dimensões que sofreram sensíveis alterações quando obteve-se o primeiro quimioterápico específico contra a terrível enfermidade.

Este livro é produto revisto da minha tese de doutorado apresentada à Faculdade de Filosofia, Letras e Ciências Humanas da Universidade de São Paulo, na primavera de 1992, sob a orientação do Prof. Dr. José Carlos Sebe Bom Meihy, contando com o apoio da bolsa oferecida pelo Programa de Capacitação Docente do Capes.

Foram Muitas as pessoas e as instituições que me ajudaram nesta tarefa, sobretudo os docentes do Departamento de Medicina Social da Faculdade de Ciências Médicas da Santa Casa de São Paulo, especialmente os Professores Doutores Regina Marsiglia, Nelson Ibañez e Mario Sposati, que há duas décadas ensinam-me o sentido histórico-social dos eventos médico-sanitários, tanto no plano coletivo, quanto na esfera individual.

Apesar dos posicionamentos assumidos neste texto serem de responsabilidade exclusiva do autor, algumas pessoas tornaram-se fundamentais na sua formulação, somando ao apoio acadêmico um afeto imprescindível: Ana Maria, José Carlos e Mário 
incentivaram-me a estudar a tuberculose e os tuberculosos ao mesmo tempo que se postaram como rígidos avaliadores de tudo que eu escrevia. Na seqüência, a professora Teresinha de Fátima Nogueira e a minha filha, Alice, ofereceram-me novos motivos para ir em frente. Mais recentemente, minha esposa, Raquel, e a nossa pequena Laura impuseram novos rumos à minha vida e fizeram com que a tese universitária finalmente se transformasse em livro, sendo a elas dedicada esta obra. A todas as pessoas mencionadas, minha gratidão e meu amor. 


\section{Introdução}

Como pode haver qualquer revolução verdadeira enquanto não soubermos do que somos feitos?

Graham Swift

O empenho de elaboração de um estudo sobre a História Social da Doença e do Doente, especificamente da tuberculose e do tuberculoso, desdobra-se em duas questões preliminares. Primeiramente, indaga-se da possibilidade de uma história da enfermidade e de seus tributários e, em continuidade, dos motivos contextuais de uma pesquisa centrada nos personagens motivados pela Peste Branca.

Nas origens desta pesquisa, encontram-se os compromissos em retraçar os meandros temáticos e metodológicos que possibilitam o dimensionamento do 'território do historiador’. As últimas décadas foram marcadas por um número crescente de pesquisas na área da História Social, voltados para a pobreza, para a violência, para a sexualidade, para o trabalho e para o lazer, entre outros. Estes trabalhos apontam para uma História emergente por meio da convergência das condições materiais de vida e dos comportamentos coletivos. Nesta trajetória, ‘tipos sociais’ até então preteridos em prol dos 'grandes personagens' têm chamado a atenção dos estudiosos: o negro rebelde, a doméstica, a prostituta, o homossexual, o índio e o malandro são alguns desses protagonistas que têm despertado renovados interesses, oferecendo chances para a releitura da sociedade.

Dentre tantos personagens que reclamam pelo tratamento mais conseqüente das Ciências Humanas, encontra-se o Homem enfermo. Apesar da experiência com a doença ser condição própria da vida - portanto, um fato social - a História e as Ciências Sociais pouco ainda contemplaram o tema com olhos criteriosos.

A atenção às doenças e aos doentes como centro de múltiplos filigramas do tecido coletivo implicou na escolha da tuberculose como um dos temas de relevo para estudo. Isto porque a Peste Branca foi definida desde os meados do século passado como 'moléstia social' que, alinhada à sífilis e ao alcoolismo, constituíram-se num dos principais conjuntos desafiadores da ordem social, inerente ao contexto das revoluções burguesas.

Com isto, a tísica e suas vítimas tornaram-se objetos exaustivamente vistoriados pela medicina, principalmente a partir do século XIX. Desde então, a continuidade dos enfoques incentivados pelos interesses e pelos medos coletivos elevaram a tuberculose e os fracos do peito a representantes máximos da potencialidade deletéria do cotidiano urbano-industrial, justificando a necessidade e a urgência do estudo da tísica e dos tísicos. Assim, analisar-se-ia também a sociedade e suas estruturas como um todo. 
Os cinqüenta primeiros anos do século passado balizam temporalmente, grosso modo, o presente estudo sobre a tuberculose e seus envolvidos, no contexto brasileiro. A opção pela marca cronológica inicial deve-se à ocorrência de vários fenômenos concomitantes, por exemplo: se no contexto internacional ganhava impulso a teoria pastoriana que permitiu, inclusive, a identificação do bacilo de Koch como o agente biológico causal da infecção pulmonar, no Brasil, as ações direcionadas para a institucionalização da Peste Branca e dos pectários deram-se paralelamente à redefinição do moderno Estado Nacional e ao processo de organização da sociedade de classes. Como marco cronológico final, estabeleceu-se a metade do século XX porque então já se dispunha de estratégias relativamente eficientes para o ‘controle’ da tuberculose, ao passo que os principais centros urbanos do país eram tidos como áreas regidas pelos códigos da modernidade.

Por óbvio, não se pretende o enclausuramento analítico - nem sua exaustão -, no meio século assinalado. Tão antiga quanto a própria Humanidade, a tuberculose já contava com uma longa trajetória quando colocou-se como assunto preocupante no Brasil. Esta condição, que sugere o alargamento das perspectivas temporais, permite que luzes antigas sejam utilizadas para o entendimento do período realçado no estudo, exigindo também a nitidez que convida recortes. Recortes que, contudo, devem ser reinseridos no mosaico mais amplo.

O entrelaçamento dos eventos assinalados como balizadores desta pesquisa não é fortuito. As preocupações nacionais com a tuberculose tomaram impulso a partir dos últimos anos do século XIX, no momento em que o país buscava se realinhar no contexto internacional, necessitando para isto 'regenerar' a população que vinha sendo platonicamente concebida como um ‘povo’ organicamente articulado.

Fenômeno sobretudo urbano, a tísica reclamava soluções, as quais foram engendradas segundo os interesses das elites acantonadas nas capitais, em particular em São Paulo e no Rio de Janeiro. É certo que houve desdobramentos das medidas intervencionistas da Saúde Pública para outras áreas, mas, na ordem da modernização, os centros urbanos de maior densidade populacional se destacaram.

Juntando-se os fios, define-se o objeto desta pesquisa: o entendimento da tuberculose e de suas vítimas, no contexto do processo modernizador das grandes estruturas da sociedade, dando-se especial ênfase aos olhares e às ações alimentadas pelos paulistas e cariocas frente ao dilema sanitário.

As relações historicamente estabelecidas entre a Sociedade e os Indivíduos enfermos constitui-se na estratégia problematizadora deste livro. Em conformidade com a documentação disponível e com o recorte temporal admitido, buscou-se questionar os elementos norteadores da experiência social que aproximava os sadios dos pectários, bem como as vertentes assumidas pelo processo de constituição do ideário tisiológico nacional. Como elemento articulador destes eventos, localiza-se a trama histórica marcada pelo empenho redefinidor da economia e da sociedade brasileira e, por extensão, os comportamentos individuais e coletivos frente à infecção pulmonar. Fala-se, pois, de vida privada e suas interações com o público. Fala-se também da contextualização brasileira de um fenômeno universal. 
Estabelecido o norte desta pesquisa, ocorre a multiplicação dos questionamentos. Qual foi a especificidade dos liames entre a institucionalização da ameaça tuberculosa e o processo de modernização nacional? Quais foram os papéis desempenhados pelo segmento médico-educador na tarefa atualizadora do perfil epidemiológico brasileiro, em conformidade com os modelos representados pelos Estados Unidos e por outros países 'civilizados'? Como foi que, no Brasil, os consuntivos reagiram em face do tratamento social que lhes era dispensado? Enfim, como os indivíduos - sadios ou enfermos, médicos ou leigos - responderam aos direcionamentos formulados pelo conjunto das instituições sociais?

Livros e artigos médicos, prontuários clínicos, relatórios de instituições públicas e privadas, depoimentos orais, obras memorialísticas e biográficas, composições literárias e artigos jornalísticos, além da bibliografia nacional e estrangeira sobre o tema foram os principais pontos de apoio para a elaboração do presente livro. O fato da História Social da Doença e do Doente contar com múltiplas ramificações, exigiu a recorrência a uma diversidade de fontes documentais, impondo o rastreamento de numerosas bibliotecas, arquivos, museus e 'sebos'.

Apesar da pluralidade de informações, a variedade documental resultou favorável para o desdobramento do estudo. Sob esta perspectiva, tudo ganha dimensão maior quando o tema tratado constitui-se na tuberculose e no tuberculoso, pois ambos os tópicos revelam-se, por excelência, fenômenos resultantes da malha social brasileira. Os diferentes nexos discursivos que instruem os núcleos documentais aproximam a experiência individual às reações coletivas frente à enfermidade e as medidas preconizadas pelos serviços de Saúde Pública aos modelos higienistas internacionais, elucidando as linhas conflituosas que emprestam compasso reticente aos debates nutridos pelo peso mortífero da Peste Branca entre nós.

Do conjunto de documentos explorados neste livro, a produção literária, os prontuários clínicos e os depoimentos orais ganharam destaques próprios, sendo necessário por isso maiores averiguações sobre o sentido atribuído a estas fontes primárias na composição da pesquisa.

Apesar da constância dos pronunciamentos críticos que pontificam que 'Literatura não é documento', o emprego de obras ficcionais como respaldo para o entendimento da tuberculose ganhou interesse pelo fato dos médicos e também os leigos de décadas passadas recorrerem às composições literárias para abordar as 'fraquezas humanas' que marcavam os comportamentos dos enfermos em geral e, em especial, o que foi denominado como 'psicologia' dos doentes do peito.

O crédito de veracidade emprestado às páginas romanescas mantinha-se como uma atitude disseminada, coagindo os clínicos a somarem as fórmulas hipocráticas aos ensinamentos literários no entendimento da clientela consuntiva. Por isso, o Dr. Clementino Fraga (1942) - um dos principais mestres da tisiologia nacional nos anos 30 - justificou o interesse médico pela produção ficcional por esta compreender análises da vida pública e privada dos doentes, indicando as obras literárias como fonte abalizada para o estudo dos 'sentimentos dos pacientes'.

Seguindo estes ensinamentos, o Dr. Gastão Pereira da Silva (1959), ao fazer um balanço dos primeiros anos da prática psicanalítica no Brasil, apresentou o escritor 
Thomas Mann como um dos principais especialistas no setor clínico que estava sendo avaliado, alegando que ninguém estudou tão profundamente a 'alma humana' quanto o romancista alemão.

A pena inspirada na 'Literatura experimental' fez Émile Zola discípulo de Claude Bernard, selando uma duradoura aliança entre os escritores e os médicos. As descrições muitas vezes tétricas sobre a vida e a morte dos consuntivos impregnaram de horror muitas laudas ficcionais, deixando a impressão de que seus autores haviam convivido intimamente com os personagens infectados - talvez sendo eles próprios vítimas da fimatose pulmonar.

Neste encaminhamento, as obras de ficção assemelham-se aos relatórios etnográficos que se comprazem no registro de até mínimos detalhes do cotidiano e das intenções do grupo que está sendo estudado. Lidos por alguns e disseminados de boca em boca - e também pelas ondas radiofônicas e pelo cinema -, os textos literários integravam-se como assunto de conhecimento amplo, conferindo redobrado vigor às mensagens discriminadoras dos doentes do peito e, na seqüência, instruindo as reações médicas e leigas frente aos infectados. Assim, tematizada pela tuberculose, a literatura torna-se documentação de verificação obrigatória pelos historiadores e cientistas sociais (Laplantine, 1991).

Enquanto 'doença da moda', a Peste Branca tornou-se motivo explorado por escritores de prestígio e também por autores estreantes e às vezes pectários, os quais buscavam compartilhar o drama íntimo com a infecção e ao mesmo tempo ganhar reconhecimento intelectual.

Em nível teórico, o alerta feito por Henry Zalamansky (1970) sobre a necessidade de distinção entre as composições preparadas pelos ficcionistas de ampla aceitação editorial e que, portanto, sentem-se livres para oferecer enfoques originais e o teor da escrita dos novatos, que tendem a reproduzir o que os leitores estariam dispostos a absorver, parece fenômeno diluído no conjunto dos romances que contam com personagens infectados. Isto porque a tuberculofobia, imperante no período analisado, incitava os autores, os editores e o público a adotarem perspectivas convergentes, conferindo encaminhamentos semelhantes às tramas literárias baseadas na infecção pulmonar.

Os prontuários médicos, por sua vez, apresentam-se como outro núcleo valioso para a análise da rotina institucional dos centros tisiológicos e também dos posicionamentos assumidos pelos clínicos e pelos seus pacientes. Até o presente, tais registros praticamente não foram explorados pelos pesquisadores da área das Ciências Humanas, exceto em algumas situações em que os prontuários foram empregados sobretudo como ilustração ou mesmo curiosidade, com diminuta preocupação sobre a especificidade desta fonte.

No Brasil, esta documentação começou a ser produzida no momento da instalação das primeiras escolas médicas, na aurora do século XIX, sendo que a política de padronização e preservação por alguns anos dos registros clínicos ganhou incentivo a partir de 1943, quando tiveram início os estudos para a organização do Serviço de Arquivo Médico e Estatística, que seria implantado no Hospital das Clínicas da Faculdade de Medicina da Universidade de São Paulo, que estava em fase de construção. 
A possibilidade de encontrar esse tipo de documento, entretanto, é difícil. Da legislação que define a obrigatoriedade dos nosocômios preservarem os seus registros clínicos, por um prazo máximo de dez anos, decorre que, periodicamente, uma parcela significativa do pretérito sanitário nacional acabe sendo destruída. A utilização pelos pesquisadores de prontuários datados de mais de uma década, portanto, é fato incomum, acrescentando-se ainda outros obstáculos para o emprego desta fonte documental: o campo conceitual exclusivo do saber médico-biológico, os códigos e abreviaturas às vezes criados e instituídos segundo a conveniência de uma única casa de saúde e as muitas vezes indecifráveis caligrafias dos esculápios.

Além disso, deve-se acrescentar a dificuldade dos estudiosos não médicos obterem permissão de acesso a esta documentação já que, sob o compromisso de preservar o sigilo médico, as entidades hospitalares tendem a negar autorização de consulta aos relatórios clínicos, mesmo que tais anotações tenham sido realizadas há mais de meio século.

A tentativa de localização de prontuários médicos referentes aos tísicos constituiu-se em uma aventura permeada de obstáculos. O local escolhido para o início das investigações sobre a possível existência deste núcleo documental foi a cidade de Campos do Jordão, devido à condição de antiga estação de cura. As visitas aos hospitais e asilos derivados dos sanatórios para tuberculosos e também ao Centro de Saúde do município revelaram que a maior parte da documentação havia sido incinerada, sendo que em apenas dois instantes constatou-se a preservação dos registros procurados.

No primeiro deles, a diretora de uma casa de repouso para 'idosos', após negar a guarda de qualquer documentação sobre o passado do estabelecimento, "lembrouse” de um "arquivo morto" referente ao período sanatorial sem, contudo, permitir a consulta a tais registros, alegando que os consuntivos que por ali passaram eram "gente de elite" e que "não ficava bem” para a atual administração do nosocômio divulgar dados sobre os seus hóspedes, mesmo que a identidade dos doentes fosse preservada sob sigilo.

Em outro sanatório, transformado em abrigo para doentes mentais, soube-se que um ex-diretor clínico da instituição - que também fora tuberculoso - havia transferido para sua residência toda a parcela do arquivo referente às décadas de 30, 40 e 50, impedindo o acesso a pesquisadores.

A frustração gerada pelas infrutíferas consultas aos hospitais jordanenses levou-me a buscar socorro na cidade de São José dos Campos - área que, no passado, também serviu como espaço de concentração de tuberculosos, se bem que menos expressiva que a estância climatoterápica das montanhas. Naquela cidade, a situação revelou-se ainda mais desalentadora, sendo que quase todas as declarações atestavam a total destruição dos registros tisiológicos. O único fio de esperança foi dado por um servidor aposentado do antigo Sanatório Vicentina Aranha, ao lembrar-se que nos últimos anos da década de 60, houve a transferência de grandes lotes de "papéis velhos” daquele hospital para a Santa Casa de Misericórdia de São Paulo, instituição mantenedora do sanatório joseense. 
A permissão de acesso ao Arquivo Central da Santa Casa paulistana ocorreu rapidamente, por meio do apoio prestado pelo Departamento de Medicina Social da Faculdade de Ciências Médicas da própria Santa Casa. De imediato, soube-se que os registros do Sanatório Vicentina Aranha haviam sido destruídos logo após terem chegado a São Paulo, sendo preservados exclusivamente os contratos de trabalho dos funcionários em vias de aposentadoria.

Os dois ‘arquivistas' encarregados do setor (leia-se serventes semi-alfabetizados que, por problemas de saúde, haviam sido deslocados para as tarefas de arquivo), entretanto, informaram que boa parte dos prontuários de um outro sanatório mantido pela Santa Casa - o paulistano São Luiz Gonzaga, também conhecido pelo nome de Sanatório do Jaçanã - ainda resistia ao fogo. E resistia graças ao empenho dos 'arquivistas’ que, contrariando a decisão de uma comissão médica encarregada de selecionar os lotes de registros que deveriam ser anualmente descartados, ocultavam nos labirintos do Arquivo Central um grande número de documentos que haviam sido legados à destruição. Foi assim que boa parte dos prontuários do Hospital-Sanatório São Luiz Gonzaga sobreviveu ao tempo e às condições gerais a que estão abandonados vários arquivos brasileiros.

O razoável estado de conservação do núcleo documental apresentava, em contrapartida, dificuldades materiais para a realização da pesquisa. A ausência até mesmo de cadeira e mesa para a leitura dos prontuários, o acúmulo de poeira, as baixas temperaturas, o mofo do porão transformado em depósito de documentos e a mistura parcial dos registros do sanatório com cerca de um milhão e trezentos mil outros relatórios da Santa Casa determinou que o trabalho padecesse de ritmo excessivamente lento, estendendo-se por cerca de três anos.

Quando já se tinha realizado a localização e fichamento meticuloso de cerca de quatro centenas de prontuários, o Arquivo foi interditado para a pesquisa, sendo declarado como motivo a aposentadoria inesperada dos dois servidores do órgão, vitimados por um mesmo acidente automobilístico. Poucos meses antes, a Irmandade da Santa Casa resolveu construir um novo prédio para abrigar o Arquivo, sendo que, neste recinto, um número significativo de prontuários desapareceu, pois a nova sede do Arquivo Central não só era permeável à chuva como também apresentava vãos na estrutura, condição que tornava livre o ingresso de ‘visitantes' que, à noite, invadiam o local. Devido a estes fatos, a reprodução de alguns trechos das anotações hospitalares incorporadas nas páginas desta pesquisa representam passagens de documentos que, em parte, possivelmente já foram destruídos.

No decorrer da pesquisa no Arquivo Central da Santa Casa, deparou-se com dois tipos de registros. O primeiro deles constitui-se em uma coleção que, mesmo incompleta, alinha cerca de 12 mil fichas referentes aos tuberculosos internados no Hospital São Luiz Gonzaga entre os anos de 1932 e 1968, tempo de vida do nosocômio. Deste total, 3.438 anotações são referentes ao período que se estendeu até o final de 1945, sendo que tais fichas deveriam idealisticamente corresponder ao resumo dos principais dados contidos nos prontuários correspondentes.

O segundo núcleo documental é formado pelos prontuários propriamente ditos, onde encontram-se anotadas as anamneses realizadas pelos médicos, compostas basi- 
camente pelas seguintes informações: a identificação social do paciente, os antecedentes bio-patológicos individual e familiar, os hábitos de vida do doente e o histórico e a sintomatologia da enfermidade a ser tratada. Para além destes dados, os prontuários ainda comportam: o exame físico do pectário, a seqüência de prescrições terapêuticas, a evolução do caso e seu desfecho, sendo possível ainda encontrar, entre as páginas de alguns laudos, os relatórios preparados pelos gabinetes de Raio-X e de odontologia, assim como os dados registrados diariamente pela equipe de enfermagem.

A comparação entre os resumos escritos nas fichas e os conteúdos anotados nos prontuários apresentam constantes divergências, sobretudo no item referente ao desenlace do caso clínico. A multiplicação de situações em que os prontuários alegavam que o paciente havia sido expulso ou se suicidado e as fichas correspondentes retificavam o dado para "alta a pedido" ou "alta clínica” apontam para um possível desvio proposital dos eventos que poderiam colocar em dúvida a imagem piedosa do sanatório religioso.

Apesar dos claros comprometimentos deste núcleo documental e da seleção praticamente aleatória dos prontuários vistoriados, os registros do sanatório paulistano da Santa Casa constituem-se em fonte ímpar de estudo. Segundo diversas comunicações orais prestadas por pesquisadores de diferentes estados do país, além de difícil localização e acesso, os prontuários antigos guardam uma surpresa: as anotações médicas são geralmente avaras em palavras, deixando em branco os itens referentes à anamnese e, freqüentemente, oferecendo informações pouco precisas sobre a terapêutica e o prognóstico do caso analisado.

Contrariando esta tendência, a documentação produzida no âmbito do Sanatório São Luiz Gonzaga mostra-se pródiga em detalhes. Isto porque esta casa de saúde funcionava nos moldes das instituições que hoje recebem a designação de 'hospital-escola', servindo como campo de treinamento dos alunos da Faculdade de Medicina da Universidade de São Paulo e da Escola Paulista de Medicina, aliás, como ocorreu com todo o complexo nosocomial da Santa Casa pelo menos até o final da década de 40, período em que foi inaugurado o Hospital das Clínicas da Faculdade de Medicina da USP.

Preenchidos os prontuários por um ou por vários estagiários, a inexperiência dos medicandos combinava-se com o propósito de clarear o caso, resultando em anamneses extensas e minuciosas, preservando informações pouco usuais nos registros clínicos. Nota-se ainda a constância de anotações colocadas entre aspas ou acompanhadas do alerta "sic", fato que sugere as dificuldades encontradas pelos estudantes e pelos recém-formados em selecionar e 'traduzir' os depoimentos dos pacientes segundo os critérios empregados pelo registro hipocrático.

A riqueza dos dados contidos nas fontes sanatoriais dimensionou os prontuários como importante suporte desta pesquisa, colocando em questão o sentido das informações fornecidas pela série documental. As observações clínicas configuram-se como peças reveladoras da relação médico-paciente, onde o objetivo a ser alcançado compreende a individualização do processo patológico e o efetivo tratamento da enfermidade, tarefas que, para serem cumpridas, exigem um certo grau de desqualificação do paciente como personagem social. Assim, como estratégia de entendimento e intervenção no desequilíbrio orgânico, a medicina compõe registros cuja função é servir como 
material de comunicação privativo dos iniciados nas práticas terapêuticas e, neste encaminhamento, elabora sentenças que, ao fugir da argumentação e da dúvida, parecem a todo o instante querer negar a existência concreta do ser humano como 'adoentado' (Clavreul, 1983).

O caráter ritualístico da relação médico-paciente confere um sentido peculiar a este tipo de registro. O peso das imagens mútuas nutridas pelo clínico e pelo enfermo faz com que cada um deles saiba aprioristicamente o que pode ou não ser dito, bem como o que deve ser anotado na papeleta hospitalar. O prontuário constitui-se, então, formalmente, em um instrumento moldado pela ordem médica e pelo poder institucional, em que a espontaneidade da fala e da escrita estaria comprometida pelas mediações inerentes às circunstâncias, sendo esta dimensão assunto de várias análises teóricas (Britto, 1988).

Ciente dos debates em torno da especificidade e dos limites da documentação nosocomial, mesmo assim acredita-se que os prontuários elaborados pelo setor de tisiologia da Santa Casa abrem perspectivas únicas em que a história clínica se entrelaça com a trajetória existencial do doente, assim como ganha expressão a capacidade intervencionista da medicina e as reações dos clínicos em face da sucessão de relatos tristes, confidenciados pelos seus pacientes. Com isto, os prontuários revelam-se peças fundamentais para a composição de uma história social que busca abarcar as várias facetas do dilema humano orquestrado pela Peste Branca.

Para completar a soma das fontes utilizadas, buscou-se colher alguns depoimentos orais de personagens que viveram o drama sanitário, quer na condição de 'fraco do peito', quer no papel de indivíduos próximos dos infectados. Constituindo recurso importante para a realização da pesquisa, as vozes colocadas neste texto mostraram-se reticentes em prestar informações mais detalhadas e, quando o fizeram, cobraram sigilo absoluto sobre suas identidades, sendo que alguns revelaram-se desejosos de serem nomeados por meio de pseudônimos por eles próprios escolhidos. Mesmo assim, salienta-se que tais informações resultaram da espontaneidade dos depoentes, cabendo a eles narrarem o que achavam 'importante' ser confidenciado, havendo pouca interferência do pesquisador. Assim, distancia-se dos métodos específicos e das intrincadas técnicas empregadas pela História Oral.

A pluralidade de fontes exigiu que fosse dado um recorte temático às questões encontradas. Metodologicamente, foi apurando a diversidade temática que se buscou qualificar cada tipo de documento. Porque entende-se que a verdade não está nos documentos, procurou-se a confrontação, a soma e o contraste como alternativas prudentes para o exame.

Outros recursos foram usados para diversas fontes. No caso da Literatura, por exemplo, houve empenho em evidenciar a seqüência evolutiva do 'clima de tragédia'. Neste encaminhamento, aliás, cabe salientar a universalização das vozes. Como em outros circuitos literários, o Brasil integrou o conjunto da produção sobre a tuberculose e isto basta para sugerir reflexões sobre a coerência entre o nosso contexto e os demais.

A nacionalização da problemática da Peste Branca, contudo, mereceu cuidados. Foi por tal atenção que se recorreu à leitura dos textos dos sanitaristas nacionais. Na mesma linha, a voz dos 'esquecidos', pobres doentes, pessoas anônimas, também foi 
recolhida. A formulação de um saber leigo sobre a doença e os doentes, combinada com as formas elaboradas de intervenção sanitária foram enquadradas nos processos de institucionalização do país. Assim, aspectos do 'público' e do 'privado', se combinaram gerando comportamentos do doente em face do Estado, da sociedade e de si próprio.

O enfoque do pretérito das doenças e dos doentes ainda é uma operação aceita reticentemente pelos historiadores. A disseminação do pressuposto segundo o qual as patologias constituem-se em eventos de exclusivo entendimento das Ciências Médicas teve como conseqüência a percepção de que o convívio íntimo com a enfermidade concretiza-se como experiência individual e única, portanto, de difícil análise pelos historiadores. Como resultado, durante um longo período, as Ciências Humanas acomodaram-se em atribuir ao clínico humanista a tarefa de estudo dos eventos ocorridos no passado e motivados pelos processos biológicos.

Neste contexto, a área genericamente denominada de História da Medicina acabou sendo ocupada predominantemente por pesquisas realizadas em torno de alguns poucos eixos temáticos, principalmente os orientados para a averiguação das 'idéias antigas' sobre as enfermidades e os remédios, das instituições médicas e das biografias dos clínicos e cirurgiões de destaque, assim como pelas abordagens gerais que inevitavelmente convergiam para os conceitos de 'evolução' e 'progresso' do arsenal curativo e preventivo. Neste último tópico, encontram-se constantes observações acerca das devastações provocadas pelas epidemias, sendo que as reações sociais frente aos desastres pestíferos têm sido registradas como ilustrações da precariedade dos recursos sanitários no tempo pretérito e, em alguns momentos, da ingenuidade do espírito humano.

O direcionamento assumido por esta vertente de análise do passado da 'arte de curar' prima por anunciar a medicina como uma área sintonizada com as necessidades sociais, mas ao mesmo tempo 'neutra' e autônoma para compor seu campo de conhecimento e sua esfera de atuação. A ótica tendencialmente internalista que instrui a História da Medicina resulta no quase total desvinculamento entre a doença e o doente, pois, enquanto os processos patológicos foram reconhecidos como eventos passíveis de alterações no tempo, o Homem enfermo foi, de regra, desqualificado como personagem histórico, dando repercussão ao preceito antigo - mas ainda em voga - segundo o qual a medicina resume-se ao 'encontro de uma técnica científica e de um corpo'.

A cirurgia acadêmica que isolou as patologias dos seres humanos diretamente atingidos pelas enfermidades permitiu o florescimento da linha de estudo que situa o morbus e seus pesquisadores como personagens exclusivos de interesses. De Hans Zinsser a McNair Wilson, na primeira metade do século passado, até Michel Foucault, Robert Gottfried e François Delaporte, em datas mais recentes, a História da Medicina e suas ramificações produziu textos que, variáveis na metodologia e na documentação, afastaram-se do compromisso de registrar os dilemas experimentados pelos agrupamentos abatidos pelas doenças.

O pouco de atenção que o enfermo recebe ocorre quando, relegado à condição de paciente clínico, os historiadores o relacionam aos momentos exaltativos das descobertas científicas ou quando torna-se necessário exemplificar as supostas alterações morais produzidas pelo estado enfermiço. A possibilidade mais corriqueira que favorece a individualização do ‘debilitado’ está ligada às situações onde ele é registrado como 
o primeiro ser humano a receber o benefício de uma nova droga ou técnica desenvolvida pela medicina, sendo exemplar a consagração dos nomes dos meninos James Phipps e Joseph Meister, pelo fato de terem sido as primeiras pessoas vacinadas, respectivamente, contra a varíola e contra a raiva.

Caso diferente é protagonizado por uma Old Lady britânica que garantiu lugar nas páginas médicas como exemplo da 'paciente leviana', pois diariamente percorria os hospitais londrinos em busca de remédios gratuitos para tratar de várias moléstias que a importunavam, utilizando as drogas, porém, para dar sabor especial aos pastéis que ela própria vendia em praça pública.

Menções como estas ganham formatos novos quando o doente avaliado constitui-se em personagem de projeção social. Nestes casos, os distúrbios patológicos aparecem como fenômenos definidores da identidade e das ações dos enfermos, sendo que coube ao Dr. Cabanès instituir o 'gabinete secreto da história', consultório literário no qual desfilaram os principais nomes da política e da cultura européia moderna. Segundo as conclusões do Dr. Cabanès (1937), os adoentados sucumbiam frente ao gigantismo da doença, situando a anafrodisia de Luis XIV, a epilepsia de Luis XV e a úlcera estomacal de Napoleão, dentre outros possíveis desarranjos orgânicos e psíquicos, como os verdadeiros motores da História mundial.

A localização do Homem com a saúde debilitada como personagem de expressividade histórica mais ampla manteve-se como proposta de uma minoria de pesquisadores, dentre eles o clínico alemão Henry Sigerist. Na posição de diretor do Instituto de História da Medicina da Universidade de Leipzig, coube ao Dr. Sigerist, ainda no final dos anos 20, abrir novas perspectivas de análise, sugerindo a necessidade de conjugar as doenças aos seus tributários, enfatizando ainda a carência de pesquisas voltadas para o estudo da construção simbólica das enfermidades e da reação dos doentes frente à estigmatização (Sigerist, 1932).

No início da década de 30, a transferência do Dr. Sigerist e de alguns de seus principais auxiliares para a Johns Hopkins University, permitiu que florescesse na América do Norte um atuante centro de pesquisas de História da Medicina. Aglutinados em torno dos princípios aparentados do marxismo, pesquisadores do porte de Erwin Ackerknecht, Bernhard Stern e George Rosen - além do próprio Henry Sigerist - incentivaram a diversificação dos temas sob análise, resultando em inovadoras perspectivas para o entendimento dos fenômenos patológicos e da intervenção médica, segundo o gradiente fornecido pela organização classista da sociedade.

A multiplicação dos estudos sobre as enfermidades e também sobre as condições de vida dos agrupamentos humanos e os vínculos entre a ação médica, a política e a economia determinou que a proposta sigeristiana de análise da experiência individual com a enfermidade fosse momentaneamente preterida. No ano de 1943, novamente o Dr. Sigerist voltou a se interessar pelo tópico, mas, surpreendentemente, aproximou a identificação dos doentes da vertente assumida pela sociologia neopositivista, representada sobretudo pelos ensinamentos de Talcott Parsons.

Tomando como exemplo os tuberculosos, o clínico alemão anunciou os pectários como vítimas da pobreza material que conduzia à infecção pulmonar mas, ao mesmo tempo, generalizou todos os enfermos como indivíduos que se deixaram adoecer para 
assumirem um novo 'papel social' e, com isso, fugirem das obrigações cobradas da parcela sadia da população. Em continuidade, os Homens com a saúde abalada foram indicados como personagens perniciosos e carentes de pronta reeducação moral.

Apesar deste posicionamento, o próprio professor Sigerist (1987) reiterou, nos anos 50, a necessidade de elaboração de uma História da Medicina 'sob a ótica do paciente', declaração que recebeu severas críticas porque considerada como sugestão desarrazoada. Herdeiro intelectual de Henry Sigerist, George Rosen (1967) retomou a mesma proposta na década seguinte, convocando os historiadores profissionais para colaborarem nas pesquisas centradas na problemática sanitária.

Uma das primeiras cartas orientadora da participação dos historiadores na análise dos eventos instruídos pela enfermidade deveu-se à pesquisadora francesa Elizabeth Carpentier (1962). Apoiada nos núcleos documentais produzidos em torno das epidemias que assolaram a Europa e parte da Ásia no decorrer do século XIV, esta autora tematizou a quadra pestífera em várias subáreas de estudo, enfatizando a necessidade de inquirições sobre o poder médico, a reação do Estado frente às crises sanitárias e a diversidade dos comportamentos coletivos. Posicionamento semelhante impregnou os seguidores da New Social History (Grob, 1977), que indicaram como setores carentes de estudos os processos patológicos, os padrões de mortalidade e morbidade, as conseqüências institucionais das crises epidêmicas e também os papéis desempenhados pela medicina no contexto da modernização do tecido coletivo.

Paralelamente a isto, alguns pesquisadores buscaram estabelecer as possibilidades teóricas de enquadramento do doente no contexto histórico. O norte-americano William McNeill (1976) situou os agrupamentos infectados como 'macróbios' que não souberam se esquivar da ação patológica dos micróbios, conferindo um caráter biologizante a uma possível história dos enfermos. O francês Jacques Léonard (1981), por seu turno, classificou o estudo do pretérito dos doentes como uma ramificação da 'história dos vencidos', reiterando o caráter passivo e acomodado dos doentes no contexto social.

Deve-se ao médico e pesquisador espanhol Pedro Laín Entralgo (1969, 1983, 1984) uma das mais persistentes tentativas de interpretação histórica dos personagens adoentados. Autor de numerosos livros que incorporaram o enfermo na condição de paciente da clínica, Laín Entralgo tem se proposto a retraçar a trajetória deste grupo na tela das relações sociais engendradas entre os médicos e sua clientela. Avizinhando-se do idealismo neokantiano, este estudioso tem apoiado suas análises nas fontes consagradoras dos compromissos éticos que unem os personagens aproximados pela condição doentia, resultando em versões caricaturais da 'realidade do ser', isto porque frutos de enfoques distanciados das conjunturas históricas específicas.

As dificuldades de diálogo com os ‘tipos’ carentes de saúde exigiu que pesquisadores contornassem suas limitações por meio da exploração de tópicos correlatos à existência enferma. Além dos estudos clínico-epidemiológicos e dos ensaios quantitativistas elaborados pela Demografia e pela Sociologia, o congraçamento celebrado nas últimas décadas entre a História e a Antropologia permitiu que, seguindo as pegadas de Marcel Mauss e Mary Douglas, aflorasse uma gama de estudos sobre o corpo como substitutivo parcial das análises englobadoras das enfermidades e dos 
enfermos. Adotado pela Nouvelle Histoire, tal encaminhamento tende a simplificar demasiadamente a convivência íntima com a enfermidade, sendo significativo que um dos primeiros textos a propor esta vertente de pesquisa ostente o seguinte título: "O corpo: o homem doente e sua história” (Revel, 1976, 1978).

As pesquisas instruídas pela tísica e pelos pectários refletem integralmente as limitações desta área do conhecimento. Assinalada insistentemente nas histórias gerais da medicina e nos ensaios monográficos, a Peste Branca e seus desdobramentos têm sido objeto de extenso tratamento descritivo, havendo entretanto pouca atenção dos pesquisadores acerca da reação dos tuberculosos frente à enfermidade, inclusive porque durante as últimas décadas e até o advento da Aids, a tísica foi considerada como ‘doença dos países pobres' e, por contraste, ameaça ‘sob controle’ nas sociedades mais abastadas.

Neste contexto, apenas os relatórios orientados por Roland Barthes e enfeixados no livro Histoires de la Tuberculose buscaram conceder algum destaque às memórias e recordações dos doentes do peito que ganharam projeção social, havendo em anexo uma copiosa lista composta pelos nomes de 'tísicos ilustres', tendência herdada da produção acadêmica anterior. Apesar da proposta inovadora, esta obra define-se mais pelo empenho de suas autoras em conceder oportunidade de expressão aos agrupamentos médicos, limitando o espaço para os pronunciamentos daqueles que foram supliciados pela intimidade forçada com a moléstia kochiana (Grellet, 1983).

Um balanço sobre a historiografia européia e norte-americana permitiu ao historiador Jacques Le Goff e ao médico Jean-Charles Sournia (1985) declararem, sem qualquer dificuldade, que as ‘doenças têm uma história’, observando o recente acúmulo de pesquisas sobre o tema.

Em contraposição, as sociólogas Claudine Herzlich e Janine Pierret (1984) alertaram sobre a existência de uma história da medicina desumanizada, registrando a ausência de estudos com base na trajetória de vida dos indivíduos e dos grupos assolados pelas enfermidades. No final das verificações sobre a historiografia estrangeira, parece irônico afirmar que os pesquisadores já produziram inclusive excelentes histórias dos cadáveres, sem contudo ainda atentarem para a necessidade de estudos centrados nas vidas dos adoentados.

Refletindo a tendência internacional, a História e as Ciências Sociais brasileiras mostraram-se reticentes em assumir a temática da doença e dos doentes. Neste contexto, destaca-se a dissertação de mestrado em Ciências Sociais do sociólogo Oracy Nogueira (1945) e consideravelmente revista na publicação datada de 1950 que, versando sobre a experiência grupal com a tuberculose, permaneceu como exceção acadêmica por um longo período. Explorado na minha pesquisa tanto como obra de referência quanto como fonte primária, o texto do professor Nogueira ganha dimensão histórica própria, tornando-se indispensável para o conhecimento das vítimas da Peste Branca no período anterior ao advento da estreptomicina.

Em anos mais recentes, algumas tentativas foram levadas a cabo no sentido de recuperar o condicionamento social da existência tísica. A pesquisadora Alice Marques (1983) buscou verificar a eficiência dos canais de comunicação entre os assistentes sociais e os pectários, ambientando seu trabalho em uma unidade hospitalar espe- 
cializada, sem contudo orientar seu estudo para a análise dos pectários no cenário social mais amplo.

Ao mesmo tempo, o epidemiologista Antonio Ruffino Netto e o sociólogo José Carlos Pereira $(1981 ; 1985)$ buscaram contextualizar a existência dos doentes do peito, definindo genericamente o tuberculoso como 'um Homem histórico, concreto, que preenche um lugar no tempo e no espaço’, concepção articulada ao entendimento da saúde e da doença como fenômenos explicados pelas 'relações globais' ao nível da 'realidade social concreta'. Infelizmente, estes autores apenas sinalizaram as possibilidades de tratamento histórico dos pectários, desviando suas análises para o campo de 'determinação social' da Peste Branca.

Neste contexto, destaca-se o importante estudo realizado pela pesquisadora Ângela Pôrto (1997) sobre as repercussões da tuberculose na trajetória pessoal e profissional do poeta Manuel Bandeira. Seguindo as trilhas abertas pela recente História Social, esta estudiosa lançou novas luzes sobre as relações possíveis entre doença, trajetória individual e sociedade, aflorando como iniciativa original assinada por uma profissional da História.

O quase silêncio dos historiadores acerca dos doentes não é um fenômeno isolado. Compartilhado por outras áreas científicas e até mesmo por uma ampla parcela da comunidade hipocrática, as questões sociais e sobretudo os dilemas existenciais suscitados pelos agrupamentos de enfermos parecem receber respostas furtivas, revelando as dificuldades de incorporação dos adoentados tanto nos debates acadêmicos quanto nas discussões administrativas e de políticas públicas.

Em conseqüência, ainda são recentes e lacunares as tentativas de conferir direitos específicos aos indivíduos com a saúde abalada, inclusive o privilégio de conhecer em detalhes as alternativas terapêuticas apropriadas para o seu caso e os riscos inerentes às opções selecionadas pela medicina. De regra, tudo ocorre como se o paciente fosse privado de discernimento próprio, cabendo ao médico e a um 'responsável' pelo doente a tarefa de resolver as questões suscitadas pela enfermidade. Assim, a apatia dos historiadores revela-se como uma das facetas do isolamento social a que são relegados os grupos tocados pelos desarranjos de fundo orgânico e/ou psíquico.

A ausência de análises que situam a Peste Branca e suas vítimas como elementos de uma mesma problemática histórica, no tocante ao contexto brasileiro, produz a sensação de que tudo ainda está por ser feito. Por isso, antes de focar os personagens consuntivos, impõe-se a necessidade de fixar o cenário. Cenário que se torna fundamental para a compreensão das atitudes individuais e coletivas frente ao dilema sanitário. Com isso, a pesquisa ganha sentido e extensão bem mais abrangentes que o inicialmente programado, permitindo o enquadramento da História Social da Doença e do Doente na ampla teia do pretérito nacional.

Assim, tomando-se como opção o enquadramento dos doentes como ativos participantes da vida cotidiana, advoga-se que a luta contra a doença que mina o organismo encontra continuidade nas respostas individuais e coletivas frente ao isolamento e à estigmatização. Seguindo esta linha de entendimento, a História Social da Tuberculose e do Tuberculoso ganha novos ramais, fluindo para o estudo das reações produzidas pelos impulsos estigmatizadores. Reações estas que não obede- 
cem sentido único, seguindo caminhos múltiplos e contrastantes que, no final, mostravam-se como estratégias para ressaltar a própria condição humana que muitas vezes era negada aos pectários.

As lacunas deixadas pela historiografia mostram-se flagrantes para os estudiosos da doença e dos doentes. Desafios permanecem, mas, sem dúvida, os caminhos estão dispostos. Seguindo esse pressuposto, desenvolveu-se este livro. Nele conta-se um pouco da história da tuberculose, dos fracos do peito e também da sociedade brasileira. Sob tal égide, o autor se colocou como um atento ouvinte dos personagens aproximados pela tísica, compartilhando os medos, as esperanças de todos e sobretudo o desespero de uma legião de infectados que lutava contra a decretação da morte social, bem antes da visita do Ceifeiro Implacável. 


\section{Parte I}

\section{IDÉIAS E CONTROvÉRsIAS}

Todo médico, seja ou não clínico, seja ou não funcionário público, deve colaborar, da melhor maneira possível, no que se refere à manutenção da saúde pública, e ser um propagandista sincero de todas as medidas de higiene individual e coletiva que visem o bem comum.

Código de Deontologia Médica (1931) 
Nenhuma outra patologia incitou tanto os estudiosos - médicos, juristas, administradores públicos, religiosos, escritores de ficção e pesquisadores em geral - quanto a tuberculose. Enfermidade mortal que só no século XX foi responsabilizada por cerca de um bilhão de mortes, a tísica favoreceu, na linha histórica, a elaboração de um campo conceitual próprio que, estendido aos seus tributários, promoveu sucessivos conflitos de perspectivas e interesses, resultando no mosaico de interpretações sobre a doença e o doente. 


\section{1}

\section{A Medicina e o Fato Tuberculoso}

A tuberculose é uma doença infecto-contagiosa que, de regra, assume evolução crônica e tem como agente etiológico a Mycobacterium tuberculosis. Acredita-se que este micróbio - também conhecido como bacilo de Koch - seja anterior ao próprio Homem, sucedendo formas ainda mais elementares de vida microscópica. O encontro entre o germe da tuberculose e a espécie humana levou o agente infeccioso a desenvolver estratégias de adaptação ao novo hospedeiro: além da perda da capacidade de multiplicação no meio exterior, o bacilo inicialmente sofreu um significativo aumento de virulência para, na continuidade, restringir sua capacidade destrutiva, tornando-se um comensal aceitável para os indivíduos e para os agrupamentos humanos.

Nessas condições, o micróbio da tísica encontrou nos pulmões do ser humano um microecossistema favorável à sua sobrevivência, ganhando possibilidade de reprodução em um ambiente ao mesmo tempo quente e úmido, arejado e sombrio. Com a proliferação bacilar em forma de colônias, parte das sementes usualmente migram para outras regiões do aparelho respiratório, podendo se disseminar por todo o organismo contaminado por meio das vias broncogênica, linfática e hematogênica. Outra parcela dos germes é expulsa pelas vias aéreas, poluindo o meio ambiente.

No prazo de 24 horas um indivíduo infectado pode expelir até 3,5 milhões de bacilos da tuberculose, muitos deles presentes em gotículas microscópicas que são eliminadas através da tosse, do espirro ou no processo da fala. Estas minúsculas partículas podem flutuar por um período de até 8 horas, depositando-se em roupas, lenços, livros, móveis e na poeira. Eventualmente, as menores gotículas podem ser aspiradas por outros indivíduos, sendo que se não forem retidas pelas mucosas do nariz e da garganta, o material pode atingir os bronquíolos respiratórios e os alvéolos, tornandose substância infectante. Outra via comum de contágio em décadas passadas constituía-se na ingestão de leite e de carne bovina comprometidas pela Mycobacterium bovis, bacilo similar ao $M$. tuberculosis e que também pode causar a tísica.

Instalando-se no organismo humano sadio, o bacilo de Koch permanece inativo por cerca de três dias. A partir deste momento inicia-se o ciclo de reprodução que se renova a cada 18 horas, média bem superior à de outras variedades microbianas. Também neste período é ativado o processo de defesa orgânica, primeiramente como resposta imunitária inespecífica e logo depois por meio de reações imunológicas específicas, mediante a ampliação da capacidade de fagocitose das células mobilizadas contra o elemento invasor. 
Neste encaminhamento, o foco primário da infecção geralmente produz uma lesão inflamatória inicial, localizada na região subpleural. Entre a terceira e a oitava semanas, os bacilos já formaram colônia capaz de produzir reação inflamatória elementar, evidenciando a existência de um processo destrutivo dos tecidos pulmonares. A resposta orgânica permite que as células histiocitárias e linfócitas recubram a lesão, possibilitando a constituição de um nódulo ou tubérculo específico. Os bacilos, entretanto, se propagam por intermédio da via linfática para os gânglios adjacentes, dando conformidade ao chamado ‘complexo primário’.

Estabelecida a primoinfecção, a continuidade da doença permanece incerta, podendo evoluir para uma tuberculose crônica ou, mais raramente, para a tísica progressiva aguda. A infecção, contudo, pode permanecer estacionária, abrindo chances para que os bacilos latentes reiniciem sua ação destrutiva anos após o evento inicial. A espécie humana, entretanto, apresenta significativa resistência contra esta agressão, sendo que o desenlace mais freqüente constitui-se na regressão do processo patológico e a cura espontânea, com a conseqüente recuperação, cicatrização ou calcificação do tecido danificado pelo agente etiológico da chamada Peste Branca.

Os fatores que determinam o curso assumido pela infecção ainda não são suficientemente conhecidos. A linha de entendimento que busca situar as condições materiais de vida como explicadoras do prosseguimento (ou da interrupção) do processo tísico parece não responder sozinha ao enigma, sendo que cada vez mais apontam-se para as respostas relacionadas com a carga genética como fator de proteção individual.

O quadro clínico apresentado pela tuberculose é extremamente complexo, advogando-se que esta patologia é 'a mais caprichosa de todas as doenças', dado a multiplicidade de sintomas que podem confundir o diagnóstico médico. Na fase inicial, a infecção apresenta-se quase sempre silenciosa, ou com manifestações discretíssimas, difíceis de serem detectadas pelo Raio X.

A evolução do processo mórbido geralmente tende a produzir febre que, à tarde, pode chegar a 39 graus centígrados, acompanhada de suores, emagrecimento contínuo e acentuado, dores torácicas, tosse, expectoração crescente, cansaço e dificuldade de respiração. Por fim, a hemoptise evidencia o estado enfermiço, principalmente quando associada aos demais sintomas. O diagnóstico definitivo encontra apoio na radiografia pulmonar, na tomografia, na análise laboratorial do esputo e na prova tuberculínica.

\section{Enigma da Enfermidade}

As definições atuais que permitem a compreensão clínica-epidemiológica da tísica são fruto de uma história marcada pela paixão e pela necessidade. Paixão porque a persistência do enigma patológico se impôs como desafio que exigia respostas clareadoras e, em conseqüência, o pretérito da medicina está repleto de interpretações sobre os mecanismos da doença do peito e as possíveis decisões terapêuticas. A necessidade de soluções eficientes para conter a disseminação da moléstia deve-se ao fato de a tísica se constituir em uma das maiores ceifadoras de populações, pois, apesar 
da resistência humana ao bacilo, o 'mal consuntivo' mantém-se em estado endêmico através de gerações, comprometendo assim sucessivas sociedades.

A comunidade médica, chamando a si a tarefa de decifrar o mistério, invariavelmente encontrou nos debates sobre a doença do peito motivos suficientes para discórdia, resultando em impasses que favoreceram a quebra da regra incentivadora da harmonia entre os discípulos de Hipócrates. A série de respostas oferecidas ao desafio da moléstia pulmonar colocou em confronto variadas linhas explicativas, aproximando magia e religião, medicina oficial e tradições populares que, no final, anunciavam menos a positividade do saber que a complexidade da doença que insiste em ocultar alguns de seus mecanismos de funcionamento.

Infecção tão antiga quanto a humanidade, é provável que os primeiros humanídeos já padecessem com a tísica, mesmo que a existência de pequenos grupos isolados inibisse a difusão maciça da moléstia. Com a ocorrência da Revolução do Neolítico, os agrupamentos humanos cresceram em número e a domesticação de algumas espécies animais ampliou as possibilidades de contágio.

Apesar da precariedade de informações acerca da tuberculose no período anterior ao momento hipocrático, sabe-se que a doença esteve presente entre os egípcios, encontrando-se indícios do Mal de Pott em partes de corpos mumificados e com data aproximada de 6.000 anos. Aventa-se mesmo a hipótese de que, no último milênio antes de Cristo, teria existido uma espécie de sanatório na região do delta do rio Nilo. Esta suposição, anotada em diversos relatórios arqueológicos, encontra apoio na identificação de restos de múmias infectadas, concentrados espacialmente nos terrenos escavados (Dubos, 1952).

A disseminação da moléstia fez com que, tanto no Egito quanto na Índia, surgissem registros que cobravam prudência redobrada aos 'médicos' no tratamento das vítimas da Peste Branca. Para não afetar a reputação da linhagem de curandeiros, aconselhava-se que os responsáveis pela assistência aos doentes atendessem apenas os infectados que se encontrassem nas fases iniciais da enfermidade, advertindo-se que os pectários em estágio avançado deveriam ser evitados, já que a morte do paciente era considerada como desenlace certo.

Apesar do empenho de vários povos da Antigüidade Oriental em ampliar o conhecimento sobre a tísica, coube aos gregos a descrição mais apurada da doença do peito, sendo que os textos atribuídos a Hipócrates constituem-se no melhor repertório de informações sobre o assunto. Fruto de uma 'escola médica' que buscava antes de mais nada registrar as observações sobre os fenômenos da natureza, os escritos ligados ao nome do Mestre de Cós foram os que com maior minuciosidade entenderam a patologia dos pulmões, afastando-a do domínio exclusivo dos princípios religiosos e definindo-a como 'a mais difícil de curar e a mais fatal' das doenças conhecidas no período.

Os termos ‘consunção’ e ‘tísica’ - importados da Índia, significam emagrecimento ou depauperação do corpo -, além da categoria 'fimata', foram compreendidos pela academia hipocrática como sinônimos de ulceração ou supuração dos pulmões. A doença era explicada como conseqüência de três outras patologias orgânicas: a pleurite purulenta, a hemoptise e, por fim, a pneumonia, quando esta tomava um curso diferente do habitual. 
Apesar dos gregos confundirem a tuberculose com outras expressões patológicas que afetavam o aparelho respiratório, as anotações hipocráticas estabeleceram os fundamentos do raciocínio clínico sobre a tísica. Estes princípios persistiram, quase inalterados, até o advento dos tempos modernos, confirmando o grau de sofisticação alcançado pela medicina da Antigüidade.

No Capítulo XI do Livro Primeiro atribuído a Hipócrates, observa-se, por exemplo, um instante significativo da descrição grega sobre a doença pulmonar. Neste texto, as causas apontadas para a ocorrência da tísica consistem sobretudo quando, na ocorrência da pneumonia, o doente não elimina catarro que, permanecendo no pulmão, torna-se matéria pútrida e deletéria, sufocando o paciente e comprometendo o funcionamento de todo o organismo (1911:198).

Na seqüência de seus escritos, o esculápio buscou agregar novos elementos às suas observações, sem no entanto transformar o esquema inicial proposto. No Capítulo XII do mesmo Livro, Hipócrates acrescentou que o muco produzido pelo enfermo pode eventualmente descer do nariz e da laringe, atingir os pulmões e também impregnar outras regiões do tórax, inclusive o estômago. A tosse que se inicia fraca, paulatinamente ganharia intensidade, acompanhada de febre prolongada e a parcela eliminada do catarro mostrar-se-ia densa e pútrida. O apetite desapareceria e o doente viria a morrer em conseqüência do pulmão ter se tornado inteiramente deteriorado ou ainda devido aos distúrbios digestivos que, acreditava-se, era marca definidora da tuberculose terminal.

O processo mórbido comandado pela tísica poderia levar inclusive à ruptura de uma veia, anunciada pelo aparecimento de laivos sangüíneos no esputo. Tanto quanto o catarro, parte do sangue alojar-se-ia nos pulmões, contribuindo para a putrefação do mesmo. Nesta situação, Hipócrates advertiu que o doente deveria buscar socorro médico e permanecer de cama por longos períodos. Caso não o fizesse, a quantidade de sangue perdido comprometeria a vida do enfermo que tornar-se-ia emaciado e a sua cabeça “diminuiria de tamanho" (1911:198), chegando a óbito em decorrência da debilidade orgânica causada pela escassez de sangue no organismo.

A partir dessas constatações, os médicos gregos estabeleceram como sintomatologia básica da consunção a existência de sons anormais produzidos no peito, dor torácica intensa, tosse freqüente, escarro grosso e purulento, respiração trabalhosa, rouquidão da voz, rubor facial e 'empelotamento da língua'. Acrescentaram ainda que o inchamento dos pés e joelhos, a profusão de suores, as unhas curvas e a diarréia intensa constituíam-se em sinais indicativos da proximidade da morte para o doente do peito.

A medicina romana pouco acrescentou às propostas gregas. Ao contrário, acredita-se que, tentando simplificar o entendimento sobre a patologia, os latinos distorceram os ensinamentos hipocráticos. Nesta situação destacou-se o esculápio Galeno que, buscando explicações para a tísica, concluiu que a 'úlcera pulmonar' era produzida por meios mecânicos ou traumáticos que resultavam na laceração do tecido dos pulmões. O ferimento dava origem a uma inflamação que, se não curada em poucos dias, configurava-se como uma tísica. 
A multiplicidade das discussões sobre a etiologia da tuberculose na parte final da Antigüidade pareava com a variedade de propostas terapêuticas existentes. Nos escritos de Plínio, o Jovem, foram arrolados os principais remédios empregados pelos greco-romanos contra a tísica, sabendo-se que para a cura da tosse era recomendada a ingestão de pulmão de lobo cozido em vinho, acompanhado de uma bebida composta de bile de urso, saliva de cavalo e mel.

Para os enfermos que produziam escarro sangüíneo, indicava-se carne de lebre e de caracol e a combinação de pó de chifre de cervo e um pouco de terra da ilha de Samos diluídos em vinho de murta. O leite, especialmente o de origem bovina, complementava qualquer prescrição medicamentosa, estando presente em todas recomendações clínicas, desde as primeiras observações registradas sobre a mortal enfermidade (Castiglioni, 1933).

Oferecendo complemento a estas terapêuticas, os médicos gregos e romanos prescreviam ainda a aplicação de bálsamos elaborados com substâncias extraídas do pinho e da mirra e também chás de vegetais considerados específicos para os doentes do peito, como licorice, violeta, hissopo e pulmonária. Além disso, alguns derivados minerais ganharam créditos curativos, destacando-se, entre outros, o arsênico e o enxofre, aconselhando-se também a recorrência a eméticos e purgativos e a prática continuada de sangrias.

Ainda no tempo de Plínio, o tratamento dos pectários encontrava como regra geral o apelo à climatoterapia. Na Roma Imperial, por exemplo, era comum o envio dos tuberculosos para regiões caracterizadas pelo clima quente e seco, especialmente a Sicília e o Egito, medida que era geralmente combinada com viagens marítimas que demandavam longo período de tempo. Atendendo a estes princípios, Cícero partiu gravemente enfermo de Roma, permanecendo dois anos em excursão que o levou até o continente asiático. De regresso à capital do Império, o orador e político apresentou-se curado, fazendo alarde das qualidades terapêuticas das peregrinações para o Oriente.

No período medieval, as idéias e o receituário greco-latinos ganharam a dimensão de verdades sacramentadas, cabendo especialmente aos árabes as contribuições acerca da descrição do aparelho respiratório, inclusive sobre a circulação sangüínea nos 'vasos pulmonares'. Além disso, os muçulmanos trouxeram para a Europa os conhecimentos médicos produzidos na Índia, na Síria e na Pérsia, oferecendo descrições detalhadas sobre a tuberculose intestinal, fato que, como vários outros ensinamentos, passou despercebido pela maior parte dos esculápios cristãos.

Paralelamente à tradição hipocrática, as concepções religiosas cristãs ganharam peso, ensinando que as moléstias eram produto da vontade divina, fato que permitiu que as enfermidades, inclusive a tísica, fossem objetos de curas milagrosas. $\mathrm{O}$ 'mal das escrófulas' - mais tarde identificado como adenite tuberculosa - contou durante séculos com o simples toque das mãos reais como principal forma de cura, ganhando popularidade na França e na Inglaterra. A persistência da tradição desde o tempo do rei Clóvis até o século XVIII chamou a atenção dos historiadores, sendo que Marc Bloch (1983) foi o pioneiro em reconhecer o caráter simbólico imputado à enfermidade e aos 'reis taumaturgos'. 
No contexto da Baixa Idade Média, a Escola de Salerno tornou-se responsável pela renovação do ensino e da prática médica européia, sendo que o ecletismo das idéias assumidas por esta Escola trouxe limitadas novidades sobre o problema representado pela tísica. Mesmo assim, coube aos salernitanos adotarem alguns ensinamentos das clínicas muçulmana e judaica, que até então tinham sido rejeitados pelos europeus, tais como a dieta centrada no leite humano e alguns itens da flora oriental, inclusive narcóticos para aliviar os padecimentos dos fimatosos mais graves. Em um texto produzido em Salerno e datado dos últimos séculos medievais, pouco foi discutido sobre a doença consuntiva, repetindo-se praticamente as prescrições legadas da Antigüidade Clássica, intercalando-as com as propostas terapêuticas assumidas pelos judeus e pelos árabes (Regola, 1975).

Um dos motivos possíveis para a explicação do escasso interesse pela tuberculose demonstrado durante a Idade Média deve-se ao fato de ter ocorrido, naquela época, um retrocesso quantitativo de casos de consunção, conseqüente ao declínio da vida urbana na Europa. Entretanto, a partir do século XV, a tísica novamente se mostrou alarmante, disseminando-se entre os povos europeus. A interpretação segundo a qual o fenômeno deveu-se exclusivamente ao ‘renascimento' das cidades parece não convencer os estudiosos, que preferem conjugar o incremento do número dos pectários com a diminuição da comunidade de hansenianos no contexto europeu.

O fato da tuberculose e da lepra terem como agentes etiológicos micróbios que pertencem ao mesmo gênero biológico permite a suposição de que ambas as micobactérias estabeleceram uma relação antagonística pela competição imunológica. Em outras palavras, advoga-se que a infecção tuberculosa inibe a ocorrência da hanseníase, fenômeno que explicaria a alteração do perfil epidemiológico europeu, ocorrida nos momentos derradeiros da Idade Média, quando coincidiu o aumento de casos de tísica com o decréscimo da colônia dos leprosos (Grmek, 1983).

Contra tal hipótese, alguns elementos foram reunidos, incluindo referências medievais sobre indivíduos portadores de ambas as moléstias e também a existência de uma forma intermediária das patologias, denominada lepra tuberculóide, e restrita à epiderme humana. Alguns pesquisadores acrescentam ainda que a involução do número de lazarentos foi um fenômeno restrito geograficamente, assinalado apenas em algumas regiões européias e que portanto torna-se arriscado generalizá-lo para todo o continente (Sournia, 1986).

De qualquer forma, a partir dos séculos XV e XVI, a tísica começou a ganhar uma dimensão inquietante no cenário europeu, mais pelo número de óbitos que causava periodicamente do que pela constância e generalização das reações sociais de exclusão dos infectados, pois naquela época a doença era de escasso conhecimento popular, sendo que a morte lenta dos pectários dissimulava o império da doença.

Em conseqüência, o período moderno foi pautado pelas tentativas médicas de expandir o conhecimento sobre a patologia pulmonar. Dentre as propostas articuladas naquele momento, destacam-se os posicionamentos do médico e humanista italiano Girolamo Fracastoro que, no ano de 1546, opôs-se ao princípio hipocrático que ensinava que “um tísico nasce de outro tísico”. Na seqüência, deve-se a Fracastoro a menção 
- herdada da medicina árabe - de que a tuberculose era transmitida por "micropartículas" veiculadas pelas correntes aéreas e que se depositavam em roupas e outros objetos (Castiglioni, 1947:548, v.1).

Foi no século XVII e sobretudo na centúria seguinte que anatomistas e fisiologistas conquistaram melhor entendimento sobre a tísica. A aplicação dos princípios cartesianos no campo do saber, que mais tarde seria definido como área de competência da biologia, permitiu que o complexo corpóreo humano fosse concebido como um conjunto articulado de mecanismos. A concepção do homem-máquina, por sua vez, estimulou as aventuras laboratoriais, incentivando o afloramento de perspectivas inovadoras sobre a doença que corroía o peito dos consuntivos.

A importância do cálculo matemático, refletindo os princípios fundamentadores da física clássica, orientou a comunidade médica para a atuação experimental. Entre Descartes e Bayle, os pulmões normais e os afetados foram meticulosamente indagados, medidos, pesados, avaliados pela cor, pelo cheiro e pela consistência. Nesta cirurgia, a história das ciências médicas registra os nomes de uma legião de estudiosos que estabeleceram as bases da fisiologia respiratória e identificaram os tubérculos e as cavernas pulmonares.

Paulatinamente, nos últimos dois séculos da história moderna, o saber clínico sobre a tísica foi sendo reelaborado. Ainda no tempo de Descartes, o francês Franciscus Sylvius descreveu pela primeira vez a existência de pequenas granulações nos pulmões contaminados que, segundo esse médico, quando ganhavam aspecto purulento, faziam surgir cavidades que, pela dimensão e tamanho, anunciavam a gravidade da moléstia. Entretanto, Sylvius manteve-se parcialmente fiel aos ensinamentos hipocráticos, concluindo que os tubérculos nada mais eram que úlceras pulmonares, conseqüentes ao derramamento de substância sangüínea no órgão afetado (Bariéty, 1963).

Poucos anos depois, em 1689, coube ao britânico Robert Morton estender as conclusões de Sylvius, reiterando que a presença dos tubérculos necessariamente precediam a ulceração pulmonar. A nova ordem perceptiva da moléstia exigiu que seus propugnadores rebatizassem a patologia que desde os finais do século XVII passou a ser oficialmente indicada nos alfarrábios médicos por meio da palavra 'consunção', caindo no esquecimento o legado helênico de denominar o definhamento respiratório pela designação de 'fimatose’.

A ampliação do conhecimento sobre a Peste Branca, no entanto, não foi acompanhada pelo estabelecimento de propostas terapêuticas eficientes. A medicina da modernidade clássica dirigiu seus esforços especialmente para a organização de um vasto quadro de signos diagnósticos e prognósticos que, se atestavam a precisão das observações realizadas, também promoviam uma comprometedora confusão entre os sintomas e as causas da doença. O catarro e a hemoptise ainda eram apresentados como as principais causas da moléstia do peito, assim como o 'estado moral' dos pectários era interpretado como motivo concorrente para o enfermamento.

Ao terminar o ‘Século das Luzes’, os médicos ainda faziam largo uso da farmácia da Antigüidade, reproduzindo sistematicamente as estratégias terapêuticas aconselhadas por Hipócrates, Areteus e Galeno, acentuando também a importância do emprego 
do leite humano como elemento fundamental para a cura dos consuntivos. Não eram poucos, pois, os médicos que aconselhavam os tísicos mais abastados a se fazerem acompanhar a todo instante por uma nutriz, para sempre que possível consumir a imprescindível substância humana. As poucas novidades que eram apresentadas como salvadoras dos pectários apareciam recobertas de segredos, sendo exemplar a atuação do médico e revolucionário Jean-Paul Marat que, produzindo e receitando sua 'água antipielmônica', granjeou fortuna e prestígio popular.

A ausência de drogas curativas impôs à medicina daquela época a climatoterapia como o principal recurso de tratamento dos enfermos. Não mais os climas secos eram aconselhados aos pectários, mas sim os ares amenos do campo, onde juntamente com o repouso e alimentação rica em carboidratos, também eram prescritas longas cavalgadas. A chancela clínica ao princípio da equitação como estratégia dinamizadora do aparelho respiratório difundiu-se pela Europa, exigindo que os fimatosos, em qualquer estágio da doença, preenchessem várias horas do dia com exercícios eqüestres e, se impossibilitados para esta tarefa, ficassem confinados em cadeiras de balanço.

Nas últimas décadas do século XVIII, a reorganização médica que se iniciava promoveu a constituição do saber clínico que permitiu a afirmação de um 'olhar' inovador sobre a doença e os doentes, favorecendo com isto o florescimento de novas percepções sobre a tuberculose. O nascente projeto clínico, nas palavras de Michel Foucault (1977), orientou-se pela "espacialização" da enfermidade. A pergunta "o que você sente?” dirigida ao paciente, foi substituída por “onde dói?”, firmando o posicionamento que buscava surpreender a patologia no corpo enfermo e tratá-la segundo um quadro nosológico que se guiava pelas possíveis características da moléstia, prevendo a evolução do caso e instruindo o clínico sobre as opções terapêuticas disponíveis.

A intenção de estabelecer o 'lugar natural' da tuberculose no conjunto das patologias exigiu da comunidade hipocrática um redobrado esforço na tarefa de qualificação dos sinais e dos sintomas mórbidos. As enfermarias hospitalares transformaram-se no espaço onde o olhar médico deveria dominar absoluto, estendendo-se também para a sala de autópsia. A clínica fundamentada na anatomia e na patologia assumiu o papel de promotora da medicina moderna que, mais do que nunca, buscou conhecer os mecanismos específicos do mal do peito.

O hospital despontou no início do século XIX como o local propício para o desvelamento da naturalidade da doença. A sensibilidade clínica, guiada pela lógica iluminista, impunha a regularidade das observações que se definiam como experiência coletiva. Os segredos do corpo enfermo protegido pela opacidade dos órgãos internos ditava a necessidade de uma conduta médica diferenciada.

O código perceptivo da clínica tinha como nova regra o acúmulo e a sobreposição dos olhares. Gaspar Bayle e Théophile Laennec não só observaram minuciosamente milhares de tísicos acamados, mas também fizeram-se acompanhar nas enfermarias por grupos de estudantes, para que cada um deles examinasse os adoentados e, após a discussão do caso clínico, aflorasse do conjunto de anotações, diagnóstico e prognóstico únicos e coerentes ( Laín Entralgo, 1954). 
O abandono do esquema que ensinava que a coincidência dos sintomas definia a identidade da patologia permitiu que Bayle reconhecesse a singularidade biológica da consunção, diferenciando-a de outras entidades mórbidas anunciadas pelo estado febril. Apoiado no método anatomopatológico, coube a este clínico destacar a "natureza essencial” da tuberculose, definindo-a como "toda lesão pulmonar produzida por uma ulceração que, em geral, leva à morte” (Entralgo, 1954:430-431), descrevendo os sintomas clínicos e a aparência pulmonar em cada estágio do alastramento da enfermidade.

Laennec, por sua vez, rejeitou o ensinamento de Bayle sobre a existência de seis espécies de tísica, defendendo a unicidade da doença e esta como resultado de uma inflamação crônica que conduzia à lenta supuração dos tecidos pulmonares.

Tanto Bayle quanto Laennec foram contestados por uma considerável parcela da comunidade médica européia, especialmente por François Broussais e seus discípulos, que julgavam a tísica como conseqüência da irritação dos tecidos, causada por gastroenterite.

Neste mesmo período, Laennec chamava a atenção de seus pares por ter sido o primeiro facultativo a utilizar o estetoscópio no cotidiano da clínica. A ampliação dos sons produzidos pelo trabalho pulmonar permitiu que fosse dado um passo à frente no entendimento do processo tuberculoso. O reconhecimento da 'música do corpo enfermo’ consentiu que novas luzes fossem lançadas sobre a opacidade do órgão comprometido, anunciando com maior antecedência os efeitos da moléstia sobre o aparelho respiratório (Guillaume, 1986).

A indisfarçável contrariedade que despertaram as idéias de Laennec e também o uso do ‘indecoroso brinquedo’ para ouvir o corpo ganhou maior intensidade ainda pelo fato de Laennec ampliar o coro das vozes que afirmavam ser a consunção um 'mal incurável' e portanto destituído de qualquer solução medicamentosa.

O niilismo terapêutico era revelado em um momento no qual a Peste Branca abatia assustadoramente a sociedade européia e quando também se esboçava a organização de uma lucrativa indústria de remédios que tinha na exploração da tuberculose uma formidável fonte de enriquecimento.

Contra Laennec - que se contaminara com o bacilo da tísica possivelmente durante a dissecação de cadáveres infectados - conjugaram-se os aliados de Broussais que denunciaram o aperfeiçoador do estetoscópio como um 'fimatoso mistificador', já que, contrariando suas próprias recomendações clínicas, periodicamente recorria ao tratamento climático nas costas do norte da Inglaterra e, ao morrer, tinha em seu quarto um grande sortimento de plantas marinhas, cujas essências eram consideradas remédio apropriado dos tuberculosos.

A controvérsia instaurada por Laennec e Broussais foi reafirmada pelos seus discípulos, incentivando os debates sobre a tísica, durante toda a primeira metade do século XIX. Afinal, questionava-se, a tuberculose era conseqüência da inflamação ou da irritação dos órgãos? Haveria remédios para o tratamento da doença? A enfermidade era hereditária ou dependia da disposição constitucional do indivíduo? Existiria o contágio tísico? Qual seria o agente infeccioso: os miasmas ou o indivíduo previamente contaminado? 
No período em que se consolidavam as premissas da medicina clínica, os anatomopatologistas buscavam soluções para estes e para muitos outros enigmas centrados na consunção. A recorrência ao microscópio sugeria algumas possíveis respostas. A patologia celular inaugurada por Robert Virchow lançava novos focos de celeuma, sustentando a teoria segundo a qual os tubérculos e a matéria caseosa encontrada nos pulmões afetados correspondiam a distintos elementos, fomentando ainda mais os confrontos acadêmicos.

A grande dúvida que alimentava os temores coletivos do século passado residia no questionamento sobre o eventual caráter contagioso da consunção. Somente no ano de 1865, por meio das experiências realizadas por Jean Antoine Villemin foi possível constatar a condição virulenta e inoculável da moléstia que, como já se tinha noção, não só podia afetar os pulmões, mas outras regiões do corpo humano.

Os experimentos controlados por Villemin consistiram na inoculação em diversas espécies de cobaias sadias de sangue, esputo e matéria caseosa extraídas de infectados, resultando no adoecimento de todos os animais utilizados no laboratório. A conclusão a que chegou Villemin foi que a tuberculose era uma doença contagiosa e dependente de um agente causal específico, uma forma de vida "infinitamente pequena”, como pouco antes havia pontificado o químico Louis Pasteur (Delarue, 1972:12).

Os trabalhos assinados por Villemin e também os de Pasteur foram aceitos reticentemente pela comunidade clínica e pelos higienistas. Afinal, a doutrina miasmática e a concepção sobre a hereditariedade consuntiva contavam com a legalidade da tradição e, até o encerramento do século XIX, a idéia sobre a veiculação microbiana das enfermidades era confirmada por um grupo restrito de médicos. Para a maior parte dos estudiosos, o papel desempenhado pelos micróbios na ocorrência das enfermidades era apenas uma hipótese pouco convincente ou uma condição secundária no desencadeamento das patologias coletivas (Léonard, 1986).

Em 1870, E.J. Woillez, médico especialista em moléstias pulmonares, preferiu anotar em seu Dictionnaire que a explicação básica para a ocorrência da moléstia do peito era a presença de tubérculos acinzentados nos pulmões, acrescentando que Villemin havia realizado pesquisas pouco conclusivas sobre o tema.

Apesar das reações cautelosas, inúmeros pesquisadores - nos quais se incluía o próprio Pasteur - empenharam esforços no reconhecimento do micróbio responsável pela corrupção pulmonar, cabendo ao alemão Robert Koch o pioneirismo na identificação do germe da Peste Branca. Tendo ganho fama desde 1876, quando obteve a cultura pura do bacilo da antraz, Koch recebeu apoio do Estado germânico para desenvolver suas pesquisas, sendo que em março de 1882, o bacteriologista leu perante a Sociedade de Fisiologia de Berlim uma dissertação de sua autoria (1981) em que, obedecendo ao encaminhamento com base na doutrina positivista, comunicava ter descoberto o "agente causal" da tuberculose.

Nesse texto, Koch declarou-se continuador das pesquisas de Villemin, informando que o isolamento do micróbio da consunção consistia numa tarefa urgente e humanitária, já que um sétimo dos óbitos registrados na Europa devia-se à infecção pulmonar, acrescentando ainda que não menos de um terço da comunidade dos traba- 
lhadores adultos apresentava fortes indícios de contaminação pulmonar. Assim, graças a pequenos ajustes nas técnicas laboratoriais vigentes no período, Koch tornou-se o primeiro cientista a visualizar pelo microscópio o germe veiculador da tísica, descrito como um "pequeno bastonete" tingido pelo "belo azul" do corante empregado nos procedimentos da pesquisa.

Identificado o micróbio, Koch procedeu ao exame de tecidos e catarro de indivíduos contaminados e também de algumas variedades animais que apresentavam infecção tuberculosa. A constatação da presença do germe em todos os seres tísicos permitiu ao médico realizar a cultura laboratorial do bacilo e a inoculação do material em centenas de cobaias, onde se incluíam desde hamsters e coelhos, até macacos, cães, gatos e galinhas.

A comprovação experimental do caráter infecto-contagioso do bacilo permitiu ainda que o pesquisador alemão atestasse a unicidade das patologias que até aquele instante a medicina havia teimado em apresentar como moléstias diferenciadas. Oferecendo confirmação científica à hipótese sugerida por Laennec, Robert Koch asseverou que a tísica, a bronquite e a pneumonia caseosas, assim como as tuberculoses intestinal, ganglionar e miliar correspondiam a expressões de uma mesma infecção, alvoroçando ainda mais os centros de debates hipocráticos.

Em coerência com estes princípios, o bacteriologista buscou aproximar a medicina laboratorial das práticas higienistas, sugerindo providências limitadoras da disseminação da doença consuntiva no contexto social.

Segundo Koch, a tuberculose era uma patologia causada exclusivamente pelo bacilo que recebeu o seu nome e que atingia tanto os homens quanto os animais, sendo que o contágio era atestado como resultado da eliminação do micróbio do corpo enfermo, por meio do espirro e do catarro. A permanência da substância em gotículas que flutuam no ar ou o seu depósito em objetos e na poeira consistiam em perigo iminente, pois assim ampliavam-se as oportunidades de infecção dos sadios. Apesar do caráter contagioso da Peste Branca, Koch foi cauteloso em desqualificar a condição hereditária da enfermidade, sugerindo a necessidade de novos estudos sobre o fenômeno.

A definição de um bacilo como agente responsável pela abrangência coletiva da moléstia pulmonar coagiu a Higiene Pública a analisar a consunção como moléstia que poderia ser controlada por intermédio do bloqueio das fontes produtoras do material contaminante. Com isto, desde o final do século XIX, ganharam maior consistência as regras sanitárias que cobravam a desinfecção dos objetos pessoais e do catarro dos enfermos, desdobrando-se na ostensiva vigilância das pessoas e dos animais fimatosos.

A contínua reiteração dos postulados kochianos, entretanto, foi acolhida com incredulidade por uma significativa parcela da corporação dos esculápios, sendo comum as vozes clínicas que, até meados do século XX, negavam a exclusividade da veiculação microbiana da Peste Branca.

Exemplar foi o relativo sucesso das idéias de Auguste Lumière (1931) que, escudado no prestígio angariado por ser irmão do inventor do cinema, elaborou uma longa série de textos onde afirmava que a tuberculose consistia em uma enfermidade fundamentalmente hereditária, sendo o contágio um acidente secundário e desprovido de significado estatístico. 
As pesquisas que se sucederam ampliaram ainda mais o conhecimento fisiopatológico sobre a moléstia que, desde o encerramento da centúria passada, ganhou a denominação oficial de tuberculose, convertendo-se na personagem central de uma área de especialização médica.

O emprego do Raio X pela medicina inaugurou novos recursos para a averiguação clínica do corpo infectado, tornando-se corriqueiro seu uso pelos tisiologistas a partir da segunda década do século XX. A observação detalhada das alterações promovidas pela doença no organismo contaminado permitiu o desdobramento da semiologia da tísica. O interesse pela instrução dos médicos e dos leigos sobre os indícios corporais da presença mórbida possibilitou a organização de um vasto conjunto de sinais e sintomas que, mais do que colaborar na identificação dos infectados, reafirmava a sentença hipocrática sobre o ‘caráter caprichoso’ da tuberculose.

O livro de autoria do professor Félix Coste (1915) constitui-se num exemplo revelador do empenho clínico em detectar a ação destrutiva da enfermidade: ao discorrer sobre mais de uma centena de sintomas patológicos, o médico tomou a precaução de indicar que todos eles poderiam ser relacionados com a infecção consuntiva.

Paralelamente aos aprimoramentos do saber que questionava a Peste Branca, a comunidade especializada desdobrou esforços para a obtenção de uma droga eficiente na cura e na prevenção da tísica. A busca de um tratamento apropriado para a moléstia tornou-se a grande meta da medicina pastoriana. As tentativas medicamentosas resultaram na produção de um surpreendente número de remédios, soros e vacinas que eram anunciados com uma insistência nunca verificada até então, ocupando largos espaços das publicações especializadas e em revistas, almanaques e jornais populares. O próprio Dr. Koch, após ter identificado o agente etiológico do cólera, dedicou-se ao assunto. Em 1890, o cientista alemão noticiou em Berlim, durante uma sessão solene do Congresso Internacional de Tuberculose, o achado de uma droga que curaria todos os fimatosos, evitando, porém, de compartilhar com seus pares a fórmula da substância salvadora.

A esperança da ciência ter decifrado o último grande enigma proposto pela tísica imediatamente ganhou manchetes na imprensa mundial. Repórteres e tuberculosos de todas as partes do mundo dirigiram-se para a capital da Alemanha, desejosos de informações e cura. O primeiro médico britânico a se encontrar com Koch para conhecer detalhes sobre a nova droga - batizada com o nome de tuberculina - foi Arthur Conan Doyle. O clínico e escritor não só buscava esclarecimentos para compor um artigo jornalístico, mas também foi averiguar o possível tratamento de sua esposa consuntiva. Pouco depois, Doyle publicou na londrina Review of Reviews um artigo entusiasmado, exaltando a figura do “domador da Peste Branca” e sua nova descoberta (Dubos, 1952:104).

O fracasso terapêutico da substância produzida por Koch foi retumbante. Apesar do grande número de enfermos que receberam sucessivas aplicações da tuberculina, nenhum dos pacientes conseguiu a melhora desejada. Koch, que havia sido alçado à categoria de herói da modernidade médica e que chegou mesmo a ofuscar a figura de Pasteur, transformou-se em pouco tempo em vilão da história científica, pecha que nem mesmo o prêmio Nobel que lhe foi concedido em 1904 conseguiu minimizar. 
Dos últimos anos do século passado até a descoberta do primeiro quimioterápico específico e eficiente para o tratamento da tuberculose, tornaram-se ainda mais freqüentes as notícias do advento de drogas curativas da tísica. Muitas vezes o próprio meio acadêmico se encarregou de veicular sensacionalistas informações sobre o assunto.

Cita-se como exemplo um livro publicado em 1899, de autoria do professor Albert Landerer, no qual era garantida a cicatrização das cavernas pulmonares mediante aplicações de ácido cinâmico, apresentando-se como prova da eficiência do medicamento uma relação detalhada de centenas de casos clínicos cujo desfecho era a cura total da consunção. Três anos depois, foi a vez do Dr. Friedmann anunciar a existência de uma vacina restauradora da saúde dos infectados, baseada em toxinas atenuadas e extraídas de tartarugas infectadas (Isaacson, 1929).

As promessas de 'curas assombrosas' multiplicavam-se, sendo que, no contexto europeu, os clínicos espanhóis ganharam fama pelo número de vacinas apresentadas como curadoras da enfermidade pulmonar. O microbiologista Jaime Ferrán produziu uma vacina tendo como base um conjunto de germes que ele denominou genericamente bactérias alfa e com isto atraiu uma legião de enfermos para o seu sanatório, em Santander.

Em continuidade, o Instituto Ravetllat-Pla, sediado na cidade de Barcelona, talvez tenha sido a organização que mais insistentemente propagandeou o valor curativo de suas drogas. Este Instituto fazia publicar anualmente extensos volumes compostos de depoimentos de tisiologistas e de antigos pectários que prometiam a 'cura radical' da doença do peito, mediante o emprego de "hemo-antitoxinas e soros RavetllatPla” (Cendrero, 1942). Por fim, as promessas se somavam, revelando-se como meras ilusões que motivavam os condenados à morte lenta a nutrir esperanças e consumir tudo o que lhes era oferecido a preço de ouro.

Afastando-se da regra, algumas outras associações buscavam fugir das promessas fáceis e sedutoras. Nos últimos anos do século XIX, a unidade parisiense do Instituto Pasteur estabeleceu uma linha de pesquisas vocacionada à obtenção de uma droga para combater a tísica, sob a responsabilidade de Ilya Metchnikoff, um cientista russo que havia ganho fama na área da imunologia.

O Dr. Metchnikoff orientou suas pesquisas à busca de uma 'brecha' na formidável resistência do bacilo de Koch que, pelo revestimento ceroso, mostrava-se imune a qualquer substância que não ameaçasse igualmente a vida do hospedeiro. Os esforços do Instituto Pasteur, entretanto, pouco surtiram efeito, sendo as pesquisas interrompidas em 1916, ano em que ocorreu a morte do médico russo (Sokoloff, 1946).

A tentativa que maior êxito obteve no combate à consunção resultou na criação da vacina BCG, obtida experimentalmente em 1906 e inoculada em crianças e adolescentes a partir da década de 20. Entretanto, a droga - cuja denominação é composta pelas iniciais que designam o bacilo biliado preparado pelos franceses Calmette e Guérin sofreu forte resistência pública.

Primeiramente, a imprensa encarregou-se de distorcer as propriedades da vacina, anunciando-a como curativa da fimatose e não como simples solução preventiva, composta de bacilos atenuados de tuberculose bovina. Em seguida, a aplicação do preparado em cerca de 272 crianças da cidade de Lübeck provocou um terrível acidente 
que comprometeu os esforços de combate à tuberculose. Isto porque as culturas microbianas não tinham sido convenientemente atenuadas, resultando na infecção ou morte de pelo menos metade das crianças pretensamente imunizadas. Em conseqüência, uma campanha mundial foi ativada contra a BCG, fato que adiou por alguns anos o emprego disseminado da substância protetora (Calmette, 1927; Bernard, 1939).

A impotência medicamentosa no tratamento dos consuntivos impôs como solução paliativa o dimensionamento clínico do regime dietético, do descanso e da climatoterapia. Fórmulas antigas, registradas desde a aurora das civilizações ganharam redobrado foro de socorro ideal aos enfraquecidos do peito.

Se no início do século XIX ainda prevalecia a orientação segundo a qual os ambientes praiano e campestre ou mesmo a reclusão em quartos fechados constituíamse nos espaços apropriados para o tratamento dos tributários da Peste Branca, a partir de meados daquela centúria, a medicina germânica tornou-se propulsora do movimento que atestava ser as regiões montanhosas e de clima frio o contexto ideal para o tratamento dos infectados e dos fracos do peito, inaugurando a era sanatorial de isolamento dos pectários.

Na abertura do século XX, a medicina alicerçada no método experimental de Claude Bernard e na teoria microbiana de Louis Pasteur havia construído novas explicações sobre a tuberculose e seus mecanismos de infecção. No mesmo período, as propostas curativas da moléstia pulmonar multiplicavam-se em número, sem contudo chegar a uma fórmula eficiente, capaz de limitar o território da tuberculose.

O defasamento entre o acúmulo de conhecimentos fisiopatológicos 'modernos' e a fragilidade das respostas terapêuticas motivadas pela tísica impuseram uma dinâmica própria às ações sanitárias e aos comportamentos sociais, colocando em destaque não só a doença como objeto de indagações científicas, mas também a imagem historicamente construída dos tributários da Peste Branca. 


\section{2}

\section{A Trajetória das Imagens}

As definições decorrentes da anatomopatologia e da bacteriologia permitiram a elaboração de um modelo ontológico explicador da tuberculose como fenômeno biológico. A identificação do germe disseminador da tísica encontrou continuidade lógica no reconhecimento das fontes de contágio e dos processos destrutivos que atingiam os tecidos e os órgãos. Em decorrência, o acúmulo de noções acerca da Peste Branca atuou como recurso orientador não só das práticas médicas, mas também dos limites da convivência entre os sadios e os contaminados, especialmente nos terrenos marcados pela concentração populacional.

As avaliações dos comportamentos públicos e privados daqueles que transpuseram as fronteiras da saúde alimentaram infinitos debates, favorecendo as discussões promovidas pela medicina, pela literatura e por variadas instituições sociais. Nesse processo, os doentes foram analisados genericamente por Comte e por seus discípulos como indivíduos que haviam enfermado porque de algum modo colocaram-se contra as regras garantidoras do bom funcionamento social. A partir disso, coube ao positivismo conferir validade científica ao milenar pressuposto segundo o qual as moléstias se abatiam sobre aqueles que reagiam negativamente ao ordenamento imposto, aproximando as doenças físicas e psíquicas do conjunto de ‘patologias sociais' que colocavam em risco a sociedade urbano-industrial.

A busca do entendimento da Peste Branca e dos fimatosos, neste enquadramento, suscitou a cristalização de uma multiplicidade de representações sobre o doente do peito. Em continuidade, a 'moléstia misteriosa' e os tísicos tornaram-se objeto de uma série de tratamentos metafóricos que resultaram na percepção da vida infectada como sinistro espelho dos desregramentos e perversões promovidas pela existência grupal, especialmente após as Revoluções Burguesas.

\section{As Raízes das Imagens}

O século XIX foi o momento privilegiado na articulação e divulgação das mensagens que buscavam retratar, em minúcias, o comportamento atribuído aos consuntivos. No entanto, torna-se necessário recordar que, desde a Antigüidade, os fimatosos eram 
alvos de explicações que apontavam para o caráter distintivo da doença do peito. Entre os hebreus, a presença da tuberculose foi anotada como punição divina aos infratores dos mandamentos religiosos. A advertência de que a enfermidade se constituía em castigo sagrado imposto aos pecadores encontra-se registrada no Velho Testamento, nos Livros do Deuteronômio e no do Levítico. Os infiéis foram ameaçados com a 'tísica e a febre', sendo que Moisés advertiu que todos aqueles que rejeitassem os estatutos de Israel seriam assolados pelos males que "consumam os olhos e atormentam a alma" (Bíblia Sagrada, 1974:134).

Mesmo buscando estabelecer explicações naturais para a ocorrência e o desenvolvimento do ciclo patológico, os gregos também não fugiram da dimensão enigmática emprestada aos indivíduos com os pulmões comprometidos. A composição hipocrática da spes phthisica associou averiguações do quadro clínico da moléstia com notas sobre a pretensa conduta peculiar dos fimatosos que, diferenciados das vítimas das demais enfermidades, foram caracterizados como exageradamente egoístas, excessivamente crédulos na rápida recuperação da saúde e laboriosos em um grau incompatível com o estado doentio (Dubos, 1952).

O ambiente medieval, dado o caráter espiritual em voga, contextualizou as concepções bíblicas referentes à tuberculose. A consunção foi apresentada não só como punição aos ímpios, mas também como moléstia que se abatia sobre os puros de alma, para anunciar a fragilidade da carne e a necessidade de contínuo aperfeiçoamento da existência espiritual.

Na etapa da modernidade clássica, as primeiras hipóteses sobre a possibilidade contagiosa da doença contou com aceitação limitada, circunscrita a apenas algumas áreas do sul da Europa. Enquanto a maior parte do continente acomodava-se na idéia segundo a qual a tísica era uma patologia hereditária ou decorrente da inflamação dos tecidos pulmonares, algumas cidades italianas foram em sentido contrário, gerando regimentos que adotavam o princípio infectante da tuberculose.

Desde o ano de 1699, a República de Luca passou a cobrar notificação oficial de todos os fimatosos em tratamento médico, exigindo também que os prédios onde ocorressem óbitos pela enfermidade pulmonar fossem prontamente purificados por meio da caiação das paredes e da queima de enxofre e de ervas odoríficas. Meio século depois, o Grão-Ducado da Toscana determinou novas exigências, publicando um edito que proibia a venda ou doação dos pertences dos infectados, sem que antes os bens passassem por diversas fervuras despoluidoras, medida que nos anos seguintes foi imitada pelos Estados ibéricos.

Em conseqüência destas disposições, os consuntivos receberam na Itália um tratamento diferenciador, sendo que, no ano de 1782, o reino de Nápoles patrocinou a instalação do primeiro hospital destinado exclusivamente aos doentes pulmonares, localizado na região praiana. A existência do nosocômio especializado permitiu que novas leis fossem estabelecidas, inclusive uma que punia com multa e expulsão do reino todos os enfermos que não aceitassem o isolamento hospitalar. 


\section{A Modernização das Representações}

A partir dos últimos anos do século XVIII, os escritores românticos adotaram a consunção e seus tributários como tema recorrente, sendo raras as novelas, as poesias e as pinturas que deixaram de incorporar os fracos do peito em suas descrições, mesmo que incidentalmente. Os discípulos de Goethe, Chateaubriand e Byron convergiram para a imitação de seus 'mestres', fazendo proliferar uma multidão de personagens aflitos e doentios, todos eles guardando semelhança próxima com o vulto depauperado e sombrio da espanhola Dona Tadea Arias de Enriquez, modelo inspiradora de uma pintura assinada por Francisco Goya, nos primeiros anos do século XIX.

O predomínio da motivação literária e artística centrada na tísica não pode ser explicado apenas pela alta taxa de disseminação da enfermidade nos terrenos urbanos e de industrialização incipiente, representados no início da centúria passada pelas principais cidades da Inglaterra e da França. É necessário levar em consideração que a Graveyard School - designação que busca aglutinar os autores e artistas românticos apropriou-se da moléstia para melancolicamente anunciar a angústia existencial que se abatia sobre uma classe de privilegiados que fora ferida de morte no momento que sucedeu à Revolução Francesa.

Com isto, os escritores românticos encontraram na tuberculose um recurso conveniente para negar o mundo concreto e confessar o desencanto da vida social. A ansiedade da busca de um 'segundo eu’ rimava com a desilusão produzida por uma sociedade envolvida pelos ideais de igualdade dos direitos dos cidadãos, favorecendo as cirurgias introspectivas e de auto-observação. Com isso, o comportamento mórbido e ensimesmado passou a ser concebido como sinônimo de requinte e delicadeza por um grupo infelicitado pela ameaça de decadência na hierarquia social.

Mais ainda, os românticos se deixaram enveredar pela tuberculose porque esta enfermidade se apresentava historicamente marcada por uma aura que passou a ser concebida como enobrecedora. Definida como ‘febre das almas sensíveis', a consunção foi abraçada pelos textos literários como argumento exaltador dos dotes de uma larga parcela da elite intelectual. O mal dos pulmões foi assumido como cabal comprovação da sensibilidade e da genialidade que dirigia a existência individual e permitia a composição dos escritos românticos. A febre dos corpos confundia-se com o fogo das paixões e a exacerbação dos desejos, sendo que o próprio Laennec incriminou as aventuras amorosas intensas ao mesmo tempo como produto e conseqüência do processo tísico (Hillemand \& Gilbrain 1980).

A literatura da primeira metade do século XIX, por isso, afastou-se silenciosamente do padecimento que se abatia sobre os fimatosos pobres que se aglomeravam nos cortiços e nas fábricas e que encontravam a morte nos becos das grandes cidades ou nas enfermarias coletivas. Ausentes dos cenários da miséria, os poetas e escritores românticos conferiram à tuberculose o mágico poder de redefinição positiva da vida. Com isso, a moléstia foi confinada a uma dimensão mítica da trajetória individual, cobrando lágrimas compadecidas e solidárias de uma sociedade que, de regra, não acreditava no fatídico contágio. 
Neste encaminhamento, a literatura romântica diferenciou-se dos textos que a precederam. Isto ocorreu porque, nos momentos anteriores, as moléstias eram geralmente registradas literariamente apenas por meio de personagens senis, excetuandose os escritos tematizados pelas quadras pestíferas. A consunção permitiu que a febre, a fraqueza, a hemoptise, o delírio e a morte fossem materializados em existências jovens, bastando uma contrariedade qualquer para condenar os corpos juvenis à extinção. Refletindo este posicionamento, em 1826, Shelley explicou a doença e a morte de seu amigo e também poeta John Keats como resultado das duras críticas que este recebeu pela publicação de um novo livro de versos. Imediatamente, o escritor ofendido foi vitimado por sucessivas crises de hemoptise que em poucos dias o levaram à morte (Dubos, 1952).

A família Brontë constituiu-se no modelo ideal de padecimento físico e sentimental que alimentava o paradigma romântico. A persistência avassaladora da tuberculose no clã foi não só entendida como a confirmação da hereditariedade da doença, mas também como elemento explicativo da genialidade que orientava as composições de Emily e Charlotte (1939). Nas páginas de Wuthering Heights, a patologia desponta como marca consagradora da pureza dos espíritos que aceitaram o fim doloroso com um orgulho que surpreende, pois a 'bela morte' produzida pela tísica conferia o poder libertador das angústias terrenas.

As observações registradas sobre os personagens que tinham os pulmões arruinados se avolumavam, compondo perfis mórbidos sensíveis aos olhos românticos. A genialidade e o afã por realizações eram explicadas como resultados do avanço da tuberculose, cuja febre se expandia e impregnava a vida adoentada, produzindo agilidade das idéias e bons frutos no trabalho intelectual exagerado.

Na verdade, o que garantia o caráter excessivo nas ações cotidianas pode ser equacionado não só como fruto da percepção da brevidade da existência ameaçada pela peste, mas sobretudo como resultado do uso desmedido de opiáceos, base de muitos remédios indicados pela medicina do século passado. O láudano era aconselhado como medicamento adequado para o combate à tosse, ao cansaço, à dor e à diarréia que atormentavam os pectários. Por isso, muitos enfermos tornaram-se dependentes da droga que, além de agir como excitante, conduz à efervescência mental e à liberação do inconsciente, fenômenos que eram atribuídos unicamente ao processo patológico.

A beleza e a sensualidade feminina também eram articuladas ao estado consuntivo. A tez pálida, os olhos lacrimejantes, as faces rosadas e a rouquidão da voz davam destaque aos corpos lânguidos, à alvura dos dentes e à tonalidade dos cabelos, tornando os 'anjos tísicos' modelos da estética feminina cultuada pelos românticos, sendo que as mulheres que correspondessem a este perfil eram situadas como objetos máximos dos desejos masculinos. A 'desmaterialização corporal' reconhecida nas fimatosas ensejou a elaboração de uma anatomia erótica que analisava meticulosamente o corpo feminino: cabelos, busto, mãos, pés, unhas, tudo enfim era avaliado em minúcias e registrado como sedutoramente belo e cobiçado.

A moda da vestimenta contribuía ainda mais para exponenciar o etéreo e o sensual, ganhando aceitação os tecidos leves, transparentes e esvoaçantes. No ano de 1832, Barbey D’Aurevilly sintetizou exemplarmente algumas destas percepções ao re- 
tratar os encantos da tuberculosa Léa que, segundo os olhos de seu enamorado, era "a mais bela das criaturas” (D’Aurevilly, 1832: 49) porque apresentava olheiras profundas, rosto pálido e um corpo abatido que agitava-se sensual e freneticamente.

Nem mesmo as crianças tuberculosas deixaram de receber um tratamento sensualizado pela pena romântica. No livro A Cabana do Pai Tomás, a pequena Evangelina foi retratada como "a mais bela de todas as crianças" (Stowe, 1962: 52), sendo que durante o desenrolar da trama são freqüentes as observações que avaliam positivamente todo o corpo infantil.

Filha de pai pectário e de mãe afetada no comportamento mental, Evangelina nutria um indescritível horror pelo sistema escravista, sentimento que se ampliou com a evolução da doença que a consumia. Morta, as considerações tecidas sobre a pequena tuberculosa não deixaram de exaltar a profunda sensibilidade da falecida, acrescentando-se uma frase que sintetiza eficazmente a percepção ultra-romântica sobre os fracos do peito: "não nasceu para viver aqui, na terra" (Stowe, 1962:52).

$\mathrm{O}$ padrão físico e a sensibilidade apurada que foram imputados às mulheres pectárias também ganharam sentido no semblante masculino. Fréderic Chopin talvez tenha sido o tuberculoso cuja imagem doentia foi a mais invocada pelos românticos. Seu amigo e rival Franz Liszt descreveu-o segundo o modelo de beleza do tempo, anotando a transparência de sua cútis, o encanto do seu cabelo e a distinção de seu porte frágil de consuntivo.

Tudo isto excitava a cobiça feminina: George Sand (1947) confidenciou que Chopin era um "homem irresistível” e "divinamente delicado", enquanto um amigo do compositor dizia que "ele vira a cabeça de todas as mulheres e provoca ciúmes em todos os maridos". O encanto do fimatoso polonês ganhou maior sentido ainda pela inconstância de seu temperamento. "Não há nada de permanente nele a não ser sua tosse”, pontificava George Sand que, apaixonada, entendia que a moléstia ampliava a genialidade do companheiro. Isto porque a escritora associava a tísica às súbitas transformações do "estado de alma” do músico, ocasiões que, segundo ela, Chopin compunha partituras de incomparável qualidade artística.

A aparência e o comportamento considerados próprios dos tuberculosos transformaram-se em regra existencial que vigeu durante o período mediado pela Revolução Francesa e pelo Segundo Império. Assumida como código de vida, a atitude atribuída aos fimatosos exigia que todos se alimentassem parcamente e se vestissem com trajes que sugeriam o estado mórbido do corpo e o padecimento do espírito.

Os esforços para ganhar a aparência consuntiva eram intensos, pois o semblante doentio atraía atenções e despertava fantasias, abrindo chances para o sucesso artístico. Nas Scènes de la Vie de Bohème, Henry Murger (1936) colocou na boca de um pianista que atuava em bares suspeitos palavras de glorificação à condição tuberculosa, anunciando a infecção como produtora de uma sensibilidade exaltada cujo fim último era o sucesso artístico e intelectual do tísico.

Esta obra murgeriana, datada de 1851, define a consunção como resultado da vida desregrada da boêmia, localizando a moléstia e suas vítimas em um grupo de indivíduos que desfrutava de um padrão econômico e social que em nada se assemelha- 
va com o da elite tuberculosa retratada pela literatura das décadas anteriores. Com isso, desde o 'ciclo revolucionário de 1848', deu-se início à revisão da imagem imputada aos tísicos que, mantendo-se fiel aos clichês explorados pelo romantismo, passou a exibir esquemas condenadores da trajetória de vida e dos comportamentos atribuídos aos afetados do peito.

Os novos posicionamentos sociais e sanitários que foram esboçados naquele momento cumpriam o papel negador da boêmia e da tuberculose como marcas da camada culta e elegante, reconhecendo a consunção como enfermidade própria da população pobre e marginalizada. A partir de então, a tuberculose foi associada à miséria que dizimava o lumpemproletariado e os trabalhadores industriais, enfim, toda uma legião de injustiçados que Friedrich Engels analisou segundo a perspectiva sociológica em $A$ Situação da Classe Trabalhadora na Inglaterra e que Victor Hugo dramatizou por meio da criação literária em Os Miseráveis.

Os motivos que permitiram a alteração dos posicionamentos coletivos sobre os pectários são pouco claros, mas pode-se pensar que neste período os casos de tísica tornaram-se bem menos freqüentes nos círculos burgueses da Europa. As taxas de mortalidade pela moléstia apontam uma significativa queda, pois, se no ano de 1838 a tuberculose cobrou 4 vidas em cada mil britânicos, tal índice caiu para 2,7 em 1860 e para 1,3 na virada de século.

A pouca eficiência dos recursos médico-terapêuticos disponíveis há 150 anos faz com que algumas explicações sejam tentadas para justificar o decréscimo relativo de óbitos e possivelmente da mortalidade produzida pela tísica: o afastamento dos infectados dos núcleos urbanos maiores, a eventual mutação da estrutura bioquímica do agente causal e a redução do número médio de componentes da família inglesa são elementos analisados pelos estudiosos, mas que pouco têm contribuído para o entendimento do fenômeno.

A hipótese que atualmente se aventa com maior intensidade - apesar de também não ser conclusiva - aponta para o aumento da resistência orgânica individual como evento limitador da legião de infectados. Isto porque houve seguidas melhorias nas condições materiais de vida dos agrupamentos proletários da Inglaterra, principalmente após a organização de uma vasta rede distribuidora de gêneros alimentícios, fato que implicou o rebaixamento dos preços e, por óbvio, no maior consumo de alimentos pelas camadas de trabalhadores urbanos (McKeown, 1977 e 1990).

Sob nova circunstância, elaboravam-se padrões inéditos para o século XIX: a saúde e a abundância de gorduras transformaram-se em moda e culto. O casal coroado britânico tornou-se o novo paradigma de corpo e de moralidade que foi reproduzido nos lares burgueses da Europa da segunda parte da centúria. A rainha Vitória e seu consorte Alberto eram corpulentos, e nos momentos de apresentação pública, mostravam-se alegres, ágeis, enérgicos e moralmente equilibrados.

À saúde do corpo e do espírito somava-se o gosto pela fartura de alimentação pesada, não faltando na mesa real uma grande variedade de peixes, guisados e assados, além de inúmeras sobremesas e vinhos. Refletindo a nova proposta, Jean Renoir e Édouard Manet, dentre outros, serviram-se de modelos robustos, até mesmo beirando a obesidade, para retratar as novas concepções estéticas e clínicas preconizadas naquele período. 
Em continuidade, a medicina pública buscou enquadrar a tísica no conjunto de 'moléstias sociais', definindo-a como Peste Branca e com isto fazendo lembrar as taxas alarmantes de morbidade e de mortalidade produzidas pela doença no contexto das camadas mais pobres da população.

Complementando a proposta clínica, os higienistas compuseram novas estratégias de intervenção no cotidiano coletivo, sem no entanto abandonar os pressupostos fantasiosos que pairavam sobre o comportamento infectado. Neste contexto, definiuse o julgamento moral dos fimatosos, tornando a vida privada dos enfermos um espetáculo que atraía o interesse coletivo. A literatura, associada à medicina, continuou a ocupar páginas e mais páginas para revelar a intimidade dos pectários que, segundo a tessitura murgeriana, caracterizavam-se psicologicamente pelo amálgama de "sentimentos maldosos e instintos ferozes” (Murger, 1936:170-171).

Ainda no momento inaugural desta nova etapa de verificação da vida consuntiva, outro enredo de tendência ficcional que ganhou ampla aceitação foi A Dama das Camélias, de Dumas Filho (1977). Isto se deveu ao fato da obra ter reunido todos os estereótipos organizados em torno do personagem tuberculoso, especulando sobre a trajetória existencial de uma conhecida cortesã francesa, opções que garantiram o sucesso editorial do texto, publicado no ano de 1852.

O impulso inicial para a composição deste romance deveu-se ao encontro do escritor com a cortesã Marie Dupleiss, cujo nome de batismo era Alphonsine Plessis. Alphonsine era uma camponesa da Normandia que, em conseqüência da miséria que assolava a região, assumiu a prostituição como estratégia de sobrevivência. Nessa condição, conheceu e contraiu matrimônio com um inglês de posses, porém, enviuvou em pouco tempo. Endinheirada, Marie Dupleiss rumou para a capital dos franceses, onde passou a levar uma vida faustosa, ganhando destaque no ambiente metropolitano e tornando-se presença obrigatória nas reuniões sociais que agitavam o cenário parisiense.

Já diagnosticada como consuntiva, Mme. Dupleiss conheceu Dumas Filho, mantendo um consórcio amoroso que se estendeu por alguns meses. Rompido o relacionamento, o escritor retirou-se para a Espanha, enquanto a amante permaneceu na 'cidade-mãe do escândalo', onde faleceu em 1847, aos 23 anos de idade. O velório, assim como o leilão dos bens deixados pela morta, constituíram-se em acontecimentos sociais concorridíssimos, impressionando o viajante Charles Dickens que registrou a emoção despertada pelos eventos, os quais o fizeram concluir que a Dama das Camélias era uma espécie de heroína nacional, comparável a Joana D’Arc.

De regresso a Paris, Dumas Filho soube do óbito de sua ex-companheira, escrevendo o livro que anunciava tratar de uma 'história verdadeira', testemunho de uma geração na qual a 'ciência do bem e do mal' estava definitivamente consolidada. Para alcançar estes objetivos, o autor tingiu a figura da pectária Marguerite Gauthier com as cores de uma mulher bela, sedutora e voluptuosa que, pela vida de orgias, tornou-se escrava da doença do peito.

Apaixonada pelo ingênuo Armand, nem mesmo as tentativas de recuperação física e moral patrocinadas pelo amante surtiram os efeitos desejados. A reclusão no território campestre e o descanso prolongado foram inúteis, pois a enfermidade progre- 
dia e a 'febre de desejos’ conduziu a pectária novamente a Paris. Ali, Mme. Gauthier foi rejeitada pelos seus antigos companheiros de 'devassidão', pois os novos comportamentos instruíam que 'no seu mundo não há amigos se não houver saúde’.

No território da literatura, pela primeira vez aflorava o repúdio declarado ao tuberculoso, o que fazia deste um ser desprezado e que por isso deveria empenhar-se na recuperação da saúde, como em certo momento confidenciou a Dama das Camélias:

Voltei para casa às quatro horas, jantei com bastante apetite. Essa saída fez-me bem. E se eu me curasse? Como o aspecto da vida e da felicidade dos outros faz desejar viver aqueles que, na véspera, na solidão de sua alma e na sombra de seu quarto de doentes, desejavam morrer depressa. (Dumas Filho, 1977:201)

A esperança de restabelecimento da saúde foi apenas um sonho para a cortesã arrependida. A corrupção do corpo seria o castigo para a vida dissipada. A morte da enferma foi despojada de qualquer aura redentora, para ser revelada como algo sombrio, aterrorizador, até mesmo repugnante: "Os olhos eram apenas dois buracos, os lábios tinham desaparecido e os dentes brancos cerravam-se uns contra os outros. Os longos cabelos negros e secos estavam colados às temporas e velavam em parte as cavidades verdes das faces” (1977:42).

Os medos despertados pela enfermidade e a adequação da tísica como doença dos miseráveis faziam com que a elite negasse a presença da moléstia em seu meio social. Quando a mortal enfermidade invadia os lares burgueses, o fato era protegido pelo absoluto sigilo familiar, sendo raros os infectados que viam alguma positividade na experiência de vida com a tuberculose.

Em 1882, enquanto Robert Koch exigia segredo absoluto sobre a sua condição pectária, a jovem pintora Marie Bashkirtseff (1943:326) desviava-se da regra, confidenciando em seu Diário: "esta posição de condenada, ou cousa que o valha, diverte-me (...) há nisto um certo encanto. É antes de tudo, uma novidade”.

A partir da segunda metade do século XIX, as celebrações byronianas perderam força, permitindo que a doença dos pulmões fosse assumida como experiência com sentido único: a degradação do enfermo.

Para clarear este novo posicionamento, os irmãos Edmond e Jules Goncourt (1982) fizeram-se alunos da faculdade de medicina de Paris para ganhar conhecimentos que resultaram no romance Madame Gervaisais, lançado a público em 1869.

Empenhados na composição de uma 'sociologia dos tísicos', os escritores abraçaram as teorias clínicas vigentes, conferindo-lhes lastro por meio da observação demorada de uma série de fimatosos isolados tanto nas enfermarias hospitalares quanto no recinto doméstico. Como resultado, surgiu uma obra que beira o registro biográfico, pois declaradamente inspirada no curso da vida da infectada Nephtalie de Courmont, tia dos irmãos Goncourt.

A descrição dos efeitos nefastos da tuberculose sobre o corpo e a personalidade de Mme. Gervaisais é intensa e assustadora, ocupando quase que o total das páginas do texto goncourtiano. Transferindo-se de Paris para Roma, a consuntiva foi pouco a pouco sendo despojada da beleza corporal, tornando-se uma mulher abatida e feia. 
Os 'efeitos morais’ da moléstia que a consumia eram múltiplos: anti-clerical, assumiu a vida mística e dependente de uma relação sado-masoquista com diversos pregadores jesuítas; pudorosa, revelou-se facilmente excitável no sexo, até mesmo com o nu das estátuas expostas nos museus e, mãe sempre devotada, abandonou o próprio filho, entregando-se a um egoísmo desmesurado, renunciando às relações sociais e à riqueza herdada do esposo.

O definhamento físico e a ruína moral da pectária foram explicadas pelos Goncourt como resultado da ação destrutiva promovida pela consunção. As dificuldades respiratórias, segundo os escritores, causavam uma semi-asfixia que intoxicava os pulmões e afetava o funcionamento do cérebro que, impedido de funcionar plenamente, gerava excitação sexual e 'loucura religiosa'. Em continuidade, os estragos cerebrais condenaram a consuntiva, que contava com 40 anos de idade, a voltar a um estado mental infantil, fazendo-a comportar-se como uma criança de 12 anos.

As teses animadoras da trama assinada pelos Goncourt revelam a transposição para a literatura do ideário que a comunidade médica européia vinha articulando sobre o comportamento fimatoso, conferindo a Madame Gervaisais a dupla função de instrumento justificador e ao mesmo tempo popularizador dos enunciados clínicos. Nesta circunstância, a medicina ensinava que o tuberculoso era um tipo limite de vida, defendendo a condição pervertida dos doentes do peito.

A transparência da pele, a ausência de pilosidade, o surgimento de mamilos pronunciados nos homens e a inversão sexual feminina foram alguns outros elementos registrados nas conclusões das pesquisas especializadas, remetendo os contaminados para o território das ambigüidades onde o masculino e o feminino, o adulto e 0 infantil, o ingênuo e o perverso, enfim, onde todos os opostos se combinavam diabolicamente, resultando na nova e assustadora imagem ajustada aos personagens consuntivos (Grellet, 1983).

O caráter enigmático emprestado aos tuberculosos orientava os ensinamentos médicos e os devaneios ficcionais. Tanto uns quanto outros deixaram-se fascinar pelas pretensas aberrações perpetradas pelos tísicos, exigindo que facultativos e escritores se lançassem vorazmente na exploração das perversidades dos contaminados, dando especial ênfase ao comportamento sexual dos enfraquecidos do peito.

Perseguindo este intento, o Dr. Fonssagrives (1880) reuniu a autoridade docente da escola médica de Montpellier com o prestígio de autor de inúmeras obras fundamentadoras da medicina pulmonar para estender-se na observação das atitudes sexuais dos fimatosos. Ao prescrever a necessidade de rígida "higiene moral" dos adoentados, o clínico acrescentou que os tísicos, por se sentirem próximos da morte, apresentam um exagerado “apetite genésico”, cabendo aos clínicos inibir tal tendência por meio de medicamentos e dietas especiais.

A alegada anormalidade venérea dos tísicos assegurou a existência de toda uma vertente literária que garantia o sucesso de venda de livros na exploração dos comportamentos sexuais condenados pela moral vitoriana. A escritora que se ocultava sob o pseudônimo de Jane de la Vaudère (s.d.) foi uma das autoras que assumiu o tema, produzindo ‘composições eróticas' povoadas de personagens tuberculosos homosse- 
xuais e sodomitas. Em um de seus livros, a trama se encerra com uma libertina infectada esvaindo-se em hemoptise, mas mesmo assim reservando seus últimos instantes de vida para presenciar e bendizer o coito anal de um casal que adotou como discípulos e que, pela licenciosidade do ato praticado, foi presenteado com todos os bens acumulados pela valetudinária.

A consunção e seus tributários transformaram-se na grande metáfora de tudo o que era considerado ameaçador, horripilante, nojento. Exemplo disto é uma série de livros publicada em Portugal no início do século passado e que tinha como título geral Tuberculose Social, onde, no décimo volume da coleção, o autor combateu a obrigatoriedade do celibato sacerdotal. Neste ensaio declaradamente anarquista e portanto anti-clerical, os estigmas sobre os pectários não foram colocados de lado, sendo que o enredo da obra constitui-se na história de um padre infectado que se deixou dominar pelos seus impulsos exageradamente eróticos, pervertendo e contaminando várias de suas inocentes fiéis (Gallis, 1903).

\section{Tempo das Viagens}

Rejeitados pelo mundo dos sadios e atormentados pela doença que corrói, muitos tuberculosos acomodaram-se às prescrições médicas, rumando para longas e sucessivas viagens que prometiam a recuperação da saúde. Desde os fins do século XVIII, os clínicos passaram a reiterar com insistência a necessidade dos pectários mudarem de ares, indicando os climas quentes da Europa meridional como propícios para o tratamento dos pulmões, acompanhando de perto as instruções preconizadas pela medicina greco-romana.

No lado ocidental do continente, regiões que há muito vinham sendo visitadas pelos fimatosos consistiam no extremo sul da Península Ibérica, nas ilhas Baleares e nas praias banhadas pelo mar Tirreno. A constância das peregrinações de consuntivos para estas áreas fomentou o repúdio aos doentes com os pulmões corroídos, tornando os locais de cura pioneiros na elaboração de códigos sanitários que limitavam a liberdade dos contaminados.

Quando Chopin teve a sua saúde pulmonar comprometida, os médicos lhe recomendaram o afastamento do inverno rigoroso, prescrevendo uma temporada na ilha de Majorca, convenientemente situada a pouca distância do continente europeu e protegida pelo clima mediterrânico. Por isto, em 1839, George Sand conduziu o compositor para a 'ilha encantada', apostando na melhora da saúde do seu companheiro.

Entretanto, a estada em Valdemosa revelou-se constrangedora, fazendo com que tudo se tornasse difícil, desde a compra de leite de cabra até a locação de um imóvel minimamente confortável, pois os majorquinos nutriam verdadeiro horror aos visitantes infectados. Como Chopin piorasse da saúde, o regresso à França tornouse medida urgente, situação que uma vez mais denunciou a intensidade da aceitação da teoria contagionista pelos ibéricos. O transporte do enfermo até a cidade de Barcelona foi oneroso, inclusive porque George Sand foi obrigada a cobrir os custos da 
cama ocupada pelo músico, pois logo depois de usado, o leito foi lançado à fogueira, como medida preventiva (Sand, 1984).

O fato dos ilhéus acreditarem no perigo contagioso foi julgado pela escritora como fruto da superstição típica de um 'povo bárbaro'. Entretanto, o repúdio aos doentes pulmonares foi observado inclusive em Nápoles, quando o compositor tísico Nicolò Paganini foi severamente perseguido pelas autoridades, ao tentar estabelecer residência naquela cidade . Em Roma, René de Chateaubriand também registrou a mesma situação, pois ao se encarregar da venda dos móveis utilizados por uma amiga tuberculosa, não encontrou comprador, sendo obrigado a queimar a maior parte das peças, por ordem da milícia local (Grellet, 1983).

O temor inspirado pela moléstia ganhou novos espaços, limitando a 'febre do judeu errante' que animava a constante troca de moradia pelos personagens fimatosos. Mesmo assim, nos Estados Unidos, muitos dos pioneiros que no decorrer do século XIX desempenharam a tarefa de expansão das fronteiras americanas, eram tísicos que procuravam territórios apropriados para o tratamento da saúde. As regiões do Colorado, Utah, Texas, Novo México, Arizona, Kansas, Nevada, Oklahoma e Califórnia foram áreas de concentração de infectados, sendo que a cidade de Los Angeles foi designada como a 'capital nacional dos consuntivos', por volta de 1880.

Espelhando as mudanças das atitudes coletivas em relação aos tuberculosos, no término do século XIX tomou corpo um movimento que visava à aprovação de uma lei que exigiria que todos os cidadãos norte-americanos contaminados pela doença utilizassem um sino pendurado no pescoço, para assim alertar os sadios sobre o estado deteriorado de seus pulmões (Jones, 1967).

A força da tradição incitava os fimatosos a empreenderem sucessivas viagens, apesar do surgimento de leis sanitárias que tentavam inibir o trânsito dos tuberculosos. No século XX, as informações registradas nas correspondências e diários dos tísicos Katherine Mansfield e Franz Kafka, e em seus respectivos diários, denunciam a rejeição ao isolamento por parte dos enfermos, que, em continuidade, preferiam buscar tratamento da saúde em variados pontos da Europa, residindo em pensões e hotéis baratos. Persistia também o fascínio pelos longos períodos de retiro nas costas do Mediterrâneo, sendo que Monte Carlo, Mônaco e a Riviera Francesa se constituíram nos últimos redutos de liberdade dos infectados que dispunham de algum amparo econômico.

Um dos exemplos mais extremados da ânsia de recuperar a saúde por meio de contínuas mudanças de ambiente geográfico é encontrado na trajetória da vida tuberculosa do poeta António Nobre (1982). Diagnosticada a infecção no ano de 1894, o autor de Só abandonou Portugal para buscar socorro clínico na Suíça, alternando períodos de tratamento em Davos-Platz e Clavadel.

Receando piora de saúde, o poeta sonhou instalar-se nas ilhas Canárias, mas em vez disto, percorreu a Itália e, na seqüência, regressou à Suíça, vivendo alguns meses em Genebra e Lausane. Pouco tempo demorou para o tuberculoso novamente pôr-se em marcha, retornando a Portugal, onde vagou por várias regiões em busca de auxílio econômico, sendo expulso de hotéis que não aceitavam hóspedes consuntivos, perseguindo médicos e charlatães que acenavam com drogas miraculosas, ocultando de quase todos os amigos a verdadeira enfermidade que o minava. 
Desencantado, António Nobre novamente desejou viajar, escolhendo a África do Sul como alvo, mas indo para Nova Yorque e, com isto, aproveitando as benesses do “Dr. Oceano (...) o melhor médico do mundo” (Nobre, 1982:197). Porém, a permanência na América do Norte foi breve, rumando o poeta para a ilha da Madeira, onde, pela vez única, sentiu-se melhor, porque em companhia de outros tísicos lusitanos.

Sob a desculpa do rigor do clima insular, o poeta estabeleceu-se novamente na Suíça e de lá partiu para Londres e Paris e, em continuidade, uma vez mais buscou abrigo nos sanatórios e nas pensões suíças. Praticamente abandonado pelos parentes mais próximos, sem dinheiro e desesperançado, Nobre valeu-se de sua pátria como refúgio derradeiro, falecendo logo depois. Corria o ano de 1900 e com ele os 'males de Anto’ chegaram a termo.

A persistência pela vida em movimento adotada por uma vasta legião de infectados manteve-se ativa mesmo durante a era em que predominou o isolamento hospitalar como forma de tratamento e segregação dos tuberculosos. A consulta a vários guias de viagem revela que os editores destas obras assinalavam meticulosamente as estações de cura, informando os preços cobrados pelos hotéis, pensões e sanatórios que acolhiam enfermos, assim como as farmácias e os médicos dispostos a atender os tísicos. Sob o pretexto de desfrutar férias longe do abrigo doméstico, parece que se tornou comum os infectados ocultarem as temporadas passadas nas estações climatoterápicas, anunciando o retiro como simples período de descanso da agitação metropolitana.

\section{Nascimento dos Sanatórios}

A era sanatorial de atendimento aos fimatosos abriu-se no ano de 1854, quando o médico tuberculoso Hermann Brehmer inaugurou a primeira instituição especializada no tratamento de pectários, localizada nas montanhas da Silésia. Alguns anos depois, o clínico Peter Dettweiler instalou outra casa de saúde em Falkstein, nas montanhas Taurus, para tratar de si próprio e de outros infectados.

A premissa que orientou Brehmer e Dettweiler para a retomada da antiga proposta de ‘cura nas alturas’ residia na suposição segundo a qual inexistia casos de tísica entre os habitantes das montanhas. Em conseqüência, os médicos alemães concluíram que a tuberculose era resultado da circulação precária do sangue no coração e nos pulmões, sendo que a permanência dos consuntivos nas regiões altas revitalizaria as funções orgânicas em geral e, em especial dos pulmões, viabilizando a cura dos contaminados.

Inicialmente, Brehmer e Dettweiler prescreveram exercícios físicos vigorosos para os seus pacientes, tentando estimular mais ainda o funcionamento do trato respiratório. Mas, pouco tempo depois de instituída, esta orientação teve de ser abandonada, porque os facultativos perceberam que tal prática favorecia a ocorrência de hemoptises, debilitando ainda mais os pacientes pulmonares.

O desdobramento do conhecimento clínico-epidemiológico sobre a tísica associado à disseminação de sanatórios nas regiões de altitude de toda a Europa permitiram que, no final do século XIX, ganhassem força os movimentos oficiais de combate à Peste Branca. 
Se a Inglaterra foi o berço da concepção segundo a qual a doença poderia ser limitada por meio da atuação dos dispensários, o modelo germânico chamou mais a atenção, já que o governo alemão dirigiu desde 1892 a instalação de uma rede sanatorial, custeada pelos fundos criados pelos trabalhadores. Em conseqüência, vários países europeus centraram recursos na campanha pela criação de casas de saúde franqueadas ao proletariado, alegando que a tísica fazia grande número de vítimas entre os extratos mais pobres da população. Sob a ameaça de que a própria espécie humana corria risco de extinção pela Peste Branca, médicos e leigos se irmanaram, cobrando urgentes medidas oficiais contra o alastramento da infecção.

Neste contexto, as concepções vigentes desde o final do século passado instruíram entendimentos alarmantes sobre a Peste Branca e suas vítimas. A moléstia expandia-se em definição, concretizando-se ao mesmo tempo como causa e produto dos desarranjos que feriam o tecido coletivo.

O eugenista italiano Attillio Cevidalli, por exemplo, foi um dos intelectuais que, ao estudar os tísicos internados nas prisões e nos hospícios, inverteu a ordem dos fatores, concluindo que a toxina tuberculosa fazia com que os fimatosos agissem contra os valores básicos da sociedade e que, portanto, eram encarcerados nas cadeias e nos manicômios. Prosseguindo em seus ensinamentos, o intelectual italiano ganhou seguidores ao pontificar a urgência do combate à moléstia, explicando que a redução do grupo de infectados - ou o enclausuramento dos pectários - repercutiria no ambiente social, fazendo diminuir o número de atentados contra a ordem pública (Cevidalli, 1928).

As ciências sociais norte-americanas também caminharam nessa mesma linha de raciocínio. Em um dos principais textbooks publicados nas primeiras décadas do século XX, Alfred Queen e Delbert Mann (1925), sociólogos da Universidade de Chicago, faziam coro às idéias de Cevidalli, acrescentando que o indivíduo contraía a infecção pulmonar devido ao desregramento da vida cotidiana - inclusive pela aversão ao trabalho - sendo que a tuberculose apresentava-se como último recurso aos que buscavam fugir de seus compromissos com a sociedade.

A partir destas constatações, a intervenção no problema representado pela Peste Branca tornou-se um 'dever social' de todos os cidadãos, favorecendo as críticas aos governos nacionais que se mostravam apáticos frente à ameaça sanitária. Na França, onde a luta contra a moléstia tardou a ganhar impulso, inúmeras foram as vozes que reclamaram contra a inexistência de sanatórios destinados ao atendimento dos contaminados mais carentes. Por isso, no ano de 1902, um médico socialista aconselhava a França a seguir o exemplo germânico, cobrando do Estado e da burguesia a 'obra patriótica’ de criação de sanatórios populares (Boureilli, 1901).

O resultado destas campanhas ativadas nacionalmente consistiu na criação de uma rede de casas de saúde especializadas no continente europeu. A partir de então, os sanatórios transformaram-se no ambiente próprio dos consuntivos e no espaço constitutivo do saber tisiológico.

Os enfermos, por sua vez, mantinham uma atitude contraditória em relação a estes nosocômios. Espaços organizados para a cura da tuberculose, os sanatórios também representavam a exclusão do cotidiano dos sadios. 
Nas primeiras décadas do século XX, Thomas Mann, que acompanhou a esposa tísica durante seguidos internamentos em sanatórios suíços, e Paul Gadene, ele próprio tuberculoso, dentre outros, foram escritores que conviveram intimamente com a moléstia, denunciando os padecimentos dos contaminados isolados nos hospitais das montanhas. Isto porque a concepção segundo a qual os fimatosos eram crivados de vícios produzidos ou pelo menos exponenciados pela ação bacilar, impunha que a clínica administrasse idealisticamente os sanatórios segundo o modelo gerenciador da vida em caserna.

Em nome da preservação da raça, como queria o Dr. Banu (1939), ou da defesa moral, como advogava o Dr. Tartarin (1902), o diretor apropriado de uma casa de saúde era o que tivesse longa experiência como médico militar e o melhor dos pacientes era o soldado tuberculoso, pois um sabia ditar ordens e o outro obedecer rigorosamente as normas impostas pelos seus superiores.

A apologia da robustez física como indício da saúde moral e física, por contraste, situou a magreza corpórea e a fragilidade física como símbolos da doença e do comprometimento moral. A redefinição médica e social do tuberculoso, na segunda metade do século XIX, favoreceu a marginalização do infectado, sinalizando o isolamento sanatorial como destino último dos enfermos do peito. Neste contexto, ganhou aceitação ampla a 'identidade virtual' negativa e assustadora atribuída aos tísicos. Tal fenômeno não só permitiu a multiplicação dos tratamentos estigmatizadores impostos aos consuntivos, mas também abriu novas oportunidades para reiteração dos valores e dos comportamentos ‘saudáveis’ que deveriam reger a sociedade moderna.

No encerramento do século XIX e nas primeiras décadas do século XX, a Peste Branca e seus tributários dispunham de explicações biológicas e sociais que, guardando coerência, mostravam-se complementares. Estabeleciam-se assim os meandros possíveis da história dos infectados. Uma história que teve desdobramentos inclusive no contexto brasileiro. 


\section{3 \\ Administração Sanitária e Tuberculose no Brasil}

A presença da tuberculose no Brasil persiste ainda como tema repleto de dúvidas quanto a sua origem. Os poucos estudiosos que pesquisaram o pretérito sanitário nacional parecem convergir para uma visão paradisíaca sobre o perfil epidemiológico das populações pré-cabralinas, repetindo as observações registradas pelos primeiros visitantes da colônia. A partir disso, a historiografia consagrou a versão de que, antes da chegada dos europeus, os agrupamentos indígenas desfrutavam de saúde perfeita, sendo assolados por raras patologias, todas elas de pouco risco para a vida.

Em continuidade, os médicos Afranio Peixoto, Lourival Ribeiro e Lycurgo Santos Filho, dentre outros, negam a existência da tísica junto às populações primitivas da América e em especial entre as tribos brasileiras, no momento que antecedeu ao contato com os conquistadores brancos. O antropólogo Thales de Azevedo (1941) talvez tenha sido o único pesquisador brasileiro a destoar dessa tendência, lançando dúvidas sobre a inexistência da consunção entre os indígenas no período anterior ao ano de 1500 sem, contudo, chegar a qualquer conclusão mais conseqüente.

A proposta de uma América edênica, entretanto, tem sido contrariada por inúmeros estudiosos estrangeiros. Aristides Moll (1969) defende a tese que coloca a tuberculose como moléstia conhecida pelos autóctones americanos muito antes de 1492, assinalando que os Incas haviam batizado a letal enfermidade com o nome de chaki onkoy. Outro pesquisador, o francês Mirko Grmek (1983), também aponta para a presença da tísica no ‘Novo Mundo’ no período que antecedeu a invasão européia. Com base em dados oferecidos pela paleopatologia, Grmek assinala que a infecção pulmonar apresentava-se como evento corriqueiro nos centros urbanos pré-colombianos, fazendo poucas vítimas nos agrupamentos de tamanho reduzido e que mantinham escassos contatos com as tribos maiores.

O certo, porém, é que a moléstia firmou-se como uma das principais causas de óbitos entre os indígenas a partir do século XVI, fenômeno que sugere a pouca intimidade grupal com o bacilo de Koch. A provável condição de virgin soil para a moléstia consuntiva - isto é, de comunidade cuja história biológica não incluía a tuberculose fez com que os índios se tornassem vítimas indefesas da Peste Branca, resultando no desaparecimento de inúmeras organizações tribais e, na continuidade, situando a tísica como uma das principais marcas da epidemiologia continental. 
No contexto colonial brasileiro, salienta-se que os primeiros sacerdotes que aqui aportaram vieram não só para trabalhar por ‘Deus e Sua Majestade’, mas também para tratar da saúde comprometida pelo mal consuntivo. Não faltam afirmações de que os padres fimatosos Manoel da Nóbrega e José de Anchieta tenham sido os primeiros disseminadores da doença entre os índios, contribuindo para o decréscimo populacional entre os tupis-guaranis catequizados.

Em agosto de 1557, o jesuíta Manoel da Nóbrega escrevia aos seus superiores pedindo novos apóstolos para atuarem na Terra de Santa Cruz, invocando seu estado de saúde como motivo do rogo:

a mim devem-me já de ter por morto, porque ao presente fiquo deitando muito sangue polla boca. O medico de quá hora diz que hé vea quebrada, ora que hé do peito, hora que pode ser da cabeça: seja donde for, eu o que mais sinto hé ver a febre ir-me gastando pouco a pouco. (Leite, 1957:404) ${ }^{1}$

A recorrência ao africano escravizado permitiu que um novo grupo provavelmente não tuberculinizado chegasse ao Brasil, sendo que os negros, em pouco tempo, tornaram-se as principais vítimas da fatal tísica. As condições de vida e de trabalho impostas aos cativos favoreceram a disseminação da moléstia entre os africanos e seus descendentes brasileiros, induzindo vários pesquisadores a pontificarem que a tuberculose imperava entre os negros pelas características próprias da biologia racial.

Outros estudiosos, entretanto, preferem creditar o alastramento da fimatose entre os negros ao excesso de trabalho, à dieta alimentar precária, ao alcoolismo e também ao consumo de maconha (Santos Filho, 1977). No século XIX, a consunção continuou a se alastrar entre a comunidade escravizada. Na pintura intitulada Mercado da Rua do Valongo, Debret retratou um grupo de negros abatidos, apáticos e macérrimos, elementos que permitiram a um tisiologista reconhecer que tais personagens apresentavam traços típicos de infecção pelo bacilo de Koch.

A continuidade dos estragos atribuídos à moléstia pulmonar passou a chamar a atenção das autoridades públicas, especialmente após o estabelecimento da família real portuguesa no Rio de Janeiro. A doença que tanto os leigos quanto os clínicos denominavam de 'fraqueza do peito', 'chaga nos bofes' e 'sangue pela boca' aumentava o número de seus tributários, exigindo respostas dos especialistas na saúde urbana.

O médico Francisco de Mello Franco (1829) foi um dos primeiros esculápios que examinou a 'febre héctica' no contexto nacional, assinalando que o morbus anualmente roubava um significativo número de vidas da população brasileira. Reproduzindo os ensinamentos ministrados pela medicina européia do tempo, o Dr. Mello Franco (1829:113) confundia a tuberculose com a febre resultante da infecção, concluindo que o melhor tratamento disponível para o pectário baseava-se no quinino, no ópio e também em sucessivas sangrias, pois o clínico acreditava que "no sangue possa existir a principal causa excitante da febre”.

As dificuldades hipocráticas em limitar o avanço da tísica no terreno da Corte fazia com que os doentes recorressem a uma multiplicidade de remédios, na tentativa de recuperar a saúde. Além das sangrias que eram praticadas, inclusive pelos cirurgiões negros que trabalhavam nas calçadas, os cariocas faziam uso de alguns elementos da 
flora nativa, como por exemplo, chás preparados com folhas de goiabeira, jataí e cipóchumbo, ingerindo também grandes quantidades de mocotó e de leite de cabra e de jumenta, como reconstituintes pulmonares.

A procura pelas enfermarias hospitalares era evitada, não só devido ao medo que os recintos nosocomiais inspiravam naquele período, mas sobretudo pela escassez de leitos, fato que ditava a demora na obtenção de assistência médica. Quando a chance aparecia, os fimatosos eram instalados em camas avizinhadas aos catres das vítimas de outras patologias, favorecendo o mortal intercâmbio de moléstias que geralmente levavam a óbito os hóspedes das casas de saúde. Por isso, em 1840, a Santa Casa do Rio de Janeiro estabeleceu uma enfermaria exclusiva para o atendimento dos doentes do peito, originando-se daí o interesse pela construção de um hospital relativamente afastado do centro urbano e destinado a receber unicamente os pacientes tuberculosos.

Somente em 1886 foi que as autoridades sanitárias do Império buscaram seguir, pelo menos parcialmente, o modelo preconizado na Europa, fazendo entrar em atividade o primeiro nosocômio especializado na assistência aos tísicos, localizado no subúrbio de Cascadura. A vida do hospital, porém, prolongou-se por apenas duas décadas, momento em que a unidade foi desativada, alegando-se a escassez de donativos públicos e privados como motivo causador da suspensão das atividades médicas (Ribeiro, 1956).

De qualquer forma, a partir de meados do século XIX, praticamente todas as famílias cariocas contavam com pelo menos um de seus membros assaltado pela corrupção do peito. Espelhando os receios produzidos pela ampla disseminação da moléstia, o clínico João Vicente Torres Homem (1882) ocupou muitas de suas preleções na Faculdade de Medicina do Rio de Janeiro com a análise dos danos individuais e coletivos causados pela tísica.

Quando o Dr. Torres Homem publicou a síntese dos cursos que havia ministrado nas duas décadas anteriores, o médico enfatizou que nunca a tuberculose havia feito tantas vítimas no território brasileiro quanto naquele período, declarando ainda que a Peste Branca se transformara no principal flagelo sanitário que ameaçava os habitantes da capital do Império.

O interesse em esclarecer os elementos determinantes do mal consuntivo levaram o catedrático da academia médica a buscar apoio nas doutrinas vitalista e miasmática vigentes no início da centúria para ensinar que o clima quente e úmido do Rio de Janeiro mancomunava-se com os mecanismos da hereditariedade, com o alcoolismo e com o aleitamento mercenário para propiciar a rápida expansão do reino da tísica. Neste encaminhamento de idéias, o Dr. Torres Homem mostrou-se pouco convencido das recentes descobertas microbianas, observando que "Entre o povo brazileiro, principalmente nas camadas sociais menos esclarecidas, está enraizada a opinião de que a phthisica pulmonar é muito contagiosa” (Torres Homem, 1882:358).

O pressuposto da fimatose configurar-se como moléstia disseminada de um indivíduo para outro era indicado como elemento próprio da cultura tradicional dos povos ibéricos. Entretanto, a multiplicação dos debates realizados na Europa acerca da validade das propostas pastorianas parece que plantou uma semente de dúvida nas exposições do professor de Clínica Médica que, tocado pela indecisão, buscou conciliar seus posicionamentos com alguns pontos da inovadora medicina de Pasteur: 
Quem sabe se o ar expirado pelo phthisico não contem parcellas nocivas, que, sendo absorvidas pelos pulmões de um individuo são, podem n'elles provocar um trabalho inflammatorio lento e gradualmente destruidor! Quem sabe se o suor do phthisico em contacto com a pelle de quem está bom é absorvido pouco a pouco e serve de vehiculo á diathese tuberculosa! Quem sabe se este mesmo suor, transformado em vapor aquoso pela evaporação, não entra no organismo de quem convive com o doente, por meio da inhalação pulmonar! (Torres Homem, 1882,: 359-361, v. 1)

Pouco mais de uma década depois da publicação do texto das aulas ministradas pelo Dr. Torres Homem, a comunidade médica nacional revelava-se ainda pouco resoluta em aceitar os pressupostos microbianos. Repetindo o movimento que ocorria em escala mundial, a escola médica do Rio de Janeiro postava-se como guardiã incondicional da tradição hipocrática, sendo que, no ano de 1894, raros eram os lentes daquela faculdade que assumiam a tuberculose como enfermidade de caráter infecto-contagioso. Os lentes mais arrojados expressavam cautela, pontificando que a Peste Branca era causada tanto pela inflamação dos tecidos quanto pela ação bacilar, conseguindo com isso mostrarem-se inteirados dos recentes debates que vinham agitando a medicina positivista européia e, ao mesmo tempo, fugirem do confronto com os decanos da clínica e da Saúde Pública nacionais (Freitas, 1940).

No resto do país, o mesmo clima de indecisão bafejava as exposições especializadas. Em São Paulo, por exemplo, o cirurgião Luiz Philippe Jardim (1894), diretor do Hospital Militar, ensinava que a consunção era fruto da determinante hereditária e também do contágio. Ainda segundo o Dr. Jardim, o principal meio de infecção era o intercurso sexual, alegando que suas experiências apontavam para as mucosas genito-urinárias como o principal reservatório do bacilo identificado por Koch.

\section{A Tuberculose como Questão Pública}

O advento do regime republicano incentivou os debates que resultaram na elaboração de um projeto nacional modernizante e calcado nos modelos representados pelos chamados ‘países civilizados'. Neste processo, a Saúde Pública foi considerada um dos principais setores onde a administração governamental deveria intervir, já que, segundo os ideólogos do período, o padrão sanitário predominante no momento imperial depunha contra a qualidade da 'raça brasileira', minando o espírito coletivo compromissado com os interesses nacionais. A definição do Brasil como um 'vasto hospital' exigia a imediata intervenção sanitária, estabelecendo as possibilidades e os limites da 'regeneração' da força de trabalho autóctone, assim como a atualização disciplinadora da sociedade brasileira.

A intervenção oficial na esfera higiênica, entretanto, realizou-se basicamente nos espaços urbanos situados nas unidades mais ricas da federação, especialmente as metrópoles carioca e paulista e, secundariamente, outras capitais estaduais que tinham sofrido sensível aumento populacional nas últimas décadas do século XIX, tais como Recife, Salvador e Porto Alegre. 
A necessidade de limitar os prejuízos causados pelo conjunto de enfermidades que feria o corpo social tinha como elemento incentivador a urgência de dinamizar a circulação de homens e mercadorias, itens vitais para o bom funcionamento de uma economia com base no esquema agrário-exportador. Isto porque as doenças que assolavam as urbes brasileiras e especialmente as áreas portuárias inibiam a chegada de novos contingentes de imigrantes, afugentando igualmente os negociantes que buscavam estabelecer elos econômicos com o país.

Nesta circunstância, o governo federal e as autoridades estaduais buscaram conter o avanço das endemias e das epidemias que periodicamente ameaçavam o cotidiano das metrópoles, dispensando verbas e servidores para o combate da febre amarela, da varíola, da peste bubônica e da febre tifóide.

$\mathrm{O}$ fato de a Peste Branca ser reconhecida como uma das patologias que mais ceifava vidas no espaço citadino não foi suficiente para motivar os administradores da Primeira República a elaborar dispositivos de combate a uma moléstia que, se amplamente disseminada, ainda não dispunha de estratégias preventivas e curativas de aceitação geral pela corporação médica. Assim, diferentemente das demais enfermidades que assolavam as cidades, a tísica não contou com as atenções e os recursos oficiais, fazendo com que a sociedade assumisse as tarefas de criação e de patrocínio das instituições que tinham o objetivo de prevenir o contágio e amparar os tuberculosos pobres.

A aparente apatia governamental referente à doença dos pulmões foi quebrada no ano de 1907, quando Oswaldo Cruz propôs ao Congresso Nacional a aprovação de uma lei que estabelecia a obrigatoriedade clínica de notificação dos casos de tuberculose, a criação de um serviço especializado na enfermidade e ainda a ocupação de um inexistente sanatório que o higienista acreditava que a Marinha havia construído em Campos do Jordão.

O prestígio de médico que havia saneado o ambiente carioca e a autoridade emanada do cargo de diretor-geral do Departamento Nacional de Saúde não foram suficientes para que os políticos apadrinhassem a proposta cruziana. Ainda impressionados com as cenas que marcaram a Revolta da Vacina, os representantes do povo rejeitaram o projeto elaborado pelo comandante do Instituto de Manguinhos.

\section{A Proposta Assistencial Paulista}

Coube ao estado de São Paulo a função inauguradora do movimento social de combate à tuberculose. A condição de área mais rica do país somou-se ao fato da terra bandeirante conviver com a moléstia do peito desde o início da ocupação da capitania, quando a 'peste de priorizes' tornou-se doença comum nos redutos indígenas, mantendo-se como algoz constante da gente paulista.

O incremento da imigração européia para a 'terra do café' deu nova dimensão à ameaça tísica. Por isso, no ano de 1887, o inspetor-geral da Higiene da Província chamou a atenção para o número de doentes pulmonares que existiam em São Paulo, informando que estes procuravam a terra bandeirante pela fama terapêutica dos ares locais (Arruda, 1936). 
A tuberculose se apoderava a passos largos da 'metrópole do café', fazendo mais de quinhentos óbitos notificados no último qüinqüênio do século passado. Neste contexto, o higienista Emílio Ribas - diretor do Serviço Sanitário estadual entre os anos de 1898 e 1917 - mostrou-se sensível ao avanço da Peste Branca, convidando o clínico carioca Clemente Ferreira para transferir-se para a cidade de São Paulo e aqui iniciar a primeira campanha nacional contra a moléstia de Koch.

Os motivos que levaram o Dr. Ribas a escolher Clemente Ferreira para a tarefa em questão deveu-se provavelmente ao interesse demonstrado pelo médico carioca em combater a Peste Branca. O Dr. Ferreira havia se graduado em medicina no Rio de Janeiro, apresentando, em 1882, uma tese sobre a 'phthisica pulmonar', mas pouco depois mudou o rumo de sua especialização, dedicando-se à área que mais tarde ganharia a denominação de pediatria.

Na seqüência, o médico recém-formado encontrou colocação como assistente da clínica de moléstias infantis da Policlínica da antiga Corte, sendo que, ainda na década de 80 do século XIX, o Dr. Ferreira assinou um ensaio que analisava as qualidades climatoterápicas de Campos do Jordão e as possibilidades de organização da luta contra a moléstia pulmonar, fato que certamente despertou a atenção do diretor da Higiene paulista.

O facultativo estabeleceu residência em São Paulo em 1896, ocupando a função de 'médico de crianças' e, dois anos depois, o cargo de direção do consultório de lactantes do Serviço Sanitário estadual. Paralelamente, o clínico carioca foi incumbido de sensibilizar seus pares e os principais representantes da elite regional para a organização de um entidade filantrópica de combate à peste consuntiva.

Fruto dos esforços conjugados do funcionário e do diretor-geral da Saúde Pública, no mês de julho de 1899, surgiu a Associação Paulista de Sanatórios Populares para Tuberculosos, a qual teve Clemente Ferreira como único presidente, desde a sua fundação até 1945, quando o patrono dos tisiologistas de São Paulo, muito adoentado, afastou-se da administração da entidade.

Os objetivos iniciais desta instituição seguiam de perto as propostas expressas na carta de fundação da Verein für Volksheilstätten, sediada em Munique. Com isso, o Dr. Ferreira buscou reproduzir no contexto nacional a experiência germânica, empenhando os primeiros anos de vida da Associação no levantamento de recursos suficientes para a construção de um sanatório popular em Campos do Jordão, de um dispensário na cidade de São Paulo e ainda para a organização de um movimento educativo e de prevenção ao contágio fimatoso.

Apesar dos esforços do Dr. Ferreira para que a entidade contra a tísica cumprisse seu programa de ação, em pouco tempo a luta contra a Peste Branca deixou de ser novidade, fazendo com que as doações filantrópicas se tornassem cada vez mais escassas. A disponibilidade de recursos extremamente limitados exigiu que, já no primeiro ano do século passado, a Associação corrigisse seus compromissos, centrando seus trabalhos no estabelecimento de um dispensário especializado, o qual deveria seguir a pluralidade de ações preconizada pelo médico e nobre escocês Robert Philip, idealizador dos primeiros postos de atendimento à parcela do proletariado atingida pelo bacilo consuntivo. 
Na série de alterações, a partir de 1903, a organização ferreiriana foi rebatizada com a designação de Liga Paulista Contra a Tuberculose, a qual adotou os serviços dispensariais como eixo central da assistência aos infectados. Apesar disso, a concepção que estipulava o isolamento dos consuntivos em recintos sanatoriais manteve-se como ideal máximo da instituição, permanecendo como matéria crítica no relacionamento da Liga com a administração pública estadual.

Nesta seqüência das atividades, a Liga Paulista Contra a Tuberculose rompeu relações com o Serviço Sanitário, colocando em campos opostos os diretores de ambos os órgãos. Atraído para São Paulo para atuar junto à administração da Saúde Pública, o Dr. Ferreira mostrou-se sempre reticente em reconhecer o apoio que o Dr. Ribas oferecia à Liga, alijando o nome da instituição governamental dos relatórios, palestras e artigos que publicava sobre os esforços regionais contra a disseminação da Peste Branca.

Apesar da pouca clareza dos motivos que alimentaram o conflito entre os dois esculápios, suspeita-se que a continuidade de atritos deveu-se principalmente à pretensão personalista do 'médico de crianças'. Desde o surgimento da Associação, o clínico levantou a bandeira da campanha que visava a construir um sanatório popular em Campos do Jordão, o qual deveria ser financiado pelo governo estadual, mas ficar subordinado ao movimento filantrópico e não ao Serviço Sanitário.

Emílio Ribas, por sua vez, opôs-se a essa proposta, designando dois de seus mais fiéis assessores para a elaboração de um projeto relativo ao estabelecimento de uma casa de saúde especializada no estado de São Paulo. O resultado foi a publicação, no ano de 1899, de um extenso documento assinado pelos médicos Victor Godinho e Guilherme Alvaro em cuja página de apresentação o Dr. Ribas advogava que o Brasil deveria imitar o exemplo dos países em que o gerenciamento da luta contra a tuberculose era encargo exclusivo da alta direção do Serviço Sanitário.

No relatório publicado pela Saúde Pública, informava-se que a tísica era responsável por não menos que 7\% dos óbitos notificados no estado de São Paulo, taxa que tenderia a se ampliar caso nada fosse feito para limitar a disseminação da doença pulmonar. Alegando que a infecção consuntiva era moléstia facilmente curável, os Drs. Godinho e Alvaro acrescentaram que a administração estadual deveria instalar em regime de urgência um nosocômio especializado em Campos do Jordão, não só porque o clima das montanhas era indicado para o tratamento dos fimatosos, mas também porque o local era de difícil acesso, protegendo os sadios contra a contaminação bacilar.

Nas conclusões desse estudo, entretanto, os higienistas confessaram-se descrentes da necessária agilidade oficial em custear a construção e o funcionamento de um sanatório na Serra da Mantiqueira. Por isso, depois de preencher quase uma centena de páginas onde o hospital para tuberculosos constituía-se principal tema, os médicos do Serviço Sanitário surpreenderam ao concluir que: “O phthisico póde curar-se em sua casa, desde que a transforme em um pequeno Sanatorio, ou desde que faça e use nella tudo o que teria de fazer e usar no Sanatorio”(1899:98).

A intromissão dos inspetores sanitários oficiais nos debates sobre a construção de uma casa de saúde para os tísicos paulistas parece que desagradou o Dr. Ferreira, que insistia que a luta contra a tuberculose deveria ser comandada exclusivamente pela 
Liga que dirigia. Em conseqüência, o tisiologista respondeu à proposta oficial por meio da composição de um outro relatório, datado do ano de 1900.

Nesse documento, parece que Clemente Ferreira tentou definir as áreas de influência da Liga Paulista contra a Tuberculose e do Serviço Sanitário: apesar de reclamar a paternidade da idéia de instalação de um hospital em Campos do Jordão, o Dr. Ferreira abriu mão desta iniciativa, atribuindo ao Estado a tarefa de erguimento e administração do nosocômio, exigindo em troca a construção de uma estrada de ferro que ligasse a estação de cura das montanhas com o Vale do Paraíba. A Liga, por sua vez, ficaria com o compromisso de patrocinar os serviços dispensariais na cidade de São Paulo, assim como levar avante o projeto de criação de um orfanato para os filhos dos consuntivos e também estudar a possibilidade de estabelecimento de um sanatório nas cercanias da capital paulista.

Mesmo que cada palavra assinada pelo clínico deixasse a impressão que o médico buscava se reconciliar com a Saúde Pública estadual, o Dr. Ferreira não se furtou de criticar uma vez mais seus superiores do Serviço Sanitário, respondendo à proposta oferecida, no ano anterior, pela instituição oficial:

O isolamento domiciliar é, porém, uma illusão, principalmente nas classes pobres. (...) Nem pavilhões, nem isolamento methodico; a maior parte succumbe mesmo em seus domicilios á mingua de recursos therapeuticos, baldos de um tratamento hygienico efficaz e com plena liberdade de infeccionar todos que com elles cohabitam.(...) O tractamento proficuo dos tuberculosos é uma utopia nas condições em que nos achamos. (1900:5)

Concomitantemente ao pronunciamento do diretor da Liga Paulista, o comandante do Serviço Sanitário enviou o Dr. Victor Godinho à Europa, para que visitasse os principais sanatórios da Alemanha, Suíça e França e se familiarizasse com os compromissos básicos que regiam as atividades e a rotina dos hospitais que atendiam os fracos do peito. Depois de permanecer por mais de um ano no 'Velho Mundo', o assessor dileto de Emílio Ribas retornou ao Brasil, apresentando um novo relatório oficial que, como o anterior, contou com uma edição de dez mil exemplares, sendo distribuído prioritariamente entre os grupos de políticos do estado, até mesmo para os vereadores dos menos expressivos municípios do estado (Godinho, 1902).

Neste documento, o Dr. Godinho retomou quase todas as idéias que haviam sido examinadas no texto preparado em 1899. Uma das raras novidades constantes deste segundo relatório governamental refere-se à proposta de criação de sanatórios pré-fabricados e de teto móvel, visando assim não só a facilitar o aproveitamento da ação desinfetante dos raios solares como também a viabilizar a rápida transferência da casa de saúde de um local para outro. O estranho de tudo: tal idéia não foi resultado do estágio que o médico brasileiro cumpriu na Europa, mas sim produto de um projeto elaborado no Brasil e assinado pelo próprio Dr. Emílio Ribas.

Mais do que a ausência de sugestões que eventualmente tivessem sido colhidas nos centros tisiológicos europeus, o que chama a atenção neste texto que leva a marca do Serviço Sanitário é a aparente redefinição dos postulados que impregnavam os discursos oficiais anteriores ao ano de 1902, os quais reiteravam que o melhor local para a instalação de um sanatório consistia na área de Campos do Jordão. 
Para a surpresa de todos, a partir de então, o Dr. Godinho passou a afirmar que a tentativa de instalação de um hospital na Serra da Mantiqueira era uma "empreza enviavel”, indicando os arredores da capital dos paulistas e "até o município de São Roque” (1902:56) como regiões ideais para a instalação de uma unidade de isolamento dos tísicos pobres. Com isso, a equipe do Dr. Ribas apropriou-se das sugestões apresentadas dois anos antes por Clemente Ferreira, esclarecendo que o estabelecimento de um sanatório na Serra da Mantiqueira era uma idéia economicamente desarrazoada:

pensamos que a excellencia, não discutida nem discutível, do clima de Campos do Jordão, não basta para que o estado de São Paulo emprehenda a construç̧ão de uma estrada de ferro para aquellas regiões, só para que se construa o Sanatorio para tuberculosos. (Godinho, 1902:72)

Transposta mais de uma década desde o início do conflito higienista, os jornais anunciaram a organização de uma empresa que tinha como objetivo construir um caminho de ferro que ligaria o distrito de paz de Campos do Jordão, na comarca do município de São Bento do Sapucaí, à cidade valeparaibana de Pindamonhangaba, acrescentando que a mesma companhia pretendia estabelecer uma vila sanitária e um sanatório para tuberculosos na região serrana.

Pouco tempo depois, o Congresso Estadual aprovou o projeto, concedendo aos empreendedores o direito de explorar uma faixa de 15 quilômetros de cada lado do eixo da linha férrea, garantindo também os juros de $5 \%$ sobre o capital inicial da companhia, o qual era inicialmente de 3 mil contos, logo em seguida aumentado para 4 mil. Os concessionários da empresa organizaram então a Sociedade Anonyma Estrada de Ferro Campos do Jordão, aparecendo como principais acionistas os nomes de Emílio Ribas e de Victor Godinho, sendo que o primeiro era natural de Pindamonhangaba, local onde era proprietário de extensas glebas de terra.

A novidade chegou aos ouvidos do Dr. Ferreira, que se incumbiu de disseminar ainda mais a notícia de o governo ter concedido os direitos de construção e exploração da estrada de ferro e do sanatório aos dois funcionários que, anos antes, tinham persuadido as autoridades a não levar avante tais projetos.

De maneira sutil e persistente, o diretor da Liga Paulista abordou o caso por repetidas vezes, passando a mencionar com freqüência o nome do Serviço Sanitário, inclusive no decorrer de seu pronunciamento na Conferência Internacional sobre a Tuberculose, realizada em Londres. No pronunciamento do médico brasileiro, tanto Ribas quanto Godinho estavam recebendo "favores especiais” do governo para criar um sanatório particular e uma vila sanitária que gerariam “um bom lucro” aos seus proprietários (Ferreira, 1913:5).

Por situações como esta, a Liga Paulista Contra a Tuberculose foi relegada a um isolamento que estimulou seu diretor a se lançar em uma campanha que associava a realização de obras de apoio aos pectários com a contínua cobrança de medidas oficias e filantrópicas para a limitação da Peste Branca. Muitas das páginas da revista Defesa Contra a Tisica - publicada irregularmente entre 1902 e 1914 e dirigida por Clemente Ferreira - foram preenchidas com a reprodução de memorandos expedidos pela Liga Paulista e encaminhados ao presidente do estado e aos responsáveis pelos hospitais 
paulistas, exigindo a instalação de sanatórios, a criação de pavilhões exclusivos para os pacientes fimatosos nas Santas Casas e a organização de serviços de desinfecção das residências onde existiam tuberculosos.

Paralelamente a isto, a Liga Paulista manteve um contínuo trabalho de divulgação dos princípios higiênicos que afastavam o perigo do contágio tísico. O Dr. Ferreira fez publicar dezenas de panfletos educativos e cartazes que visavam a orientar a população sobre a infecção, reservando para a elite intelectual contínuas palestras e conferências, nas quais eram discutidos os princípios clínicos e terapêuticos que orientavam a tisiologia européia.

Neste contexto, é fácil perceber que a seleção dos palestristas e dos temas abordados era uma tarefa exclusiva do diretor da instituição. A análise das palestras publicadas na Defesa Contra a Tisica deixa claro que alguns tópicos foram praticamente abolidos das discussões, tais como as pálidas medidas oficiais contra a enfermidade e também o papel desempenhado pela miséria econômica, pela prostituição e pelo alcoolismo na disseminação da tuberculose.

Até mesmo os recursos terapêuticos empregados pela medicina só ganhavam foro de discussão mediante a aprovação de Clemente Ferreira. No transcorrer da primeira década do século XX, o tisiologista era acirrado defensor das propriedades curativas e preventivas da Tuberculina de Koch, não sendo por acaso que muitas das reuniões públicas promovidas pela Liga Paulista versaram sobre o tema. Como exemplo, tem-se a série de palestras proferidas pelo clínico carioca Oliveira Botelho (1910), as quais foram amplamente divulgadas pela associação ferreiriana, inclusive porque reproduziam fielmente as idéias esposadas pelo presidente da instituição.

Mesmo contando com as idiossincrasias de seu diretor e com o prosseguimento dos choques entre este e a administração sanitária estadual, a Liga Paulista Contra a Tuberculose conseguiu inaugurar e manter um conjunto de dispositivos que se transformaram em órgãos modelares da luta brasileira contra a tísica.

Na seqüência de suas atividades, a Liga instalou, em 1904, o primeiro dispensário destinado ao atendimento dos fimatosos pobres, no contexto nacional. Pouco depois, foi criada a Obra de Preservação dos Filhos dos Tuberculosos Pobres, movimento apoiado pelas damas da sociedade paulista e que tinha como objetivo patrocinar a construção de um albergue para os filhos dos infectados, resultando no estabelecimento de um preventório infantil na cidade de Bragança Paulista. Na década de 20, coube ainda à Liga a construção e manutenção do Sanatório São Luiz que, localizado no município de Piracicaba, funcionou por apenas um lustro, sendo desativado, em 1931, devido à insuficiência de verbas.

Na sucessão das tarefas, a associação ferreiriana fez de tudo um pouco: educação sanitária, vigilância dos 'grupos de risco', testes com as drogas anunciadas como curativa dos pulmões, formação de tisiologistas, cirurgias torácicas, assistência clínica e amparo social. Neste contexto, nem sempre a sociedade paulistana percebeu com bons olhos as atividades desenvolvidas pela Liga, especialmente no que se referia ao funcionamento do ambulatório para tuberculosos em um prédio alugado e localizado na rua Líbero Badaró, no coração da Paulicéia. 
Movido pelos protestos dos ocupantes sadios do edifício que abrigava o posto de atendimento aos fimatosos, Clemente Ferreira conseguiu doações suficientes para construir um prédio próprio para acomodar todas as atividades desempenhadas pela Liga, em um terreno localizado na parcela inicial da rua da Consolação. Imediatamente, os moradores da área, motivados pela tisiofobia reinante, organizaram um movimento contrário à transferência da unidade de tratamento dos tuberculosos para as proximidades da Vila Buarque e da Santa Cecília, situação que exigiu a interferência de várias comissões que passaram atestados nos quais declaravam que o dispensário não representava perigo contagioso para os moradores daquela parte da cidade.

Mas, tudo o que vinha sendo feito em favor dos pectários ainda era pouco para conter o avanço da Peste Branca no estado de São Paulo. Apesar dos esforços coordenados pela Liga e ainda a entrada em funcionamento do Sanatório Vicentina Aranha - inaugurado em 1924, em São José dos Campos -, no encerramento da década de 20, a tuberculose estava amplamente disseminada na região, especialmente na cidade de São Paulo.

Na capital bandeirante, onde a notificação clínica dos óbitos era muito mais freqüente que no resto do estado, os índices de morte pela consunção apresentavamse altos e estáveis, sendo que no primeiro ano do século passado a taxa de mortalidade pela tísica era de 86,7 por 100 mil habitantes, enquanto em 1929, o mesmo índice assinalava 79,6 (Mascarenhas, 1953).

Neste último momento, Clemente Ferreira denunciou as dificuldades de sobrevivência da Liga Paulista, informando que a elite local pouco contribuía com donativos para a luta contra a moléstia consuntiva. Na ausência da generosidade dos 'ricos', o clínico disse ter encontrado apoio junto aos 'mais humildes', os quais patrocinavam as atividades da Liga mediante a aquisição dos 'selos sanitários', instituídos no Brasil pelo próprio Dr. Ferreira, no início da década de 20, pouco tempo depois de terem aparecido na Europa.

Confessando que era "transparente a pouca sympathia que desperta a cruzada contra o inimigo mais temeroso da raça humana”, o tisiologista levantou sua voz seguidamente para acusar a negligencia governamental frente à moléstia que corrói os pulmões. No Relatório da Liga Paulista contra a Tuberculose, Ferreira (1931:3) assim expôs a questão que tanto o torturava:

Por seu turno a acção official tem sido até aqui por demais apagada, para não dizer nulla, e entretanto indispensavel se faz uma campanha de tão grande porte, no manejo de um problema de tanta complexidade e polymorphismo, a assistência financeira efficaz do Poder Publico, pois, como já affirmou Calmette, a solução do problema da tuberculose é uma questão de dinheiro.

\section{Brasil e o Modelo Paulista}

Apesar de todas as dificuldades de sobrevivência e atuação registradas na trajetória da Liga Paulista Contra a Tuberculose, a iniciativa bandeirante serviu durante toda a República Velha como paradigma inspirador das demais campanhas estaduais 
centradas na Peste Branca. A criação de uma entidade de combate à doença pulmonar em São Paulo foi reproduzida em outras unidades da federação que, de regra, apontavam as ações comandadas por Clemente Ferreira como responsáveis pelo presumível baixo índice de mortalidade consuntiva na capital industrial do país.

Assim, exagerando nos dados apresentados, o Serviço Sanitário de Pernambuco fez constar em seu relatório do ano de 1926, uma série de dados estatísticos em que ficava assegurado que São Paulo era a cidade 'menos assolada' pela tuberculose do país, informando também que a capital paulista se incluía entre as mais salubres metrópoles do mundo, com um coeficiente de óbitos por tuberculose bem inferior aos de Montevidéu, Paris, Viena, Roma e Madri.

De qualquer forma, os governos federal e estaduais mantiveram-se pouco sintonizados com os movimentos regionais de combate à tísica, mesmo no tocante ao Rio de Janeiro. Na capital da República, a criação da Liga Brasileira Contra a Tuberculose, poucos meses depois da sua congênere paulista, buscou imitar a proposta fomentada por Clemente Ferreira, apresentando as mesmas vicissitudes e pouco fazendo em benefício dos infectados pobres do Rio de Janeiro e do resto do país, inclusive porque contava com verbas, instalações e equipamentos ainda mais precários que os disponíveis em São Paulo.

Nas demais cidades brasileiras, a situação sanitária referente à Peste Branca era ainda mais crítica. O levantamento realizado pelo Dr. Alfredo Britto, em 1929, mostra que mais da metade dos óbitos nacionais causados por doenças infecto-contagiosas era devido à tísica, sendo que raras eram as instituições dirigidas para o combate à fimatose que se encontravam em condições de prestar assistência aos pectários pobres (Britto, 1929).

Por isso, na década de 20 do século passado, ganharam maior intensidade as cobranças que visavam à participação dos poderes públicos no combate à Peste Branca, sendo raras as publicações e os congressos médicos nos quais não se reclamasse da ausência oficial na luta anti-tuberculose.

Até mesmo o higienista Afranio Peixoto, sempre comedido nas palavras de crítica ao Estado, incorporou-se no movimento. Ao avaliar a trajetória da saúde pública nacional, o médico não se absteve de elogiar o empenho do governo federal em sanear os grandes centros urbanos do país, mas, ao se deter no fato tuberculoso, Afranio Peixoto não se conteve, pronunciando uma enigmática sentença: "é alarmante e não move os que devem e podem...” (1923:88).

\section{O Estado Varguista e a Questão da Tuberculose}

Os anos 30 abriram-se sob uma crise econômica que resultou na ruptura da hegemonia oligárquica paulista e mineira no processo de tomada das decisões nacionais. A instalação de Getúlio Vargas no comando federal selou o encerramento de um período em que o Estado buscou amoldar-se à tradição liberal européia e aos princípios federalistas. Em continuidade, os ‘revolucionários' de 30 orientaram seus projetos no sentido da centralização dos canais decisórios e na ostensiva intervenção governamental no funcionamento da sociedade. 
A estratégia adotada por Vargas para reforçar a intervenção oficial nas instituições privadas e públicas correspondeu à expansão da burocracia governamental, inclusive na esfera da saúde coletiva. A multiplicação das instâncias oficiais e dos agentes do Estado favoreceu o desdobramento dos dispositivos legais e ordenadores da sociedade, alimentando a ilusão de que a administração pública era 'moderna' e 'racional', sendo, portanto, imune às contestações individuais ou de grupos.

A criação do Ministério da Educação e Saúde Pública, no mês de abril de 1931, inseriu-se na determinação do novo governo em redefinir a imagem que o Brasil desfrutava frente às potências internacionais. A presença de múltiplas epidemias e endemias que minavam a população impôs a organização de um instituto sanitário que tinha como principal objetivo revitalizar as formas de normatização e manutenção da capacidade produtiva do proletariado, em um período em que já não era mais possível contar com a reposição da força de trabalho mediante o aproveitamento de novos contingentes de imigrantes deslocados da Europa.

Acrescenta-se ainda que a ampliação da máquina administrativa da saúde abria oportunidades para o governo expandir seus pólos de vigilância sobre o tecido social, fato que se transformou em um dos principais recursos empregados por Vargas para a manipulação dos conflitos sociais.

Sob o lema de que a saúde se constituía em um dos ‘direitos básicos do cidadão brasileiro’, a Assembléia Nacional reunida em 1934 pontificou que cabia ao Estado zelar pelas condições sanitárias do país, intervindo nos momentos epidêmicos e sobretudo desenvolvendo ações educativas de prevenção às enfermidades.

Segundo o médico e parlamentar paulista Pacheco e Silva, era dever do governo desdobrar esforços para melhorar a “qualidade eugênica do Homem Brasileiro” (1934:5), mediante a proibição do ingresso no país de grupos de estrangeiros que se mostrassem perigosos para a Saúde Pública e também por meio de medidas que restringissem as taxas de morbidade e mortalidade que feriam a sociedade nacional, incluindo-se aí as baixas causadas pela Peste Branca.

Durante o governo Vargas, entretanto, as verbas federais destinadas à higiene coletiva foram sempre reduzidas e, pelo menos até 1938, aplicadas quase que exclusivamente na melhoria das condições sanitárias da capital da República. Com isso, esperava-se que cada um dos estados se responsabilizasse pela criação de fundos próprios para o atendimento dos enfermos pobres e para a prevenção das moléstias, fato que tornou ainda mais crítico o perfil epidemiológico da maioria das regiões brasileiras.

O resultado do afastamento do Estado dos compromissos que buscavam garantir a qualidade da saúde pública nacional pode ser notado inclusive na precariedade das ações oficiais contra a tuberculose. Durante os primeiros oito anos do governo varguista, o retrato mais invocado dos movimentos contra a Peste Branca foi aquele elaborado pelo professor Octavio de Freitas, ainda pouco antes da Revolução de 30: o acanhamento em número e a deficiência de funcionamento dos sanatórios e dispensários especializados, a falta de autoridade moral de quase todas as entidades estaduais contra a tísica e a ausência dos poderes públicos na luta sanitária.

No transcorrer da década de 30, o texto do Dr. Freitas (1929) foi continuamente invocado pelos médicos descontentes com a paralisia do setor sanitário governamen- 
tal, consagrando a denominação de 'Grande Mal' atribuída à moléstia que roubava as energias do povo e debilitava a capacidade produtiva nacional.

Em conseqüência, no ano de 1936, existiam poucas entidades direcionadas ao tratamento das vítimas do bacilo de Koch. O estado de São Paulo concentrava o maior número de unidades de saúde, contando com 14 sanatórios e hospitais-sanatórios, sendo seguido por Minas Gerais com três sanatórios, o estado do Rio de Janeiro com dois nosocômios e o Paraná com apenas uma casa de saúde especializada.

Todos os demais estados dispunham exclusivamente de alguns leitos hospitalares e de uns poucos ambulatórios mantidos pela iniciativa filantrópica. A escassez das vagas sanatoriais e o funcionamento irregular dessas instituições contrastavam com o número calculado de tuberculosos existentes naquele mesmo ano no país: cerca de meio milhão de infectados, segundo a Liga Paulista contra a Tuberculose.

Foi somente a partir de 1938 que a administração varguista mostrou-se disposta a elaborar um projeto federal de assistência aos doentes pobres, inclusive os tributários da tuberculose. Os motivos deste súbito interesse governamental em reforçar seus esquemas intervencionistas na saúde coletiva está certamente relacionado com o empenho varguista em normalizar o tecido social e também com a intenção de interferir na saúde popular como atitude preparatória para o lançamento da campanha oficial de ocupação de algumas áreas interioranas do país, fato que colocava a Saúde Pública como órgão encarregado de garantir migrantes saudáveis para o projeto governamental batizado como 'Marcha para o Oeste'.

Além disso, é necessário levar em consideração o fato de os Estados Unidos terem produzido, no decorrer da década de 30 do século passado, uma série de interpretações sobre a América Latina, anunciando a condição 'tradicional' dos países situados ao sul do mexicano rio Grande.

Em um desses relatórios, o higienista Charles Wilson (1942:11) concebeu a América Latina como uma verdadeira "sick man's society", cujo caráter avesso à modernidade era atestado pela multiplicidade das doenças infecto-contagiosas que assolavam as populações instaladas nesta porção do continente.

Para configurar ainda mais a condição desigual entre as sociedades de origem latina e anglo-saxônica, o médico colocou em confronto os perfis epidemiológicos das duas áreas, concluindo que, enquanto nos Estados Unidos a principal causa de óbitos era preenchida pelas moléstias degenerativas - em que destacavam-se os acidentes cardiovasculares -, a América Latina era vitimada principalmente por um conjunto de doenças contagiosas, sendo a tuberculose a patologia que mais cobrava vidas dos 'irmãos do sul'.

Almejando a condição moderna do país, Getúlio Vargas buscou emprestar novo rumo ao papel do Estado nas campanhas contra a doença pulmonar, mostrando-se sensível aos pedidos de apoio da até então apagada Federação Brasileira de Tuberculose entidade fundada em 1931 - e também oferecendo suporte econômico aos sucessivos Congressos Nacionais de Tuberculose, realizados a partir do final daquele decênio.

Mais ainda, o presidente encomendou ao diretor do Departamento Nacional de Saúde, o higienista João de Barros Barreto, a elaboração de um plano nacional e centralizador de combate à Peste Branca. Dois anos depois, em 1940, Barros Barreto 
finalizou o projeto requerido pelo presidente, ressaltando que a 'ameaça sanitária número um do país' deveria ser combatida por meio da criação de uma rede de sanatórios federais, localizados nas periferias das maiores cidades brasileiras.

Aprovado por Vargas, o documento preparado por Barros Barreto nunca chegou a ser colocado integralmente em prática, principalmente devido à perene alegação de escassez de verbas, fato que ditava o ritmo lento das edificações dos prédios que deveriam abrigar as casas de saúde especializadas. Por isso, muitos dos sanatórios idealizados no final dos anos 30 só foram entregues à comunidade uma década depois, momento em que a proposta médica de isolamento nosocomial dos tuberculosos entrava em franca decadência.

Situações como esta deixam claro que, apesar dos pronunciamentos oficiais que prometiam assistência aos doentes do peito, o Estado getulista hesitava em liberar verbas para o combate à Peste Branca e para o socorro das vítimas desta enfermidade. Tentando fugir ao compromisso de luta contra a disseminação da moléstia, ainda no ano de 1939, o presidente da República ordenou a formação de um comitê incumbido de corrigir o código previdenciário, atribuindo aos Institutos de Aposentadorias e Pensões a obrigação de prestar assistência médica e previdenciária aos trabalhadores consuntivos.

A comissão - constituída por médicos e administradores ligados à Sociedade Brasileira de Tuberculose e coordenada por Abelardo Marinho - buscou seguir de perto os posicionamentos contidos na Carta del Lavoro da Itália fascista, demandando o período de seis meses para apresentar o texto final de um anteprojeto que visava a instituir um seguro especial contra a tuberculose.

Mesmo afirmando desconhecer as 'condições próprias' da tísica no país, a equipe designada por Vargas advogou a criação de um órgão que denominar-se-ia Instituto de Tuberculose e Previdência Social, o qual seria financiado por um fundo originado da cobrança de um imposto a ser ativado em nome da ameaça infecciosa. Segundo esta proposta, cada trabalhador deveria contribuir mensalmente com no máximo um por cento de seu salário, sendo que os empregadores deveriam colaborar com quantia semelhante ao total pago pelos seus funcionários (Marinho, 1939).

Estabelecidos os fundamentos do amparo aos pectários, o governo reservava para si a missão fiscalizadora das tarefas realizadas pelo novo Instituto, delegando o gerenciamento do órgão a uma diretoria composta por representantes das Caixas de Aposentadorias e Pensões. Nesse contexto, marcado pela acirrada vigilância estatal, as ações atribuídas à instituição anti-tuberculosa compreenderiam o amparo financeiro e hospitalar aos trabalhadores infectados pelo bacilo de Koch, a constituição de uma rede nacional de sanatórios e também a organização e patrocínio de campanhas de esclarecimento público sobre a tuberculose.

O fato do anteprojeto situar a luta contra o Grande Mal como responsabilidade dos agentes previdenciários suscitou pronta reação das Caixas de Aposentadorias e Pensões. Isso porque a assistência aos tísicos de limitados recursos pecuniários mostrava-se como um negócio de pouco interesse, já que de escassa lucratividade, fazendo com que as Caixas alegassem 'falta de preparo' para administrar o Instituto de Tuberculose. 
Os setores previdenciários não pouparam esforços para atestar sua própria incapacidade financeira para o comando do problema fimatoso, alterando criminosamente os dados para 'provar' ao presidente Vargas que já estavam despendendo mais de 50\% de seus recursos anuais no pagamento de pensões e assistência médica aos operários tísicos (Métall, 1944).

Na série de medidas que visavam a impedir que o Estado colocasse o setor privado como responsável único pela solução das questões produzidas pela doença pulmonar, as Caixas uniram-se na elaboração de uma contraproposta ao plano governamental. Seguindo este intento, os nomes de Raphael Pardellas e Mario Pinto Passos ambos funcionários da Caixa de Aposentadoria e Pensões de Serviços Telefônicos do antigo Distrito Federal - ganharam conhecimento público como mentores das justificativas utilizadas pelas organizações previdenciárias que recusavam a direção dos trabalhos anti-tuberculose.

Segundo as perorações das Caixas, o Estado brasileiro já dispunha do arcabouço legal necessário para a prevenção e assistência aos tributários do Grande Mal, indicando-se o decreto número 16.300, datado do mês de dezembro de 1923, como instrumento jurídico que atribuía ao Departamento Nacional de Saúde Pública a responsabilidade de organização das ações sanitárias que objetivavam socorrer os fimatosos e limitar a disseminação da moléstia.

Para Pardellas e Passos, caberia à “laboriosa e moderna” administração estadonovista apenas "aparar algumas arestas" do antigo decreto para tornar "ainda mais eficaz” (Pardellas e Passos, 1941:276) o aparelhamento nacional de luta contra a tuberculose. Assim, por meio de uma retórica laudatória ao chefe da nação e ao mesmo tempo vazia de elementos esclarecedores, as Caixas buscavam devolver ao Estado a responsabilidade sobre o problema gerado pela Peste Branca.

Os mesmos analistas, ironicamente, centraram forças na depreciação dos serviços prestados pelas próprias Caixas para, por intermédio de uma cartada de risco, desestimular de vez a proposta oficial. Além de declarar que os diretores dos institutos providenciários não contavam com experiência suficiente para administrar uma organização tão complexa como seria o órgão de combate à tísica, os autores surpreenderam ao se posicionarem como denunciantes da precariedade do amparo prestado pelas Caixas aos contribuintes pectários, enfatizando a exigüidade do valor das pensões e também a baixa qualidade da assistência médico-sanatorial colocada à disposição dos trabalhadores adoentados.

Ainda em conformidade com o texto elaborado por Raphael Pardellas e Mario Passos, as verbas previdenciárias eram insuficientes para custear o tratamento do operário contaminado e garantir o sustento de seus dependentes.

A primeira opção oferecida pelos Institutos aos seus sócios tuberculosos correspondia a uma aposentadoria que raramente ultrapassava 50\% do valor do salário pago a um trabalhador não qualificado, quantia que mal dava para a alimentação de um indivíduo sadio, quanto mais para custear a existência de um tísico e de sua família. Nesse caso, alertava-se que, se o doente recebesse a pensão, a instituição previdenciária se eximiria da responsabilidade de oferecer tratamento gratuito ao consuntivo. 
A segunda opção era oferecida apenas aos portadores de lesões abertas e que necessitavam de intervenção cirúrgica imediata. Neste caso, a legislação em vigor garantia o direito à internação hospitalar por um período de até dez dias, podendo ser ampliada por um prazo mais extenso, dependendo da disponibilidade de verbas do órgão segurador, sendo que nesta situação o trabalhador não fazia jus ao recebimento da pensão. Por fim, a última alternativa era endereçada aos tuberculosos com lesões não abertas, os quais poderiam receber assistência especializada e 'algum auxílio pecuniário’, cujo valor variava segundo a entidade previdenciária à qual o enfermo estivesse ligado.

Após dedicarem-se às denuncias da fragilidade dos Institutos, os representantes das seguradoras ofereceram um substitutivo ao anteprojeto preparado sob a orientação de Abelardo Marinho. Para os dirigentes da máquina previdenciária, o documento getulista era plenamente viável, não obstante precisar de alguns reparos. O primeiro deles era inevitável: eximir as Caixas de qualquer compromisso nos esforços de combate à tísica, colocando em seu lugar o Estado. Em seguida, sugeria-se o aumento do seguro para $2 \%$ sobre o salário dos contribuintes e a alteração do nome da entidade a ser criada para Instituto de Seguro-Doença. Nada mais.

Em nome da proteção coletiva contra a moléstia de Koch, o confronto entre o Estado e as Caixas manteve-se vivo até o final do primeiro período presidencial de Getúlio Vargas, pouco resultando em benefício do proletariado. As raras leis federais e estaduais que focavam a obrigação social dos empresários com a saúde dos trabalhadores eram convenientemente 'esquecidas', deixando o operariado entregue à própria sorte.

Assim, mesmo que um decreto assinado ainda na República Velha exigisse que todas as fábricas que contassem com 'grande número' de empregados dispusessem de um dispensário especializado no atendimento dos doentes do peito, raramente isto aconteceu. No estado de São Paulo, apenas a Companhia Docas de Santos buscou cumprir esta disposição legal, mantendo um ambulatório para o tratamento dos seus funcionários contaminados.

A The São Paulo Tramway, Light \& Power Limited, considerada a mais moderna empresa no que tangia ao relacionamento entre capital e trabalho no período estudado também se dizia preocupada com o estado pulmonar de seus funcionários, tendo montado uma seção tisiológica. Entretanto, os relatórios assinados pelos médicos da empresa deixam notar que o principal objetivo do serviço clínico era impedir a admissão de operários infectados e não fazer o acompanhamento da saúde pulmonar dos funcionários que atuavam na companhia canadense.

Nesse encaminhamento, os trabalhadores não contavam com uma legislação que garantisse assistência médica e financeira digna àqueles que fossem vitimados pelo bacilo de Koch. Até mesmo o texto do decreto-lei no ${ }^{7.036}$, promulgado em novembro de 1944 e considerado 'avançado', inclusive pelos críticos da ditadura estadonovista, serviu-se de palavras vagas sobre a Peste Branca ao estabelecer as modalidades de amparo legal aos acidentados do trabalho.

A possibilidade de um eventual enquadramento da tísica como moléstia favorecida pelo processo produtivo estava distante dos interesses dos empregadores e, por óbvio, mantinha-se rigorosamente afastada dos documentos oficiais. Considerado como 
problema de difícil resolução no contexto da 'infortunística médico-legal', a tuberculose foi precariamente examinada pelos autores da lei e pelos advogados que estudaram a legislação varguista, limitando-se todos eles a anunciar a dificuldade de amparo legal aos trabalhadores que fossem infectados no ambiente da produção.

Os confrontos entre o Estado e os órgãos previdenciários resultaram em quase nenhum apoio aos infectados. Mesmo que todas as discussões alimentadas pela administração varguista tomassem o trabalhador formal como ponto de referência e alvo de uma possível política social, o tratamento dispensando aos tuberculosos pobres ocorria independentemente da modalidade de engajamento no processo produtivo. Excluído do amparo governamental, de regra, o tísico necessitado foi considerado 'indigente' e nesta condição buscava assistência e abrigo nos serviços médico-sanatoriais mantidos pela caridade pública.

\section{A Administração Tisio-sanitária em São Paulo}

Os sucessivos interventores indicados por Vargas para comandar a administração pública paulista, espelhando o direcionamento federal, assumiram a tutela da sociedade, fazendo a apologia de que o Estado constituía-se na única instância com legitimidade e capacidade suficientes para garantir a concretização dos interesses coletivos.

A influência federal no território bandeirante assentou-se na produção de uma copiosa legislação que pretendia garantir o controle das decisões tomadas nas múltiplas esferas da burocracia regional. A área da Higiene Pública foi, de imediato, um dos setores mais visados pela administração 'revolucionária', sobretudo porque a reforma sanitária realizada em 1925 conferiu autonomia ao sistema regional de saúde, instituindo os Centros de Saúde e os localizando como 'eixo central' do movimento preventivista e de tratamento dos enfermos no estado de São Paulo.

Um dos resultados da orientação assumida pelas autoridades paulistas impostas por Getúlio Vargas constituiu-se numa série de reformas que atingiram o Serviço Sanitário entre os anos de 1930 e 1931. Em conseqüência, o esquema higienista entrou em colapso, isolando o Instituto Butantan do organograma da Saúde Pública e, mais do que isto, reduzindo as atividades dos Centros de Saúde, que se transformaram em dispensários subordinados à Inspetoria de Higiene e Assistência à Infância.

A decisão oficial de ampliar o corpo de funcionários estaduais da saúde, sem contudo haver um planejamento adequado, frutificou em um verdadeiro caos, favorecendo a duplicidade de tarefas, a elevação dos custos dos serviços e, pior do que tudo isto, anulando as ações preventivistas em favor da medicina curativa.

A reorganização do aparelhamento sanitário bandeirante implicou inclusive na constituição de novos setores médicos e administrativos que deveriam responsabilizar-se, direta ou indiretamente, pela assistência aos fimatosos. Assim, ainda em fevereiro de 1931, foi criada a Seção de Profilaxia da Tuberculose, a qual deveria prestar atendimento dispensarial aos tísicos, realizando a tarefa que, antes do 'Golpe de 30', estava programada para ser implementada pelos Centros de Saúde. 
Mais ainda, a carência de pessoal especializado nos serviços exigidos pela tísica levou a Secretaria de Educação e Saúde Pública - criada no âmbito das reformas - a tornar oficiais os cursos oferecidos pelo Instituto de Higiene que tinham como meta a qualificação de técnicos de laboratório e de radiografia. No ano de 1932, o mesmo Instituto foi autorizado a instalar em suas dependências um gabinete de radiologia, abrindo oportunidade para que o paulistano obtivesse gratuitamente a Carteira de Saúde, documento instituído como elemento imprescindível para a colocação no mercado formal de trabalho, segundo uma lei sancionada no mês de abril daquele mesmo ano.

A proposta centralizadora da administração varguista resultou também na desapropriação do dispensário da Liga Paulista Contra a Tuberculose, mediante um processo legal que tramitou por três anos, encerrando-se a favor do Estado apenas em setembro de 1934. Acredita-se que este fato constituiu-se em mais um episódio da longa série de confrontos entre o médico Clemente Ferreira e as autoridades estaduais e federais.

Toleradas com certa benevolência no período anterior ao golpe de Vargas, as palavras ferreirianas sobre a ausência governamental no combate à Peste Branca foram entendidas como peças subversivas pelos interventores federais, desaguando no confisco do dispensário especializado e no afastamento do Dr. Ferreira do cargo de funcionário do Serviço Sanitário. Iniciou-se assim o declínio da influência e a marginalização do diretor da Liga Paulista Contra a Tuberculose, entidade que perdeu poder no mesmo passo que seu idealizador.

As tentativas reconciliatórias da administração pública com o diretor da Liga Paulista somente ocorreram alguns anos depois, quando o governador Armando de Salles Oliveira buscou homenagear o clínico, rebatizando o dispensário encampado com o nome de seu fundador, aproveitando a solenidade para indicar para a direção do órgão o médico Antonio Tisi Neto, amigo e principal discípulo do Dr. Ferreira. Na mesma oportunidade, o Serviço Sanitário alardeou que o centro de atendimento dos fimatosos seria transformado em um instituto de pesquisa da Peste Branca, função que, aliás, já vinha sendo desenvolvida pelo dispensário desde o início de suas atividades.

O alijamento do tisiologista Clemente Ferreira do comando das ações anti-tuberculose inscreveu-se no contexto centralizador, policialesco e pouco tolerante às críticas que ganhou dimensões maiores a partir da guerra paulista de 1932. Apesar disso, são constantes as vozes que tentam buscar outras explicações para a apropriação oficial do até então único dispensário filantrópico do estado de São Paulo.

Segundo esta vertente de entendimento, o confisco governamental deve ser creditado aos elevados custos exigidos pela assistência aos consuntivos, sendo o Estado a instância melhor capacitada para dispor de recursos de alta monta. Em coerência com este enunciado, tem-se apregoado que o Dr. Ferreira foi poupado - e não punido - pela administração pública que, solidária com as múltiplas atividades desempenhadas por este especialista, buscou liberá-lo da árdua tarefa de angariar os fundos necessários para o funcionamento do dispensário.

Excluído das discussões oficiais, mesmo assim Clemente Ferreira continuou a cobrar do Estado participação efetiva nas campanhas centradas na infecção pulmonar. No ano de 1935, durante uma solenidade em que compareceram inúmeras autoridades da administração pública, assim se pronunciou o tisiologista: 
As falhas e lacunas da nossa organização sanitaria contra o mórbo, a deficiencia ainda sensivel do nosso armamentarium antituberculoso, e a falta de uma coordenação metódica e de uma indispensavel articulação dos poucos aparelhos de que dispomos, explicam de sobejo porque não conseguimos ainda recúo sensível do nosso obituário pela grande endemia. (Ferreira, s.d.:276)

O resultado da escassa intervenção do Estado na questão tisiológica e da ineficiência dos profissionais de saúde agregados aos serviços estaduais pode ser constatado na curva ascendente produzida pelo número de óbitos causados pela tísica na cidade de São Paulo. Nesta metrópole, durante a primeira metade dos anos 30, a tuberculose alcançou índices bem superiores aos da década anterior, pois, se em 1923 a cidade apresentou uma taxa de 113,18 óbitos por consunção em cada 100.000 habitantes, dez anos depois este índice se elevou para 138,72, denunciando a velocidade alarmante com que a moléstia se disseminava pela urbe, fenômeno que se reproduzia em todas as regiões do estado (Grieco, 1939:9).

A explicação oficial para o avanço da Peste Branca, inevitavelmente, convergia para a exigüidade dos recursos públicos, numa conjuntura em que a crise econômica estava afetando todo o sistema capitalista. A urgência de se criar novos canais de captação de verbas para a saúde fez com que, desde janeiro de 1933, passasse a vigorar uma lei estadual que impunha taxação especial sobre a prática de jogos realizados em cassinos e clubes populares. Apesar disso, é de se perceber que o estado de São Paulo despendeu anêmicas verbas na luta contra a tísica, sendo que no período de 1932 a 1945, as despesas anuais com o Grande Mal variaram de 0,94\% a 2,05\% do montante de dinheiro destinado à Saúde Pública paulista.

Em conseqüência, as ações desenvolvidas pela Seção de Profilaxia da Tuberculose foram extremamente limitadas durante a maior parte da década de 30, ocupando poucas páginas nos relatórios administrativos oficiais. Em 1936, por exemplo, enquanto Clemente Ferreira calculava em 400 mil o número de fimatosos existentes no país, sendo 54 mil deles só no estado de São Paulo, os dados fornecidos pelo governo do Estado informam que a ação pública resumia-se ao gerenciamento do Instituto Clemente Ferreira e de um dispensário inaugurado no distrito do Brás, o qual pouco depois teve suas atividades encerradas por 'absoluta falta de funcionários'.

Mesmo assim, durante aquele ano, cerca de dez mil indivíduos procuraram espontaneamente os serviços públicos de tisiologia, ocorrendo a identificação de aproximadamente mil novos casos de tuberculose, sendo que nem todos puderam seguir tratamento devido à escassez de profissionais especializados nessas unidades de saúde. As ações preventivas com base na aplicação da vacina BCG também se mostraram precárias, sendo inoculados apenas 1.432 crianças e adolescentes, fato que elevou para 5.301 o número de indivíduos imunizados no estado de São Paulo, desde o ano de 1929, quando começou a funcionar o Serviço regional de vacinação.

O frágil empenho oficial em intervir com eficácia na questão sanitária determinou que as iniciativas privada e filantrópica ocupassem a função primordial de tratamento e assistência material aos consuntivos e seus dependentes. Como resultado, a década de 30 testemunhou a constituição de uma rede de sanatórios que, concentrada na cidade de São Paulo e nas prefeituras sanitárias de Campos do Jordão e São José dos Campos, 
encontrava sustento nas mensalidades cobradas aos pacientes e nos donativos promovidos pela caridade pública.

Segundo o tisiologista Paula Souza (1939:330), no final daquele decênio existiam no estado de São Paulo “menos de 2 mil” leitos reservados para os consuntivos, sendo que uma parte das vagas estava desativada, pois as doações oferecidas pela sociedade eram reduzidas e o "tuberculoso custa caro".

O único apoio dado pela administração pública aos sanatórios paulistas constituiu-se em irregulares dotações orçamentarias, sob o compromisso das casas de saúde beneficiadas acolherem gratuitamente alguns pectários encaminhados pelo Serviço Sanitário, ou ainda para que os sanatórios expandissem o número de seus leitos.

Os dados oferecidos em 1936 pela Comissão de Assistência Hospitalar da Secretaria da Educação e Saúde Pública informam que as verbas oficiais destinadas aos nosocômios especializados foram da ordem de 1.790:471\$312, sendo que a Irmandade da Santa Casa de Misericórdia paulistana foi a instituição mais beneficiada, recebendo cerca de um quarto do total das doações para promover melhorias nos prédios dos dois sanatórios que estavam sob seu gerenciamento.

O rumo da administração paulistana em relação ao Grande Mal sofreu sensível correção a partir de 1938, refletindo a mudança que se processou em nível federal no que dizia respeito ao 'inimigo número um da saúde pública nacional'. Nesse mesmo ano, o médico Adhemar de Barros foi nomeado interventor federal em São Paulo, dando início a mais uma alteração na organização e nas estratégias diretoras do aparelhamento sanitário regional.

A nova reforma geral dos serviços de Higiene Pública foi inaugurada com o decreto 9.247, de junho de 1938, por meio do qual foi criado o Departamento Estadual de Saúde, sendo definitivamente extinto o Serviço Sanitário. Os motivos alegados para a remodelação do setor foram vários, sendo o principal deles o argumento de que as sucessivas alterações ocorridas na estrutura administrativa da saúde coletiva haviam transformado o órgão em um setor ineficiente e que se mostrava inoperante, enquanto inúmeras enfermidades de caráter infecto-contagioso expandiam seus domínios no estado de São Paulo.

A orientação adhemarista restabeleceu o funcionamento dos Centros de Saúde como unidades basilares dos serviços de Higiene Pública. Concomitantemente a esta decisão, a voz oficial assumiu o retrocesso causado pelo conjunto de reformas realizadas nos primeiros anos do período varguista, confidenciando que a extinção dos Centros de Saúde, no início da década de 30 do século passado, deveu-se sobretudo às pressões de ‘muitos clínicos' que denunciaram tais núcleos de atendimento aos enfermos como desleais concorrentes dos consultórios privados.

Superado o conflito, um decreto datado do mês de junho de 1938 determinou a imediata reativação de uma dezena de Centros de Saúde nos distritos da Capital e a transformação das Delegacias de Saúde e dos Postos de Higiene interioranos em 'unidades sanitárias ecléticas e polivalentes’. Tudo isto, segundo o Dr. Raul Godinho, diretor do Departamento Estadual de Saúde, para permitir que o Brasil definitivamente deixasse de ser 'um vasto hospital'. 
Como órgão orientado, inclusive para assistência aos doentes do peito, os Centros de Saúde contavam obrigatoriamente com horários de atendimento exclusivo aos tuberculosos e também com um corpo de visitadoras sanitárias que, dentre as suas funções, deveriam percorrer as residências situadas nas áreas consideradas de maior incidência da tísica, com a missão de localizar e encaminhar para tratamento os possíveis casos de infecção consuntiva, além de ensinar à população os cuidados preventivos contra a contaminação pelo bacilo de Koch. Nesse sentido, os Centros de Saúde foram definidos como 'porta de entrada' dos fimatosos para o sistema especializado de saúde, cabendo a estas unidades a decisão sobre a necessidade ou não de isolamento sanatorial dos tísicos.

Ainda em conformidade com a remodelação de 1938, o Departamento de Saúde manteve no organograma a Seção de Profilaxia da Tuberculose, estabelecendo como seu objetivo básico a garantia de funcionamento do Instituto Clemente Ferreira. Entretanto, no mesmo ano, o relatório elaborado pelo Dr. Marques Simões, diretor da Seção, deixou claro as péssimas condições em que se encontrava o antigo dispensário da Liga Paulista: número insuficiente de servidores, salários inferiores aos que eram pagos em outras repartições sanitárias, desorganização burocrática, inexistência de móveis e arquivos e escassez de material imprescindível para a realização de pesquisas e para o tratamento dos infectados que recorriam ao Instituto.

Apesar da precariedade comprometedora dos serviços de socorro aos tributários da Peste Branca, em fins do mesmo ano de 1938 foi inaugurado o Hospital-Sanatório do Mandaqui, o primeiro nosocômio construído e mantido pelas verbas estaduais e direcionado exclusivamente para o atendimento de pacientes consuntivos. Localizado na zona norte paulistana, a casa de saúde foi aberta com a presença de Getúlio Vargas e Adhemar de Barros, constituindo-se em cerimônia que marcou o início da efetiva participação oficial no movimento de edificação de sanatórios voltados para o isolamento sanitário do proletariado e das camadas médias.

O prestígio alcançado por Adhemar de Barros e por sua esposa Leonor Mendes de Barros em conseqüência do empenho de ambos em participar do movimento contra a Peste Branca mostrou que o assistencialismo orientado para os tuberculosos poderia fornecer ao interventor o apoio popular necessário para as futuras disputas políticas. Por isso, mais do que em qualquer outro estado, em São Paulo frutificou uma série de promessas que anunciavam a rápida criação de um grande número de sanatórios financiados pelas verbas paulistas, apesar da constância de menções ao compromisso do presidente da República em co-patrocinar os projetos nosocomiais.

No relatório elaborado pelo Serviço de Assistência Hospitalar de São Paulo referente ao ano de 1938, encontram-se registrados os planos de criação de cinco novos sanatórios públicos, o que representava o acréscimo de mais de mil leitos à disposição dos consuntivos. É significativo que todos já tinham recebido denominações apropriadas para o tempo: três deles receberam o nome de Adhemar de Barros, enquanto cada um dos demais foi batizado com o nome do presidente da República e da primeira-dama do estado de São Paulo.

Enquanto as promessas da construção de novos sanatórios se reproduziam com uma velocidade singular, na verdade, ainda dispunha-se de poucos leitos destinados para 
os tuberculosos que viviam no estado de São Paulo. Segundo o relatório referente ao ano de 1938, existiam na área paulista apenas 1.412 leitos destinados aos tuberculosos, representados pelo funcionamento de sanatórios e abrigos situados nos municípios de São Paulo, Campos do Jordão, São José dos Campos e Tremembé e ainda pelos pavilhões especializados das Santas Casas de Santos, Campinas, Bragança Paulista e Sorocaba.

Os administradores públicos, em todo o território nacional, haviam se mantido excessivamente afastados do desafio tuberculoso. Assumida como grave ameaça para a saúde coletiva no início do período republicano, a Peste Branca e seus possíveis tributários só foram objetos de intervenção oficial nos últimos anos da década de 30 do século passado, quando o Brasil já se definia como um dos principais centros de tuberculosos do continente americano.

As tímidas tarefas desempenhadas pelos órgãos sanitários, no decênio anterior ao advento da estreptomicina, certamente influenciaram o ritmo de disseminação da moléstia pulmonar, sem, no entanto, inverter a tendência ascendente dos índices referentes à maior parte dos estados brasileiros.

Um estudo comparativo dos óbitos atribuídos à tuberculose nos anos de 1936 e 1945 indicam que, das 19 capitais estaduais averiguadas, 12 mantiveram-se em estado de 'epidemia plena' com índices crescentes, inclusive as cidades de Belo Horizonte, Recife, Salvador e Porto Alegre, enquanto a capital paulista e o Distrito Federal apresentavam taxas praticamente semelhantes nos dois períodos (Borges, 1948).

As evidencias sobre os estragos causados pela Peste Branca na população multiplicavam-se. Quando, no ano de 1943, “mais de 100.000” homens oriundos de todas as partes do país foram chamados pelo Exército para compor a Força Expedicionária Brasileira, entre 50\% e 80\% dos convocados de cada região militar foram declarados "incapazes definitivamente" para prestar o serviço militar, pelo fato de apresentarem uma ou mais patologias que comprometiam o desempenho físico dos recrutas. Nesse contexto, a tísica se apresentava como moléstia reinante - mas nunca publicamente quantificada - das baixas antecipadas (Gonçalves, 1951).

A recusa por parte do Estado e das Caixas em conceder assistência médica e previdenciária integral aos trabalhadores tuberculosos era fato consumado, colocando-se como tendência ininterrupta na primeira metade deste século. A decisão políticoadministrativa de tratar a legião de trabalhadores infectados como problema de difícil solução guardava íntima coerência com a diversidade de posicionamentos que instruíam os debates entre tisiologistas. Isso porque, refletindo as dificuldades sociais de entendimento da tuberculose e de suas vítimas, o agrupamento médico especializado mostrava-se crivado de dúvidas sobre como tratar os consuntivos e prevenir o avanço da enfermidade no terreno coletivo.

\section{NOTAS}

1 Optamos por manter a grafia original dos textos e documentos citados. 



\section{4}

\section{As (In)Certezas da Medicina}

O enquadramento institucional das questões suscitadas pelo Grande Mal afetou diretamente a comunidade médica nacional que, ao mesmo tempo em que buscava expandir o leque de privilégios que lhe era concedido por Vargas, também compunha forças para garantir relativa autonomia em relação às contínuas intervenções dos setores oficiais.

A década de 30, neste sentido, contextualizou o nascimento e a consolidação de várias entidades representativas dos profissionais da saúde, destacando-se a carioca Federação Brasileira de Tuberculose e, em São Paulo, o início de funcionamento da Associação Paulista de Medicina e da Associação Paulista de Homeopatia, além de outras congregações de clínicos que, atuando em nível regional, expressavam as diversas especialidades hipocráticas.

Os tisiologistas que praticavam no terreno bandeirante mantiveram-se avessos à organização de um órgão representativo próprio, cedendo à proposta agremiativa somente em novembro de 1949, quando foi criada a Sociedade Paulista de Tisiologia. O prestígio acumulado por esses especialistas, entretanto, ensejou que desde o início da década de 30 fosse reconhecida a existência de uma comunidade que foi usualmente definida como 'escola paulista de tisiologia', considerada por vários pesquisadores como a mais eficiente equipe de clínicos e cirurgiões voltada para as tarefas de prevenção e de tratamento da tuberculose, em todo o país.

Apesar de a maioria das unidades sanatoriais do estado localizarem-se nos municípios de Campos do Jordão e São José dos Campos, era na cidade de São Paulo que se situavam os dois principais núcleos paulistas de ensino, pesquisa e tratamento cirúrgico dos consuntivos, sendo o Instituto Clemente Ferreira e o Hospital-Sanatório São Luiz Gonzaga os postos fomentadores das mais importantes ações estaduais contra a Peste Branca.

Se as atividades do Instituto fundado pelo Dr. Ferreira encontravam-se em franca decadência desde o instante em que a entidade fora estatizada, o mesmo não se pode falar do Hospital-Sanatório São Luiz Gonzaga que, desempenhando as funções de sanatório de isolamento e de nosocômio especializado no tratamento dos pectários, concretizou-se como instituto pioneiro no contexto médico nacional. Inaugurado nos primeiros dias da chamada 'Revolução de 32' e mantido pela Irmandade de Misericórdia da Santa Casa de São Paulo, o Hospital do Jaçanã - como ficou também conhecida esta 
casa de saúde - localizava-se no limite norte do município, ocupando as antigas instalações do Leprosário do Guapira.

A condição de este sanatório estar filiado administrativamente à Santa Casa e também atuar como campo de ensino permitiu que o hospital especializado contasse com um quadro clínico altamente qualificado, atraindo médicos de todo o país, unidos pelo interesse de treinamento na área tisiológica. Como um dos principais centros de referência nacional para o tratamento da Peste Branca, o Sanatório do Jaçanã formou uma elite de especialistas que iria ocupar posições dirigentes não só nas casas de saúde voltadas para o atendimento dos fimatosos, mas também nos novos postos de tratamento dos pectários que foram instalados em São Paulo, inclusive no Hospital-Sanatório do Mandaquí e no setor de doenças pulmonares da Escola Paulista de Medicina.

Nesse contexto, foi-se firmando o espírito corporativo que colocou em contato os tisiologistas do estado de São Paulo e de todo o Brasil. A consolidação do ensino médico sobre a tuberculose em São Paulo e no Rio de Janeiro permitiu que se tornasse regra a cobrança do diploma de especialista a todo clínico que se propusesse a assistir doentes do peito. Caso tal documento não fosse apresentado, o facultativo 'infrator' era denunciado como intruso que, no mais das vezes, relegava a segundo plano o compromisso de assistência aos infectados pelo bacilo de Koch, em favor dos ganhos pecuniários resultantes do atendimento aos pacientes consuntivos.

A determinação exclusivista passou a alimentar os discursos da corporação dos tisiólogos. As acusações movidas contra os clínicos gerais, especialmente os atuantes nos ambientes interioranos, tornaram-se corriqueiras, havendo denúncias que tais esculápios omitiam o estado contaminado de seus pacientes endinheirados para assim lucrarem com o alongamento da série de consultas realizadas pelo enfermo.

Na seqüência, os especialistas foram a público por meio de artigos estampados na Revista Paulista de Tisiologia e na Revista Brasileira de Tuberculose para alertar a sociedade sobre a precariedade dos conhecimentos de seus colegas não iniciados nos segredos da tísica, apresentando-os como tão despreparados para o diagnóstico e tratamento da doença pulmonar que muitos deles nem mesmo sabiam distinguir um aparelho de Raio X de outros instrumentos utilizados pela medicina.

\section{Harmonia e Conflito: a construção da especialidade médica}

A consolidação do prestígio das novas equipes tisiológicas que foram montadas em São Paulo e no Rio de Janeiro refletiu na avaliação do desempenho do professor Clemente Ferreira e de outros médicos que comandaram a luta contra a Peste Branca nas três décadas anteriores a 1930.

Reverenciado como um dos principais mentores da medicina pulmonar brasileira, o diretor da Liga Paulista Contra a Tuberculose passou a ser tachado - não sem uma certa dose de ironia - como um ‘médico antigo' e defasado, uma espécie de filantropo que distribuía remédios, roupas e dinheiro aos seus pacientes, mas que se distanciara das modernas técnicas de combate à moléstia consuntiva. 
Em resposta às críticas das quais vinha sendo alvo e também à marginalização oficial de sua pessoa, Clemente Ferreira buscou exponenciar a importância de seu trabalho por meio da composição de minuciosos relatórios anuais sobre os trabalhos desenvolvidos pela Liga que dirigia e também mediante a fundação da Revista Paulista de Tisiologia, publicação bimestral que começou a circular no mês de janeiro de 1935. Para sustentar o empreendimento editorial, o Dr. Ferreira contou com o auxílio de seus mais diletos discípulos, encontrando recursos econômicos para a impressão e distribuição do periódico na abertura da coleção para anúncios de laboratórios e casas de saúde que vendiam produtos e serviços ligados ao Grande Mal. ${ }^{1}$

Criado com o intuito de divulgar as pesquisas realizadas no estado de São Paulo, o periódico ferreiriano tinha como objetivo secundário servir como veículo da desaprovação dos facultativos paulistas sobre a política de saúde centralizadora de Getúlio Vargas, que os havia excluído do centro decisório da administração sanitária nacional e, em alguns níveis, do comando da Saúde Pública estadual.

Apesar de ter nascido no Rio de Janeiro, Clemente Ferreira havia adotado a terra paulista, fazendo estampar a bandeira estadual na capa de vários números da sua Revista. Sob este direcionamento, a publicação especializada buscou dar destaque aos tisiologistas de São Paulo como autores das principais tentativas formuladoras do pensamento tisiológico nacional e, por contraste, os higienistas radicados no Distrito Federal como os responsáveis pelas estéreis reorganizações sanitárias que se sucederam no decorrer dos anos 30.

Nesta rota, a Revista Paulista de Tisiologia ocupou a posição de porta-voz privilegiada dos interesses e dos dilemas que pontuavam as ações dos profissionais dedicados à luta contra a Peste Branca, anunciando as tendências de congraçamento e os confrontos que davam vida aos debates corporativos.

\section{as Tentativas Congregadoras}

Desde os primeiros números da Revista, encontram-se artigos assinados pelo grupo ferreiriano, cujo teor básico constitui-se nos reclamos contra a inoperância governamental em relação à Peste Branca e também nas denúncias sobre o isolamento do alto escalão da administração sanitária estadual em relação à maioria dos médicos que atuavam no setor.

Tornou-se corriqueira a publicação especializada divulgar textos como os subscritos por médicos que, embora ocupassem postos no Serviço Sanitário paulista, faziam do periódico um canal de comunicação com os seus superiores da administração pública, oferecendo sugestões e reparos às ações que o Estado vinha realizando - ou deixando de realizar - na assistência aos tuberculosos. E isso tudo como se os articulistas fossem pessoas estranhas ao setor higienista oficial.

Paralelamente à publicação das declarações críticas assinadas pelos facultativos, a tentativa mais significativa da Revista para congregar os tisiologistas de São Paulo constituiu-se na realização, no decorrer do primeiro semestre de 1935, de um 
amplo inquérito que deveria servir de base para a elaboração de uma proposta paulista a um possível plano federal contra a tuberculose.

Questionário destinado a ser respondido por todos os especialistas na Peste Branca que atuavam no estado, de tudo perguntava-se aos clínicos, desde a origem dos recursos que subsidiariam o plano, até a localização geográfica ideal dos sanatórios a serem construídos, o critério de triagem dos fimatosos encaminhados para internamento, os hospitais que deveriam se encarregar das tarefas tisiocirúrgicas e os canais de treinamento especializado dos profissionais da saúde.

O primeiro médico a responder ao questionário foi Raphael de Paula Souza, que entre outras funções ocupava o cargo docente no Instituto de Higiene da Universidade de São Paulo. Segundo este clínico, todas as campanhas contra a enfermidade de Koch deveriam ser patrocinadas pelos cofres públicos, mas o gerenciamento das ações sanitárias ficaria obrigatoriamente a cargo de médicos não comprometidos com os grupos que se engalfinhavam na arena política. Mais ainda: o Dr. Paula Souza declarou que, no contexto regional, inexistia uma entidade formalmente direcionada para aprimorar o conhecimento sobre os mecanismos da fimatose, situação que delegava aos sanatórios a tarefa de formação e atualização do agrupamento tisiológico.

Na seqüência, inúmeros facultativos atenderam ao inquérito, e algumas das respostas foram reproduzidas nas páginas do periódico dirigido por Clemente Ferreira. O empenho da Revista em expor o descontentamento dos médicos em relação ao Estado varguista frutificou, mas também permitiu que clareassem os antagonismos doutrinários e os interesses institucionais divergentes que impregnavam os debates sobre a Peste Branca.

Assim, tem-se como exemplo as sucessivas discussões em torno da prática de cirurgias torácicas. Para alguns médicos, não só os sanatórios instalados nas estações de cura de Campos do Jordão e de São José dos Campos - áreas que foram definidas administrativamente como 'prefeituras sanitárias' -, como também os Postos de Higiene espalhados pelo estado estavam plenamente capacitados para proceder às intervenções cirúrgicas mais simples.

Lançado o argumento, vários integrantes da equipe médica que atuava no Hospital São Luiz Gonzaga postaram-se energicamente contra a proposta, alegando que a precariedade das enfermarias sanatoriais e o despreparo dos profissionais alocados na maior parte dos Postos de Saúde desaconselhavam que as operações fossem realizadas em outro ambiente que não o próprio Sanatório do Jaçanã.

A tentativa de articulação de um projeto paulista único e de autoria dos especialistas na Peste Branca mostrava-se cada vez mais difícil. Para além dos interesses institucionais, outros clínicos aproveitaram a oportunidade aberta pelo inquérito para expor idéias que, pelo momento político, certamente suscitavam constrangimento e receio entre o agrupamento médico de São Paulo.

Nesta direção, o Dr. Ivan de Souza Lopes, clínico de Campos do Jordão, respondeu ao questionário de maneira incisiva e única, criticando tanto os políticos que interferiam no planejamento sanitário quanto os docentes da Faculdade de Medicina da Universidade de São Paulo que, segundo este tisiologista, ofereciam um ensino de péssima qualidade aos seus alunos. O que mais importunou os leitores da Revista, 
porém, foi a manifestação desqualificadora do saber médico como o principal instrumento para conter a disseminação do Grande Mal. Lembrando as críticas anarquistas elaboradas nas décadas anteriores, foi com estas palavras de alerta que o Dr. Souza Lopes definiu as condicionantes básicas do alastramento da tísica no corpo coletivo:

O problema da tuberculose é, antes de ser um problema médico, um problema social. Querer resolve-lo por meio de instituições ou de organizações é procurar desconhecer voluntariamente a verdadeira realidade. Essas instituições só poderão fazer 'prophylaxia directa', quando a questão é essencialmente de 'profilaxia indirecta', isto é, de combate à miseria, à falta de conforto, à subalimentação, ao trabalho excessivo. Não se póde, na lucta contra a tuberculose, esquecer, logo, o aspecto fundamental da questão, numa cumplicidade flagrante com as causas principaes do flagello. A unica lucta consequente seria, sem duvida alguma a lucta pela elevação do nivel economico e cultural das populações brasileiras. (1935:299)

Entre a velha "prophylaxia directa" e a nova "profilaxia indirecta" existia um abismo desafiador dos cômodos esquemas explicadores da problemática sanitária nacional. Os temores de uma medicina sempre cautelosa em assumir a 'causação' social e coletiva das enfermidades somavam-se aos dispositivos repressores que vigiam no período getulista, impondo que nenhuma resposta fosse endereçada ao libelo assinado pelo Dr. Souza Lopes. Perpetuava-se, assim, a definição epidemiológica da Peste Branca como 'moléstia social'pelo fato desta patologia estar disseminada amplamente na trama coletiva, nada mais do que isso.

Sintomaticamente, desde a veiculação das idéias do clínico de Campos do Jordão, a série dirigida por Clemente Ferreira não mais se reportou ao inquérito, como se jamais ele tivesse existido. Como muitas outras tentativas corporativas dos anos 30 , a proposta de elaboração de um projeto sanitário paralelo ao assumido pelo Estado esvaiu-se em um silêncio intimidado, legando aos médicos escritores como Amando Fontes e Ranulpho Prata a tarefa de apresentar a tísica, por meio da fiç̧ão, como mortal resultado das desigualdades sociais que marcavam a sociedade brasileira.

O compromisso grupal que regia os primeiros momentos da publicação especializada teve seus rumos corrigidos quando a Revista Paulista de Tisiologia convenceu-se de que o Estado getulista não se afinava com os pronunciamentos de crítica à postura governamental. Mesmo que se mantivesse acesa a explicação que situava a fimatose como flagelo que 'aniquilava a raça', 'devastava a população' e, em continuidade, 'desfalcava o capital humano e empobrecia o país', as declarações médicas fugiram das especulações que apontavam a moléstia pulmonar como produto dos desregulamentos da sociedade, fazendo predominar os estudos centrados na organização das campanhas contra a tuberculose, nas técnicas terapêuticas e nos assuntos corporativos.

Em decorrência, um dos novos temas utilizados na tentativa de mobilização da categoria tinha base nos ecos provenientes do estrangeiro. Da França chegavam notícias que asseveravam a desnecessidade do asilamento sanatorial no tratamento dos pacientes consuntivos. 
Contra tal proposta insurgiram-se os clínicos que atuavam nos sanatórios paulistas, especialmente o Dr. Manuel Corvello Junior que, na condição de tisiologista assistente de duas casas de saúde de renome, considerou a idéia absurda. Espelhando o posicionamento que não era aceito por todos os seus pares, este clínico desqualificou a possível eficiência do tratamento domiciliar dos infectados, alegando que os detratores do regime de isolamento hospitalar eram pessoas "má intencionadas" (Corvello Junior, 1936:96) que, indo contra os ensinamentos dos "grandes mestres", ocultavam interesses escusos que o médico não soube esclarecer quais eram.

As dificuldades encontradas para consolidar os vínculos comunais exigiam que, periodicamente, fossem lembrados os riscos de infecção inerentes à prática tisiológica. É digno de nota o empenho do Dr. Xavier do Prado para sensibilizar os 'bons corações' em prol da construção de um sanatório exclusivo para o tratamento dos facultativos contaminados. A urgência de socorro aos 'companheiros consuntivos' foi explicada por meio de palavras tão francas quanto dolorosas: "seja elle medico ou não, o tuberculoso é sempre despresado, para muitos até um indesejavel” (Prado, 1936:154).

Até mesmo a campanha liderada pelo Dr. Xavier acabou submergindo no desencontro de idéias entre os membros da corporação. Instalado o debate, a comunidade clínica dividiu-se sobre o local apropriado para a instalação da casa de saúde dos facultativos, uns apoiando a construção do sanatório nas montanhas jordanenses, enquanto outros preferiam a periferia paulistana. Como em outros momentos, o conflito resultou em seguidos desentendimentos que acabaram tornando impraticável a proposta assistencial.

Neste emaranhado de confrontos, foram raras as questões que garantiram uma certa harmonia entre os tisiólogos. A primeira delas constituiu-se no interesse grupal para exponenciar a lucratividade da profissão de médico dos tuberculosos. Em um país onde havia escassez de leitos mesmo para os infectados que contavam com recursos econômicos, tornou-se freqüente os movimentos que visavam à organização de empresas que, compostas exclusivamente por facultativos, tinham como objetivo a construção e o funcionamento de sanatórios particulares.

No ano de 1941, por exemplo, ganhou destaque na imprensa médica a movimentação em torno da venda dos últimos lotes de ações do Hospital Santo Antônio S.A., um sofisticado nosocômio para tísicos que estava sendo construído na zona norte do município de São Paulo, em terreno próximo ao do Sanatório do Mandaquí. Anunciado nas páginas da Revista da especialidade como um "excepcional negócio”, os compradores das ações teriam obrigatoriamente de apresentar o diploma de graduação em medicina, exigência que alinhou como sócios mais de uma centena de clínicos, encabeçados por quatro professores titulares da Faculdade de Medicina da Universidade de São Paulo: Celestino Bourroul, Eduardo Monteiro, Rubião Meira e Raphael Penteado de Barros. No final do documento, os dirigentes do negócio anunciaram aos seus pares acadêmicos a alta lucratividade da empresa exploradora da tuberculose: "Por ser um negócio rigorosamente de médicos, deve merecer o seu apoio. Apresenta-se como ótima oportunidade para nele o Snr. inverter, muito vantajosamente, algumas economias, cuja multiplicação ser insofismável”. 
Outro assunto que favorece uma comunhão entre os médicos adestrados na doença pulmonar configurou-se na apologia grupal do processo de roentgenfotografia, aperfeiçoado no ano de 1936 pelo clínico carioca Manoel de Abreu e que foi imediatamente rebatizado pelos especialistas com o nome de 'abreugrafia'. Consistindo em recurso mais rápido, econômico e eficiente para, por meio do Raio X, revelar as lesões tuberculosas ainda nos estágios iniciais, a "fotografia do écran fluorescente" foi assumida como contribuição genuinamente nacional para o controle da Peste Branca, sendo objeto de louvor por toda a medicina brasileira.

Quebrando a regra desmerecedora do que era produzido pelos tisiologistas cariocas, os médicos de São Paulo mostraram-se sensíveis à campanha liderada pelo próprio Manoel de Abreu, que propunha a realização de um recenseamento torácico em escala nacional. Em nome da proteção da saúde coletiva, o cientista requereu ao presidente Vargas a aprovação de leis que obrigassem toda a população a se deixar examinar dos pulmões, compromisso que permitiria a organização de um cadastro social onde o Estado saberia quem e quantos eram os consuntivos residentes no país.

Amparado no sucesso de seu invento, coube também ao professor Abreu a criação de um novo personagem disseminador do bacilo de Koch: o 'aparentemente sadio'. A partir de então, não eram só os tipos abatidos, descarnados e 'promíscuos' que chamavam a atenção dos sanitaristas, mas também os indivíduos gordos e que apresentavam boa disposição física. Tanto uns quanto outros poderiam ocultar em seus corpos o micróbio causador da corrupção pulmonar, sendo por isso conveniente a averiguação do estado pulmonar de todos os cidadãos (Abreu, 1938:1943).

Imediatamente após a divulgação da proposta do inventor da abreugrafia, os médicos paulistas somaram-se nos pedidos ao governo estadual para que os cofres públicos financiassem a aquisição de várias unidades do 'aparelho revolucionário'. Segundo um dos requerentes, o novo engenho permitiria o diagnóstico precoce da infecção, protegendo a sociedade de seus perigosos membros contaminados:

O exame sistematico pulmonar das coletividades foi ensaiado primeiro nos exércitos e nas armadas de diferentes paízes europeus e americanos. Os resultados foram os mais interessantes, e grandes as supresas! Individuos de ótimo físico, aviadores, esportistas (...) apresentavam graves lesões tuberculosas pulmonares à radiografia. (Franco, 1937:77)

Apesar da veemência dos pedidos, foi apenas em meados de 1938 que o Departamento de Saúde paulista recebeu o aparelho de abreugrafia que, inexplicavelmente, foi utilizado em raras ocasiões por aquele órgão oficial. Isso porque logo que foi incorporado ao acervo estadual, a 'máquina de Abreu' foi emprestada à Universidade de São Paulo para a realização do exame pulmonar dos alunos ingressantes naquela instituição de ensino. Na seqüência, o governo cedeu o aparelho para o Instituto dos Bancários que, até o final da década de 40 , foi a única entidade previdenciária a realizar o recenseamento torácico de todos os seus associados.

O restrito uso do dispositivo desenvolvido pelo Dr. Abreu, entretanto, não inibiu os líderes da tisiologia de São Paulo a se convencerem da necessidade da contínua vigilância dos 'pretensos sadios’. Na ausência do recurso desenvolvido pelo clíni- 
co carioca, os higienistas se convergiram para a realização de pesquisas na comunidade por meio do emprego da tuberculina como estratégia identificadora dos grupos que apresentavam a ‘tuberculose-infecção' e - quem sabe? - a moléstia propriamente dita.

Como resultado, se o período anterior à incorporação da figura do 'tísico inaparente’ como tema epidemiológico testemunhou apenas três avaliações coletivas, a partir de 1936 e até 1945 foram realizados pelo menos vinte recenseamentos deste tipo. A comunidade estudantil foi o estrato mais visado da população estadual, instruindo onze inquéritos com base no exame dos alunos matriculados nas escolas de educação elementar e também duas pesquisas centradas nos estudantes dos primeiros anos dos cursos oferecidos pela Universidade de São Paulo.

\section{Os Conflitos Doutrinários}

O fato de o Brasil apresentar-se como um país de acanhada tradição no desenvolvimento científico impôs que os Hipócrates nacionais, com exceção de Manoel de Abreu, pouco contribuíssem com novidades para o esclarecimento da moléstia pulmonar, fazendo moeda corrente as monótonas repetições das idéias esboçadas no estrangeiro. Neste contexto, as disputas acadêmicas forçavam a contínua publicação de textos que, de regra, reproduziam as análises da tisiologia européia, chegando ao ponto de alguns esculápios nativos não se furtarem de enveredar pelos sombrios becos do plágio.

A precariedade geral de recursos e mesmo de conhecimentos aprofundados sobre o Grande Mal induziram os facultativos a advogarem uma série de procedimentos que, por serem demasiadamente desatualizados ou simplistas, selavam a imagem de uma medicina periférica e sempre defasada em relação às concepções em voga na Europa.

Assim, no período em que os especialistas do Velho Mundo já preconizavam a recorrência ao exame de escarro e mesmo ao Raio X para diagnosticar a infecção tísica, o professor Antonio Austragesilo (1908) - docente da Faculdade de Medicina do Rio de Janeiro - ensinava que a melhor estratégia para o reconhecimento da fimatose consistia na percussão do tórax do paciente com "um lapis commum ou um estylete qualquer”, "antes de qualquer observação”. Caso o enfermo acusasse dor na região perscrutada, lá certamente se encontraria a sede da infecção de Koch.

Com o decorrer dos anos, a tendência imitadora dos modelos clínico-cirúrgicos esboçados sobretudo na França consolidou-se como padrão orientador dos médicos brasileiros. No início dos anos 30, a cristalização dos debates nacionais em torno dos enunciados da tisiologia francesa chegou a tal ponto que muitos profissionais da saúde se negavam a discutir as experiências realizadas em outros centros científicos da Europa e dos Estados Unidos.

No ano de 1932, quando o Dr. Tisi Netto foi indagado por um jornalista sobre a eficácia de um remédio contra a tuberculose desenvolvido na Alemanha, o clínico paulista manifestou-se incapaz de avaliar a descoberta. Na continuidade, o médico declarou a vários órgãos da imprensa desconhecer as pesquisas germânicas, acrescen- 
tando que "aqui no Brasil, a litteratura scientifica que acompanhamos, com segurança e repetidas informações, é a litteratura francesa”.

A francofilia assumida pela medicina brasileira, quando ameaçada, tornou-se causa de discórdia no interior da comunidade tisiológica paulista. O médico Eduardo Etzel (1987), um antigo cirurgião do Hospital do Jaçanã, informou que o motivo que fez a Irmandade da Santa Casa de Misericórdia inaugurar o Sanatório São Luiz Gonzaga deveuse ao surgimento de uma desavença doutrinária entre seus principais colaboradores.

A maior parte dos clínicos que prestava serviços no Hospital Central da Santa Casa era filiada à escola francesa, aceitando com reticências a companhia do médico Alvaro Lemos Torres, que havia realizado cursos de especialização nos Estados Unidos. A situação tornou-se ainda mais crítica a partir do momento em que o professor Lemos Torres passou a instigar seus alunos da Faculdade de Medicina a se guiarem pelos manuais norte-americanos, o que resultou na exclusão do médico e de seu grupo de discípulos do Hospital Central. Foi-lhe então entregue o antigo Leprosário do Guapira para lá instalar um sanatório para tuberculosos. Assim, segundo o Dr. Etzel, nasceu uma das mais renomadas casas de saúde do Brasil.

No desenrolar do confronto, a facção mais significativa dos tisiologistas bandeirantes manteve-se leal à tradição francesa e parcialmente à italiana, fechando os olhos para as novidades produzidas nos outros países. Importantes recursos desenvolvidos pela Saúde Pública tardaram a ser incorporados à prática dos especialistas nacionais, comprometendo a eficácia de atuação de uma área do conhecimento por si própria ferida por perigosas lacunas.

Neste contexto, dentre os recursos desprezados pelos higienistas locais encontrava-se a bioestatística, técnica que havia ganho sofisticação na Inglaterra e nos Estados Unidos e que, no Brasil, durante muito tempo, resumiu-se à distribuição do número de casos de enfermidade segundo as variáveis do espaço e do tempo.

Mesmo o Instituto de Higiene paulista, filiado desde seu nascimento à medicina norte-americana por meio da Fundação Rockefeller, manteve-se afastado das análises quantitativas, apesar de ter sido o Dr. Paula Souza - um dos luminares desse centro de pesquisa - o orientador da tese de doutorado de Walter Leser, a qual marcava pioneirismo ao emprestar recursos da matemática para analisar os eventos epidemiológicos. Na introdução desse trabalho acadêmico, o Dr. Leser (1933) explicou o objetivo de seu estudo: “apresentar as principais aplicações dos métodos estatísticos à medicina e à higiene”, já que reinava uma grande indiferença no meio científico em relação a esta questão.

No tocante às atividades clínicas, o apego francófilo também se fez sentir negativamente. $\mathrm{O}$ interesse pelo tratamento da doença consuntiva parecia não incentivar o enriquecimento do saber sobre as demais enfermidades que afetavam o funcionamento pulmonar, resultando em freqüentes diagnósticos equivocados.

A constatação da existência de pacientes não consultivos que tinham sido isolados em ambientes sanatoriais fez com que, em 1941, a Faculdade de Medicina da Universidade de São Paulo incumbisse os Drs. Floriano de Almeida e Carlos da Silva Lacaz (1942) da tarefa de analisar o fenômeno. No final do processo, os clínicos chegaram a uma conclusão constrangedora, pois ‘desmeritória’ para a propalada “escola paulista de tisiologia”: de regra, os especialistas em tuberculose desconheciam a maior 
parte das micoses que comprometem o trato respiratório, situação que os fazia declarar consuntivos pacientes que padeciam de outras patologias.

Apesar da fragilidade da tisiologia brasileira, o agrupamento dos especialistas foi marcado pela constância de debates entre as vertentes doutrinárias que também agitavam a Higiene Pública e a 'medicina colonial' francesa. O que se constituiu certamente no principal foco nacional de celeuma referia-se à validade do clima como elemento terapêutico eficiente para os infectados. Desde que Brehmer e Dettwiller estabeleceram os primeiros sanatórios nas montanhas européias, a questão climatoterápica consolidou-se como tema polêmico, aflorando em momentos específicos, como motivo de disputas.

No Brasil, desde a última década do século passado o problema foi assunto de discussões, resultando porém em debates de escassas conseqüências. A dúvida sobre o valor do 'tratamento pelos ares' foi retomada somente na abertura dos anos 30 , quando da inauguração do Hospital do Jaçanã que, fugindo à regra até então seguida, estava situado nos subúrbios da capital paulista. Apesar de o nosocômio se localizar nas 'franjas' da Serra da Cantareira - domínio que guardava alguma semelhança com o de Campos do Jordão - inúmeras foram as vozes que se levantaram para denunciar como desarrazoada a decisão de instalar um sanatório numa região relativamente afastada das estações de cura situadas no território bandeirante.

A situação ganhou ainda maior intensidade quando o assunto foi incorporado às discussões veiculadas nas páginas da Revista Paulista de Tisiologia. O questionamento sobre o melhor local para a instalação de sanatórios recebeu divergentes respostas, estimulando a Associação Paulista de Medicina a promover um ciclo de debates sobre a validade dos princípios climatoterápicos. Um dos resultados deste movimento foi a publicação de um livro que enfeixava os textos elaborados para o debate, obra que exacerbou ainda mais a polêmica entre os especialistas, inclusive porque foi patrocinado por cerca de quinze laboratórios que comercializavam drogas contra a tuberculose (Souza, 1936).

Na série de conferências, realizadas a partir de maio de 1935, percebe-se que as discussões sobre o valor terapêutico do clima estavam contaminadas pelos interesses econômicos dos grupos que vinham enriquecendo com a exploração das instituições de saúde instaladas nas prefeituras sanitárias. A partir disto, mais que a defesa dos ares como recurso terapêutico das cavernas pulmonares, vários tisiologistas empenharamse em defender a continuidade de seus negócios centrados na Peste Branca.

Assim, a tendência geral dos clínicos e dos higienistas que atuavam nas cidades de São Paulo e Rio de Janeiro era reconhecer que o ambiente montanhoso atuava no refortalecimento dos ‘organismos debilitados' sem, contudo, garantir a recuperação da saúde das vítimas do bacilo de Koch. Alguns palestrantes, como os Drs. Paula Souza e Aloysio de Paula, asseveravam que a fé no potencial terapêutico do clima havia perdido confiança entre os facultativos, resistindo apenas como 'crendice popular'. Para estes tisiologistas, a única medida eficiente contra a tuberculose consistia na combinação do isolamento sanatorial e intervenção cirúrgica, independente do padrão morfoclimático da região onde os hospitais estivessem localizados. 
Para tornar ainda mais tensos os debates, Clemente Ferreira - que anteriormente havia se distinguido como intransigente defensor da climatoterapia - aproveitou o ciclo de conferências para declarar que o propósito de instalação de sanatórios nas montanhas era guiado por critérios de ordem econômica e política, acrescentando que somente os tísicos endinheirados reuniam recursos suficientes para prolongar a permanência na Serra da Mantiqueira. Mais ainda, o Dr. Ferreira colocou em dúvida as propriedades curativas do clima, informando que a medicina não dispunha até aquele momento de elementos confiáveis para comprovar a eficiência do tratamento realizado nos 'terrenos de altitude'.

Em oposição, insurgiram-se os médicos que atuavam nas tisiópolis de São José dos Campos e de Campos do Jordão. O Dr. Ruy Dória, que sempre se apresentara avesso aos debates clínicos, saiu das sombras de diretor-proprietário de uma casa de saúde na estação joseense para comandar os brados contestadores contra a dilapidação do ideário climatoterápico, não hesitando pela vez única em sua vida de se confrontar com os mais renomados tisiologistas do país.

Exibindo-se como representante dos sanatórios e dos facultativos que clinicavam nas estâncias de cura, o Dr. Dória discorreu sobre o mérito terapêutico do clima do Vale do Paraíba e da Serra da Mantiqueira para a maior parte dos fimatosos, avaliando negativamente a localização dos nosocômios nas periferias metropolitanas. Referindose implicitamente ao Hospital do Jaçanã, o médico de São José dos Campos observou:

Assim, é uma collina qualquer nos arredores de cidade grande que passa a substituir quasi grotescamente o clima de altitude, ou é um arrabalde um pouco menos populoso que figura como succedaneo do clima de planicie (...) julgamos que reconhecida a influencia dos factores climaticos, se encontrar em melhor condições de tratamento em Campos do Jordão do que na Cantareira, um doente cujo caso se enquadra nas indicações de cura de altitude.(1936:62)

Não de todo satisfeito com a justificativa que ele próprio declinara, Ruy Dória anexou aos seus argumentos uma extensa e variada lista de casos clínicos em que o pleno restabelecimento da saúde deu-se rapidamente, às vezes sem qualquer tipo de apoio medicamentoso que não fosse o repouso absoluto e o clima que bafejava as prefeituras sanitárias do estado de São Paulo.

O médico igualmente serviu-se da participação nos debates para expor um arsenal de motivos paralelos para advogar a instalação de sanatórios exclusivamente nas duas estações de cura que representava: o fator psicológico do isolamento dos infectados em áreas distantes, fazendo com que os pacientes se preocupassem menos com suas famílias; a vigilância contínua e a reeducação dos consuntivos, só conseguidas em casas de saúde afastadas do burburinho e da agitação metropolitana e, principalmente, a retirada dos tísicos dos centros urbanos, operação que inibiria a disseminação do bacilo da peste.

Em conclusão, o médico do Vale do Paraíba sugeria que a terapêutica climática era o principal e mais seguro recurso para o tratamento dos tuberculosos, criticando por sua vez as tentativas cirúrgicas e quimioterápicas de cura dos infectados, as quais o Dr. Dória diagnosticou como de 'valia reduzida', quando ministradas em territórios com condições climáticas ‘impróprias’ para os consuntivos. 
Outra questão que deu redobrado vigor aos debates tisiológicos referiu-se à vulnerabilidade das raças humanas frente à contaminação kochiana, assim como a capacidade dos brancos, negros e amarelos desenvolverem a enfermidade e se recuperarem ou falecerem em conseqüência da tísica. A especificidade racial, enfatizada pelo movimento eugenista, tornou-se um dos principais eixos discursivos sobre a 'nacionalidade’ brasileira, cabendo à medicina conferir legalidade científica a uma possível biologia diferenciadora dos grandes grupos humanos frente aos fenômenos patológicos.

Conferindo encaminhamento próprio aos debates realizados no exterior - que se mostravam cada vez mais reticentes em aceitar a tese sobre a condicionante racial como elemento significativo no processo tuberculoso - tornou-se comum no contexto nacional considerar que os negros e os mulatos compunham o agrupamento humano mais propenso ao desenvolvimento das moléstias em geral e da tuberculose em particular.

As primeiras reações clínicas a esta perspectiva ocorreram em 1934, durante a realização do Primeiro Congresso Afro-Brasileiro, quando o clínico Alvaro de Faria abordou o tópico, anunciando não haver comprovação científica alguma da propalada 'fragilidade racial' dos negros em relação à fimatose pulmonar. O médico informou que a maior incidência da tísica entre os 'homens de cor' devia-se à recente incorporação dos negros à 'civilização' e ao cotidiano do ambiente citadino, fenômenos que estimulavam o estreito contato entre os indivíduos sadios e os infectados, situação que favorecia o contágio (Faria, 1935).

O mesmo expositor acrescentou ainda que o ‘déficit nutritivo’ que caracterizava a população pobre e de origem africana era um fator co-responsável pela disseminação da enfermidade entre os negros e mestiços brasileiros. Qualquer outra possibilidade explicativa para o fenômeno da infecção tísica foi rejeitada pelo facultativo, pois, segundo ele, obrigatoriamente convergia para o preconceito e para a desqualificação social da comunidade com raízes fincadas na África.

Apesar da ausência de observações detalhadas sobre a presença da tísica entre os brasileiros negros e mulatos, o tema se manteve controverso, sendo que no final dos anos 30, vários especialistas voltaram a discuti-lo, durante a realização do Primeiro Congresso Nacional de Tuberculose. A presença de Alvaro de Faria na direção dos debates não foi suficiente para garantir a harmonia do encontro, pois, enquanto este especialista continuava advogando a tese com base no conceito de virgin soil, alguns outros estudiosos localizavam as diferenças da biologia racial como fator explicativo da alta incidência do Grande Mal entre a população afro-brasileira. Afastados dos debates públicos nos primeiros anos da década, os intelectuais que advogavam a condição de inferioridade da raça negra em relação aos brancos ganharam novo incentivo e voz com a ascensão do nazismo na Europa, interferindo nos debates tisiológicos.

Seguindo esta linha de entendimento, o médico paraense Henrique Esteves opôs-se às idéias esposadas pelo Dr. Faria, asseverando que a comunidade de origem africana era biologicamente mais susceptível à infecção que a branca, assim como os negros e os mulatos respondiam negativamente às variadas estratégias terapêuticas, chegando a óbito em um tempo muito menor que os contaminados de outras raças. Após a análise de dezenas de consuntivos negros, Esteves (1939) explicou a incidência 
da Peste Branca entre os indivíduos de sangue africano como um fenômeno exclusivo e de origem "possivelmente bioquimica ainda desconhecida", fato que permitia o "bom desenvolvimento do bacilo".

A intensidade das opiniões que alimentavam os debates exigiu que os médicos paulistas saíssem do isolamento e incorporassem a variável racial em suas averiguações sobre a Peste Branca. Os clínicos Souza Soares e Lincoln Faria (1939) inauguraram a série de estudos locais, tomando para análise não a comunidade negra, mas sim um grupo de cerca de 500 japoneses e seus descendentes que, radicados no estado de São Paulo, foram diagnosticados fimatosos.

A principal conclusão emitida pelos dois tisiologistas surpreendeu a todos, abrindo novo campo de discórdia entre os especialistas: a 'raça amarela' era tão vulnerável à infecção pulmonar quanto a negra, esclarecendo ainda que as condições de vida que marcaram o processo migratório em nada tinham influenciado as taxas de morbimortalidade dos grupos de japoneses que haviam se transferido para o Brasil.

Alguns anos depois, João Grieco (1942), clínico do hospital São Luiz Gonzaga, acrescentou novos elementos à questão ao considerar a pesquisa realizada pelos Drs. Soares e Faria como trabalho de pouca credibilidade acadêmica, colocando em dúvida não só a precisão dos dados quantitativos analisados, como também o pensamento explicador da saúde coletiva que renega as condicionantes culturais e socioeconômicas.

Nesta cirurgia, o Dr. Grieco buscou corrigir as conclusões esboçadas anteriormente pelos seus pares, anunciando que o perfil tisiológico dos homens de pele amarela aproximava-se ao dos negros e que isso não ocorria devido a qualquer determinismo biológico, mas sim porque, no contexto nacional, os representantes de ambas as raças tendiam a ocupar as tarefas mais árduas e de menor remuneração e, por extensão, desconheciam as regras elementares de higiene e de prevenção do contágio kochiano.

Delineava-se assim a linha mestra dos ensaios médico-sociais que, combinando doença, miséria econômica e padrões culturais destoantes com a modernidade, definiam as principais moléstias infecto-contagiosas como marca dos indivíduos insuficientemente preparados para viver nos grandes centros urbanos do país.

Identificado com a medicina norte-americana e com as mensagens políticas expedidas pelos países que compunham o grupo de Aliados na Segunda Guerra Mundial, o trabalho do Dr. Grieco foi alvo de vários prêmios acadêmicos, condenando seus opositores ao ostracismo.

Representando o paradigma de outras pesquisas sanitárias, o texto assinado por João Grieco refletia a opção tisiológica americanizada do Sanatório do Jaçanã, favorecendo a substituição das análises centradas no papel diferenciador das raças pelos estudos que focavam os grupos pobres e 'incultos' de migrantes nacionais, especialmente os nordestinos, como as principais vítimas e também como agentes disseminadores da moléstia do peito nos ambientes metropolitanos.

O próprio doutor Grieco assinalou que, com a paralisação da imigração estrangeira, a capital bandeirante estava recebendo significativos contingentes de migrantes, que se deslocavam das mais diferentes regiões do Brasil para tentar a sorte no estado de São Paulo. Infectados pouco depois de se estabelecerem na 'cidade grande', os 
recém-chegados atuavam como agentes propagadores da Peste Branca entre os paulistanos antigos, inclusive porque a principal ocupação encontrada pelos novos habitantes da urbe constituía-se nos serviços domésticos. Seguindo esta linha de entendimento, o clínico explicou a eventualidade da tísica atingir os lares mais abastados, acusando os serviçais de virtuais algozes dos filhos da riqueza.

A nova orientação sanitária fez com que os olhos epidemiológicos se detivessem na figura do migrante como força perpetuadora da tuberculose nas cidades mais populosas do país. Mesmo antes das observações de Grieco, o tema já vinha sendo minuciosamente examinado pelo Instituto de Higiene da Universidade de São Paulo, desdobrando-se em uma pesquisa dirigida pelo professor Rodolfo dos Santos Mascarenhas e datada do ano de 1939, mas que só recebeu divulgação uma década após o seu encerramento.

Nesse estudo que enfatizou a necessidade de investigações de campo na área da saúde coletiva, o Dr. Mascarenhas acompanhou sucessivos agrupamentos de migrantes oriundos do norte e do nordeste do país e que haviam sido alojados na antiga Hospedaria dos Imigrantes, sendo todos eles averiguados por uma equipe de médicos treinados especialmente para esta tarefa.

Após a realização de exames que avaliaram a incidência de reações positivas à tuberculina, o professor Mascarenhas concluiu que, diferentemente do esperado, os migrantes que se estabeleciam no estado de São Paulo não se tornavam vítimas do ambiente poluído pelo bacilo de Koch que existia nos centros urbanos de maior porte. Pelo contrário, os forasteiros alcançavam as cidades sulistas já corroídos pela enfermidade, tornando-se disseminadores da patologia pulmonar. Por isso, as opções do governo estadual, ainda segundo o Dr. Mascarenhas, eram limitadas:

A medida imediata a ser efetuada ser o exame roentgenfotográfico de todos os imigrantes chegados a São Paulo, quer se trate de nacionais ou de estrangeiros. Uma vez reconhecido como tuberculoso, o imigrante deve ou ser rejeitado ou ser encaminhado a um sanatório, ou ainda ficar sob tratamento e vigilância dispensarial. (1950:108)

Apesar da exposição dessas alternativas, o professor da Universidade de São Paulo parece que optou pela proibição da entrada de infectados no território bandeirante e o pronto retorno dos fimatosos para as suas áreas de origem. Isso porque o tisiologista esclareceu que, apesar de o governo estar naquela época despendendo esforços em prol da saúde pública, o estado não dispunha de recursos econômicos suficientes para: "suportar, sòzinho, o "nus do isolamento do imigrante nacional tuberculoso, sem prejuízo de suas demais campanhas sanitárias" (Mascarenhas,1950:109-110).

Um outro foco de celeuma que atingia os tisiologistas nacionais correspondia aos limites legais da intervenção médica, ganhando destaque os possíveis efeitos da gravidez sobre o processo consuntivo. A doutrina internacional ensinada aos juristas e aos clínicos pontificava que o evento gravídico atuava como fator estimulante das lesões tuberculosas, suportando, porém, que o aborto era crime e que, portanto, mesmo que a prenhez concorresse para a piora do estado da mulher infectada, a gestação deveria ser preservada. 
Chegado o momento do parto, caso houvesse risco de vida do nascente, a mãe enferma deveria ser sacrificada em favor da preservação da vida do filho que, afinal, poderia estar imune à infecção kochiana. Assim, a vida da mãe enferma daria lugar a uma existência possivelmente sadia do filho (Schwarcz, 1938).

Entretanto, especialmente entre os clínicos cariocas, surgiu a versão de que a gravidez não interferia no processo consuntivo, ressalvando apenas que os filhos de mães ou pais tuberculosos viriam à luz debilitados e com altas chances de contrair a tuberculose nos primeiros anos de vida.

O professor Mac Dowell (1939) estimulou ainda mais as divergências, alegando em diversos momentos que, inversamente ao que era propagado, a prenhez constituíase em um elemento dinamizador da cura das mulheres tísicas. Seguindo esta explicação, o facultativo asseverou que muitas de suas pacientes contaminadas recuperaram a plena saúde, sem qualquer tipo de tratamento clínico ou cirúrgico, apenas pelo fato de terem engravidado e dado à luz.

De qualquer forma, existem indícios de que o aborto era a recomendação que a maior parte dos médicos oferecia às pacientes consuntivas que engravidavam. Entre os facultativos paulistas, a questão manteve-se alijada dos debates, apesar de que, sutilmente, a Revista Paulista de Tisiologia, dedicada à especialidade, buscou estabelecer um posicionamento favorável ao aborto terapêutico. Uma prova disso foi a publicação de um artigo assinado pelo Dr. Almeida Gouveia (1936), clínico radicado na Bahia, no qual o autor combateu veementemente a prática do aborto entre as mulheres infectadas, mas, ao mesmo tempo, ensinou sutil e meticulosamente as técnicas que poderiam ser empregadas pelos profissionais da saúde para interromper a indesejada gravidez.

As questões legais suscitadas pelos praticantes da medicina multiplicavam-se aceleradamente, abrindo a cada instante novos pontos questionadores da justeza da doutrina tisiológica. Desacertos de avaliações sobre as linhas que deveriam ser assumidas pela administração de Saúde Pública, a necessidade de isolamento forçado dos enfermos, as modalidades de tratamento dos pectários e até mesmo a legalização da prática de eutanásia nos casos de tuberculose terminal favoreceram a discórdia entre os discípulos de Hipócrates.

Os desentendimentos permitiam inclusive a existência de momentos de delação de rivais frente às autoridades varguistas, reproduzindo no interior da academia as práticas policialescas que marcavam a administração federal. Como exemplo, tem-se as críticas realizadas ao movimento que deu origem à Associação dos Sanatórios Populares de Campos do Jordão, liderado pelo médico Raphael de Paula Souza.

Como era o clínico dos infectados residentes em Campos do Jordão, o Dr. Paula Souza foi o responsável por uma campanha que, escudada na idéia de que as casas de saúde filantrópicas não precisavam contar com um aparato rebuscado que caracterizava as instituições destinadas aos pacientes pagantes, propôs uma série de opções administrativas e arquitetônicas que, rebaixando o custo dos prédios onde deveriam ser isolados os tísicos, viabilizava o atendimento de um maior número de doentes pobres.

O resultado disso foi a criação, em 1931, da primeira unidade nosocomial, conhecida popularmente pelo nome de 'Sanatorinhos', exatamente porque o novo abrigo para 
consuntivos constituía-se em um simples barracão, contrastando com o estilo monumental dos edifícios que acolhiam os fimatosos endinheirados.

Como primeiro presidente da nova entidade, o professor Paula Souza criticou, em relatório referente ao ano de 1934, os gastos desnecessários que outras entidades particulares ou caritativas estavam realizando com a construção de hospitais luxuosos, concluindo que o 'lado aparatoso' do tratamento dos tuberculosos era supérfluo, resultando apenas na elevação dos custos assistenciais e, pior que isso, na escassez de leitos gratuitos aos pectários destituídos de amparos econômicos.

Nos primeiros momentos de vida dos Sanatorinhos, foram raros os médicos jordanenses que concordaram com a proposta do Dr. Paula Souza. Apenas os clínicos Clovis Corrêa, Vicente Marcílio e Lincoln de Faria - que atuavam no Posto de Higiene local - mostraram-se favoráveis ao funcionamento da casa de saúde para os enfermos desamparados, enquanto os demais facultativos manifestaram desinteresse ou aversão pelo movimento.

Em continuidade, em 1939, alguns tisiologistas identificaram publicamente o projeto de Paula Souza com o modelo assistencial proposto pelos socialistas europeus, fato que levou o diretor dos Sanatorinhos e seus seguidores a serem tachados de 'oposicionistas' e 'esquerdistas', termos que contavam com uma carga incriminadora e portanto perigosa, numa conjuntura que se identificava pelo regime ditatorial.

A multiplicidade de desacordos que pautavam as relações dos tisiologistas atuantes em São Paulo e destes com seus pares de outros estados, especialmente do Rio de Janeiro, estabeleceu os limites da prática médica e da administração sanitária centrada na Peste Branca. As questões que impregnavam as pautas de discussões superavam em muito as incertezas exclusivamente técnicas, confundindo-se com interesses particulares e com o clima político do momento. Assim, o período que se encerrou com o advento do primeiro quimioterápico eficiente contra a tuberculose caracterizou-se pela existência de uma medicina que se consumia em disputas internas, tornando difícil a articulação de um movimento tisio-sanitário em escala nacional.

A precariedade dos recursos preventivos e curativos contra a patologia pulmonar somava-se aos conflitos que paralisavam a comunidade dos tisiologistas e ao gerenciamento público deficiente das questões suscitadas pelo Grande Mal, condenando a especialidade a um comprometedor grau de defasagem em relação às outras nações. Os recursos necessários para a realização de diagnósticos precisos e tratamento dos pectários eram raros e concentrados nos poucos centros médicos do país. Para o geral da população, a clínica dispunha de princípios gerais de atendimento, os quais se mostravam de pouca serventia, mesmo porque mantidos inalterados desde o final do século passado.

Afora isto, o prestígio nacional granjeado pela 'escola paulista de tisiologia' não era fruto da coerência de sua proposta doutrinária. Os obstáculos para se alcançar consenso regional sobre o encaminhamento a ser dado aos principais problemas gerados pela Peste Branca conduziram uma parcela significativa dos especialistas de São Paulo a optarem pela intervenção cirúrgica como recurso básico que demandava pouco tempo para a possível cura pulmonar ou que, pelo menos, contribuía para a extensão da sobrevida dos infectados. 
Tendência universal a partir da década de 30, a orientação operatória para o tratamento dos consuntivos ganhou dimensões abrangentes no Brasil e especialmente em São Paulo, fato que colocou em lugar secundário as recomendações médicas que apontavam para a climatoterapia e para as soluções medicamentosas, inclusive os compostos de cálcio e de sais de ouro que, durante um breve período, foram considerados como substâncias ‘curadoras’ da tuberculose.

Apostando na positividade das operações torácicas, o Hospital-Sanatório São Luiz Gonzaga patrocinou a formação de uma equipe de tisiocirurgiões cuja eficiência repercutiu na definição da moléstia pulmonar. Apesar das pontificações que, na década de 40, versaram sobre a influência dos ‘padrões culturais' sobre a incidência da tísica, o encaminhamento preponderante entre os paulistas constituiu-se no enquadramento biológico da doença e na análise das trajetórias individuais dos pectários, marginalizando os questionamentos que, por meio da enfermidade, buscavam averiguar as desigualdades que davam características peculiares à formação social brasileira.

Neste contexto, a educação em saúde despontava como medida preventiva viável para os grandes centros urbanos, pois estava voltada para a 'reforma' dos comportamentos individuais.

\section{Notas}

1 A Revista Paulista de Tisiologia foi publicada ininterruptamente até o final de 1945, quando teve sua circulação suspensa. A série voltou a ser editada em 1954, alterando sua denominação para Revista Paulista de Tisiologia e do Tórax, período em que perdeu seus antigos patrocinadores e transformou-se em publicação irregular até seu definitivo encerramento, ocorrido em 1965. O único periódico especializado na doença pulmonar criado antes da coleção paulista foi a carioca Revista Brasileira de Tuberculose, patrocinada pela Federação Brasileira de Tuberculose e inaugurada em 1932. 



\section{5}

\section{A Educação pela Tuberculose}

São Paulo, como cidade que emblemava o progresso brasileiro, reunia em seu contexto uma boa síntese dos direcionamentos nacionais. 'Moderna', 'industrial', 'cosmopolita’, a cidade era, naturalmente, um espelho fiel da problemática do país. A afluência de imigrantes e de migrantes convertia São Paulo em centro de fundamental importância para o enlace de questões que, afinal, extrapolavam as tensões internas brasileiras. Avanços da cultura e da ciência repontavam na capital dos paulistas, transformando-a em pólo de fermentação de idéias. A década de 30 do século passado é um eloqüente exemplo desta disposição - e a Universidade de São Paulo sua prova maior.

Vale, contudo, considerar que, independentemente do direcionamento identificado em São Paulo dos anos 30, havia uma anterioridade na vivência internacional e mesmo nacional com as questões pertinentes ao setor que, nas décadas recentes, recebeu o nome de ‘educação em saúde’. Pressuposto obrigatório para o entendimento da 'filtragem' da tuberculose como personagem, entre nós, é a análise desta situação.

\section{As Raízes da Prática Educativa em Saúde}

A partir de meados do século XIX, a medicina européia intensificou a busca de apoios nas técnicas pedagógicas, visando, com isso, a traçar estratégias de convencimento individual e coletivo sobre a urgência de reorganização da vida no contexto da cidade industrializada. A necessidade de construção de um 'ser' coerente com a modernidade e ao mesmo tempo avesso aos quistos de devassidão instalados nas cidades ensejou o florescimento do discurso educador em saúde. Assim, ganhou expressão uma multiplicidade de mensagens que, no mesmo compasso que bendizia a metrópole industrial, também confidenciava a nostalgia frente ao esmaecimento dos amparos comunitários e do zeloso moralismo garantidos pela tradição.

Como prática discursiva centrada na problemática dos grandes centros urbanos, o ensinamento higienista buscou impor, valorativamente, os conselhos que outrora eram ministrados pelos pais, padres e professores. Em nome da 'verdade científica', a medicina reclamava o direito de comando exclusivo das ações que tinham como 
objetivo estabelecer e divulgar as regras sanitárias que deveriam reger o comportamento individual e garantir o bom funcionamento da existência coletiva.

O manual que ensinava a cuidar da saúde assinado pelo médico Paul Good (1923) talvez seja o melhor exemplo deste posicionamento que falava dos 'novos tempos’ com os olhos temerosos e melancólicos de um mundo que se transformava rapidamente. Traduzido em quinze idiomas, o texto do Dr. Good pretendia chamar a atenção dos jovens proletários para o perigo das enfermidades que poluíam as áreas urbanas, ensinando-lhes que as disposições higienistas eram produtos genuinamente derivados das leis morais.

A identificação da saúde do corpo com a correção do espírito colocava em foco a opção individual de encaminhamento da vida, abrindo oportunidade para a conclusão de que somente aqueles que cediam ao ócio, aos vícios e às tentações sensuais é que se tornavam fáceis presas do conjunto de patologias que sangrava o terreno metropolitano.

O fato da tuberculose ser considerada 'doença social' - e, portanto, limitada pelo regramento moral - determinou que a ampla disseminação da Peste Branca fosse tomada como argumento incentivador dos primeiros movimentos de educação em saúde. Como resultado, tanto nos Estados Unidos quanto na França, a ameaça tísica suscitou a criação de departamentos especializados na então chamada 'educação sanitária’, a partir do ano que marcou o encerramento da Primeira Guerra Mundial.

No Brasil, o acompanhamento das tendências internacionais na reorganização dos serviços de Higiene Pública ocorrida após o advento da República estabeleceu como obrigação exclusiva do diretor do Instituto Sanitário Federal a tarefa orientadora da população, limitando este compromisso às quadras definidas pelas crises epidêmicas.

Foi somente no ano de 1921, por meio de uma nova reforma do setor saúde, que o país passou a contar com um órgão denominado Serviço de Educação e Propaganda Sanitária, encarregado de elaborar material didático destinado a instruir os cidadãos sobre os meios de evitar as pequenas e as grandes patologias que assolavam as áreas de concentração humana.

Consultas aos arquivos desta repartição demonstram que ela cumpriu acanhadamente seus objetivos, pelo menos no transcorrer da primeira década de funcionamento. Isso porque o Serviço de Educação e Propaganda Sanitária restringiu-se quase que exclusivamente a traduzir e editar as mensagens elaboradas no exterior, sem ao menos tentar adaptá-las à problemática brasileira, repetindo os folhetos preparados pela Comissão Rockefeller e pela Cruz Vermelha e distribuídos na Europa a partir do ano de 1919.

\section{Os Primórdios da 'Educação Sanitária' em São Paulo}

A demora na ativação de um movimento oficial de orientação popular sobre os perigos do contágio consuntivo levou o médico Clemente Ferreira a, uma vez mais, ocupar posição pioneira no comando dos esforços educadores dos habitantes da cidade de São Paulo. O primeiro fruto do empenho da Liga Paulista Contra a Tuberculose em 
ensinar os princípios básicos de higiene à coletividade foi a publicação, em 1901, do texto preparado pelo médico norte-americano Samuel Knopf, acrescido de um capítulo assinado pelo Dr. Ferreira, no qual era ressaltada uma vez mais a ausência governamental na luta contra a doença pulmonar, fenômeno comum ao Brasil e a Portugal.

O insucesso do trabalho preventivo foi flagrante. A brochura distribuída gratuitamente à população era composta de 53 páginas preenchidas com letras minúsculas e um linguajar técnico que certamente condenaram o documento a ser peça ininteligível para a maior parte dos cidadãos.

Alguns anos depois, a Liga presidida por Clemente Ferreira voltou a incentivar a campanha educadora sobre a Peste Branca, desta vez fazendo publicar dois pequenos textos intitulados Instrucções Populares sobre a Tuberculose e Catecismo sobre a Tuberculose Destinado aos Operários, que somavam palavras de fácil entendimento e ilustrações coloridas de vermelho, deixando claro o objetivo de chamar a atenção da parcela trabalhadora das principais cidades paulistas.

Nestes novos empreendimentos, o Dr. Ferreira ensinou que a tuberculose constituía-se em moléstia causada exclusivamente por um micróbio e que a patologia “persegue principalmente os pobres, os operários e os artistas" (Ferreira, 1908), negando a importância da hereditariedade na perpetuação da doença entre as famílias proletárias. Além disso, o médico alertou que todos deveriam se precaver contra o 'mal dos pulmões', consumindo alimentos saudáveis e em abundância, além de buscar moradia em residências arejadas, evitar exageros físicos e mentais e fugir das bebidas alcoólicas. Como se todas essas medidas fossem de fácil acesso ao conjunto da população citadina.

A escassez de recursos foi indicada como elemento impeditivo para que a entidade anti-tuberculosa desse prosseguimento às atividades educativas. Apesar da inexistência de informações precisas, acredita-se que, a partir de 1915, a Liga Paulista tenha restringido suas tarefas de esclarecimento público ao preparo de cartazes que eram expostos em ambientes hospitalares e nos locais de aglomeração humana.

Neste processo, enquanto os 'catecismos' patrocinados pela associação ferreiriana ensinavam as regras elementares de higiene, as mensagens inscritas nos cartazes tinham como destino alardear a periculosidade representada pela permanência dos pectários junto aos sadios, especialmente ao contingente infantil.

Representando emissários da doença e da morte, aconselhava-se que muitas coisas deveriam ser vedadas aos tuberculosos: a companhia de não contaminados, a conversa prolongada, o beijo no rosto e especialmente na boca, o aperto de mão, a oportunidade de trabalho, enfim, a solidariedade próxima. Na seqüência, os comunicados sanitários instruíam os indivíduos saudáveis a se manterem afastados de tudo o que tivesse a marca da fimatose, inclusive das residências onde viviam os doentes e dos locais onde tivesse ocorrido óbitos causados pela Peste Branca.

O posicionamento da Liga Paulista Contra a Tuberculose como paradigma nacional incitou as entidades congêneres, sediadas em outros pontos do país, a produzirem folhetos e cartazes próprios, sendo que todos eles guardavam nítida semelhança com os que eram preparados em São Paulo.

No território baiano, a campanha sanitária elegeu o agrupamento infanto-juvenil como população-alvo de suas pregações, servindo-se da tísica para tecer regras sobre 
o que 'os meninos educados não deviam fazer'. A contínua reiteração do alerta 'nunca' - anunciado em letras destacadas - expunha a intenção coercitiva da propaganda, fazendo a apologia da conduta desconfiada para com todos, inclusive em relação às pessoas que partilhavam do círculo íntimo da vida doméstica. Neste encaminhamento, dentre os postulados divulgados pela Liga Bahiana (apud Ribeiro, 1956:72) Contra a Tuberculose, encontravam-se:

NUNCA beber agua no copo em que outra pessoa bebeu...

NUNCA permittir que qualquer pessoa lhes beije na bocca...

NUNCA beijar, abraçar, apertar a mão de um doente do peito...

NUNCA levar uma noite inteira accordado sem necessidade...

Após proceder ao alinhamento de uma infinidade de recomendações, os dizeres do mesmo cartaz lembravam aos incautos 'meninos': "NUNCA esquecer que, assim procedendo, mostram que têm educação e evitam muitas molestias entre as quaes a doença do peito".

A veiculação de orientações como estas não satisfazia plenamente os interesses da medicina dos anos 20, que situou a ampliação dos esforços de educação sanitária em massa como um de seus principais compromissos postergados pelo Estado. Apesar da constância das denúncias, a burocracia oficial fazia-se de surda frente aos reclamos, confirmando pelo silêncio a pouca eficiência do Serviço de Educação e Propaganda Sanitária e, em oposição, o importante papel das Liga Estaduais como centros fomentadores das mensagens preventivas.

Uma das raras tentativas oficiais de participar do setor educativo em saúde no período anterior a 1921 deu-se em São Paulo, no âmbito das atividades articuladas pelo Instituto de Higiene. No ano de 1918, graças ao apoio da Fundação Rockefeller interessada ao mesmo tempo em expandir a influência norte-americana na América Latina e garantir o prestígio da 'medicina científica' -, a entidade paulista inaugurou o funcionamento de um curso de formação de educadores sanitários, fazendo campanha para que as escolas de magistério incluíssem uma disciplina que discorresse sobre as regras básicas da saúde para os futuros docentes do ensino fundamental.

Como resultado, as unidades de educação elementar estabeleceram a instrução e a propagação dos postulados sanitários dentre os objetivos pedagógicos. Segundo um livro-guia organizado pelo inspetor do ensino estadual João Toledo (1925), ficava determinado que o programa de Higiene teria como finalidade promover a 'moralidade do educando', preparando as crianças para as tarefas de 'cidadão prestativo'.

Neste direcionamento, uma vez mais os ensinamentos preventivistas entrelaçavam-se com as regras morais, exigindo que os professores criassem condições para que os aprendizes "adquirissem homogeneidade psychica" que os permitisse compreender inclusive os motivos que levavam "alguns individuos a se entregarem a tuberculose" (Toledo, 1925:8 e 146).

O material norteador que deveria chegar às mãos dos docentes e dos alunos infantis consistia na Cartilha de Hygiene, elaborada em 1923 pelo próprio Instituto de Higiene, sob a coordenação do médico e jurista Antonio Ferreira de Almeida Junior que, na década seguinte, seria responsável pelas aulas de Biologia Educacional na Faculdade de Filosofia, Ciências e Letras da Universidade de São Paulo. 
Nas páginas desse livro de ensino, a moléstia consuntiva ganhou espaço privilegiado, reiterando as instruções que vinham sendo divulgadas pela Liga Paulista contra a Peste Branca.

No manual destinado às crianças, o horror à enfermidade desdobrava-se na rejeição aos tísicos, enfatizando a figura do infectado como um ser abjeto e assustador. As ilustrações guardavam íntima coerência com o texto, retratando o tuberculoso como um indivíduo feio, sujo, triste, alquebrado, perigoso, sendo o seu perfil muito próximo da representação clássica do Ceifeiro Implacável. Em contraste, a imagem do sadio confundia-se com os traços corporais cobrados dos filhos da burguesia: brancos, limpos, bem arrumados, vigorosos, musculosos, sorridentes, ativos e sempre dispostos ao trabalho.

A iniciativa paulista de confundir em um mesmo enredo o doente com o perfil da pobreza e da decadência moral e os saudáveis com a matriz comportamental acalentada pela elite, inevitavelmente projetou-se em outros estados, mesmo que nestes casos não houvesse o patrocínio da administração pública.

No Espírito Santo, por exemplo, o professor Collares Junior incluiu no seu livro de Moral e Civismo, publicado em 1930, um capítulo em que era retratada a trajetória de vida de um docente de escola primária que juntava às atitudes despóticas um semblante que lembrava a miséria econômica, sendo por ambos os motivos odiado pelos seus pupilos e também por seus familiares.

Após a minuciosa descrição do professor, Collares Junior decifrou as condicionantes da vida do estranho mestre, repartindo o segredo com uma legião de leitores quase crianças: o odiado professor tinha sido viciado pelo álcool na mocidade, motivo que o levou a se tornar fácil presa da tuberculose e também a ser pai de uma numerosa prole, toda ela composta por débeis mentais, aleijões, prostitutas e vagabundos, atribuindo-se ainda à infecção kochiana a 'prole degenerada' e a incapacidade do mestre de se relacionar afetuosamente com seus discípulos. Era com estas lentes embaçadas pelo preconceito que muitos estudantes entravam em contato com o personagem de pulmões corrompidos.

\section{As Alternativas Educadoras}

A ampla distribuição do Grande Mal nos ambientes urbanos contrastava com as fragmentárias e acanhadas tentativas educadoras que, ao se concretizarem, atingiam escassamente o público das cidades, inclusive porque o analfabetismo e o desconhecimento da língua nacional predominavam nos grandes centros urbanos do país. A crescente tisiofobia que animava os comportamentos sociais incitava a população a discutir as possibilidades da existência consuntiva, buscando motivos convalidadores dos preconceitos ajustados aos tributários da Peste Branca.

A leitura das fontes que guardam histórias de tuberculosos sugerem que tais narrativas foram contadas e recontadas em conversas grupais antes de ganhar registro escrito. Isto permitiu supor, num primeiro momento, que muitos destes fatos tivessem 
sido anunciados pela imprensa popular, tornando os jornais veículos disseminadores das notícias sobre os fracos do peito, sobrepondo-se em importância ao discurso médico-higienista articulado no período anterior à década de 30.

Os diários de São Paulo, entretanto, incorporando o direcionamento da imprensa nacional, pouco se ativeram ao personagem tísico, assumindo como regra a constante reprodução em suas páginas de textos assinados por clínicos e por laboratórios comprometidos com a causa da tuberculose, exponenciando os perigos do contágio, sem, contudo, abordar a possível periculosidade do personagem enfermo. Acompanhando estes artigos, havia também notas que informavam sobre as atividades desenvolvidas pelos movimentos filantrópicos de apoio aos infectados pobres.

Raros foram os instantes em que os principais jornais paulistas se reportaram aos estigmas produzidos em torno da condição fimatosa. Em uma das primeiras menções ao tema, em 1875, A Provincia de São Paulo serviu-se da imagem da patologia apenas como metáfora esclarecedora da notícia, intitulando de "Ouvido de phthisico" um texto que versava sobre a peculiaridade de um europeu sadio que ganhou fama por distinguir a marca de fábrica das armas, apenas ouvindo o som do estampido dos projéteis.

Em outros momentos, quando a notícia versava sobre o crescimento do número de cortiços na 'Metrópole do Café', o tuberculoso mantinha-se como personagem de referência obrigatória, reiterando-se então a associação entre doença pulmonar e vida desregrada e improdutiva.

O afastamento da imprensa das notícias centradas nos personagens consuntivos fez com que outras fontes documentais fossem consultadas. Na busca de apoios, a literatura nacional ganhou sentido revelador, pois, com ritmo diverso do que prevalecia na imprensa e imitando o modelo que projetou os irmãos Goncourt, cumpriu a tarefa de vasculhar os segredos da condição consuntiva, apresentando-se como desdobramento complementar do saber hipocrático.

Com isso, os escritores brasileiros tornaram-se indiscretos auxiliares dos esculápios, favorecendo a operação na qual a literatura apoiava-se nos princípios médicos para conferir peso realista aos seus enredos e a medicina, por sua vez, alimentavase das descrições ficcionais da vida e dos sentimentos dos infectados para justificar suas pontificações sobre a 'psicologia' diferenciada dos pectários.

As observações literárias igualmente auxiliaram na tarefa esclarecedora da população que, movida pela curiosidade e pelo medo, reclamava orientações sobre como se comportar frente aos enfermos dos pulmões. Todos, médicos e leigos, queriam saber sobre as condicionantes da vida contaminada pelo bacilo de Koch, recorrendo por isso aos textos ficcionais ou ouvindo 'causos', muitos deles tecidos pelos escritores de larga aceitação pública.

Estava aberto o caminho literário para a devassa da existência tuberculosa. Seguindo o modelo estrangeiro, os autores brasileiros buscaram inspiração no realismo cientificista para descrever a individualidade enfermiça. Nesta cirurgia, a pena literária serviu-se sobretudo de uma nova concepção de peste que, roubada dos ensinamentos tradicionais e das cogitações médicas, tingiu o pectário com cores berrantes, situandoo como uma ameaça constante para as coletividades aprisionadas nas malhas da 
modernidade urbano-industrial. Entre a fantasia e a vulgarização científica, a literatura brasileira ratificou a metáfora identificadora da tuberculose com o mal, oferecendo novos alertas aos sadios sobre os perigos resultantes do convívio com os 'entisicados'.

\section{A 'Literatura Tuberculosa'}

Um dos primeiros escritores nacionais a romper - pelo menos em parte - com a visão romântica sobre os adoentados do peito foi Machado de Assis (1957). Assumidamente evitando a incorporação de personagens tísicos em suas criações, nas raras oportunidades que Machado discorreu sobre o tipo consuntivo, tratou logo de decretar-lhe a morte, como ocorreu com a tuberculosa Maria Luísa, no conto A causa secreta, publicado em 1896.

Definida como a "velha dama insaciável, que chupa a vida tôda, até deixar um bagaço de ossos” (1957:112), a tísica aflorou como um mal associado à malignidade imputada ao homem moderno. Machado de Assis evitou divagar sobre os sentimentos íntimos que animavam o comportamento da infectada, mas o mesmo não ocorreu em relação ao marido da personagem que, apresentado como sádico, comprazia-se em amputar e lançar à fogueira animais vivos. Na continuidade do texto, o escritor deixou claro que a moléstia pulmonar ramificou em uma criatura "nervosa e frágil”, incapaz de suportar a perversidade do esposo.

Nas três décadas e meia que se seguiram à publicação do conto machadiano, nenhum outro literato situou o personagem tísico como vítima dos descalabros dos sadios dos pulmões. Os sucessores de Machado de Assis fugiram das considerações filosóficas de Quincas Borba para, em seu lugar, entronizarem o seu oposto, Borba Sangue, o personagem médico criado pelo também médico Neves-Manta (1930).

O novo paradigma explicador das tramas existenciais dos infectados foi pouco a pouco sendo construído neste intervalo de tempo, centrando suas conclusões na filha mais cara do positivismo clínico, a endocrinologia. Motivado pelo novo braço da medicina, que reduzira o corpo humano a um 'armário de glândulas', Borba Sangue não teve dúvidas ao pontificar: "a vida é um processo de experimentação. De equilibrio physio-glandular. De tendente equidade sociogenica. Domina-te! Corrige-te!” (Neves-Manta, 1930:109).

A obediência a este enunciado determinou que a comunidade dos ficcionistas emprestasse vigor próprio ao pressuposto hipocrático que localizava o tuberculoso no círculo vicioso que, inaugurado pela perversão dos costumes, conduzia à tísica, sendo a enfermidade então responsabilizada pelo aprofundamento da degradação dos sentidos e pela ampliação das tendências pervertidas. Por isso, os murgerianos Mimi e Rodolphe parecem inocentes demais se comparados aos pectários apresentados pela literatura brasileira. No contexto nacional, os personagens tuberculosos foram excessivamente diabolizados, conferindo uma identidade própria e aterrorizadora a um grande número de peças ficcionais compostas nas três primeiras décadas deste século. 
Espelhando esta tendência, no final do século XIX, o maranhense Coelho Netto (1924) produziu um conto onde o elemento tísico ganhou sentido na figura de Isidro, jovem burguês que, enviado a Portugal para graduar-se em Direito, aproveitou-se da ausência paterna para entregar-se à bebida, ao ópio e às orgias, encontrando abrigo carinhoso nos braços de uma linda cigana. Frágil do físico desde o nascimento, todos os exageros comprados a peso de ouro só poderiam levá-lo a um desfecho único: a hemoptise anunciadora da tuberculose.

Obrigado a retornar ao Brasil, pouco tempo Isidro permaneceu na cidade do Rio de Janeiro, sendo enviado pelo médico da família para o clima seco e fresco do sul da Bahia. Uma vez mais distanciado dos progenitores, o enfermo entregou-se à vida desregrada, agora não por vontade própria, mas sim em conseqüência da 'febre tuberculosa' que acreditava-se deformar os mecanismos do corpo e da mente, produzindo a depravação do comportamento.

Amasiado com uma mulata sensual, Isidro ao mesmo tempo infectou e engravidou a amante que rapidamente caminhou para o óbito. Concomitantemente à piora do estado da saúde do viajante, a tísica impunha ao seu súdito todas as suas marcas, inclusive o misticismo, levando-o a encontrar a morte no altar de uma capela sertaneja.

Nas linhas do conto assinado por Coelho Netto foram associados os principais estigmas atribuídos aos doentes do peito: vida dissipada, irresponsabilidade social, egocentrismo, hipersexualidade e 'loucura mística’. A partir de então, foram estes os temas explorados pela imaginação dos escritores nacionais que, iniciantes ou não, encontraram na exposição da pretensa trajetória de vida tuberculosa a garantia do sucesso editorial, oferecendo farto material que sugeria o funcionamento íntimo dos segredos que pontuavam a privacidade dos infectados.

Assim ocorreu com o estreante Théo-Filho (1923:62-123) que, no ano de 1910, obteve os primeiros reconhecimentos da crítica e dos leitores ao discorrer sobre a vida privada de alguns tipos cariocas, na coletânea intitulada Dona Dolorosa. Apresentada por Silvio Romero como uma obra que expunha “a vida como ella é na sua largueza ordinaria”, o conto que empresta nome ao volume centra a narrativa na descrição da atormentada Cecília, amasiada com o jornalista Julião, por sua vez um fracassado aluno da Faculdade de Medicina carioca.

Logo após efetivar a vida em comum, Julião passou a se torturar com a aparente frigidez sexual da companheira, ex-lésbica, que nos momentos iniciais da união com o jornalista limitava-se a realizar suas “satisfações mórbidas (...) pela imaginação, no vicio solitario”. Inquirida insistentemente pelo amante, Cecília confessou sua tara: o êxtase sexual só era alcançado se arrancasse e bebesse o sangue do corpo do companheiro. Feita a confissão, a mulher que os amigos apelidaram de Dona Dolorosa passou a apresentar um “monstruoso appetite genesico” e também inusitado apego religioso, já que até o sangue divino, estilizado no santo crucifixo, estimulava o prazer da ‘desregrada’.

Atormentado pela conduta da amásia, Julião recorreu aos alfarrábios que lhe restaram do curso de medicina para, em um momento de desespero, lançar suas suspeitas sobre a companheira: “Tenho nojo de ti. (...) Tens então lama nas veias, em vez de sangue! ... És um monstro... com certeza filha de monstros...”. 
Ato contínuo, o 'macho inútil' completou a sua insultuosa análise:“cobrindo de defeitos à mãe della, a todos os seus antepassados cheios de mazellas no sangue e nos nervos, talvez syphliticos, com certeza alcoolicos, quem sabe se não tysicos! Que familia torpe! E elle que se deitara com um trapo daquella dymnastia!”

A trama se desenrola fazendo do jornalista um detetive que, no final das investigações, descobriu uma série de fatos sobre o pretérito de Dona Dolorosa, coerente com as suas desconfianças: a mãe de Cecília era uma decadente e tuberculosa prostituta do Mangue, que vendia o corpo para sustentar o marido beberrão. Cecília havia sido gerada em um momento de embriaguez do casal, às vistas dos freqüentadores da casa de meretrício, nascendo menina fraca, marcada ela também pelo comprometimento pulmonar.

A aberração do comportamento da tísica Cecília foi apresentada como fruto natural da herança biológica familiar e da condição infectada. Para uma personagem assim tão carregada de estigmas, não restavam outras possibilidades senão o manicômio ou o necrotério. Théo-Filho optou pela segunda alternativa, fazendo a 'impudica Dona Dolorosa' suicidar-se, não sem antes uma vez mais entregar-se à 'maldição de Onan', com os olhos voltados para as chagas do filho crucificado de Deus, lembrando o desfecho que a francesa Jane de La Vaudère dera ao seu livro intitulado Os Androgynos.

A morte ou o hospício. Estes eram os caminhos que a literatura escolhera para os personagens fimatosos, selando a impossibilidade dos tuberculosos permanecerem no convívio com os sadios. Algumas vezes os escritores cruzavam as opções, como fez Pedro de Castro Canto e Mello, escritor que alcançou relativo sucesso com textos moralistas, tornando-se literatura recomendada para os alunos adolescentes dos internatos religiosos.

Em Almas em Delirio, editado em 1912, Canto e Mello incorporou a teoria médica segundo a qual a doença de Koch e a loucura eram patologias associadas, compondo o que ele próprio classificou como sendo um 'estudo psicológico'. Advogado de profissão, o escritor justificou o embasamento clínico de sua obra pelo fato de ter encontrado incentivo e orientação junto ao Dr. Franco da Rocha, diretor do então denominado Hospício dos Alienados do Juqueri, a quem o autor dedicou o livro.

Almas em Delirio foi anunciada como uma 'história verdadeira', tendo como personagem central um major do Exército, acobertado pelo pseudônimo de Rogério Duarte. Após ganhar distinção como herói nacional pela atuação na guerra do Paraguai e na Revolta dos Mucker, o militar contraiu casamento com Carolina, moça interiorana e rica, desejosa dos prazeres oferecidos pela metrópole.

Ambiciosa e egoísta, a mulher impôs ao marido uma 'comunhão satânica', exigindo que Rogério empenhasse todos os seus bens na aquisição de roupas, jóias, perfumes e em festas elegantes. Exaurido economicamente, o militar pouco a pouco se viu despojado de tudo, até da galhardia de herói nacional. Desgostoso pela 'má escolha da consorte', Rogério passou a ausentar-se do lar, varando noites nas tavernas e nos bordéis, até se tornar alcoólatra e toxicômano, recorrendo insistentemente ao parati, ao clorofórmio e ao ópio para minimizar os desgostos da vida.

A partir deste ponto, o leitor fica em dúvida sobre a veracidade dos fatos, já que a trama foi narrada na primeira pessoa do singular. Entre a alucinação e a realidade 
cerraram-se tênues cortinas que direcionam Rogério para a insanidade mental e para a tuberculose. Alucinado pela idéia de que Carolina o traía com o clínico encarregado de seu tratamento, o militar tenta assassinar o facultativo, sendo tomado em seguida por ‘agulhadas no peito’ e, na seqüência, pela hemoptise.

O manicômio configurou-se como o caminho imediato de isolamento, sendo que o doente permanece pouco tempo no hospício, até mostrar-se livre dos delírios. Porém, a devastadora tísica o obrigou a estabelecer moradia em Campos do Jordão, onde esperou a morte pôr termo às suas angústias. Ocorrido o óbito, os jornais paulistanos seguiram o protocolo, registrando falecimento do herói nacional como resultado de 'antigos padecimentos'.

Nessa trajetória, o major Rogério Duarte não foi apresentado como vítima de um casamento infeliz. Diferentemente da machadiana Maria Luísa, o personagem criado por Canto e Mello (1912:15) foi responsabilizado pelo ‘inferno’ em que se transformou sua vida, mensagem que desponta na introdução do ‘depoimento’ do frustrado herói militar: “Quando não tenha outro merecimento, servirá [o texto] ao menos de lição e de exemplo àquelles que sendo, como eu, talhados para o bem, se tornam, por sua culpa, enormemente desgraçados”.

A fantasia literária mostrava-se insaciável na exposição pública das aberrações pretensamente produzidas pelo bacilo tuberculoso. A percepção distorcida da realidade e a exaltação egocêntrica que animavam os figurantes consuntivos tinham como desdobramento novas versões ficcionais que declaravam-se instrumentos dissecadores da vida privada dos contaminados.

Este caminho de fácil exploração motivou também o desconhecido escritor Elias Cecilio, perene ausente das avaliações literárias sobre as primeiras décadas deste século. No seu livro Demonios e Semideuses, lançado no ano de 1933, a tuberculose dirige as ações de Aulo Santerre, um homem rico e de destaque no mundo dos esportes, que se apaixonou por uma pectária que escondeu até à morte a sua condição enfermiça.

Infectado, Aulo descobriu-se doente logo após tomar ciência da causa do repentino falecimento da amada. Em resposta à sua tragédia, o enfermo resolveu vingarse do mundo, empenhando o resto da sua vida na disseminação do bacilo de Koch. Para atingir este objetivo, o ‘perverso Aulo’ passou a promover contínuas festas que degeneravam em bacanais regados pelo absinto e pela morfina, exigindo nestes encontros que todos os presentes bebessem de um mesmo cálice, previamente contaminado pelo germe da morte. Próximo do fim, o consuntivo ocupou seus derradeiros instantes de vida locupletando-se de sua própria maldade, feliz porque havia 'marcado' todos os seus parceiros de devassidão.

As cenas de pretenso realismo sobre a conduta corrompida dos tísicos encontrou verificação maior em uma extensa passagem de um livro apresentado como coletânea de ‘crônicas policiais' e intitulado Noites de Plantão, sendo seu autor o delegado paulistano Amando Caiuby (1923).

Nesta obra, destaca-se o drama que envolveu Leopoldo e Olivia, um casal do interior paulista que perdeu todos os seus bens na busca da cura da doença pulmonar que minava Leopoldo. Moradores em Mogi-Guaçú, a miséria econômica e a tísica impu- 
seram a transferência do casal para a cidade de São Paulo, onde o tuberculoso esperava encontrar assistência médica patrocinada pela filantropia.

Leopoldo, no entanto, teve seu internamento hospitalar rejeitado pela Santa Casa, sendo obrigado a alugar um quarto num cortiço localizado no bairro operário do Brás. Na habitação coletiva, o doente logo selou inimizade com o senhorio, não só porque atrasava o aluguel, mas também porque sua tosse contínua amedrontava os demais inquilinos. Em resposta aos reclamos, o consuntivo esfaqueou um dos vizinhos, sendo encaminhado à chefatura da polícia.

Na delegacia central, Leopoldo foi acometido por uma violenta hemoptise, sensibilizando o delegado que não só o perdoou como ainda forneceu dinheiro suficiente para o casal mudar a residência para Campos do Jordão. Na estação de cura, o infectado deixou-se dominar pela 'tara consunptiva', mostrando-se enciumado pelos olhares cobiçosos que os sadios lançavam sobre Olivia. Ao perceber a proximidade da morte, o 'egoísmo' e a 'distorção dos sentidos' impostos pela tísica fizeram o doente fingir-se recuperado, para assim contaminar a acompanhante, pois, tomado também pela 'febre de sensualidade', Leopoldo forçou a esposa a lhe conceder íntimos 'agrados e carinhos'.

Atingido o lúgubre propósito, o fimatoso dominado pelo 'cérebro doentio', confessou à companheira:

- Filha, vou primeiro. Morro contente, porque sei que me acompanhas. Fingime são, para poder contaminar-te. Perdoe-me. Amei-te muito para deixar-te sosinha aos outros. (...) Os meus beijos mataram-te. És nova, não sofrerás tanto, acabarás depressa. Por despedida mais um beijo, aqui, na bocca... (Caiuby, 1923:40)

Quanto maior fosse a 'febre, e o suor frio, e a tosse, e o desespero', maior também seria a maldade dos infectados. Em coerência com este postulado, no livro de estréia do médico e escritor José Geraldo Vieira (1922), intitulado A Ronda do Deslumbramento, os vários personagens retratados carecem de nome próprio, sendo todos eles rotulados apenas pela identidade da doença que os afligia. No império enfermo visitado pelos literatos, os indivíduos perdiam destaque, constituindo-se apenas em apagados coadjuvantes que permitiam que a tuberculose, a grande personagem, pronunciasse na plenitude o seu poderio de deformação moral e de extermínio da raça humana.

Completando a tarefa decifradora do doente dos pulmões, os ensaios ficcionais também foram utilizados para descrever os traços físicos que tornavam possível o reconhecimento imediato dos perigosos filhos do Grande Mal.

Se o corpo emagrecido e o escarro sangüíneo foram os elementos mais constantemente invocados, outros detalhes eram anunciados como reveladores da condição enferma: as orelhas despregadas da cabeça, dentes escurecidos, audição afinada, unhas quebradiças, olheiras profundas, pele manchada, ombros caídos, pilosidade rara ou mesmo inexistente, corpo trêmulo, gesticulação exagerada, voz rouca e uso de roupas quentes nos meses de verão ou de pijama sob a roupa exibida publicamente.

Seguindo o compromisso identificador dos fimatosos, ainda nos anos 20, Amadeu Amaral compôs o seu Memorial de um Passageiro de Bonde, texto publicado postumamente, no qual o autor narra o cotidiano de um homem, sob o pseudônimo Felicio 
Trancoso (1938), nome também emprestado a um burocrata que se comprazia em observar seus companheiros de condução.

Na posição de espectador, Trancoso fantasiava conhecer na intimidade várias pessoas que compartilhavam com ele a viagem de bonde. Dentre os passageiros examinados, destaca-se uma mulher que o voyeur batizou com o nome de Rufina. A coincidência de ambos partilharem do mesmo veículo dia após dia, permitiu que Trancoso detalhasse em seu diário as características da mulher: vigorosa, sempre animada e sorridente, trabalhadora, enfim, plenamente sadia.

Uma manhã, porém, Rufina ausentou-se do bonde, fato que se repetiu por dois meses consecutivos. Esgotado este tempo, Rufina reapareceu, sendo imediatamente notada por Trancoso. Entretanto, ela não apresentava mais a vitalidade que havia excitado a imaginação do memorialista. $\mathrm{O}$ encanto feminino tinha se corrompido monstruosamente, sendo substituído pelo depauperamento do físico e pela palidez do rosto. O ‘regato da montanha' tinha sido depredado, tornando-se um lúgubre 'ribeirão turvo do vale triste'.

A brusca decadência do corpo e o estado de desânimo identificado pelos olhos do espectador não deixavam dúvidas. O diagnóstico feito por Trancoso garantia que a passageira do bonde havia sido aprisionada nas 'garras da bruxa horrenda e bela', a tísica. A doença de Koch fez com que o memorialista perdesse todo o interesse pela companheira de viagem, e por isso a pretensa enferma deixou de povoar as fantasias do burocrata.

A ânsia literária de dimensionar a condição tuberculosa impunha que não só o pectário, mas também os seus parentes próximos fossem apresentados sob a pecha da periculosidade e do desregramento. Idéia veladamente manifestada pela medicina, a defesa da existência de estirpes condenadas pela Peste Branca foi amplamente vulgarizada pelos escritores brasileiros, motivando a sociedade a se afastar das famílias em que houvesse casos da infecção.

Como exemplo, citam-se os conselhos emitidos por Otoniel Mota, um pastor protestante que ocupou o cargo de professor do Departamento de Letras da Universidade de São Paulo. Pai de uma tuberculosa e co-fundador de vários sanatórios protestantes, mesmo assim o professor Mota escreveu textos nos quais pregava a proibição de alianças entre famílias sadias e clãs assolados pela tísica, encobrindo-se sob o pseudônimo Bar Joseph (1936).

Em um de seus romances, que contou com sucessivas edições patrocinadas pela Igreja Protestante, o religioso colocou palavras de censura na boca de um de seus personagens, motivando-o a denegrir a intenção de casamento entre um rapaz cuja única mácula era ser sobrinho de um pectário e uma moça de estirpe sadia: “- Que direitos tem um rapaz de exigir da mãe de familia que lhe dê para o tálamo um corpo virginal quando ele só lhe pode oferecer em troco um corpo ascoroso, envilecido no deboche, corroido de molestias repelentes?” (Joseph, 1936:178).

E, como os parentes da pretendida viam com simpatia o enlace, o autor, na mesma página - como voz que paira sobre a trama -, pontificou: "E o mais triste é que bons pais de familia (...) já tenham aceitado esta situação como normal, em vez de organizarem uma liga de resistência moral que santificasse a familia em proveito da espécie”. 
A literatura que se definia como 'realista' conferia ao tuberculoso e aos seus próximos as cores da morte e da exclusão. Qualquer outra versão sobre os doentes do peito era considerada desproposital e falsa.

Por isso, quando o fimatoso Ribeiro Couto publicou, no ano de 1931, o romance Cabocla, seu texto foi alvo de inúmeras críticas, não pela qualidade da narrativa, mas sim pelo fato do autor ter tratado do encontro de dois tísicos destituídos de estigmas e que, apaixonados, encontram a ambicionada cura. Para os analistas do período, a recuperação da saúde e a felicidade não rimavam com a vida infectada.

Nas cogitações ficcionais, a figura do tuberculoso tinha se confundido com os produtos negativos da sociedade moderna, fazendo do verbo 'entisicar' um indicativo do que favorecia o nojo, a decadência espiritual e corporal e, por fim, a morte. A metáfora estava pronta para ser empregada sem qualquer reticência.

O desconhecido cronista Romeu de Avellar (1932), por exemplo, não poupou esforços para, ao avaliar tudo o que procedia de Minas Gerais, como sendo coisas e pessoas 'entisicadas', pois filhos da 'bruxa chupada' que simbolizava a 'terra tuberculosa dos mineiros'.

Contando com maior popularidade e aceitação que a medicina educadora, a literatura deixou-se entusiasmar pelo enredo tuberculoso, ganhando relativa autonomia frente ao que era ensinado pela clínica. Sob o compromisso de retratar as cenas que se repetiam nas praças públicas e atrás das portas fechadas, os escritores brasileiros deram corpo à tendência universal de estigmatizar as vítimas das doenças infectocontagiosas, isolando-as num plano em que os filhos da elite - bem mais do que os trabalhadores pobres - perdiam-se no labirinto dos prazeres, pagando os vícios prazerosos com a moeda da saúde.

Afastada dos retratos da miséria, a literatura burguesa produzida no Brasil preferiu dedicar-se às especulações sobre os efeitos da tísica dentre os representantes das classes mais abastadas da sociedade, pouco falando dos enfermos pobres e, neste encaminhamento, divergindo das apregoações clínicas.

Dissecadora da 'psicologia' do consuntivo, a literatura mostrava-se agente enriquecedor da tuberculofobia, constituindo-se em um dos mais ativos pólos discriminadores dos enfraquecidos do peito, disseminando representações negativas sobre os que tinham seus corpos e suas trajetórias sociais afetados pela tuberculose.

\section{O Objetivo Imediato: a construção do 'Homem Novo'}

A reorganização da burocracia e do aparelhamento da Higiene Pública que tomou corpo a partir da instalação do Estado Novo resultou na revitalização do Serviço de Educação e Propaganda Sanitária, sediado no antigo Distrito Federal, e na criação de órgãos congêneres e de alcance estadual, nas áreas estratégicas do país.

Situar o incremento do interesse oficial pelo ensino das regras salutares apenas como reflexo ideológico do período seria cair em esquemas simplistas de análise, que pouco contribuiriam para o entendimento da questão. Por isso, pensa-se na existência 
de um projeto médico-pedagógico que vinha sendo acalentado desde as últimas décadas da centúria anterior e que encontrou, na fase ditatorial do governo de Getúlio Vargas, condições propícias para a sua concretização, como dispositivo disciplinador e de atualização do que era então denominado como 'hábitos e comportamentos' que caracterizavam o tecido coletivo.

Entendida como tarefa necessariamente comandada por membros da academia hipocrática, a educação em saúde tornou-se instrumento privilegiado pelo Estado para conter a disseminação das enfermidades e também para afinar a vida dos cidadãos com os padrões modernos que idealisticamente deveriam reger a existência do proletariado industrial. Nesta ação, o médico travestiu-se de educador, reclamando para si o comando das tarefas orientadoras da higiene e da moralidade que deveriam promover o bemestar individual e o compromisso produtivo da vida em sociedade.

A tendência de aceitação coletiva da autoridade médica sobre o corpo social colocou a comunidade dos clínicos e dos sanitaristas como um dos principais grupos dirigentes do projeto modernizante nacional. Cumpria-se assim o sonho dos esculápios que, nas décadas anteriores, bradavam contra os erros e as mentiras pronunciadas sobre os corpos, as patologias e a moralidade e que ganhavam foro de verdades, quando pronunciadas a partir da cátedra leiga, do púlpito e dos conselhos paternos.

A premissa forjada na Alemanha e aqui insistentemente divulgada por Afranio Peixoto (1913) segundo a qual 'todo mundo é um pouco tuberculoso' conjugava-se com a ampla disseminação da Peste Branca no território nacional. Somados os fatores, a tísica serviu mais do que qualquer outra enfermidade para garantir a intervenção médica na vida pública e na esfera privada, tornando-se moléstia de referência obrigatória em qualquer aconselhamento sanitário. Neste processo, estruturou-se a medicina social brasileira que, buscando apoios na clínica, na psicologia, na sociologia e na pedagogia, cobrava aceitação inconteste ao declarar que a saúde pulmonar era resultado natural da 'prática de ações limpas' e da ‘vida sobria, temperante, moderada'.

Neste contexto, o objetivo da medicina social e educadora constituiu-se na tarefa regeneradora da população brasileira, criando condições para a efetiva capacitação do capital humano nacional. Sob o lema de 'preservar, recuperar e aumentar a capacidade do trabalhador', a Saúde Pública, atrelada ao Estado, contribuiu decisivamente para a construção do 'Homem Novo', coerente com a proposta de modernização econômica e social encaminhada por Getúlio Vargas.

Afinal, chegara a hora propícia para implantar a sociedade disciplinada pelos facultativos. "Pensai na educação, brasileiros!” era o grito heróico lançado pelo clínico e deputado constituinte Miguel Couto, no ano de 1933, pouco antes de morrer. Mas, qual seria o objetivo da educação a ser implantada? O próprio Dr. Couto deixava o direcionamento, com mote inconclusivo e nada original, emprestado dos jargões norteamericanos: “O Brasil espera que cada um cumpra o seu dever!”. 


\section{A DEFINIÇão PAUlista}

Em São Paulo, a nova orientação federal resultou inclusive na criação da Seção de Propaganda e Educação Sanitária (Spes), órgão ligado diretamente ao Departamento Estadual de Saúde. Contando exclusivamente com funcionários médicos no início de seu funcionamento, o novo setor apresentou como meta combater os principais 'flagelos sociais’ que se abatiam sobre a população bandeirante, por meio do ensino de hábitos de vida considerados saudáveis, reiterando em documento interno que: “A Educação Sanitária, difundida em todas as camadas da população, é a medida básica para a conquista e garantia da saúde coletiva, que, por sua vez, é o fator primordial da prosperidade e da riqueza do povo".

Para atingir tal objetivo, a Spes bandeirante contou com sofisticadas técnicas pedagógicas que vinham sendo desenvolvidas nos Estados Unidos e na Europa. Neste sentido, o manual de educação em saúde organizado pelos médicos norte-americanos Bauer e Hull (1937) representou o mais importante elemento incentivador dos clínicos e dos educadores paulistas, guiando a preparação do material educativo, pelo menos até o término da década de 50.

No esforço normatizador e preventivista, a Seção de Propaganda e Educação Sanitária inaugurou a produção de uma grande quantidade de folhetos, cartazes, folders e brochuras que, elaborados com um linguajar simples, de fácil entendimento e repletos de ilustrações coloridas, concorriam com os almanaques presenteados pelas indústrias farmacêuticas, abrindo uma nova fase das ações pedagógicas na área da saúde.

A garantia da distribuição gratuita dos panfletos higienistas determinou que, mesmo em outros estados, os textos da Spes ganhassem ampla divulgação, fato que obteve abrangência maior quando o governo paulista decidiu incentivar a imprensa, os canais radiofônicos e os cinemas de todo o país a reproduzir os conselhos sanitários preparados em São Paulo, visando com esta medida a atingir o maior contingente possível da população brasileira, inclusive a parcela de analfabetos.

Surgiram assim as Edições Populares da SPES de S. Paulo, denominação genérica e que incluía várias coleções de textos elaborados por ou sob a orientação da medicina social paulista. Deste conjunto de mensagens destacam-se as séries Coletânea e Romances, sendo que, até 1945, os leitores da Coletânea foram brindados com nove livros de bolso, cada um deles contando com 50 a 70 enredos curtos e tematizados pela saúde coletiva, enquanto a coleção Romances, representada por livretos de 32 páginas, editou no mesmo período pelo menos um texto que dissecava personagens tuberculosos.

No final, ambas as séries ganharam grande divulgação popular, inclusive porque foram bem aceitas pelos diretores dos meios de comunicação que, por volta de 1942, reproduziam regularmente os alertas sanitários nas páginas de 363 jornais e 22 revistas, assim como os veiculava por intermédio de 16 emissoras de rádio, sob formato novelístico. 
A análise desse núcleo documental impõe como tarefa inicial a necessidade de identificação dos personagens aproximados pelas mensagens higienistas. Isto porque, apesar do discurso sanitário se apresentar universal e dirigido para todos os estratos sociais, na verdade foi dimensionado para servir como peça de convencimento de grupos específicos da sociedade, identificados não só pela posição que ocupavam no corpo coletivo, mas também por circularem em ambientes geográficos particulares.

A obediência a esta fórmula determinou que a orientação preventivista direcionasse seus ensinamentos para os moradores do espaço metropolitano, ou melhor, para a "babel urbana", onde homens provenientes de várias partes do país e do globo confluíam em busca de novas oportunidades de vida. Nesta trajetória, a clínica educadora advertia que a cidade se apoderava dos homens, ditando o 'ritmo alucinante' da existência grupal e individual. Em continuidade, o território urbano foi visto como a pátria do egoísmo e da perdição, onde o ‘vício depravado' e a ‘corrupção dos costumes' comprometiam a regularidade da vida e os 'altos ideais coletivos', resultando no 'contínuo desgaste das energias vitais'.

O resultado de tudo isso não poderia ser outro: "Em geral, o aspecto de um cidadão com seus 40 anos é bom, porem dentro do seu arcabouço ósseo-muscular trabalha o germe da destruição precoce, que pode levá-lo à tumba muito antes do que deveria ser" (Coletânea 6, 1942:118).

Nesta operação, o eugenismo médico chamou para si a tarefa de 'recuperação da raça', utilizando a intervenção educativa para instruir as coletividades urbanas sobre o código saudável que fora acoplado à concepção de 'vida moderna'. Erigia-se assim a imagem do locutor das mensagens sanitárias como a voz clínico-epidemiológica e moralista que, escudada na razão da ciência positivista e na ética cristã, variava o tom entre o conselho amigo e a imposição autoritária, exigindo sempre o silencioso acatamento das idéias que veiculava.

Todos aqueles que se contrapunham à obediência coletiva ganhavam o epíteto de 'traidor' da causa comum, sendo enquadrados nesta categoria não só os que se negavam a cumprir as considerações protetoras da própria saúde, mas também aqueles que, por desleixo ou por ganância, induziam outras pessoas ao erro, destacando-se nesta condição os pais despreocupados com a higiene física e moral de seus rebentos e especialmente os farmacêuticos que usurpavam a exclusividade médica para clinicar e se desfazer de seus estoques terapêuticos encalhados.

Na seqüência, seria ingênuo supor que os enunciados educativos visassem a atingir a população urbana como um todo. A proposta de capacitação para a vida moderna situava o proletariado com raízes fincadas no solo metropolitano e os grupos pobres e com escassa experiência citadina como setores privilegiados do norteamento higienista.

O médico Octavio Gonzaga (1941), ex-diretor do Serviço Sanitário paulista e um dos principais expoentes da burocracia da saúde durante o período varguista, talvez tenha sido o personagem que melhor definiu o método e o objetivo da prática pedagógica que imperou durante o Estado Novo. Para ele, a educação higienista deveria ter como base um ‘discurso positivo' que, evitando a abordagem aprofundada das noções clínicas, se concretizasse como mensagem de pronto entendimento para o público-alvo das campanhas de saúde, representado unicamente pelas 'classes trabalhadoras'. 
O direcionamento das ações educadoras para a população proletária tinha explicação: era o operariado fabril e os empregados do setor de serviços que mostravam maior fragilidade em relação à ‘sede de ouro’, condenando estes grupos à perene rebeldia contra a 'pobreza honesta', marca que os coagia a trocar o vigor físico e a honra por qualquer aceno de dinheiro, poder e prazeres fáceis.

Segundo o Dr. Gonzaga, os trabalhadores diferenciavam-se da elite endinheirada por colocar tudo de lado para satisfazer a ânsia de riqueza, inclusive os fundamentos morais que dão conformidade à vida social e os princípios higiênicos que garantem a saúde individual e a produtividade coletiva. Para reforçar este posicionamento, o exdiretor do Serviço Sanitário invocou a trajetória de vida dos filhos da pobreza que sacrificaram a saúde e a moral para alcançar fortuna e prestígio. Nesta tarefa, o médico preferiu afastar-se dos paradigmas nacionais, citando como exemplos os 'modernos ditadores da Europa’, implicitamente referindo-se às biografias de Hitler e Mussolini, personagens que, sintomaticamente, haviam sido diagnosticados como 'fracos do peito’ nos anos de adolescência.

Para evitar que o Brasil gerasse 'monstros' iguais aos que estavam colocando fogo na modelar Europa, a medicina social prescreveu uma série de reparos no que inicialmente foi denominado de 'alma popular'. Mas, segundo os intelectuais orgânicos do Estado Novo, qual seria a essência deste espírito coletivo? A resposta talvez possa ser encontrada em um dos artigos de abertura do primeiro volume da Coletânea, em que um autor anônimo pontificou que as marcas centrais do ‘trabalhador brasileiro' constituíam-se na postura individualista e na rebeldia frente aos dispositivos legais que davam forma à nação, já que a população urbana tinha sido moldada pelo 'sentimento liberal, que é a linha mestra da sua consciência’.

A substituição do termo ‘alma popular’ pela categoria ‘nacionalidade’ dominou as peças educadoras, exigindo que os médicos colhessem inspiração nos modelos estrangeiros para aconselhar uma profunda reforma dos comportamentos sociais. Por isso, durante o período em que Getúlio Vargas mostrou-se reticente em apoiar um dos blocos envolvidos na Segunda Guerra Mundial - situação que foi explicada pelos higienistas como sábia decisão presidencial para não criar tensão emocional na sociedade e favorecer o enfermamento coletivo - a comunidade hipocrática brasileira, sempre cautelosa, apregoou o estilo de vida vigente na neutra Noruega como o padrão que deveria ser reproduzido por todos os brasileiros.

Apesar da surpresa causada pela opção, a idéia foi prontamente incorporada pelos educadores sanitários paulistas, resultando na multiplicação de textos que apontavam para o exemplo escandinavo como antídoto recuperador do degradado caráter urbano brasileiro. Em nome da preservação da ordem e da saúde pública, assim foi apresentado o ‘reino do equilíbrio':

A Noruega é o País da Cocanha dos nossos tempos. Real, vivo, feliz. (...) Cada um tem o seu lugar. (...) Por isso a vida desliza numa planície. E não é sacudida pelo entrechoque das ambições pessoais desmedidas. Tudo é ajustado. (...) O Homem norueguês é calmo, controlado, mesmo nos gestos, no olhar, na palavra. Detesta a violência. Tem horror às cenas. Aos dramas expostos. Tudo que 
venha a ferir a harmonia ambiente ecôa forte como escândalo. Que o norueguês abomina. Há na sociedade norueguesa um admirável meio têrmo. Um equilíbrio inalterável. Que é a civilização. (Coletânea 1, 1939:67).

Entretanto, após a entrada do Brasil no conflito mundial, os conselhos educadores experimentaram sensíveis revisões. Em coerência com o novo alinhamento político da nação, o modelo norueguês foi preterido em favor da agitação e da operosidade yankee.

Nas páginas da Coletânea, os 'irmãos do norte' ganharam destaque, inclusive por meio de artigos assinados por norte-americanos que, em uníssono, convergiam para elogio do american way of life. O vestuário e o calçado, a alimentação e as regras sociais, o amor ao trabalho e a fidelidade ao presidente da República e à Constituição nacional, o bônus de guerra e a organização sanitária, tudo foi examinado como moderno, funcional e saudável porque forjado nos Estados Unidos.

Ademais, os higienistas brasileiros ansiavam em ver reproduzido no Brasil o mesmo juramento solene que se dizia firmar nos lares de todos trabalhadores norteamericanos, apresentado pelo vice-presidente norte-americano Henry Wallace: "Comprometo-me, pela minha honra de americano, a fazer todo o possível para que eu, minha família e os que me cercam nos tornemos cada vez mais robustos e saudáveis, como Deus sempre quis que o sejamos”(Coletânea 7, 1942:61).

Neste contexto, a tuberculose como principal flagelo sanitário que se abatia sobre a população tornou-se o tema mais invocado nos textos produzidos pelo setor educativo do Departamento de Saúde de São Paulo. Os perigos e os efeitos desastrosos da Peste Branca inspiraram a matéria presente em centenas de conselhos, constituindo-se, assim, em recurso básico da medicina social para a comunicação com as 'classes trabalhadoras'. Em nome da tísica, buscava-se orientar os contingentes pobres, em conformidade com os princípios da vida moderna, equilibrada, saudável, honesta, enfim, de utilidade produtiva para a nação.

O fundamento norteador do discurso em saúde era a asserção que definia a tuberculose como uma patologia cujo diagnóstico, prognóstico e terapêutica eram minuciosamente conhecidos pela clínica que, nesta condição, dispunha de recursos eficazes para assistir e recuperar a saúde de qualquer infectado. A dimensão curável imposta à enfermidade estabelecia que 'só é doente quem quer', atribuindo-se inteira responsabilidade aos (des)caminhos da existência individual como fator desencadeante da infecção kochiana.

Assim, o tísico era qualificado, em conformidade com as posturas que proliferavam especialmente nos Estados Unidos, como um personagem egoísta que deixouse contaminar porque se manteve cego frente aos interesses coletivos, transformando-se duplamente em pária da sociedade, já que, além de se tornar improdutivo, exigia ser sustentado pela caridade pública.

No encaminhamento do processo pedagógico, os avisos sanitários buscavam abranger as diferentes faixas etárias, cobrindo integralmente os membros das famílias trabalhadoras. Estabelecendo o consuntivo como objeto passivo de intervenção, os médicos e os educadores empenharam-se no convencimento dos adultos como possíveis vítimas do mortal contágio e também como responsáveis pelas crianças que poderiam ser infectadas pelo micróbio da tísica. 
Aos adultos, os sanitaristas apresentavam a Peste Branca como patologia ainda mais tenebrosa que a hanseníase. Isto porque, ensinava-se, enquanto os leprosos podiam ser facilmente identificados e subtraídos do convívio comum, o mesmo não acontecia com os tuberculosos que, protegidos pelos discretos sinais produzidos nas primeiras etapas da enfermidade, permaneciam em contato com os sadios, poluindo o ambiente e espalhando propositalmente as sementes da morte.

Considerado como a 'hidra de mil cabeças', o Grande Mal foi declarado inimigo maior do tecido social. Exigia-se, assim, de cada indivíduo o compromisso 'moral e cívico’ de preservar a própria saúde como tributo ao Estado e aos interesses coletivos. A partir do apregoamento de um estilo ‘equilibrado' de vida, a medicina cobrava dos moradores da urbe 'idéias sadias', devendo cada um afastar-se o máximo possível das 'festas desnecessárias', das 'más companhias' e inclusive do casamento com 'pessoas duvidosas' que inexoravelmente resultavam na perpetuação do exército de 'viciados’ e 'degradados' que atentavam contra a existência e o poderio nacional.

A vida comedida e os hábitos e ideais salutares tinham como contraponto educativo a condição existencial dos tísicos, muitas vezes caricaturada por meio de referências biográficas dos personagens da história e da literatura romântica. Longe das análises exaltadoras que vigiam em épocas anteriores, os sanitaristas preconizavam os tipos cultuados no século XIX como doentes dos pulmões que 'tombaram no verdor dos anos' em conseqüência dos erros higiênicos cometidos contra o próprio organismo e também contra o ambiente em que viviam. Neste encaminhamento, o médico Américo Netto concluiu que: "Os boêmios românticos foram assim criaturas predestinadas para todo cortejo de extravagância que, com as vicissitudes da fome, levou muitos deles ao túmulo" (Coletânea 8, 1942:101).

Advertia-se também que o principal foco de contágio constituía-se nos próprios indivíduos com os pulmões corrompidos. Mais do que a poeira das casas e das ruas e o leite e as carnes contaminadas, o tísico era denunciado como o agente central da disseminação consuntiva, aconselhando-se a todos guardarem cautelosa distância dos estranhos, pois eles bem poderiam ser os emissários da peste. Nesse sentido, mereciam desconfiança não só os magros que escarravam sangue, mas também o 'tipo florido' versão educativa do 'aparentemente sadio' - que, gordo e ágil, poderia ocultar em sua aparência enganosa o 'germe maldito'.

Reforçando ainda mais o horror à aproximação com os pectários, as mensagens médicas empenhavam-se em exacerbar os medos coletivos por meio da divulgação de tétricas descrições, nas quais o reino da tuberculose se expandia como resultado da negligência alimentada pelos sadios. Muitas páginas da Coletânea foram dedicadas para a minuciosa narração de casos em que a tísica fazia mais e mais súditos, identificando o ambiente da infecção com o espaço e as práticas urbanas.

Assim, o mortal contágio poderia ocorrer tanto no interior de um bonde ou de uma repartição pública, onde as pessoas forçosamente eram obrigadas a permanecer muito próximas umas das outras, quanto na solidão de uma biblioteca, pois, se o volume consultado tivesse sido anteriormente manuseado por um fimatoso, havia boas chances para que o incauto leitor fosse assaltado pelo bacilo de Koch. 
A desconfiança e a vigilância recíproca deveriam ser ainda mais intensivas quando a saúde das crianças estivesse em risco iminente. Definida como 'o Homem de amanhã' pelos cartazes que a Spes paulista fazia afixar nas salas de espera de todos os Centros de Saúde do estado, alertava-se a população e os pais que 'protegê-la é nosso dever'.

As mensagens sanitárias, portanto, ganharam maior intensidade ao tratar das possibilidades do contágio infantil, orientando os adultos para exigir a apresentação de Carteira de Saúde de todas as pessoas que mantivessem contato diário com crianças, incluindo professores, empregados domésticos e especialmente as mulheres que serviam como amas-de-leite. Mesmo situações embaraçosas para a harmonia familiar deveriam ser enfrentadas sem receio, quando a saúde infantil estivesse em jogo: caso existisse um tio que denunciasse uma 'tossezinha nicotínica', dever-se-ia proibir-lhe o acesso aos pequenos, assim como o 'danoso hábito' do beijar ou dormir no mesmo quarto que acomodava os petizes.

A puberdade constituía-se em momento da existência em que eram ampliadas as chances do indivíduo ser assaltado pelo micróbio fimatoso. As alterações físicas próprias desta fase do desenvolvimento orgânico somavam-se ao dispêndio de energia cobrado pelos estudos e pelo início da faina produtiva, debilitando o corpo e tornandoo presa fácil da tuberculose.

Na continuidade das observações, os higienistas pregavam que, bem mais do que estas condicionantes, os novos 'hábitos' assumidos pelos adolescentes predispunham à moléstia consuntiva, incluindo neste processo o namoro e o comparecimento diário aos bailes, teatros, bares e cassinos. Encantados com os prazeres da vida, os jovens desarmavam-se das defesas físicas e morais, entregando-se passivamente ao avanço destruidor da moléstia pulmonar, cabendo por isto à educação em saúde dedicar-se com especial empenho no regramento desta parcela imprudente da população.

\section{Romance da Tísica}

As imagens sobre a doença e o doente do peito frutificaram também na coleção Romances elaborada pela Seção de Propaganda e Educação Sanitária paulista. Ao contrário das outras séries, onde os médicos higienistas praticamente monopolizavam a produção discursiva, as ‘obras ficcionais’ publicadas pelo Departamento de Saúde contavam com a habilidade literária de vários escritores profissionais e de larga aceitação pública, encontrando-se dentre eles Afonso Schmidt, Orígenes Lessa e Galeão Coutinho.

Avizinhados da prosa naturalista do século XIX, os 'romances' educativos utilizavam como principal recurso de composição o confronto entre dois personagens, sendo que cada um deles incorporava uma opção moral e um horizonte de vida. Esta estratégia permitia a comparação entre ‘hábitos e comportamentos' antagônicos, tornando facilmente inteligível a premissa que denunciava as enfermidades como resultado inevitável da vida desregrada. 
Apesar de várias peças literárias patrocinadas pela Spes dissecarem a trajetória e os sentimentos de personagens secundários que provavelmente estivessem com os pulmões corroídos, o texto assinado por Afonso Schmidt (c. 1944) intitulado O Gigante Invisivel ganha destaque por se constituir numa obra toda centrada em torno da Peste Branca e seus tributários. O livreto impressiona não só pelo direcionamento imposto à trama, mas também pelas ilustrações desenhadas por Paulo Camiller Florençano.

Diferentemente dos demais volumes da coleção, a capa da peça em questão chama a atenção pelo colorido vermelho forte utilizado em sua composição, opção que ao mesmo tempo lembra a tonalidade sangüínea e o sinal de alerta. O desenho da folha de rosto do 'romance' retrata um homem de costas, sugerindo alguma coisa entre o abatimento físico e a displicência frente ao perigo que ronda, sendo este representado por uma mão descomunal com unhas afiadas, oferecendo a dimensão da ameaça que a qualquer instante se apoderará do incauto, roubando-lhe a saúde e a vida.

A ilustração de abertura ganha desdobramento no texto dedicado à descrição da trajetória de Carlos, um migrante que chega à 'capital' (que bem pode ser a cidade de São Paulo, informação que nunca é confirmada) ‘esbanjando saúde’ e que imediatamente encontra colocação em um escritório de contabilidade. O fascínio pela agitação metropolitana e a condição de solteiro e sem qualquer compromisso familiar induzem o recém-chegado a obedecer um comportamento desleixado, aceitando abrigo no quarto de uma fétida pensão, onde a qualidade da comida e da higiene em nada garantiam o bem-estar dos hóspedes.

Os cenários de trânsito do migrante desdobram-se no ambiente de trabalho, onde Carlos é identificado inicialmente como 'bom trabalhador' e ‘solícito companheiro’ pelos demais escriturários. Em pouco tempo, porém, profundas transformações começaram a ocorrer nas atitudes do novato que, deixando-se seduzir pelas 'más companhias' que conheceu nos bares, passou a se alimentar irregularmente, preferindo "enganar o estomago com pasteis e pinga" e gastar as horas noturnas em desatinadas conversas nas esquinas, sempre terminando a madrugada na 'farra'. Optando por este ritmo de vida, Carlos voltava as costas para a sombria realidade:

a tuberculose é a doença da miséria. Nas nossas grandes cidades, como Rio de Janeiro, São Paulo, Porto Alegre e Salvador, a sua multiplicação é rápida, acompanha o pulsar de um relógio. Há, não se sabe onde, um gigante de clava em punho, que não se cansa de desferir golpes sôbre golpes... Tic, tac, tic, tac... Mais um, mais um, mais um, mais um... Esse gigante feroz é invisivel... Chamase Dom Bacilo... (Schmidt, c.1944:21-22)

A ausência de repouso e de alimentação adequada conjugava-se com a bebida alcoólica e as companhias comprometedoras, levando o migrante a uma situação única: a fraqueza física. Desdenhando dos nítidos sinais da degradação corporal, Carlos manteve-se convicto freqüentador das noites, fato que contribuiu ainda mais para exponenciar os desarranjos que consumiam o corpo, resultando inclusive em contínua irritação e incapacidade para o trabalho cotidiano.

Foi neste contexto de perdição individual que Afonso Schmidt colocou em cena César que, apesar de guardar semelhanças biográficas com Carlos, foi apresentado 
como a imagem oposta do forasteiro que se deixou impregnar pelos desvarios da 'cidade grande’. Migrante e destituído de laços familiares, mesmo assim César mantinha uma existência 'casta' e 'equilibrada' e, na condição de 'guia dos perdidos', interessou-se pelo destino do parceiro de escritório, advertindo-o sobre os mortais perigos representados pelos prazeres vendidos nas madrugadas e que pouco a pouco levavam os desajuizados para o túmulo.

Inicialmente, o 'rapaz perdido' desdenhou dos conselhos oferecidos pelo amigo, mas, na continuidade do 'enfraquecimento físico', Carlos viu-se preso ao leito da pensão, sem forças até mesmo para caminhar até o escritório onde trabalhava. A ausência do funcionário rebelde chamou a atenção de César que, ao visitar o enfermo, percebeu de imediato a presença do 'Gigante Invisível'.

Com a ajuda do amigo, o tuberculoso passou por um verdadeiro processo de conversão moral, abjurando da antiga 'vida de estróina', fato que o levou a freqüentar o gabinete de um médico que, além de lhe ensinar as regras básicas de higiene, informou que a tísica constituía-se em ‘doença curável', cuja evolução dependia dos ‘sacrifícios' aos quais o paciente consentisse submeter-se.

A convicção de que o restabelecimento da saúde pulmonar dependia da imediata mudança de ares levou Carlos a buscar residência em uma localidade pouco afastada do burburinho urbano, apresentada como região de qualidades climatoterapêuticas e própria para o repouso prolongado. Amparado pelos donativos feitos mensalmente pelos seus colegas de escritório, o tuberculoso foi gradualmente recuperando a antiga disposição física, fazendo então um juramento ao tisiologista encarregado de seu tratamento:

- Muito obrigado, doutor. Quando eu voltar à cidade e ao trabalho, procurarei fazer pelos outros o que César fêz por mim. Direi a muita gente: cuidado, seus bobos, vigiem constantemente a saúde, não se esqueçam do que ia acontecendo ao Carlos... (Schmidt, c.1944:32)

Pelo menos na literatura, o trabalhador brasileiro fez um juramento muito aproximado àquele preconizado pelo vice-presidente dos Estados Unidos.

Pergunta-se: por que a Peste Branca, apesar do empenho médico e governamental anunciado, não cessava de expandir seu reinado na 'Chicago sul-americana'? Se a explicação maior era localizada no 'caráter reacionário das classes produtivas' em acatar o norteamento médico, a vertente populista inaugurada por Getúlio Vargas inspirou os agentes educativos a detectarem na apatia do grupo dirigente da indústria e do comércio paulista um fator coadjuvante na escalada da tísica.

As mensagens articuladas pela Spes paulista, em alguns momentos, definiram os 'capitalistas' como um grupo que, igualmente ao proletariado, carecia de formação moral e sanitária coerente com os princípios norteadores do Estado Novo. Em continuidade, rogava-se que a elite dirigente esbanjasse menos dinheiro na aquisição de 'caríssimos automóveis' e 'finíssimos vestidos elegantes' e repartisse com o Estado o ônus representado tanto pela assistência aos pectários quanto pela construção de sanatórios. Além disso, a classe patronal foi colocada no banco dos réus por contratar funcionários sem a exigência de apresentação da Carteira de Saúde e, ainda, afastar-se da orientação paternalista consagrada pelo presidente Vargas. 
Foi com um certo olhar nostálgico que um sanitarista anônimo apresentou em um dos volumes da Coletânea um texto que diagnosticou a principal lacuna aberta no relacionamento ‘moderno’ entre os capitães da indústria e seus subordinados:

É o caso do patrão generoso que não quer intervir na vida privada do seu empregado de escritório, e o vê chegar sonolento ao trabalho, depois de uma noitada de dansa ou de bebedeira. Quantos aborrecimentos e quantas lástimas não seriam evitados se nesse momento viesse o conselho ou a reprimenda, dados por quem tem força moral para fazê-lo? (Coletânea 1, 1939:48)

Seguindo este encaminhamento, uma vez mais a administração sanitária paulista se colocou à frente da Saúde Pública Federal que, menos produtiva, mostrou-se reticente em assumir um discurso pedagógico abrangente. Os educadores sanitários de São Paulo, por sua vez, buscaram dar sentido universal às mensagens preventivistas, recorrendo a um código informativo que, evitando declarar-se tipicamente paulista, mesmo assim contextualizava a problemática específica da região.

A composição de um discurso cujo locutor postava-se como agente cosmopolita e moderno enfatizava, em gênero, as condições de vida das metrópoles - quaisquer que fossem elas - pontificando a positividade dos valores e condutas que confluíam para a disciplinarização do ‘capital humano’ nacional. A atualização dos corpos e das mentes favoreceria, a um só tempo, a produção e o consumo de mercadorias, dando direcionamento apregoado como 'racional' aos comportamentos que, afinal, deveriam consolidar os mecanismos regentes da formação social brasileira.

\section{Uma Outra Educação: os tuberculosos 'ricos'}

Apesar da ampla divulgação das recomendações educadoras em saúde produzidas pela Seção de Propaganda e Educação Sanitária de São Paulo, é provável que as camadas médias instaladas no espaço metropolitano vissem com certa reticência os 'conselhos médicos' direcionados ao proletariado. Afinal, para os grupos que se autoapresentavam como agentes privilegiados do movimento de modernização econômica e social, pareciam aviltantes as prescrições formuladas pela Spes que, dentre outras coisas, tentavam convencer seus leitores sobre a necessidade de aceitar a 'pobreza honesta', evitar que os filhos dormissem na mesma cama que os pais e manter a residência limpa e arejada.

Portanto, quando as campanhas oficiais de educação em saúde foram implementadas, também ganharam consistência os reclamos da 'elite culta', pedindo o patrocínio governamental para a maior divulgação de livros que ensinassem as precauções a serem tomadas contra a tuberculose e que também discorressem sobre as possibilidades de cura dos pectários. Sob o discreto rótulo de 'divulgação scientifica', os agrupamentos privilegiados ansiavam por melhor conhecimento sobre a Peste Branca, talvez mesmo para saber reconhecer os infectados e excluí-los de seu círculo de convívio. 
As oportunidades de encontros com os médicos delineavam-se como momentos privilegiados para a elite se informar sobre os processos patológicos. Nos consultórios particulares, a burguesia queria saber mais, inclusive sobre tópicos que nem sempre era de bom tom perguntar ao médico. No início da década de 40, a Educação Sanitária federal, melhor que a paulista, soube perceber as reticências dos grupos ensimesmados dirigindo-lhes uma coleção de textos que, guardando proximidade com as resenhas acadêmicas, ofereciam aos leitores a sensação de que estavam consultando mensagens exclusivas e, por óbvio, diferenciadas em teor aos conselhos direcionados ao proletariado.

O sentimento de abandono experimentado pelos estratos mais ricos da população explica, pelo menos em parte, o surgimento de publicações sintonizadas com a sensibilidade burguesa, como o paulistano mensário Viver!, definido como revista especializada em 'saúde, fôrça e beleza'. Colecionando artigos assinados tanto por médicos quanto por jornalistas, o periódico procurava corresponder aos anseios dos seus assinantes, discorrendo longamente sobre a tuberculose, sem, no entanto, incorporar os padrões obedecidos pelos órgãos oficiais dirigidos para a educação sanitária.

Paralelamente, Viver! empenhava-se em fomentar a apologia do modelo sociocultural norte-americano, preterindo as condições de vida do trabalhador brasileiro em favor da descrição meticulosa e ufanista do vigor físico e dos hábitos saudáveis dos astros do cinema, forjados em Hollywood. ${ }^{1}$

Além das revistas especializadas em discorrer sobre a saúde no contexto da modernidade, a elite nacional passou a dispor de um conjunto de livros que se apresentavam como 'manuais' de orientação aos tuberculosos e a todos aqueles dispostos a se inteirar sobre os segredos da Peste Branca.

No Brasil, a tentativa pioneira de elaboração de um guia sobre a tísica data dos anos iniciais do século passado, quando o médico Eloy de Andrade (1906) publicou o primeiro texto apresentado como 'obra de divulgação científica' sobre a moléstia dos pulmões. A persistente defesa da concepção segundo a qual a tísica era "perfeitamente curavel” e os inúmeros casos escabrosos mencionados nas páginas do manual - inclusive detalhada descrição do comportamento sexual de "vacas ninfomaníacas", porque tuberculosas -, parece ter desencorajado a recomendação clínica deste compêndio.

Na ausência de livros orientadores produzidos no Brasil, é provável que a única opção disponível para a elite leiga saber mais sobre a tuberculose constituía-se na recorrência aos alfarrábios estrangeiros. Vários textos redigidos em francês, inglês, italiano e alemão voltados para a orientação dos tuberculosos e de seus familiares foram mencionados em artigos educativos de clínicos brasileiros, sendo que, dentre estes, nenhum outro manual angariou tanto reconhecimento como o elaborado pelo professor da Escola Médica da Universidade de Genebra, Jacques Stéphani.

Proprietário e diretor clínico da estação climatérica e do sanatório de Montana, nos Alpes suíços, o Dr. Stéphani acolheu inúmeros esculápios brasileiros que buscaram especialização tisiológica na Europa e, em 1929, publicou o seu guia para 'tuberculosos e predispostos'. Em pouco tempo, a obra tornou-se o texto mais recomendado pelos clínicos brasileiros, que passaram a indicá-la - ainda na versão francesa - tanto aos "medicos não especialistas" quanto às "pessôas cultas que amam estar ao corrente de conhecimentos gerais” (Pitanga, 1933). 
O livro do professor Stéphani foi publicado em língua portuguesa no ano de 1933, contando com a tradução do escritor Ribeiro Couto que, pectário, rumou para a Suíça, obtendo a cura no sanatório de Montana. No prefácio brasileiro deste guia, o tradutor confessou que a versão nacional do livro do Dr. Stéphani era bem mais do que um trabalho encomendado pela editora, consistindo em tributo de um ex-paciente ao clínico que o salvou da morte certa. Ribeiro Couto acrescentou ainda que o manual representava um indispensável instrumento para os contaminados e os sadios se conscientizarem sobre a desabonadora valoração social da enfermidade, definida como "enorme trama de preconceitos absurdos, da ignorancia e de erros de que, no espirito do vulgo, anda acompanhada esta palavra: tuberculose” (Stéphani, 1933:6).

A partir de então, o livro do tisiologista suíço passou a ser aclamado como o principal recurso esclarecedor sobre a tísica à disposição da parcela culta da população. A aceitação da obra - que contou com sucessivas reedições nos anos subseqüentes ao seu lançamento - incentivou inúmeros clínicos proprietários de sanatórios a comporem obras similares. No entanto, praticamente todos os guias nacionais acomodaram-se em repetir os ensinamentos do manual do Dr. Stéphani, às vezes incorrendo no plágio da obra do médico suíço.

O que ensinava o professor Stéphani para que seu livro fizesse tanto sucesso, a ponto de, no Brasil, contar com edições de luxo e ser alvo de tantas imitações?

Primeiramente, a aceitação deste texto está ligada ao reconhecimento clínico da precariedade do saber acumulado pela medicina sobre o evento patológico. Avesso às 'certezas' procuradas pelos seus pares, o Dr. Stéphani confessou para os 'profanos' as 'incertezas' que atormentavam a prática tisiológica, tachando de charlatães todos aqueles que asseveravam ser o mal consuntivo uma enfermidade 'perfeitamente curável'. Nesta cirurgia, o clínico de Montana despendeu páginas e mais páginas para recuperar a historicidade das práticas médicas e das imagens creditadas aos infectados para anunciar o caráter provisório do aparelhamento clínico-epidemiológico e o condicionamento cultural dos preconceitos contra os tísicos.

O professor de Genebra descreveu em detalhes o funcionamento do corpo humano sadio, para didaticamente apresentar a noção do trabalho destrutivo do bacilo de Koch, advertindo que "a tuberculose teme o bisturi". Neste encaminhamento das idéias, o arsenal medicamentoso disponível na época foi considerado de pouca valia no tratamento dos seus pacientes, alegando que a única terapêutica cuja eficácia foi constatada, mesmo sem explicações totalmente convincentes, consistia na reclusão dos contaminados por longos períodos nas regiões de altitude, ensinando que "mais vale o campo que a cidade, mais vale a montanha que o campo".

Proprietário de uma estação alpina de tratamento, o médico caminhou para a defesa da idéia segundo a qual apenas a presença dos consuntivos nas regiões montanhosas não garantiria minimamente a recuperação da saúde. Para o Dr. Stéphani, as benesses do 'clima de altitude' deveriam estar conjugadas à disciplina exigida no ambiente hospitalar, pois a melhora do estado de saúde só poderia ser conseguida por meio da articulação da climatoterapia com a reeducação higiênica e moral dos fimatosos.

O que significava para o autor do Guia do Tuberculoso e do Predisposto a reeducação do consuntivo? Apesar da referência aos exageros do sexo, do álcool e da 
droga como eventos predisponentes à infecção, para o docente suíço, tais elementos constituíam-se em itens de menor significado para a ocorrência da tísica. Bem mais do que a correção moral, cabia ao médico de sanatório ensinar seus pacientes a manter um novo vínculo com o próprio corpo, instruindo a clientela sobre a necessidade de uma relação equilibrada com o organismo, enquadrando este como uma realidade pautada por múltiplos condicionantes, tais como a resistência biológica individual, a alimentação, a idade, o sexo e as condições materiais de vida.

Nesta operação, o Dr. Stéphani baseou todos os seus conselhos no sutil retoque do modo de vida burguês que, se moderno, deveria ter como elemento norteador o desfrute comedido das novidades trazidas pela sociedade industrial do século XX. Por isso, a própria qualificação do infectado ganhou novas dimensões.

A condição tuberculosa foi despida dos atributos degradantes impostos por outras vertentes de avaliação hipocrática, aflorando como 'doente perigoso' exclusivamente aquele que "não cospe numa escarradeira, que atira perdigotos ao se agarrar no interlocutor, que beija toda gente apezar de saber que tem bacillos na bocca” (Stéphani, 1933:76). Ninguém mais. Discursando para o paciente tuberculoso bem mais do que sobre o doente pulmonar, o médico tornou-se uma espécie de amigo solidário e 'redentor' dos pectários, inaugurando uma nova conduta de comunicação impressa entre a clínica e os doentes do peito.

Despojado da maligna aura, o tuberculoso - ainda segundo o médico suíço deveria buscar isolamento em uma estação de cura, não como um castigo mas sim como uma situação transitória e benéfica para si e para os seus familiares. Afinal, o sanatório correspondia a uma variação sofisticada de 'hotel de luxo', onde a higiene e as possibilidades de aprimoramento cultural eram ponto de honra, acrescentando Ribeiro Couto, em nota de rodapé, que o próprio Dr. Stéphani dominava variados idiomas, dispondo-se a ensinar a todos os doentes 'contagiados pelo entusiasmo cultural do mestre'.

Neste encaminhamento, o autor do guia reivindicava o relacionamento 'sadio e franco' com os seus pacientes/discípulos, cobrando deles estrita lealdade às suas orientações. Nenhum de seus 'hóspedes' poderia se mostrar mais conhecedor dos segredos da enfermidade que o próprio facultativo e a confiança mútua deveria ser tamanha, que nenhum outro clínico poderia ser consultado, sob a pena de exclusão do infectado do recinto sanatorial. A sujeição do tísico deveria ser total, assumindo como suas as prescrições fornecidas pelo tisiologista:

Quanto à cura, não pode ser obtida, na mór parte dos casos, senão associandose, num commum esforço, a sciencia do medico à boa vontade do enfermo. Mas, aqui, attenção! Nada de malentendidos. O que o medico pede ao doente é um esforço continuo de todo o seu ser para um só objectivo, sempre o mesmo. Não se trata de collaboração, mas antes de hierarchia: um manda, outro obedece. (Stéphani, 1933:186)

Mesmo assim, em diversas passagens do seu manual, o proprietário da estação de cura alpina buscou amenizar a rigidez da normatização clínica, embora ressaltasse que o médico convicto da eficácia de seus conhecimentos não deveria se curvar frente aos desejos do paciente. 
No sanatório de Montana - advertia o Dr. Stéphani - tudo era passível de ser matéria de diálogo e moderação, podendo chegar-se a acordos que não resultassem em perdas para o médico ou para o paciente. Os exemplos são significativos: o tenista inconformado com a proibição de praticar seu esporte reclamou da prescrição, conseguindo autorização médica para continuar a jogar diariamente, sob a condição de interromper a partida ao final do quinto game, assim como ao nobre russo foi permitida a utilização paralela de poções curativas tradicionais no seu país, já que estas não afetavam o tratamento ministrado pelo nosocômio.

Pouco, de original, os médicos-autores brasileiros acrescentaram aos enunciados do Dr. Stéphani. A consulta de mais de duas dezenas de manuais para tuberculosos compostos por clínicos brasileiros até o ano de 1945 deixa perceber a contínua reiteração dos mesmos postulados e a menção até dos mesmos exemplos registrados no guia estrangeiro, consagraram as propostas do especialista suíço como regras pouco infringidas pelos autores das brochuras nacionais.

Uma das raríssimas páginas na qual este cômodo compromisso foi quebrado encontra-se no livro do Dr. Valois Souto (1937), diretor-proprietário do Sanatório de Corrêas, instalado nas montanhas fluminenses e que era considerado uma das mais luxuosas casas de saúde do país. Ao indagar sobre a possibilidade do tuberculoso com lesões abertas querer contrair matrimônio, Valois Souto mostrou-se totalmente contrário. Entretanto, imediatamente após a negativa, o autor parece que arrependeu-se, alegando que, afinal, a opinião médica não era assim tão importante, desculpando-se envergonhadamente por se imiscuir na vida privada dos seus pacientes abonados: “mas que fazer quando só se têm em vista razões do coração!...”.

Em nome do Grande Mal foram articulados múltiplos dispositivos disciplinadores, direcionados para grupos específicos da população, infectados ou não. Idealizados como discursos universais e fundamentados em valores que buscavam transcender as diferenças sociais, como solidariedade, família, bem comum, pátria e trabalho, na verdade as orientações higienistas mesclavam tisiofobia e diferenças de classe, resultando na sensação de que a educação sanitária discorria sobre distintas patologias, mais do que sobre tuberculosos ricos e tuberculosos pobres.

No final, o discurso sobre tísica erigiu-se como estratégia de coerção que, direcionada para a ‘retificação’ dos comportamentos individuais, buscava requalificar a vida grupal, estabelecendo os padrões da modernidade que deveriam reger a organização social brasileira. Ficavam claros, assim, os limites das pontificações educadoras em saúde que, calcadas na exploração dos temores grupais, identificaram os fracos do peito como discípulos do mal e da desordem coletiva, traduzindo o tuberculoso como o pobre irrequieto, o rico egoísta, o perverso, o criminoso, o inimigo da pátria, o ‘quintacoluna' e tantas outras categorias.

Nesta cirurgia, o ramo educador da Saúde Pública paulista, acompanhando a tendência predominante na literatura nacional das primeiras décadas do século, contribuiu com novas e vigorosas - pois pretensamente científicas - versões diabolizadoras do tuberculoso. Ditando a possível lógica da sociabilidade que deveria vigir nos grandes centros urbanos, a literatura e a medicina, por extensão, definiam os estreitos limites existenciais permitidos para as vítimas diretas do Grande Mal. 
1 O mensário Viver! teve seu primeiro número datado de junho de 1938, encerrando sua publicação na década de 50. Seu principal editor foi o engenheiro e político Samuel Ribeiro, filho de uma família pertencente à elite estadual paulista. Para o público especializado nas ciências médicas surgiu a Medicina Germânica, revista que traduzia os principais ideais nazi-fascistas sobre o corpo e a moral. A coleção Medicina Germânica foi inaugurada em 1932, finalizando suas atividades uma década depois, quando o Brasil declarou guerra ao Eixo. Entre os redatores nacionais desta série encontravam-se nomes de destaque da clínica carioca, tais como: Afrânio Peixoto, Affonso Mac Dowell, Vital Brasil e Clementino Fraga. 
Parte II

\section{Personagens e Cenários}

O Homem é o Homem e sua circunstância.

José Ortega y Gasset 
As múltiplas qualificações impostas à tuberculose e aos doentes do peito instruíram as reações pessoais e coletivas, tanto no interior da comunidade dos pectários quanto na dos sadios.

No encadeamento dos fatos, tornou-se conveniente para todos a definição dos ambientes apropriados para os tísicos, motivando as existências infectadas a procurarem abrigo e respostas de vida nas casas de saúde especializadas, nas residências particulares e nas pensões localizadas nas cidades-sanatórios. 


\section{6 \\ A Trajetória do Desterro}

Fraco do pulmão! Tombar essa palavra numa casa era tombar o raio. Fraco do pulmão! Compreendi, num relance, o que significava os olhos vermelhos de minha mãe e a comiseração dolorida dos meus irmãos. Fraco do pulmão (...) Fraco do pulmão? Ah, quem poderia jamais escapar à desgraça?

Foi com estas palavras de espanto e desalento que Paulo Setubal (1949:105) relatou o instante da descoberta familiar da tísica que o mataria um ano após registrar em diário o primeiro encontro com a tuberculose.

Doente de cama em razão de ‘forte resfriado’, um clínico foi chamado para atender o escritor. Após proceder aos exames de praxe, o facultativo retirou-se silenciosamente do quarto do paciente, palestrando longos minutos com a mãe e os irmãos do doente. O que foi tratado entre o facultativo e a família Setubal ficou em segredo, mas a constatação da 'fraqueza pulmonar' era o eufemismo utilizado pela medicina para informar o estado consuntivo do paciente. As palavras ‘tuberculoso’ e ‘tísico’ constituíamse em termos evitados nos pronunciamentos dos esculápios de família, sob a alegação de que o emprego de tais terminologias servia apenas para desesperar os infectados e os seus acompanhantes.

Abatido com a invasão da peste no ambiente doméstico, o grupo familiar reagia não só com lágrimas, mas também com um ambíguo sentimento de solidariedade ao infectado. Isto porque, ao mesmo tempo que se buscava oferecer redobrado conforto ao consuntivo, este era redefinido como figura incômoda, tanto pelo risco de contaminar os sadios, quanto pelos custos e intensidade dos cuidados exigidos pela enfermidade. Acrescia-se ainda o fato da permanência do tuberculoso em casa poder ganhar o conhecimento público, tornando-se então mácula inibidora da teia de sociabilidade da família envolvida. Por isto, a sentença clínica transformava-se em segredo guardado a sete chaves, evitando-se assim que o clã se convertesse em alvo de depreciativas cogitações cochichadas pela vizinhança curiosa.

A tendência dominante era que a família do tísico somasse forças e recursos pecuniários para promover a transferência do enfermo para um dos locais recomendados para a recuperação da saúde pulmonar. Tornou-se corriqueira a situação em que os 
parentes que compartilhavam do segredo juntavam-se numa espécie de conselho clãnico para discutir o imediato envio do consuntivo para um ambiente considerado propício à cura pulmonar.

Naquele momento tudo era acertado: as possibilidades de financiamento da assistência médica, cartas de recomendação que poderiam agilizar o internamento hospitalar e até a escolha da pessoa que se encarregaria de acompanhar o fimatoso ao local indicado para o confinamento sanitário, sendo que parecia relativamente fácil impor aos enfermos mais jovens o isolamento em área distante. O mesmo não ocorria, porém, com os doentes adultos e que reuniam condições físicas, recursos econômicos ou pelo menos prestígio suficiente para se opor à decisão tomada pelos seus parentes.

O horror à reclusão hospitalar freqüentemente se associava às dificuldades de sobrevivência material dos eventuais dependentes do chefe de família assaltado pelo bacilo de Koch. O receio de deixar a mulher e os filhos desamparados fazia com que os trabalhadores pobres ou remediados evitassem procurar assistência sanatorial, preferindo recorrer a formas paliativas de tratamento médico, sob a condição de não ter a vida produtiva bruscamente interrompida.

É corriqueiro encontrar nas anamneses clínicas depoimentos semelhantes ao prestado pelo marceneiro espanhol Antonio Báo (P. 418) que, com o pouco de dinheiro que ganhava com o seu trabalho, sustentava a mulher e cinco filhos menores. Aos 36 anos de idade, Antonio foi surpreendido por uma hemoptise no momento em que trabalhava em uma serraria estabelecida na zona norte paulistana. Conduzido a um posto médico localizado nas proximidades da oficina em que atuava, o marceneiro foi medicado e imediatamente reconhecido como tuberculoso.

Mesmo assim, Antonio voltou ao trabalho no mesmo dia, restringindo o seu tratamento a consultas mensais a 'um medico da rua Vergueiro', que lhe administrava injeções de cálcio e fortificantes. Sob tais condições, o operário permaneceu trabalhando por mais cinco anos, sendo internado no Hospital-Sanatório São Luiz Gonzaga pela esposa somente em 1935, quando a fraqueza que minava o seu organismo chegou a tal ponto que, extenuado, o tísico nem mesmo conseguia levantar da cama.

Casos tristes de rejeição ao estado fimatoso se repetiam em série, destacando-se o da órfã Maria Gomes de Oliveira (P. 3639), que soube estar adoentada aos 19 anos de idade. Desconhecendo sua parentela, Maria Gomes abandonou a instituição de caridade que a criou desde a tenra infância e encontrou emprego de doméstica em um sobrado de classe média, localizado no paulistano bairro do Belenzinho.

Após ‘tomar gelados quando estava suada', Maria sentiu os primeiros sintomas da tísica, recorrendo a um clínico que diagnosticou 'fraqueza pulmonar'. Não acreditando na sentença hipocrática, a doméstica continuou no emprego, sem nada informar aos seus patrões, seguindo com eles para um período de férias na cidade de Santos.

No litoral, Maria Gomes sentiu novamente os efeitos da infecção, internando-se na Santa Casa, local onde - ainda segundo ela - submeteu-se ao esmagamento de um dos nervos frênicos, cirurgia explicada posteriormente como 'em consequencia de uma forte pancada no peito'. Regressando ao sobrado do Belenzinho, a empregada passou a eliminar sangue no escarro, fato que a coagiu a procurar consulta na Santa Casa de São Paulo, onde uma vez mais foi informada sobre seu estado consuntivo. 
Ainda 'não acreditando no resultado dos exames', a enferma consultou os especialistas do Dispensário Clemente Ferreira, onde novamente foi reconhecida a sua moléstia pulmonar, sendo-lhe prescritas várias sessões de pneumotórax. Maria Gomes negava-se a aceitar seu estado consuntivo, terrível drama que feria uma vida por tudo trágica. Inabalável na decisão de permanecer no trabalho ocultando a condição fimatosa, a enferma persistiu na atividade de serviçal até ser acometida por uma forte hemoptise testemunhada pelos patrões que, ato contínuo, encaminharam-na para tratamento no Sanatório do Jaçanã.

Os compromissos familiares impunham aos enfermos mais humildes o não afastamento da faina diária. A ausência de amparos oferecidos por parentes ou amigos tornava ainda mais difícil a aceitação do estado infeccioso e o conseqüente isolamento.

\section{As Versóes do Isolamento}

Eram reduzidas as opções de encaminhamento da vida para as vítimas da Peste Branca que evitavam o pronto internamento hospitalar. A tisiofobia reclamava reações coletivas frente aos infectados, tornando torturante a permanência dos pectários no ambiente social que lhes tinha sido familiar até a revelação da moléstia. O redimensionamento existencial imposto pela 'fraqueza pulmonar' favorecia dolorosas rupturas no dia-a-dia, estabelecendo um 'antes' e um ‘depois' na biografia dos contaminados.

Quando o consuntivo conseguia fazer aceitar a sua permanência junto ao agrupamento doméstico, ele percebia que pouco a pouco ia sendo despojado do cotidiano reservado às pessoas saudáveis. Seguindo as orientações médicas, sempre que possível a família reservava um dos cômodos da residência para a acomodação exclusiva do pectário, que também passava a contar com roupas de cama, pratos, copos e talheres de uso próprio.

Na seqüência dos acontecimentos, a maior parte dos conhecidos deixava de freqüentar os aposentos do enfermo, limitando-se a conversas rápidas e encabuladas, postados na soleira da porta. Por fim, os amigos que até então haviam se mostrado cordiais e solícitos começavam a rarear visitas, sabendo da presença da Peste Branca ou pelo menos desconfiados que algo terrível e ameaçador pairava sobre a residência do companheiro adoentado.

O constrangimento produzido pelo redimensionamento das relações sociais mais íntimas somava-se ao desconforto gerado pelo reconhecimento público dos traços que, de regra, a moléstia impingia ao corpo infectado. Foi por causa disso que, no ano de 1944, uma jovem trabalhadora fimatosa que evitou as malhas sanatoriais assim confidenciou o dilema gerado pelo convívio com os amigos do tempo de saúde:

Encontrei um ex-colega de escola, no dia 21 de janeiro... Desagradou-me o encontro; evito o mais possível essas situações que são para mim um martírio. Desliguei-me das velhas relações e, ao mesmo tempo, evito novos conhecimentos. Faço vida arredia, vivendo de mim para mim. (Apud Nogueira, 1945:22) 
A luta pela permanência dos consuntivos no universo dos sadios revelava-se arriscada aventura. O segredo sobre o estado fimatoso era recoberto de silêncio, evidenciando ainda mais as teias da solidão.

O olhar cauteloso instruído pela tuberculofobia imperante, em especial na primeira metade deste século, esquadrinhava o tecido social, comprazendo-se em reconhecer os tísicos e, de imediato, acusar os doentes da macabra tarefa de disseminação proposital do germe da morte.

Alguns depoentes que falaram sobre as condicionantes que levaram ao enfermamento consuntivo não pouparam esforços em denunciar a perversidade dos tuberculosos como motivo definidor do contágio. O Dr. Pinheiro foi um dos inúmeros clínicos fimatosos que, na abertura da década de 30 , rumou para a estância climatoterápica de São José dos Campos, permanecendo até recentemente naquela cidade. No curso de uma entrevista, quando foi indagado sobre as causas de sua moléstia pulmonar, o velho médico prontamente informou que tinha sido contaminado no interior fluminense, muitos anos antes da patologia anunciar seus primeiros sintomas, acrescentando que:

Não quero comprometer a minha tia Izaura. Ela era muito doentia. Eu me lembro
que era pneumonia, e quando minha mãe foi para a cidade para tratar dos dentes,
eu fiquei lá em casa com minha tia, e dormi na cama com ela e tem mais possibi-
lidade disso [ser o motivo determinante da infecção tísica] porque eu tive mais
três irmãos e nenhum teve coisa alguma. (...) Então tive um contágio direto (...) e
minha contaminação se deu com ela.

Outro entrevistado, alinhando informações reunidas junto a oito parentes que sobreviveram à infecção consuntiva, informou que seu clã acredita que o contágio grupal se deu por meio do convívio ‘praticamente íntimo e diário' com uma família de negros, também afetada pelo Grande Mal:

A tia Alzira nasceu em janeiro de 1936 e morreu em outubro ou novembro de 1938, de tuberculose. Ficou doente apenas um ou dois meses antes de morrer. Minha família achou que foram os negros que passaram a doença para a Alzirinha e, por causa disso, meu avô e outros vizinhos se juntaram, invadiram a casa dos negros e surraram toda a família. Eu acho que nem mesmo os negros sabiam que eram doentes e não foi por mal que passaram a doença. Acho que foi por ignorância e não por maldade. Mas o meu pai - que também logo depois ficou tuberculoso - até hoje acha que foi por maldade e quando se lembra dos acontecimentos sempre diz: "àqueles pretos filhos da puta!”

Fatos como esses deixam claro que o anonimato prometido pelos centros urbanos maiores era um privilégio impossível para os doentes do peito. O receio à estigmatização e o horror de ser execrado publicamente sugeriam aos fimatosos o afastamento dos ambientes que até há pouco lhes pareciam seguro, pois familiar.

Novamente a partida para o exílio hospitalar aflorava como alternativa possível, mas a rejeição ao rompimento definitivo com os quadros cotidianos reclamava que outras medidas fossem colocadas à prova. Como opção, os pectários mais ricos preferiam buscar socorro no estrangeiro, especialmente na Europa alpina. Ribeiro Couto, Afonso Arinos de Melo e Franco, Manuel Bandeira, Sergio Milliet e Adhemar de Bar- 
ros, dentre outros, foram tísicos que recorreram ao tratamento oferecido pelos sanatórios suíços e alemães, representando apenas uma ínfima parcela dos membros contaminados da elite brasileira que, discretamente, rumaram para a Europa em busca de assistência médica.

Afonso Arinos (1961) recordou com uma certa nostalgia o ano e meio que permaneceu hospedado em várias casas de saúde européias, inclusive no sanatório comandado pelo Dr. Jacques Stéphani. Acompanhado da mulher, Ana, e pelo amigo, Ribeiro Couto, também tuberculosos, o intelectual e político retratou o cotidiano dos consuntivos endinheirados como algo bem distante do clima marginalizador que pairava sobre os fimatosos pobres no Brasil.

Os filtros da memória e a discrição impuseram que Afonso Arinos pouco se ativesse às angústias geradas pela condição enfermiça, preferindo ressaltar a estada na Suíça como uma sucessão de viagens de recreação e de encontros sociais que, no final, deixam a impressão que os tísicos estavam envolvidos em uma espécie de expedição turística, e não na procura do restabelecimento da saúde pulmonar.

Outros fimatosos brasileiros serviram-se da condição de hóspedes sanatoriais para tratar da saúde e também obter aperfeiçoamento em diferentes áreas da medicina. O enfermo Dr. Adhemar de Barros foi obrigado a permanecer três anos em nosocômios suíços e alemães, regressando no final deste período não só com os pulmões curados como também com o diploma de especialização em urologia e ginecologia.

Outro clínico, o pernambucano Alberto Cavalcanti, foi para os Alpes em busca de assistência hipocrática, mas também aprofundou seus conhecimentos em tisiologia e administração hospitalar. De regresso à sua pátria, o Dr. Cavalcanti instalou-se no sul mineiro, tornando-se proprietário de vários sanatórios particulares naquele estado.

Os enfermos que contavam com recursos limitados, por sua vez, vagavam por distintas cidades brasileiras, não diretamente alinhadas como estação de tratamento dos pulmões, tanto para fugir da companhia de outros enfraquecidos do pulmão quanto para evitar que seus conhecidos concluíssem acertadamente sobre a moléstia que vinha minando o organismo do pectário.

Assim, cada estado passou a contar com uma ou mais cidades que ganharam certa fama como 'áreas de descanso', sendo que as informações registradas nos prontuários clínicos apontam que os tuberculosos paulistas buscavam refúgio e privacidade em localidades como São Bernardo do Campo, Rio Grande da Serra, Paranapiacaba, Bragança Paulista, Atibaia, Itú, Salto, Cabreúva, Porto Feliz e Tietê.

O consuntivo Paulo Setubal evitou o quanto pôde os distritos sanatoriais, fazendo-se peregrino na região sul do país, só aceitando fixar residência em São José dos Campos quando pressentiu a proximidade da morte.

O poeta Rodrigues de Abreu - sintomaticamente cultuador da memória e dos versos de António Nobre - também buscou ocultar o seu estado infectado, imitando a estratégia de contínuos deslocamentos ensinada pelo autor de Só. Natural de Capivari, Rodrigues de Abreu instalou-se sucessivamente nas cidades de São Paulo, Bauru, Piracicaba, Sorocaba, Pirajuí, Tatuí, São Roque, Porto Feliz e Atibaia, encontrando a morte nesta última localidade, no momento em que estava para ser expulso da casa que alugara, porque o senhorio havia descoberto que o inquilino estava com os 'pulmões estragados'. 
As estratégias de fuga aconselhavam como local de isolamento as áreas que somassem a qualidade climática com a presença de parentes ou conhecidos que pudessem prestar auxílio caso houvesse repentino agravamento da saúde. A memorialista Maria Helena Cardoso (1968), moradora no município de Curvelo - uma cidadezinha encravada na região central de Minas Gerais -, registrou o momento em que sua família hospedou uma prima distante e minada por uma 'fraqueza' que, logo nos primeiros momentos de contato, os anfitriões concluíram ser a assustadora tuberculose.

Apesar ou porque os pais da escritora foram eles próprios tísicos na juventude, a viajante foi acolhida com todas as reticências. Oferecendo quarto individual e objetos de uso privativo para a parente enferma, os Cardoso não ficaram sossegados, descobrindo na consuntiva o 'desejo doentio' de contaminar os sadios, especialmente as crianças da casa. Por isto, a família montou um rígido esquema de vigilância para indiscretamente vasculhar todos os atos da indesejável visita.

Maria Helena Cardoso (1968:182) arremata as informações sobre aquele período de sua vida, assumindo em sua narrativa os estigmas imputados aos tuberculosos:

Além de tudo, toda a vigilância era pouca para que [a pectária] não se misturasse conosco, propositadamente. Se mamãe saía, nos recomendando à cozinheira, mal se distraía, ela apanhava o pequeno e nos atraía ao seu quarto, engodandonos com pedaços de doce, restos do seu prato. Um dia, chegou mesmo a fazer o pequeno sugar cascas de jabuticabas que ela tinha chupado.

Ao saber do ocorrido, a progenitora da memorialista decretou: "não era mais possível arriscar a saúde dos filhos". A prima tuberculosa foi expulsa do refúgio mineiro, sendo então internada em um sanatório fluminense, onde encontrou a morte pouco tempo depois.

Como a prima de Maria Helena, muitos outros doentes procuraram abrigo em locais afastados de suas origens. O musicista e poeta Noel Rosa foi outro tísico que se viu furtado de seus principais amigos logo que se espalhou a notícia de seu estado consuntivo. A doença e a solidão fizeram com que o fracassado aluno da faculdade de medicina carioca abandonasse sua querida Vila Isabel e buscasse refúgio na distante Barra do Piraí.

Instalado em uma pensão na companhia de sua namorada, o corpo decrépito, o gesto sempre tímido de falar com a mão na boca para não contaminar o interlocutor e as manchas de sangue localizadas na fronha e no lençol da cama do ilustre hóspede fizeram com que a dona da pensão exigisse a imediata partida do infectado. No momento em que abandonava a estalagem, o poeta enfermiço ainda teve tempo de testemunhar o horror que a doença inspirava nos sadios: tomada pelo medo, a anfitriã lançou na rua o colchão utilizado por Noel, ateando fogo na peça ao mesmo tempo que esconjurava a demora em partir do tuberculoso. Corria o primeiro mês do ano de 1937. Em maio, Noel Rosa estava morto.

Definitivamente, parecia não existir lugar para os tuberculosos no território dos sadios. Rejeitados pelos parentes e evitados pelos amigos, os pectários faziam uma última avaliação da tentativa de continuar vivendo afastados dos ambientes sanatoriais, refletindo sobre a própria periculosidade da condição infectada. Afinal, não teriam 
razão as vozes que divulgavam que os consuntivos compunham um grupo tão horripilante quanto os 'sifilíticos, leprosos, cancerosos e todos os párias do mundo? Não estariam certas as pessoas que insistentemente cobravam das autoridades o urgente 'sequestro e detenção' dos tuberculosos porque, propositalmente ou não, infectavam todo o grupo doméstico? E, ainda mais, não seriam verídicas as notícias que afirmavam que a cura dos pulmões só era realidade possível se o enfermo se acomodasse por longos períodos nas estâncias climatoterápicas?

Sem respostas conclusivas para estas e muitas outras questões, os consuntivos buscavam avaliar as alterações que a peste estava provocando no seu físico, tentando de alguma forma negar a versão popular que pontificava que, à meia-noite das sextasfeiras de lua cheia, os 'bichados das costas' trocavam o semblante de infeliz, muito magro, macilento e taciturno pelo aspecto aterrorizante do 'homem-lobo'.

O espelho era consultado e a resposta era dolorosa, dolorosa demais, como confidenciou o fimatoso Nelson Rodrigues: "Lembro-me que, um dia, fui me olhar no espelho. Era como se, por equívoco, o espelho estivesse retransmitindo outra imagem” (1967:117).

Em outra passagem da coleção de reminiscências, o dramaturgo atestou o pavor à figura reproduzida pelo cristal refletor, tornando seu o horror coletivo lançado sobre os corpos consumidos pela tísica:

- Minha cama dava para o espelho. Via em cada olho um halo negro; as minhas faces estavam escavadas; e tinha a sensação de que olhava o meu próprio cadáver. Pedi, pelo amor de Deus, que cobrissem o espelho com o lençol. (1967:117)

O corpo abatido, a face enfeiada, a contínua 'falta de ar', a ausência de amparo solidário e a escassez de recursos econômicos para patrocinar o tratamento completavam o quadro do martírio e da rejeição. Como constatou Nelson Rodrigues, de tudo o que ocorrera desde a declaração da enfermidade, só restara o amargo sentimento de ausência de amor, inclusive de amor-próprio. A partir de então, para o tuberculoso parecia só existir uma única alternativa: o rumo ao isolamento sanatorial.

O tísico ganhava ciência de que se tornara um personagem incômodo e ameaçador, principalmente para as pessoas que o amavam. Em vários interrogatórios clínicos registrados no Hospital do Jaçanã o termo 'imprestável' foi anotado como parte da declaração do paciente. Sim, o consuntivo se sentia imprestável, para si e para os outros. Tomada a decisão do isolamento nosocomial, uma nova luta tinha início, motivada pela necessidade de reunir recursos econômicos ou obter guarita filantrópica suficiente para custear os altos preços da hospitalização. Concluía-se assim a primeira morte dos infectados, a morte social.

\section{Nos Meandros da Caridade}

A conquista de uma vaga sanatorial não era coisa fácil. Disputados entre aqueles que podiam pagar e aqueles que nada tinham para retribuir, os leitos hospitalares eram poucos e caros, sendo corriqueira a situação dos enfermos baterem à porta de uma 
casa de saúde portando cartas de apresentação de médicos, políticos e religiosos, tentando com isso agilizar o início do isolamento sanitário.

A concentração dos infectados nas estâncias climatoterápicas do estado de São Paulo conferia grande dificuldade para a obtenção de uma vaga hospitalar, fato que aconselhava os doentes a recorrerem primeiramente às instituições assistenciais localizadas na capital bandeirante, onde parecia ser mais fácil ganhar um leito em casa de saúde especializada, o qual serviria como porta de entrada para o sistema sanatorial. A documentação referente ao Hospital São Luiz Gonzaga deixa perceber que a lista de espera por uma vaga era extensa, podendo demorar até mais de um ano para o tuberculoso inscrito conseguir um leito na enfermaria daquele sanatório.

O descompasso entre o número de tísicos e as oportunidades de internamento fazia multiplicar as cenas chocantes que feriam o cotidiano da cidade de São Paulo. Nos prontuários médicos é relativamente comum o registro de casos como o protagonizado pelo carroceiro Henrique Barreiros (P. 1875) que, vindo de Iguape, esperou por uma vaga hospitalar durante vários meses, sendo que neste período permaneceu hospedado no Albergue Noturno do município.

A data para internamento parecia algo incerto e distante até que, no primeiro dia de dezembro de 1943 o enfermo foi acometido por forte hemoptise quando perambulava nas proximidades da Praça da Sé, momento em que foi socorrido por uma ambulância da Assistência Pública. Em estado preagônico, o tuberculoso finalmente ganhou um leito no pavilhão reservado aos indigentes no Sanatório do Jaçanã, mas pouco pôde usufruir do tratamento especializado, pois, uma semana após ser recebido no hospital, Henrique Barreiros chegou a óbito, extenuado pela continuidade dos vômitos sangüíneos.

A repetição de situações envolvendo tísicos terminais ampliava ainda mais o receio nutrido pelos enfermos de encontrar a morte nos espaços públicos da cidade. Foi por isto que Joaquim Franco de Godoy (P. 312), um desempregado de cerca de 30 anos de idade, tomou uma decisão inusitada em maio de 1935, quando foi informado que não havia previsão de data para a abertura de vagas para internamento e nem mesmo para consultas ambulatoriais no sanatório paulistano da Santa Casa.

Inconformado com o descaso institucional para com os desamparados como ele, Joaquim permaneceu 'encostado no muro do hospital' pelo prazo de uma semana. Esgotado este período, o suposto doente aproveitou o descuido do porteiro da entidade e invadiu a área nosocomial, refugiando-se em um leito desocupado da enfermaria de indigentes. O fato de o paciente reagir com violência às tentativas para desalojá-lo resultou no desejado atendimento médico, sendo que o plantonista encarregado da sua anamnese, concluiu que a ‘tosse e acessos de chiadeira e ronco no peito' nada mais eram que o resultado de uma 'bronchite banal'. Cientificado do diagnóstico, Joaquim Franco de Godoy deu-se por satisfeito, abandonando espontaneamente o recinto sanatorial.

A luta pela obtenção de atendimento nos sanatórios filantrópicos não era apanágio exclusivo dos filhos da pobreza. Nas filas de espera por assistência médica mesclavam-se proletários e membros dos estamentos médios da sociedade, que já haviam gasto todo o dinheiro acumulado nas tentativas de recuperar a saúde. 
A biografia sanitária do engenheiro Newton Barreiro (P. 1535) constitui-se em um significativo exemplo dos labirintos percorridos pelos enfraquecidos do peito. Integrante de uma linhagem marcada por sucessivos óbitos consuntivos, Newton soube estar tuberculoso nos primeiros dias do ano de 1942, quando 'uma forte gripe seguida de abundante expectoração e hemoptise' o fizeram abandonar o comando da construção de uma barragem, na Baixada Fluminense. Imediatamente, o engenheiro buscou consulta com o tisiologista carioca Affonso Mac Dowell, o qual aconselhou a rápida transferência do paciente para a estação de Campos do Jordão.

A acentuada perda de peso e também a 'perturbação mental' que o fez supor estar ficando "louco" impuseram que Newton acatasse sem reticências a orientação médica, levando o engenheiro a obter uma vaga como paciente pagante no Sanatório Santa Cruz, uma das mais caras casas de saúde instalada na Serra da Mantiqueira.

Porém, bastaram apenas seis meses de internamento para que se esgotassem os recursos econômicos do paciente que, num momento em que apresentava 'sensível recuperação orgânica e mental', foi obrigado a abandonar aquele nosocômio. Sem outra saída, Newton Barreiro pediu assistência ao Hospital São Luiz Gonzaga, recebendo um catre pago pela caridade, em janeiro de 1943. Em apenas um ano de convívio íntimo com a Peste Branca, o engenheiro havia se transformado em paciente indigente, mesmo que, na documentação nosocomial, o nome do doente fosse precedido do respeitável título de doutor.

$\mathrm{O}$ acesso a uma vaga sanatorial não colocava fim à peregrinação dos tísicos, especialmente daqueles que estavam sendo assistidos pelos médicos do Hospital do Jaçanã. Isso porque esta casa de saúde ganhara prestígio como centro tisiocirúrgico, fazendo com que os tuberculosos que depositavam confiança na climatoterapia ou que queriam fugir das operações torácicas pedissem 'permuta' por enfermos que, instalados nos sanatórios das prefeituras sanitárias, precisavam ser submetidos ao tratamento operatório oferecido pelos médicos da Santa Casa paulistana.

O acúmulo de pedidos de transferência para os nosocômios localizados nas estações de cura chocava-se com um certo 'isolacionismo' que imperava no Hospital São Luiz Gonzaga, resultando no pequeno número de troca de pacientes com outros centros de tratamento especializado. Por isto, o comum era os tuberculosos em melhor estado físico pedirem alta 'por conta própria', rumando para as estâncias sanitárias sem qualquer amparo institucional, contando apenas com a sorte ou com a solidariedade alheia para conseguir um novo leito gratuito.

\section{A Geografia da Esperança}

A indicação das localidades paulistas como centro de tratamento climatoterápico ganhou estímulo a partir do final do século passado. Antes desta data, as regiões de clima seco e relativamente ameno, situadas no nordeste brasileiro, eram as áreas preferidas pela medicina, constituindo-se nos espaços que serviam de refúgio para os fracos do peito. 
Desde que a clínica européia havia incluído as regiões de clima frio como possibilidade curativa dos fimatosos, o estado de São Paulo passou a receber os pectários que, desencantados com as promessas do clima nordestino, recorreram às partes do sul do país como nova opção natural para o tratamento da saúde. No ano de 1868, por exemplo, o tuberculoso Castro Alves permaneceu por algum tempo no 'burgo dos estudantes', freqüentando a Faculdade de Direito. Desolado, o poeta avaliou a terapêutica capital dos paulistas: “aqui não há senão frio, mas frio da Sibéria” (1960:753).

No mesmo período, o Prof. Torres Homem (1882) ensinava aos seus discípulos que a cura da consunção poderia ser obtida por meio da permanência dos enfermos em climas apropriados, localizando-os tanto no interior da Bahia e nas cidades marítimas, quanto nas regiões de clima frio, sendo então mencionados o norte do Paraná, o sul de Minas Gerais e os distritos paulistas de Campos do Jordão, Areias, Araraquara, Sorocaba, Piracicaba e Itú. Na seqüência, o médico alertava que fazia seus clientes tuberculosos estabelecerem temporariamente residência na cidade vale-paraibana de Cunha, onde, segundo ele, sem o uso de qualquer remédio, "todos retornavam a condição de saúde e felicidade".

Superado meio século desde a publicação dos conselhos de Torres Homem, os manuais clínicos haviam eliminado de suas linhas quaisquer referências sobre a qualidade dos ares do sertão ou da praia como favorecedores da saúde comprometida pela tísica. Os novos ensinamentos médicos apontavam que, apesar da existência de leitos destinados aos pectários em algumas Santas Casas do interior paulista, apenas duas localidades constituíam-se em áreas exclusivas para o tratamento dos tuberculosos: São José dos Campos e Campos do Jordão.

Seguindo esta tendência, quando era constatada a inevitabilidade do exílio, os doentes do peito imediatamente voltavam-se para as estações de cura paulistas como meta geográfica a ser atingida. As propagandas alimentadas sobre a qualidade do clima do Vale do Paraíba e da Serra da Mantiqueira assim como a concentração de leitos e serviços tisiológicos naquelas regiões alçaram as cidades sanitárias à condição de esperanças últimas para muitos enfermos, constituindo-se em motivos de respeitosas reverências, anotadas nos diários e na troca de missivas de vários intelectuais brasileiros que incidentalmente discorreram sobre o assunto, no transcorrer das décadas de 30 e 40.

\section{Sĩo José dos Campos}

Desde que as lições médicas informaram que a cura dos tuberculosos poderia ser alcançada na parcela paulista do Vale do Paraíba, a região nordeste do estado passou a acolher um número cada vez maior de enfraquecidos do peito. Já no final do século XIX, o município de Cunha assumiu a posição de principal centro bandeirante de afluxo de fimatosos, atraindo enfermos de todos os quadrantes do país.

O médico negro e consuntivo Alfredo Casemiro da Rocha foi um dos tantos pectários que abandonou sua terra natal em busca da saúde. Nascido na Bahia, o Dr. Casemiro instalou-se em Cunha para tratar dos pulmões, permanecendo o resto de sua 
vida na região, tempo suficiente para se transformar em um dos mais destacados coronéis da política local (Nogueira, 1992).

Na seqüência, a cidade de São José dos Campos angariou fama de cidade sanitária do Vale do Paraíba, principalmente a partir da segunda década do século passado, quando o médico tísico Nelson Silveira D’Avila disseminou a notícia de que, graças ao clima joseense, tinha reconquistado a saúde comprometida. A partir de então, o município ganhou os cognomes de 'Nice brasileira' e 'Tepelândia', atraindo um número cada vez maior de infectados.

A presença de enfermos no município, localizado às margens da estrada de ferro e da rodovia que ligam São Paulo à capital da República, incentivou que no solo joseense fosse erguido o primeiro sanatório para tuberculosos do estado de São Paulo, precedido em nível nacional apenas pelo mineiro Sanatório de Palmira, inaugurado em 1920.

Patrocinado pela Santa Casa de Misericórdia paulistana e pela família do senador e banqueiro Olavo Egydio de Souza Aranha, a casa de saúde vale-paraibana ganhou o nome da esposa do político, Vicentina Aranha, entrando em funcionamento a partir do mês de abril de 1924, com aproximadamente uma centena de vagas, número pouco alterado no decorrer dos anos anteriores a 1945. Apesar dos compromissos caritativos da instituição, os leitos do nosocômio eram prioritariamente reservados para os pacientes que podiam pagar o tratamento e a hospedagem, com recursos próprios ou graças aos apoios oferecidos pelas Caixas setoriais ou ainda pelas companhias de seguro.

A inauguração desse hospital fez crescer ainda mais o contingente de enfermos estabelecidos na região, favorecendo a instalação de outras unidades especializadas no tratamento dos tísicos. Com isso, o município - cuja história definia-se pela pobreza crônica - encontrou incentivo econômico, conseguindo relativo incremento da receita com os forasteiros enfermiços, sendo alçado à condição de estância climática, por decreto governamental datado de 1935.

Procurado inclusive por tísicos de posses que adquiriam chácaras nas vizinhanças dos sanatórios, São José dos Campos atraiu inúmeros clínicos interessados no tratamento da própria saúde, na capacitação no saber tisiológico e também nos lucros proporcionados pela especialidade médica. Nesse processo, a Tepelândia passou a contar com uma dezena de sanatórios, sendo que o nosocômio que mais prestígio acumulou nesse período foi o pertencente ao facultativo fimatoso Ruy Rodrigues Dória.

Nascido na cidade paulista de Limeira, o Dr. Dória recebia em seu hospital apenas pacientes particulares, ganhando reputação nacional graças às intensas campanhas publicitárias realizadas em nome do seu estabelecimento.

Apresentado como hospital equipado com instrumentos sofisticados e funcionando segundo o "methodo norte-americano" que unia "o mais adeantado conhecimento da tuberculose” com "principios modernos, rigorosos e scientificos de tratamento”, o Sanatório Ruy Dória alertava aos interessados que mantinha convênio com uma rede de hotéis e pensões da região, abrigando nessas hospedarias os doentes que não dispunham dos $800 \$ 000$ cobrados mensalmente pela residência no nosocômio.

Graças ao prestígio de sua empresa, o Dr. Dória acumulou riqueza e influência suficientes para se tornar prefeito municipal e líder da política vale-paraibana durante o 
período varguista, tendo como único adversário na arena política outro tisiologista tuberculoso de renome nacional: Rodolfo dos Santos Mascarenhas. Nascido em São José dos Campos, o Dr. Mascarenhas, ainda na década de 30, também ocupou o cargo de prefeito municipal da urbe sanitária, tarefa que buscou compatibilizar com a docência exercida junto ao Instituo de Higiene da Universidade de São Paulo.

Nem todos os infectados que chegavam na estância joseense reuniam condições para usufruir da assistência vendida pelos sanatórios. A escassez de dinheiro e a falta de amparos patrocinados pela solidariedade pública faziam da cidade reduto de enfermos mendigos, afugentando os habitantes sadios que reclamavam urgentes medidas das autoridades públicas.

A reforma sanitária estadual, promovida em 1938, buscou fazer do Centro de Saúde recentemente instalado no município a sede de normatização da vida na estação de cura. O 'controle da tuberculose' tornou-se um conceito dissimulador que, registrado insistentemente nos relatórios oficiais, justificava a vigilância acirrada sobre os doentes que perambulavam, quase sem rumo, pelo território da Nice tropical.

O olhar perscrutador da Higiene Pública buscava esquadrinhar o espaço joseense, localizando os tísicos desamparados e, não raramente, seqüestrando-os em nome da segurança dos sadios. Colhidos nas malhas policialescas da Saúde Pública, os tuberculosos eram forçados ao isolamento nos pavilhões improvisados ou, mais freqüentemente, eram devolvidos aos locais de onde haviam partido, sendo que para esta finalidade foram criadas várias entidades que, sob a máscara da filantropia, tinham como objetivo afastar da estação vale-paraibana os visitantes infectados e destituídos de recursos pecuniários.

Em nome da acomodação dos consuntivos, as autoridades administrativas de São José dos Campos passaram a exigir mais e mais verbas dos cofres estaduais. A frustração joseense de receber quase nada do que era pedido aos interventores federais devia-se ao fato de que a Serra da Mantiqueira, bem mais do que o Vale do Paraíba, constituía-se no eldorado perseguido pelos tísicos. Eram as áreas localizadas serra acima que afloravam como o espaço seguro de cura dos doentes do peito, sendo que para muitos o território joseense revelava-se apenas como um pálido átrio para as benesses prometidas pelos 'ares serranos' ou local de confinamento dos pectários que não suportavam o ‘clima de altitude'.

\section{Campos do Jordẽ̃o}

O início da presença de tuberculosos na Serra da Mantiqueira remonta ao ano de 1879, quando os clínicos consuntivos Francisco Romeiro e Gustavo de Godoy, discípulos da medicina germânica, patrocinaram a construção de alguns chalés para acomodar a eles próprios e também alguns de seus pacientes infectados.

Poucos anos depois, os Drs. Clemente Ferreira e Luis Pereira Barreto percorreram a região, divulgando, por meio da imprensa paulista, a qualidade salutar e reconstitutiva dos ares do município de São Bento do Sapucaí, que na época tinha 
Campos do Jordão como um de seus distritos. Assim, desde a penúltima década do século XIX, a localidade já se tornara objeto de várias campanhas que reivindicavam a construção de sanatórios na Serra da Mantiqueira. Na falta de casas de saúde, o clima e a beleza natural das montanhas foram invocados na tentativa de atrair grupos de turistas, alertando-se os viajantes de que os espaços de descanso estavam rigorosamente proibidos para os pectários que eventualmente afluíssem para aquela localidade.

A ausência de estradas minimamente confortáveis impunha que os viajantes que partiam do Vale do Paraíba fossem transportados para Campos do Jordão em lombo de burro ou em liteiras. Um caminho de ferro que ligaria a cidade de Pindamonhangaba com a estação de cura começou a ser construído em 1912, sendo completado 12 anos depois, a expensas do governo estadual. Ao ser inaugurada a linha férrea, o povoado de Campos do Jordão já contava com vários núcleos populacionais e com aproximadamente uma dúzia de pensões - algumas de luxo, outras míseros barracões - que abrigavam centenas de fimatosos em busca de recuperação da saúde.

Ainda no ano de 1924, o político e intelectual José Carlos de Macedo Soares organizou a Companhia Campos do Jordão, incorporando vastas glebas de terra, inclusive uma propriedade que Emílio Ribas e Victor Godinho tinham adquirido em sociedade, na década anterior.

Coube a esta empresa o papel pioneiro de aplicar as primeiras regras de segregação dos enfermos que afluíram para a Serra da Mantiqueira, medida que se estendeu nos vinte anos seguintes, mesmo depois das sucessivas reorganizações da vigilância sanitária oficial. Seguindo a orientação estabelecida por Macedo Soares, os lotes situados nas vilas Jaguaribe e Capivari foram reservados para os compradores endinheirados, enquanto a vila Abernéssia ficou destinada à ocupação da população pobre e enferma.

Batizada pelos higienistas e pelos administradores como a 'Suíça brasileira', Campos do Jordão atraiu a high society paulista que buscava a região serrana para desfrutar os períodos de férias. Dentre os primeiros proprietários das mansões joseenses, encontram-se clãs ilustres que, com o subterfúgio de procurar o ambiente da Mantiqueira para se recuperar da agitação metropolitana, possivelmente dirigiam-se para as montanhas para, discretamente, tratar de parentes e amigos contaminados pelo bacilo de Koch.

Dentre os representantes da elite bandeirante que, ainda na década de 20 habitaram a cidadela dos infectados, encontram-se as famílias de Adhemar de Barros, Conde Matarazzo, Ermírio de Moraes, Roberto Simonsem, Gastão Vidigal e Abreu Sodré.

A presença destes grupos influentes junto aos governos estadual e federal fez com que a região, especialmente as áreas onde se aglomeravam os 'turistas' ricos, ganhasse seguidos benefícios públicos e privados. A Companhia presidida por Macedo Soares responsabilizou-se pela instalação das redes de água e esgoto, iluminação elétrica e coleta de lixo, enquanto os cofres públicos patrocinaram a implantação do serviço de correio e também a abertura de uma estrada de rodagem que colocou em contato direto a estação de cura com a cidade de São José dos Campos.

Como resultado, Campos do Jordão passou a ser divulgada como 'um pedaço da Europa incrustado nos trópicos', fazendo com que momentaneamente a vila se tornasse símbolo das esperanças de um país que lutava para se identificar com as 
'nações civilizadas'. Em continuidade, o senador Roberto Simonsem ganhou o apoio da intelectualidade paulista - inclusive de Monteiro Lobato - para desfraldar a bandeira de uma campanha que pretendia transferir a capital da República para a Serra da Mantiqueira, sob a alegação de que o ‘clima de altitude’ predisporia a administração pública em geral e os políticos em particular para o trabalho contínuo e honesto.

A presença de tantas famílias ilustres na região permitiu que Campos do Jordão fosse apresentada ao Brasil como área predominantemente turística. Várias publicações veiculadas pelo governo paulista e datadas da década de 20 empenharam-se em minimizar a presença dos tuberculosos no domínio da Mantiqueira, preferindo descrever a vila serrana como território de descanso e recreação.

A concentração de tísicos nos limites jordanenses transformou-se, entretanto, em algo incômodo e ameaçador, exigindo a intervenção da administração pública. Em conseqüência, Carlos de Campos, presidente do estado de São Paulo, aprovou uma lei que, datada de outubro de 1926, criava a prefeitura sanitária de Campos do Jordão que, permanecendo na condição de comarca de São Bento do Sapucaí, passou a contar com prefeito próprio, nomeado pela esfera estadual.

Inclusive por não dispor de orçamento próprio, a possível constituição de uma Higienópolis cravada nas montanhas foi paulatinamente perdendo credibilidade junto à população. No ano de 1928, Campos do Jordão abrigava uma população de aproximadamente 5.200 pessoas, sendo que não menos de um terço deste total era reconhecido como de indivíduos tuberculosos. Pela vez primeira assumia-se oficialmente que a prefeitura sanitária era sobretudo local de tratamento de pectários, salientando-se a existência de cerca de vinte pensões autorizadas a hospedar os doentes pulmonares.

Nos últimos anos da década de 20, tornara-se impossível ocultar a realidade: Campos do Jordão havia se transformado no principal refúgio nacional dos 'fracos do peito'. Denominada de 'Meca dos tísicos’ e ‘Chanaã dos tuberculosos’ por Clemente Ferreira, a estação serrana cumpria o seu papel de isolante dos doentes, perdendo a condição oficial de território exclusivo do turismo.

Apesar da redefinição da funcionalidade de Campos do Jordão, o governo paulista manteve-se praticamente ausente das obrigações de amparo aos fimatosos que se dirigiam para a Serra da Mantiqueira. Nos primeiros anos de vida da prefeitura sanitária, a cidade não recebeu qualquer tipo de apoio orçamentário estadual, além disso, os parcos impostos coletados acabavam sendo monopolizados por São Bento do Sapucaí, sede da comarca.

A escassez de verbas próprias fazia com que o reduto dos tísicos não dispusesse de serviços gratuitos de socorro aos fimatosos, a não ser a malfadada Liga de Assistência aos Tuberculosos Desamparados que, fundada em 1922 pelo médico consuntivo Raphael de Paula Souza, parece que nunca chegou a prestar socorro a qualquer enfermo, sob a alegação de falta de recursos. Ao encerrar sua existência em 1928, essa Liga doou o prédio de sua sede para o governo estadual, sob a promessa de que lá seria instalado um centro de atendimento aos pectários carentes. Assim surgiu, no ano de 1928, o primeiro Posto de Higiene jordanense. 
Os primeiros prefeitos sanitários de Campos do Jordão tiveram de lutar contra toda sorte de adversidades: ruas esburacadas, pântanos insalubres, ausência de serviços de saneamento básico nas áreas pobres e mais populosas coadunavam-se com a proliferação de pensões e restaurantes anti-higiênicos e de barracões construídos às pressas e alugados a preços altos, além das abusivas quantias exigidas pelos comerciantes para as roupas e alimentos indispensáveis aos forasteiros que peregrinavam pela região.

A estratégia paliativa para contornar a falta de recursos públicos foi a criação de uma série de impostos locais que, ao serem somados, revelavam-se pouco significativos, cobrindo apenas os gastos representados pelos salários de meia dúzia de funcionários contratados pela prefeitura sanitária.

A década de 30 foi marcada por sucessivas inaugurações de sanatórios na Serra da Mantiqueira, fenômeno estimulado pela Companhia Campos do Jordão que, desde a qualificação oficial da prefeitura sanitária, assumiu a política de doar terrenos a todas as entidades que apresentassem projetos para a construção de casas de saúde nas montanhas. A dificuldade de manter a imagem turística da região determinou que a empresa de Macedo Soares redefinisse seus objetivos, comandando o processo de ocupação espacial jordanense e, em continuidade, estabelecendo as áreas reservadas ao funcionamento dos hospitais e pensões para enfermos e os lotes que deveriam ser de uso exclusivo dos turistas.

Com isso, no ano de 1930, foram ativados os Sanatórios Divina Providência e São Paulo, desdobrando-se pouco depois na entrada em funcionamento do Sanatório e Preventório Santa Clara, do Sanatório Santa Cruz e dos Sanatorinhos. Até o final da década, iriam existir dez nosocômios em atividade no município dos infectados, perfazendo o total de 652 leitos especializados. Apesar da discordância dos censos realizados naquele período, é certo que o número de vagas hospitalares para tuberculosos existentes em Campos do Jordão representava quase a metade das disponíveis em todo o estado de São Paulo, sendo que aproximadamente 50\% da hospedagem nosocomial jordanense estava reservada para a clientela pagante (Grieco, 1939).

A instalação de leitos para as vítimas da Peste Branca e o afluxo de médicos para Campos do Jordão resultaram na intensificação da procura da estância de cura pelos tuberculosos, transformando a ‘cidade enferma’ em uma estranha e contraditória comunidade, bem diferente daquela apresentada nos folhetos turísticos e na maior parte dos textos educadores assinados pela mão hipocrática.

A localidade via seus problemas se potencializarem, transformando-se em cenário de episódios chocantes. Os enfermos afluíam em massa, esperando encontrar com facilidade acolhida sanatorial, ou pensando que apenas a presença no ambiente serrano fosse o suficiente para recuperar a saúde comprometida. O custo de vida elevou-se ainda mais no decorrer dos anos 30 e o acúmulo de infectados pobres fez proliferar as choupanas e as pensões clandestinas.

O perigo sanitário dava mãos à possível ameaça da ordem pública. A polícia getulista começou a divulgar informações sobre a presença de perigosos 'inimigos da pátria’ na região, os quais faziam fortuna inclusive por meio da exploração do desespero dos enfermos e da solidariedade dos sadios. 
Alguns dos criminosos eram denunciados publicamente, como aconteceu com um certo Itagyba Ribeiro Barra que, sob o nobre pretexto de angariar verbas para a construção de um sanatório para os fimatosos pobres, mobilizou esforços sensibilizadores da elite nacional, para que esta oferecesse doações para a causa assistencialista. Tendo sucesso nas suas primeiras investidas, Ribeiro Barra chegou mesmo a enviar telegramas para Hitler e Mussolini, tentando com isso aumentar ainda mais o escopo de seu golpe (Paulo Filho, 1986).

Fruto do pouco interesse ou incapacidade estatal em criar formas planejadas de socorro aos enfermos nos primeiros anos de vida da prefeitura sanitária e do aproveitamento irregular das doações caritativas, Campos do Jordão converteu-se em ambiente lúgubre e assustador, testemunhando cenas que evocariam a pena de Dante.

Segundo o depoimento de Raphael de Paula Souza - que no final da década de 40 assumiria a direção do Serviço Nacional de Tuberculose e a primeira cátedra de tisiologia da Universidade de São Paulo - era comum se observar a morte pública de doentes, sendo que o consuntivo esvaía-se em sangue, sem que ninguém se prontificasse em socorrê-lo.

O professor Paula Souza, no momento em que a cidade lhe prestou homenagem pela ação pioneira no socorro aos infectados pobres, lembrou ainda:

O primeiro sanatório de Campos do Jordão foram os bancos da estação ferroviária de vila Abernéssia, e o primeiro serviço social foi realizado pelo agente da estação, Sebastião Leitão. Apesar de violento e malcriado, João Maquinista foi um benemérito; tinha uma serraria na atual Av. Januário Miráglia, à altura do $n^{\circ} 909$, e aquele pessoal, semi-vivo, que ficava na estação ferroviária, era levado para a serraria de João Maquinista, vomitando sangue (hemoptise), esperando a hora de morrer. Até caixão já tinha pronto... (Paula Souza apud Paulo Filho, 1986:255)

Por sua vez, o advogado jordanense Pedro Paulo Filho, ao lembrar-se de sua experiência de menino em Campos do Jordão, complementou as trágicas informações sobre as cenas que feriam o cotidiano da estação de cura: "Sebastião Gomes Leitão, o agente, corria para lá e para cá, arrumando lugares para uns e passagens para outros. João Maquinista muito ajudou, cedendo a sua serraria, onde o doente durava 2 ou 3 dias, às vezes, uma noite...” (Paulo Filho, 1986:294).

O estado caótico em que se encontrava a cidade das montanhas impôs intervenção oficial mais rigorosa sobre a legião de pectários que dominava o ambiente jordanense. A primeira operação administrativa foi instalar no cargo de prefeito apenas clínicos com conhecimentos de higiene pública, afastando assim os primeiros administradores da região que pertenciam à clientela dos coronéis atuantes no Vale do Paraíba ou que alinhavam-se dentre os burocratas de carreira e que gozavam de algum prestígio junto ao partido governista.

Com esta medida, a partir de 1931, foi indicado para ocupar o cargo de prefeito sanitário o médico Antonio Gavião Gonzaga que estabeleceu o zoneamento da área como primeiro ato de sua administração. Seguindo as orientações estipuladas pela Companhia Campos do Jordão, o novo prefeito - que se manteve no cargo até meados 
de 1938 - ratificou os limites do território que deveria ser exclusivo dos sadios e os terrenos destinados à construção de sanatórios, assim como exigiu o imediato cadastramento de todos os habitantes da estação de cura, procurando saber quem e quantos eram os pectários que residiam na estância climatoterápica.

Em maio de 1933, Campos do Jordão recebeu autonomia política, desvinculandose de São Bento do Sapucaí. A mesma lei que criou o município, estabeleceu também o código orientador da edificação de sanatórios, hospitais gerais e pensões, além de reforçar a vigilância higienista sobre os enfermos. Com isso, buscava-se controlar eficientemente a presença dos infectados na cidade, ditando regras arquitetônicas e comportamentais que objetivavam inibir a disseminação da moléstia pulmonar entre os habitantes e os turistas sadios que percorriam a região.

A administração jordanense aprovou leis e decretos que impunham a distância mínima de dez metros entre os prédios a serem construídos no município, a obrigatoriedade de todos os edifícios de trânsito coletivo terem escarradeiras e os bares, restaurantes e pensões disporem de equipamentos destinados à esterilização de pratos, copos e talheres. Mais ainda, todos os habitantes e turistas que chegassem à serra deveriam submeter-se ao exame dos pulmões, sendo que os tuberculosos não poderiam receber abrigo nos hotéis destinados aos sadios, além de assumirem o compromisso de portar escarradeiras de bolso, apresentando-as aos inspetores sanitários sempre que assim fosse solicitado.

Completando estas medidas, ainda coube ao Dr. Gavião Gonzaga conseguir junto à administração estadual a instalação de órgãos públicos que direta ou indiretamente favoreciam a fiscalização da vida pública e privada dos moradores da prefeitura sanitária, tais como novos Postos de Saúde (a partir da reforma de 1938 liderados por um Centro de Saúde), delegacia e subdelegacias de polícia e escolas de ensino elementar.

No transcorrer do terceiro ano de sua gestão na prefeitura, o Dr. Gavião Gonzaga reclamou do estado desolador que marcava a estação de cura, apesar de todas as medidas que havia tomado desde o momento de sua posse. Segundo este médico, tudo faltava para que Campos do Jordão se tornasse uma verdadeira prefeitura sanitária, desde um plano urbanístico próprio e desvinculado dos interesses dos grandes proprietários de gleba até um órgão coordenador dos serviços médicos oferecidos localmente, acrescentando ainda que as prescrições sanitárias eram anemicamente obedecidas pela população das montanhas.

O ambiente consuntivo foi denunciado como uma grave ameaça à saúde dos incautos turistas e mesmo dos pectários, inclusive devido ao funcionamento de inúmeros sanatórios e pensões clandestinas que trocavam precárias acomodações e assistência clínica de péssima qualidade pelo pouco de dinheiro que os tísicos com acanhadas posses poderiam dispor (Gonzaga, 1935).

No mesmo documento, o prefeito declarou que o principal motivo da 'anarchia' imperante nas montanhas era a inexistência de um orçamento especial destinado ao município dos infectados. Mesmo que estabelecida pela lei datada de 1926, até o ano de 1934 a estação de cura não tinha recebido uma dotação orçamentária suficiente para a realização dos compromissos básicos com a saúde pública local, resultando no ambien- 
te malsão e perigoso que imperava em Campos do Jordão. Afinal, concluiu o médico em seu relatório revelador: "é incrível que, em São Paulo, se crie uma Prefeitura Sanitaria sem os recursos sanitarios” (Gonzaga, 1935:66).

Como resultado do veemente documento preparado pelo prefeito, o governo estadual nomeou o engenheiro Prestes Maia para chefiar uma comissão composta por médicos e urbanistas que deveria elaborar um projeto oficial de regramento do uso do espaço jordanense. A demora na conclusão do plano fez com que este só fosse apresentado ao Dr. Gavião Gonzaga nos últimos dias de sua presença à frente da prefeitura sanitária, sendo que, ao final das contas, o projeto assinado por Prestes Maia nunca chegou a ser colocado em prática.

Em conseqüência da inoperância oficial, abriram-se as portas para que a Companhia Campos do Jordão mantivesse o monopólio das decisões sobre a estância climática por mais alguns anos. A empresa liderada por Macedo Soares, assessorada por outras entidades menores, reunia poder suficiente para resolver inclusive sobre o local de construção e o estilo arquitetônico dos prédios sanatoriais, os quais pouco seguiam as normas sancionadas pela engenharia sanitária paulista.

A ingerência da Companhia Campos do Jordão nos negócios do município ganhava contornos denunciadores. Como árbitro dos confrontos que agitavam a vida local, Macedo Soares reunia maiores poderes deliberativos que o próprio prefeito. Como exemplo, tem-se a disputa instaurada entre os sanatórios Santa Clara e São Cristóvão, construídos em terrenos contíguos.

No ano de 1933, o nosocômio Santa Clara moveu ação contra a Sociedade Beneficente dos Chauffeurs do Estado de São Paulo, que já havia empenhado uma razoável quantia de dinheiro na edificação das estruturas do prédio do Sanatório São Cristóvão. O motivo do confronto entre as duas instituições revelava os contornos de classe: as irmãs missionárias que dirigiam as atividades do Sanatório Santa Clara recebiam quase que exclusivamente pacientes ricos e concluíram que o contato com uma 'má vizinhança' - representada pelos motoristas e seus dependentes - seria prejudicial para a saúde de seus requintados hóspedes.

Ciente do confronto, José Carlos Macedo Soares buscou abafar a situação, pagando uma alta indenização à Sociedade dos Chauffeurs para que abandonasse o prédio que estava sendo construído para abrigar os tuberculosos pobres. Além disso, a Companhia Campos do Jordão doou aos motoristas um novo terreno para a construção do hospital, distanciado vários quilômetros do religioso nosocômio dedicado à Santa Clara. Encerrava-se assim o conflito cuja motivação reproduzia a lógica geral que dominava o funcionamento da sociedade brasileira.

Neste contexto de planejamento público quase inexistente, crescia o número de enfermos que se instalavam na Serra da Mantiqueira. Apesar do Serviço Sanitário encaminhar alguns tuberculosos pobres para os sanatórios agraciados com subvenções governamentais, o número de fimatosos miseráveis e desassistidos era muito maior do que o contingente hospitalizado. Em continuidade, existia um exército de enfermos mendigos vagando pela cidade e que sobreviviam às custas de esmolas, do comércio ambulante e de pequenos furtos, engrossando a população das favelas que rapidamente iam ganhando forma na estação de cura. 
Visando a minimizar os efeitos da presença de tantos consuntivos desamparados no município, em 1935, o prefeito determinou a destruição de uma série de palhoças ocupadas pelos infectados pobres, ao mesmo tempo que adquiriu um barracão situado na periferia da cidade que, após algumas reformas, ganhou o nome de Abrigo de Emergência para os Tuberculosos. Neste local eram recolhidos os enfermos desabrigados, mantendo-se sempre lotado, com um número de hóspedes bem superior aos oitenta leitos disponíveis.

Complementando essa medida de segregação dos enfermos que tomavam as ruas jordanenses, no início de 1940, o interventor Adhemar de Barros sobrepôs-se à Companhia Campos do Jordão, impondo o poder público como único agente legalmente capacitado para definir as regras de convívio na 'cidade enferma'.

Nesse período foi aprovada uma lei estadual que, reiterando a orientação imposta por Macedo Soares, determinava que as vilas Jaguaribe e Capivari se constituiriam em áreas exclusivas para a acomodação dos turistas, enquanto a vila Abernéssia serviria de espaço aberto aos pectários. A mesma peça legal impunha que todas as pensões, hotéis e sanatórios que funcionavam nos terrenos residenciais teriam o prazo de um ano para serem transferidos para a vila dos infectados.

Na seqüência, o Departamento Estadual de Saúde reiterou a necessidade de cumprimento coletivo das disposições sanitárias, exigindo que todos os hotéis destinados ao acolhimento dos turistas deixassem de aceitar hóspedes consuntivos, cobrando rigorosa obediência ao dispositivo legal que impunha exame radiológico semanal aos visitantes, sendo que a perícia clínica deveria ser monitorada por um agente destacado pelo Centro de Saúde local.

Estas medidas, que com pequenas variações também foram aplicadas à estância de São José dos Campos, não impediram que os eventuais forasteiros sadios redobrassem as cautelas quando instados a percorrer o território das prefeituras sanitárias paulistas. O medo ao contágio kochiano aconselhava que se evitasse a permanência desnecessária nas cidades-sanatórios, pouco adiantando a multiplicação dos cartazes que, afixados nas portas de alguns hotéis e de lojas comerciais, tinham inscrito a invariável advertência: "é expressamente proibida a entrada de pessoas portadoras de moléstias infecto-contagiosas”.

Antigos moradores de Campos do Jordão e São José dos Campos lembram que era fato comum os passageiros dos trens que faziam paradas nas estações de cura se recusarem a sair da composição, e quando assim o faziam, muniam-se de precauções, levando um lenço ao nariz para evitar a invasão do mortal bacilo. O médico Eduardo Etzel (1987) rememorou que, durante os anos que trabalhou como cirurgião do Sanatório Vicentina Aranha, recobria-se de todos os cuidados para impedir o acidente da contaminação, não se arriscando nem mesmo a tomar um cafezinho nos bares joseenses, com medo de tornar-se mais uma vítima da Peste Branca.

A fama curativa das estâncias climatoterápicas amalgamou-se com a reputação de áreas insalubres, pois perpetuadoras da infecção kochiana. O município de Campos do Jordão despontava como a localidade brasileira com maior taxa de tuberculinização infantil. Segundo uma pesquisa datada de 1940 e realizada pelo Cen- 
tro de Saúde local, pouco mais de $70 \%$ das 429 crianças matriculadas nas escolas da área apresentavam reação positiva ao micróbio tuberculoso, sendo que 8 delas eram portadoras de lesões tísicas.

Mediante estas constatações, os autores do estudo concluíram que, se utilizassem métodos mais confiáveis, poderiam detectar uma porcentagem ainda mais elevada, atribuindo tal situação ao cotidiano que, apesar de todas as restrições sanitárias, acabava forçando a aproximação entre os tísicos e os sadios. Os mesmos estudiosos diagnosticaram: "a existência de uma certa promiscuidade entre os enfermos e o resto da população local, promiscuidade essa que se vem acentuando de ano para ano” (Faria, 1940).

Mais do que mutiplicadora dos tributários do Grande Mal em seus limites, as prefeituras sanitárias foram denunciadas como propagadoras da tuberculose pelas regiões vizinhas. A poluição microbiana ampliava seu raio de ação, atingindo as pequenas cidades e os bairros rurais do Vale do Paraíba. Tal fenômeno foi atribuído inclusive à prática comum dos sanatórios promoverem, periodicamente, excursões pelas áreas pouco distantes das estâncias climatoterápicas, facilitando o contato entre os doentes do peito e a população cabocla que, desconhecedora do bacilo de Koch, mostrava-se altamente suscetível à contaminação microbiana e ao rápido desenvolvimento da moléstia pulmonar.

Degradados, ameaçados, discriminados pelos sadios e quase esquecidos pela filantropia e pela administração pública: condicionantes impostas tanto aos tributários da Peste Branca quanto aos centros de convergência dos tuberculosos.

As dificuldades encontradas em permanecer residindo nas grandes áreas urbanas coagiam os pectários a trilharem as rotas que tinham ponto final nas cidades sanitárias, esperando nelas encontrar assistência e solidariedade. Chegando às estações de cura, os doentes do peito deparavam-se com novos e surpreendentes obstáculos, situação que se ampliava em escala inversa aos recursos econômicos disponíveis por cada um dos infectados. A geografia da esperança poderia, então, converter-se na geografia da desilusão.

\section{NOTAS}

1 Tanto os prontuários quantos as fichas médicas utilizadas neste estudo foram produzidas no âmbito do Hospital-Sanatório São Luiz Gonzaga, sendo doravante indicadas, respectivamente, pelas abreviações P. e F. 


\section{7 \\ Na Senda dos Tisiologistas}

Fixado o cenário geo-histórico das ilhas sanitárias, talvez ainda não seja o momento de retomar a trajetória de vida e de morte dos doentes do peito. Isto porque, antes de voltar aos personagens privilegiados da história social dos enfermos, torna-se necessário retocar a imagem dos atores secundários - mas não menos importantes que também emprestam tensão à trama orquestrada pela Peste Branca. Nesta cirurgia, o agrupamento médico, que até aqui apareceu sob o manto da entidade corporativa e dos debates doutrinários, merece destaque.

A combinação da perspectiva fincada no cotidiano público com o olhar que espreita a esfera da intimidade hipocrática favorece a pluralidade de questionamentos sobre as possibilidades e os limites clínicos e cirúrgicos de combate à moléstia pulmonar. Para além dos códigos de discrição e ética ensinados pela academia médica, revelam-se, afinal, homens que, empenhados em curar e lucrar por meio deste trabalho, acumulavam alegrias e frustrações próprias daqueles que dispunham de estratégias e armas de alcance sempre duvidoso para duelar com um inimigo que parecia infinitamente mais poderoso.

\section{A Opç̃̃o Tisiológica}

Conhecer a motivação que conduzia o facultativo recém-graduado a optar pela 'perigosa' área da tisiologia consiste na primeira operação para o entendimento da vida do médico que, usualmente, repartia suas atividades entre a prática sanatorial e o consultório particular. Isso porque era moeda corrente nas décadas passadas como até hoje - a idéia de que o trabalho clínico-cirúrgico junto aos pacientes portadores de enfermidades infecto-contagiosas constituía-se em tarefa de risco considerável, podendo o profissional de saúde transformar-se em vítima da doença que buscava combater.

Além disso, a condição moralmente pervertida conectada à imagem dos consuntivos certamente se revelava em fator auxiliar de desencorajamento, fazendo o candidato à especialização hesitar e até desistir dos compromissos de aprimoramento neste setor da medicina. 
Uma análise precipitada permitiria concluir que a escolha pela tisiologia encontrava fundamentos exclusivos em um punhado de motivos perenemente recitados pela corporação dos esculápios. Nesse processo, o juramento misericordioso de prestar assistência aos enfermos mais graves se uniria aos desafios propostos por uma área frágil em conhecimentos e recursos salvadores; em contrapartida, o médico teria à sua disposição uma clientela cativa, sendo que pelo menos uma parte dos pacientes retribuiria prodigamente aos serviços prestados pelo facultativo.

As histórias de vida - conceito assumido neste livro de forma livre, independente das propostas indicadas pelos estudiosos desta técnica - de inúmeros especialistas em moléstias pulmonares fazem aflorar um dado comum que garante o caráter peculiar da comunidade dos tisiologistas: a maior parte dos doutores que se propuseram a combater o Grande Mal nutria convívio íntimo com a tuberculose, não apenas como agente sanitário, mas também como vítima imediata da infecção.

Aloysio de Paula, Raphael de Paula Souza, Rodolfo dos Santos Mascarenhas, Ruy Dória, Nelson D’Avila, Januário Miráglia, Clovis Correa, Miguel Covello Junior, João Pedro Além, Vicente Marcilio, Manoel Puerta Junior, Alberto Cavalcanti, Mario Capper Alves de Souza, José Feijó, Ivan de Souza Lopes e João Baptista de Souza Soares são alguns dos médicos que, atuantes nos anos 30 e 40, sofriam no próprio corpo os dolorosos efeitos do germe de Koch.

Entre alguns discípulos de Hipócrates, tornou-se fato comum referências sobre o que era denominado 'minha tuberculose', especialmente quando os clínicos teciam mensagens orientadoras para os pacientes infectados. O tisiologista Alberto Cavalcanti foi um dos fimatosos que se arvorou em modelo a ser imitado por sua clientela e pelos leitores do seu livro de orientação aos pectários. Após discorrer sobre sua trajetória de fraco do pulmão, o Dr. Cavalcanti questionava seu público: “Lendo êste capítulo, escrito, com otimismo, por quem já conheceu de perto a tuberculose, como doente e como médico, participará o leitor dêste otimismo? Ou julgará mais acertado manter a dúvida e o pessimismo?” (1935:22).

Segundo os fragmentos autobiográficos registrados nos livros dirigidos aos enfermos leigos, o caminho percorrido pelos clínicos contaminados correspondia aos percursos corriqueiros a todos os consuntivos. Descoberto o estado infectado próximo ao encerramento do curso de medicina ou logo após o juramento exigido pela Academia, as alternativas vislumbradas para o encaminhamento da vida eram estreitas: abandonar a carreira médica ou internar-se em um sanatório, para, no recolhimento hospitalar, aprender minuciosamente a prática tisiológica e, ao mesmo tempo, tratar dos pulmões contaminados.

Entre uma e outra via, alguns médicos preferiram afastar-se da profissão, dirigindo-se para as montanhas exclusivamente para tentar a cura. Assim aconteceu com Jamil Almansur Haddad que, diagnosticado consuntivo em meados da década de 30, reuniu forças suficientes para completar o curso na Faculdade de Medicina de São Paulo, recebendo seu diploma em fins de 1938. Pertencente a uma família de ricos industriais e comerciantes, o Dr. Jamil recolheu-se em Campos do Jordão, preenchendo o tempo cobrado pelo tratamento com a produção de composições poéticas. Ao recuperar a 
saúde, o escritor retornou para a capital dos paulistas, dedicando-se à docência no Departamento de Letras da Universidade de São Paulo.

Contrariando a opção assumida por Almansur Haddad, outros esculápios preferiram dedicar-se ao tratamento de seus companheiros de enfermidade. Nessa condição, somavam-se elementos ambíguos em um único personagem, já que a liberdade normatizadora conferida aos tisiologistas pouco se afinava com o cerceamento imposto à clientela, tão contaminada quanto o próprio médico.

A trajetória do médico Manoel Puerta Junior (P. 1107) é um exemplo do encaminhamento existencial imposto aos clínicos fimatosos. Nascido em Jaboticabal, no ano de 1915, Puerta Junior foi enviado pelo pai - fazendeiro abonado - para graduar-se em medicina no Rio de Janeiro, regressando ao seu município de origem no verão de 1939.

Engajado nas tarefas de clínico geral e administrador dos negócios da família, em setembro do ano seguinte, o Dr. Manoel começou a padecer de fraqueza e tosse contínua, atribuindo tais sintomas ao agravamento da bronquite que o acompanhava desde a infância. Porém, “no dia 18 de novembro [de 1940] às 9 1/2 da manhã teve tosse com escarros hemoptoicos e diarrea” (P. 1107). Ato contínuo o doente consultou um colega de profissão, o qual concluiu “não ser nada pulmonar”. Desconfiado do diagnóstico apresentado, ainda no mesmo dia o enfermo submeteu-se a um exame radiológico, descobrindo então que seus pulmões estavam comprometidos pela tuberculose. Após um mês de tentativas de tratamento em domicílio e percebendo estar piorando, o pectário transferiu-se para a cidade de São Paulo, sendo encaminhado ao sanatório do Jaçanã pelo seu amigo, o tisiologista João Grieco.

O paciente permaneceu apenas três meses na casa de saúde paulistana. Acompanhando a tendência comum entre os internados no Hospital São Luiz Gonzaga, o médico infectado pediu alta, transferindo-se por conta própria para um nosocômio jordanense. A melhora pulmonar alcançada durante a estada na Serra da Mantiqueira permitiu que o Dr. Manoel voltasse a residir com seus pais, a partir dos fins de 1942. Mas, transcorridos seis meses desde o retorno para Jaboticabal, novamente o consuntivo bateu à porta do Sanatório do Jaçanã, informando ter sofrido recaída, sendo imediatamente submetido à intervenção cirúrgica (P. 3712).

No tempo que permaneceu em sua residência, é bem provável que o clínico tenha infectado seu pai, o espanhol Manoel Puerta (P. 2442). Isto porque, na primeira internação, o médico tuberculoso havia declarado que seus progenitores "gosavam de plena saude", sendo que, em fevereiro de 1945, o fazendeiro veio se juntar ao filho, apresentando uma tísica disseminada que o levaria a óbito nas primeiras horas do dia 12 de abril do mesmo ano, apenas quatro meses após sentir os primeiros sintomas produzidos pelo bacilo de Koch.

O trauma gerado pela morte paterna combinou-se com a piora do estado de saúde do médico fimatoso, fazendo o Dr. Puerta Jr. manter-se no hospital filantrópico por mais de três anos consecutivos. A anotação prontuarial do nome do paciente antecedido pelo título acadêmico que lhe havia sido conferido pela escola médica carioca revelava-se como o reconhecimento grupal do status diferenciado do enfermo, originando uma situação atípica e constrangedora, em que inevitavelmente se defrontavam 
forças contraditórias. Por óbvio, os funcionários do sanatório tendiam a repetir a conduta padrão frente aos hóspedes tuberculosos, enquanto o grau de doutor e a riqueza familiar levavam este consuntivo a não ser identificado integralmente aos demais enfermos do isolamento sanitário.

Frente a este dilema, a tendência dos sanatórios era integrar os eventuais pacientes titulados como membros secundários das equipes médicas. A partir do mesmo ano em que se iniciou o segundo internamento do clínico consuntivo, o nome do Dr. Puerta Jr. passou a constar da lista de facultativos que atuavam no Hospital do Jaçanã, o que lhe abriu oportunidade para ganhar reputação, inclusive como autor de inúmeros estudos sobre as técnicas empregadas nas cirurgias torácicas. A experiência íntima com a tuberculose transformara o clínico em tisiologista.

Não só o contágio na primeira pessoa levava os estudantes de medicina a optarem pela especialização pulmonar. A presença mortífera da Peste Branca na órbita doméstica também se impunha como elemento incitador no instante decisivo do destino profissional.

Eduardo Etzel - que uniu as atividades de tisiocirurgião em São Paulo e em São José dos Campos com o posto de catedrático da Faculdade de Medicina da Universidade de São Paulo -, ao fazer a avaliação de sua trajetória de vida, parece que não teve dúvidas ao afirmar que seu encaminhamento para a tisiologia deveu-se muito à morte de Roberto, irmão mais velho e rival, cuja existência foi ceifada pela enfermidade pulmonar:

No meu inconsciente a morte de meu irmão foi a concretização do meu ódio contra o esbulho do amor materno. Ódio desperta culpa pela imaginária destruição do irmão, resultando a defesa psicológica que conduz a variadas atitudes na vida real. (...) A mencionada curiosidade infantil obsessiva e a culpa pela doença e morte de Roberto teriam suas compensações no exercício da profissão: tornei-me um pesquisador em todos os ramos da medicina por que passei $e$ logicamente um especialista no tratamento da tuberculose. (Etzel, 1987:34)

\section{Na Trilha da Precariedade}

A escolha pela tisiologia colocava o médico iniciante em contato com uma realidade que o surpreendia, principalmente porque o arsenal clínico-cirúrgico disponível pela especialidade padecia de lacunas bem maiores que outros ramos da medicina. Tal averiguação contrastava com os discursos oficiais, pois as falas corporativas no Brasil, reproduzindo o tom ufanista de Vargas, insistiam em afirmar para o público leigo que a tisiologia estava plenamente capacitada para tratar e curar os consuntivos cuja enfermidade ainda não tivesse assumido decurso agudo.

Neste idealizado contexto, os graduandos de medicina abandonavam os bancos universitários tendo parcas noções sobre as características e o funcionamento da tuberculose, esperando encontrar no ambiente sanatorial conhecimento e condições materiais apropriadas para cumprir a tarefa de assistência aos infectados. 
No entanto, os relatórios assinados pelos diretores clínicos de várias casas de saúde deixavam claro que os sanatórios padeciam da falta de quase tudo: médicos em número suficiente, harmonia e integração entre os funcionários, aparelhos de Raios X, instrumentos em condições de uso, mesas cirúrgicas, microscópios, cobaias, camas hospitalares, escarradeiras, urinóis e roupas para os enfermos eram alguns dos itens constantemente mencionados. Mais ainda, um antigo funcionário de um sanatório filantrópico confidenciou que, durante os anos marcados pela Segunda Guerra Mundial, chegou a escassear até mesmo alimentação, impondo o racionamento da comida que era servida aos albergados.

A postura defensiva dos administradores hospitalares, fugindo à lógica, avaliava que as limitações das atividades sanatoriais deviam-se basicamente à formação precária e à falta de empenho dos profissionais da saúde. Por isso, os tisiologistas eram colocados sob suspeição, tornando-se regra as avaliações que responsabilizavam os médicos e seus auxiliares diretos pelas altas taxas de acidentes cirúrgicos e de mortalidade que imperavam nos nosocômios que assistiam os consuntivos (Paula, 1949).

Destituídos de amparos institucionais favoráveis, os facultativos interessados em aprofundar seus conhecimentos também não encontravam o incentivo dos braços governamentais, tornando a tisiologia nacional isolada e defasada em relação àquela praticada nos centros médicos estrangeiros. Para fugir a este dilema e também para se afastar das disputas por postos acadêmicos que agitavam os sanatórios com ligações universitárias, muitos médicos tentaram obter bolsas de estudo no exterior, onde os facultativos tuberculosos poderiam inclusive consultar os líderes mundiais da especialidade.

Seguindo a estratégia de buscar aperfeiçoamento em outros países, Eduardo Etzel foi premiado com o auxílio da Fundação Guggenheim para seguir os cursos ministrados no Centro Hospitalar de Ann Arbor, vinculado à Universidade de Michigan. Nos Estados Unidos, o Dr. Etzel permaneceu durante os anos de 1940 e 1941, revelando sua perplexidade frente às técnicas empregadas pelos norte-americanos:

Quando cheguei [ao hospital americano] já era, bem ou mal, um cirurgião tanto quanto possível completo. (...) Mas o que vi estarreceu-me e me fez pensar que estava num outro mundo. (...) Tudo me espantava. Soro na veia durante o ato operatório e sangue também se necessário. Operações lentas, sem pressa e com um respeito quase religioso à integridade do paciente. Contagem das gazes e compressas utilizadas, a fim de evitar esquecimento. Aspiração para retirada de sangue no campo operatório, sutura com fio de algodão por mim desconhecido, enfim, tudo novo, melhor e diferente. (Etzel, 1987:131)

Pode-se supor que os olhos do bolsista estivessem contaminados pela ideologia norte-americana que, durante a Segunda Guerra Mundial, intensificou a campanha divulgadora dos Estados Unidos como a nação do progresso e da sofisticação científica. Mas não eram só os ‘irmãos do norte’ que impressionavam o Dr. Etzel. De regresso ao Brasil, o tisiocirurgião foi convidado a proferir uma série de conferências na Argentina, mostrandose novamente irrequieto com a baixa qualidade da medicina praticada na sua pátria:

Lá chegando e observando os serviços de cirurgia de alguns hospitais, tive, só então, o choque profundo de ver o atraso do Brasil em cirurgia. Encontrava na 
Argentina um ambiente equivalente ao que tanto me havia surpreendido nos Estados Unidos. (...) [No Brasil] tudo era adverso, nossa enfermagem era selvagem, representada antes pelo avental branco do que pelo conhecimento. (1987:135)

Frente a todas estas limitações, a tisiologia nacional mostrava-se constrangedoramente precária no cenário de uma especialidade por si mesma repleta de críticas lacunas. A possibilidade de obtenção de melhora ou de cura dos pectários era ainda mais reduzida que em outros países, mesmo se o paciente pagasse regiamente pela assistência médica recebida.

Quanto aos clínicos, estes se perdiam frente à multiplicidade de especulações terapêuticas, fomentadas tanto no Brasil quanto no estrangeiro. Com as dúvidas que foram se acumulando em torno da eficiência do tratamento com base no 'clima de altitude’, os tisiologistas voltaram-se para a verificação da potencialidade das drogas apresentadas como curativas dos pulmões infectados.

Um levantamento realizado a partir das propagandas estampadas nas páginas do periódico paulista da especialidade permite saber que, no decênio iniciado em 1935, não menos de duas centenas de medicamentos foram recomendados como de 'eficiência incontestada’ na recuperação dos tuberculosos. Entretanto, a constatação de que nenhum dos preparados contribuía decisivamente para o restabelecimento da saúde dos pectários coagiu boa parte da comunidade médica a assumir ‘intra-muros’ que, na impossibilidade de curar os fimatosos, os médicos deveriam se resignar ao emprego de estratégias que, pelo menos, pudessem garantir maior tempo de vida aos infectados.

Como regra, a terapêutica sanatorial assentava-se no repouso contínuo e prolongado e no regime higieno-dietético, os quais eram combinados com aplicações de injeções de cálcio e de sais de ouro. Caso estas prescrições surtissem pouco resultado, o passo seguinte era combinar o tratamento inicial com a solução colapsoterápica. Neste encaminhamento, o pneumotórax artificial ganhou larga aceitação a partir da década de 30, consistindo na injeção de misturas gasosas na cavidade pleural do enfermo. Com isso, a medicina acreditava ter possibilidade de controlar o processo infeccioso, por meio do isolamento do órgão doente em relação à parede torácica.

Na situação em que ocorria a impossibilidade da instalação ou manutenção do pneumotórax, a alternativa seguinte consistia na intervenção cirúrgica para forçosamente colocar em repouso o pulmão comprometido. Apesar da máxima que ensinava que 'a tuberculose não gosta de bisturi', a tisiocirurgia ganhou o apoio de um grande número de especialistas, granjeando fama para o Sanatório do Jaçanã que, desde a sua fundação, deu ênfase ao tratamento operatório dos tuberculosos.

Em um período no qual a medicina ainda não reunia conhecimentos suficientes para a excisão parcial ou total de um dos pulmões - a pneumectomia só seria tentada no Brasil após 1945 - a colapsoterapia cirúrgica ajustou-se como um dos principais artifícios para interromper o processo infeccioso pulmonar. Apesar da variedade de linhas operatórias, duas intervenções ganharam aceitação generalizada, uma visando aos nervos frênicos, e outra às costelas.

A frenicectomia consiste na secção de um dos nervos frênicos na porção retroclavicular, podendo em certos casos derivar para o total esmagamento da peça. O 
objetivo desta operação era levar à paralisação e à conseqüente ascensão da metade correspondente do diafragma, resultando no interrompimento da atividade respiratória do pulmão adoentando, fato que favorecia o retrocesso das cavernas pulmonares.

Na seqüência dos atos cirúrgicos, o pectário poderia também ser submetido à toracoplastia, cirurgia mutilante que se realizava por meio da ressecção de três a cinco costelas, levando o pulmão infectado a ganhar relativa liberdade do arcabouço torácico. Nesta alternativa, a intervenção era extremamente dolorosa, sendo realizada em pelo menos dois momentos distintos. Como resultado, o tuberculoso guardava pelo resto dos seus dias a marca externa da cirurgia, pois a toracoplastia tinha como subproduto a deformação do tórax e o desvio da coluna vertebral, abrindo chances para que o doente ficasse corcunda.

O risco implícito das operações pulmonares ganhava novo peso quando se constata que a avaliação do Dr. Etzel sobre o procedimento cirúrgico nacional não estava afastada da verdade. Anotações sobre a ocorrência de acidentes causados pelo despreparo da equipe médica é uma presença constante nos prontuários do Hospital do Jaçanã.

Dentre tantos casos assinalados, destaca-se o da carioca Iracema de Almeida (P.3617) que, depois de permanecer quase uma década internada no jordanense Sanatório Divina Providência, em maio de 1943 foi encaminhada para o Hospital São Luiz Gonzaga para se submeter à toracoplastia. Realizado os 'dois tempos' operatórios, a paciente retornou para a Serra da Mantiqueira, mas pouco depois voltou à casa de saúde paulistana a fim de, mediante nova cirurgia, permitir a "retirada de uma gaze esquecida pelo Dr. Freitas”.

Mesmo quando o trabalho cirúrgico se desenvolvia sem acidentes imediatos, eram grandes as chances da ocorrência de complicações nos dias subseqüentes à operação. O grupo paulista de médicos tisiólogos agregados ao Sanatório do Jaçanã foi o único que divulgou informações sobre o assunto, mesmo assim, limitando suas observações ao estudo das estatísticas referentes à 'operação de Jacobaeus', ato relativamente simples e que consistia no secionamento das aderências pleurais que impediam a realização do pneumotórax.

Nestes casos, os dados revelam que, no ano de 1936, cerca de $40 \%$ dos enfermos submetidos a este tipo de intervenção apresentaram complicações pós-cirúrgicas, enquanto quatro anos depois a mesma taxa se elevava para 77\%. Em ambos os momentos, a explicação fornecida pela equipe médica era única: "a gravidade das lesões tuberculosas" (Nebias, 1937).

O poderio da enfermidade parecia colossal frente aos tênues recursos disponíveis pela clínica e pela cirurgia, resultando no ritmo intenso de óbitos ocorridos no isolamento. A quantificação dos dados registrados nas 3.438 fichas de pacientes internados no Hospital São Luiz Gonzaga entre os anos de 1932 e 1945 permite concluir que 62\% dos pectários encontraram a morte nas enfermarias do nosocômio, ressaltando-se que a taxa de mortalidade chegou a 75\% nos primeiros anos de funcionamento do sanatório. Índice parecido foi indicado pelo Dr. Alves Corrêa (1949) que, ao verificar a história clínica de mil tuberculosos assistidos pela casa de saúde do Jaçanã desde sua inauguração, concluiu que 65,9\% do grupo estudado teve a morte como desfecho do internamento. 
Como reagiam os médicos operadores em um contexto em que as dores indizíveis experimentadas pelos pacientes encontravam como resposta a grande probabilidade do fatal fracasso das violentas intervenções cirúrgicas? Neste ambiente, o discurso enganoso que pontificava a capacidade da medicina em recuperar a saúde dos tuberculosos ganhava uma funcionalidade surpreendente. Sim, mentir para si próprio e impor a fantasia ao paciente consistia em arma única utilizada pelos cirurgiões para transpor os momentos críticos vivenciados nas salas de operação.

Ainda são as confidências do Dr. Etzel que revelam a agonia e as palavras mentirosas que povoavam os instantes de desespero:

No final da década de 30, o cirurgião do tórax usava anestesia local com novocaína. A toracoplastia já era feita em vários tempos operatórios com intervalos de 20 a 30 dias. No primeiro tempo, com os tecidos normais, a anestesia local era perfeita, tudo correndo sem maiores sofrimentos. Mas nos tempos subseqüentes, com tecido edemaciado e já com reações fibróticas, a difusão do anestésico era precaríssima, transcorrendo a operação com grandes sofrimentos do paciente.

Era uma luta amarga e cínica entre o cirurgião que dizia para ter paciência, que era apenas sensação de tato e não de dor, e o pobre infeliz que gemia com toda razão do mundo. Caricaturando, seria como dizer ao paciente 'você pensa que dói, mas não dói'. Mas a operação tinha que ser feita, pois a anestesia geral pelo éter, em caso de doença pulmonar, estava fora de cogitação. Era operar e tentar a cura ou deixar morrer pela progressão da doença. (Etzel, 1987:127)

A estratégia do engodo não era exclusividade do operador catedrático do Hospital do Jaçanã, que não se fazia de rogado para ensinar o uso da mentira aos seus pares. As lições de fantasia foram aprendidas inclusive por um quintanista de medicina, que em 1935 foi escalado para estagiar no sanatório paulistano da Santa Casa. Meio século depois de servir como auxiliar do Dr. Etzel, o antigo residente de cirurgia confidenciou que, ao proceder a abertura do tórax de um paciente, fingia estar exercitando sua arte no cadáver de uma cobaia qualquer, tal como um coelho ou um cachorro. $\mathrm{O}$ nome do ajudante de 1935: Dr. Euryclides de Jesus Zerbini.

\section{a Percepção Clí́nica do Paciente}

Da mesma forma que a Peste Branca, o ensino dos códigos que regiam a relação entre o facultativo e sua clientela constituía-se em tópico que parecia despertar pouco interesse nas academias brasileiras. Na Faculdade de Medicina da Universidade de São Paulo, por exemplo, o professor Flaminio Fávero reservava uma aula de apenas 50 minutos para apresentar o tema aos sextanistas do curso, indicando como bibliografia de apoio à sua preleção um livro de sua autoria, no qual nenhuma linha era gasta para explorar as condicionantes do encontro entre o profissional da saúde e sua clientela.

Nesta situação, outras disciplinas da mesma escola empenhavam-se em preencher a lacuna aberta pelo mestre de deontologia médica. O professor Antonio de Almeida Prado, responsável pelo ensino de clínica, era um dos docentes que buscava chamar a 
atenção dos seus discípulos, levando-os às enfermarias da Santa Casa para ensinarlhes os princípios regentes da anamnese.

Como atividade prática de seu curso, em setembro de 1933, o Dr. Almeida Prado convocou os alunos do quarto ano para visitarem o Sanatório do Jaçanã, já que o tópico estudado naquele período versava sobre o exame dos indivíduos afetados pelas patologias respiratórias. Como material de estudo, o professor selecionou o caso do paciente José Candiá (P. 92), um daqueles tuberculosos que, apesar de fugir do comum biográfico dos tísicos, a medicina situava como o típico doente pulmonar e por isto objeto de fácil explanação pedagógica.

José Candiá era um sitiante sorocabano de 43 anos que dera entrada no Hospital São Luiz Gonzaga no mês anterior. Após informar que o pectário sofria de tísica terminal, o catedrático definiu o doente como homem de "vida promiscua, alcoolatra, fumante inveterado e siphylitico”. Em seguida, o Dr. Almeida Prado chamou a atenção dos estudantes para os principais pontos da história clínica do consuntivo, consultando as informações que anotara numa folha de caderno que foi preservada junto ao prontuário analisado:

Em plena saude começou a sentir-se fraco, fraqueza que augmentou rapidamente, a ponto de deixar completamente o serviço em 2 dias, perdendo todas as plantações. Tinha pouca tosse com expectoração amarela. Foi carregado para S. José onde Dr. Ivan o examinou. (...) O medico receitou e melhorou muito. Foi a Guararema, trabalhar em balcão, mas tornou a vida irregular, passando noitadas em jogos, bebidas e mulheres. Foi atacado então de tosse muito extensa, com abundante escarros, escarrando um dia laivos de sangue. Começou então a sentir febre a tarde um arrepio e dor de cabeça. Suores abundantes e emagrecimento rapido. (P. 92)

A apresentação inicial do tuberculoso como indivíduo marcado pela promiscuidade chamou a atenção dos aprendizes dos segredos da clínica. O termo em questão era a chave para o entendimento hipocrático dos tísicos, sendo palavra de emprego corrente nos ensaios especializados.

A necessidade de conferir contornos inteligíveis ao evento patológico e à existência enferma impôs que o Dr. Almeida Prado, imitando seus pares, lançasse mão das fórmulas concordantes com a tradição cultural que identificava a posição de doente do peito como desdobramento 'natural' da existência 'desregrada'. Segundo esta concatenação de idéias, a vida tuberculosa comportava uma variedade de 'máculas', estando dentre elas: dependência do álcool, do tabaco e dos tóxicos, parentesco próximo a pessoas enfermas, homossexualismo, onanismo, fruto de união consensual, deficiência mental, crença na doutrina espírita, criminalidade, 'tendências revolucionárias', condição de migrante e de morador em residência coletiva, enfim, todos os 'desajustes' que contradiziam as regras de sociabilidade formalmente ostentadas pela burguesia.

Somadas todas estas categorias 'aberrantes', revelava-se o que a comunidade médica definiu como sendo a 'psicologia dos tuberculosos'. Fenômeno de abrangência universal, a concepção de um padrão comportamental exclusivo dos infectados incitou os tisiologistas brasileiros a descobrirem os meandros da personalidade fimatosa por meio da consulta aos estudos estrangeiros, detendo-se principalmente nos textos as- 
sinados pelos italianos Bergolli e Sartori (1933). Estes pesquisadores, por sua vez, declaradamente fundamentavam suas observações nos enredos literários, rememorando os ensinamentos de Dumas Filho, dos Goncourt e de muitos outros ficcionistas para, no final de tudo, reiterarem a periculosidade moral e biológica dos consuntivos. Com isto perfazia-se o círculo vicioso que, preso nas armadilhas das composições romanceadas, ampliava o afastamento da medicina em relação à vida concreta dos tributários do Grande Mal.

A proliferação de referências acerca da 'mentalidade consuntiva' empolgou alguns médicos brasileiros a imitarem os seus pares europeus, resultando em textos que tinham como objetivo interpretar as 'atitudes' produzidas pela infecção kochiana. No ano de 1931, por exemplo, o Dr. Irineu Malagueta, médico carioca do Hospital São Sebastião, declarou que a moléstia pulmonar incitava seus tributários a desenvolverem 'espirito suspicaz' e 'sentimentos egoistas', dentre outras 'taras'.

Frente a estes eventos, o clínico prescreveu a intervenção reeducadora sobre os comportamentos afetados, aconselhando seus colegas de profissão a somarem paciência e sinceridade, indulgência e firmeza na tarefa de 'conversão moral' dos doentes do peito. Segundo o Dr. Malagueta (1931:86), pouco mais os tisiologistas poderiam fazer pelo 'bem-estar espiritual' de seus pacientes: "Fóra dahi, tudo sossobra na grande voragem, mas permanece christãmente, brilhando com a sua luz eterna, a bondade, a amenizar os ultimos momentos dos desgraçados, acenando sempre com as perspectivas illuminadas da esperança”.

O professor e administrador sanitário Aloysio de Paula talvez tenha sido o especialista que mais se empenhou em ratificar a máxima classificadora dos pectários como "os mais difíceis de todos os pacientes", avaliando os enfraquecidos do peito por meio dos jargões e manobras empregados pelo Estado Novo para desqualificar os grupos contestadores da política social varguista.

Ao dissertar sobre a 'psicologia consuntiva' para seus alunos da Faculdade de Medicina do Rio de Janeiro, parece que o Dr. Aloysio se esqueceu que poucos anos antes ele havia duelado contra o mal que escavara cavernas em seus pulmões, oferecendo o seguinte esclarecimento:

O fato é que o tuberculoso reclama assistência. É um doente que quer ser assistido e tratado. Nos indigentes e nos indivíduos de baixo nível social, as coisas se complicam porque a estas exigências se agregam situações de revolta e atitudes subversivas. É preciso nunca perder de vista estes fatos, porque frequentemente criam embaraços à própria administração pública. As cartas anônimas, as reclamações pela imprensa, as campanhas contra os estabelecimentos medicos e seu pessoal técnico são frutos desta mentalidade. Um exemplo de todo o dia é que passo a citar e que ilustra esta mentalidade. Quando um doente deseja ir para um hospital e não há vaga, frequentemente ele usa o seguinte recurso: deita-se à calçada do palácio do Governo e ali se converte numa vitima dos nossos estabelecimentos. Muito leito supranumerário já tivemos que colocar em nossos hospitais para doentes que, durante anos, desprezam todas as possibilidades de cura que nossos médicos lhes ofereciam com insistência e dedicação, mas que, quando no período final, tornaram-se já difíceis de se locomover, 
exigiam um leito de hospital para morrer, não se importando saber si tal leito não seria mais util a um doente recuperável e conciente (sic) dos seus deveres sanitários. (Paula, 1944:25)

Com estes norteamentos, os tisiologistas assumiam seus postos nos gabinetes clínicos, atendendo pacientes ricos ou pobres, brancos ou negros, arredios ou falantes, moribundos ou ainda com leves sintomas da infecção.

A leitura da documentação prontuarial sempre deixa a impressão que os médicos esforçavam-se antes de mais nada em descobrir os grandes mistérios da existência tísica, os quais necessariamente deveriam conter elementos que se afinavam com a categoria 'promiscuidade'. Nos momentos em que isto acontecia, os facultativos exploravam a informação ao máximo, registrando detalhes dos segredos íntimos confidenciados pelos tuberculosos com um afã tal que o leitor desavisado poderia supor serem dados despropositados e destituídos de interesse para o diagnóstico médico.

Assim aconteceu com o barbeiro bauruense de 28 anos chamado Celso de Souza Poletti (P.98), que deu entrada no Sanatório do Jaçanã em dezembro de 1933. Após concluir o questionamento identificador inicial, o esculápio descobriu que o tuberculoso “tinha luctado na revolta de 24, na coluna de Prestes e na Guerra de 32”, situação que exigiu do clínico o registro detalhado da participação do doente nos conflitos mencionados. Somados os elementos, o facultativo não teve dúvidas em classificar a personalidade do paciente: "hábitos revolucionários".

A mesma reação dominou a pena do médico que, em abril de 1935, atendeu o confeiteiro Rosendo Souza Dias (P. 318), de 41 anos. A partir do momento em que o clínico anotou que “de 5 annos para cá as glandulas mammarias começaram a si desenvolver e 'hoje parecem de moça'”, o interrogatório tomou o rumo averiguador da vida sexual do fimatoso, descobrindo entre outras coisas que "o doente sempre teve pouco interesse sexual”, “sofria de siphylis annal” e que "há 15 annos é impotente”.

Os registros de ‘aberrações’ pretensamente associadas ao estado tuberculoso fascinavam os clínicos, instruindo anotações prontuariais marcadas por crimes passionais, suicídios, incestos e brigas sangrentas. Em contato com pacientes que narravam histórias de “desregramento” e violência, os tisiologistas elaboravam relatórios tensos, tais como o que versou sobre a vendedora ambulante Leoncia Rosa Picirillo (P. 242), uma mulher de 32 anos que abandonou a sua residência no bairro paulistano da Freguezia do Ó para dar entrada no Hospital São Luiz Gonzaga, no mês de maio de 1936. Inquirida pelo clínico de plantão, a tísica contou sua história que foi anotada pelo médico nos seguintes termos:

Sofria de bronchite desde a infancia, porem desde maio de 1932, no puerperio de seu ultimo filho, a tosse peiorou e teve hemoptise (2 litros de sangue). Nesse periodo seu marido falleceu de accidente e a passiente foi morar com outro homem, que logo mostrou interesse de se relacionar com a filha da doente. Em julho de 1933 foi para Londrina, no Paraná. Aumentou de peso e força e quasi desapareceu o catarro. Voltou para S. Paulo em janeiro de 1934, tomando então injecções de Tisiocrysina e xaropes e ficou fraca da ideia e da memoria (sic). Em janeiro ultimo sofreu forte abalo em casa porque o marido matou a enteada e suicidou-se; desde aí recaiu, pois teve de ficar a noite na rua, ao lado de um fogão, onde vende pasteis. 
A descrição dramática repartiu o espaço do prontuário com as informações sobre as condições de saúde da paciente para que, no final, o raciocínio médico pudesse emitir a avaliação clínica da fimatosa. A sentença "hábitos promíscuos" foi inscrita na documentação institucional como resultado articulador da biografia individual e familiar da enferma com a tuberculose bilateral que roubava a vida da infeliz Leoncia Rosa.

A caracterização do doente como indivíduo socialmente pervertido favorecia a instrumentalização dos códigos que deveriam viger nos ambientes sanatoriais. Questionada a lógica do rígido regramento fomentado pelos hospitais especializados, os médicos tendiam a responder por meio de referências caricaturais e generalizadoras sobre a trajetória social e a 'psicologia' dos albergados, reafirmando a necessidade de controle intensivo das vidas infectadas.

Os pronunciamentos médicos que seguiam esta linha de entendimento davam novas dimensões às propostas alimentadas pela tisiofobia. Na década de 40 , o administrador de um sanatório jordanense idealizou um projeto sanatorial aterrorizante:

Pra mim, o regime sanatorial tinha de ser o seguinte: a pessôa que sofre desta moléstia deveria ser isolada de tudo e por tudo; tinha de ser celado numa cela como um cavalo de corrida. O sanatório deveria ser construido do seguinte modo: cada quarto teria, no fundo, as necessárias instalações sanitárias; mais no fundo haveria um corredor que levaria ao consultório médico. Quando chegasse, o doente entraria diretamente no consultório e, depois de examinado, passaria por esse corredor e iria para sua cela, onde ficaria completamente isolado. Na frente das celas haveria outro corredor que conduziria ao refeitório. Na hora da refeição, cada doente passaria por esse corredor, dirigindo-se para o refeitório; no corredor, duas ou três freiras estariam de vigilância, para evitar que êles se comunicassem, a fim de não haver qualquer 'diz-que-diz-que'. (Nogueira, 1945:104-105)

O afã de conhecer a intimidade dos consuntivos mostrava-se uma missão arriscada porque poderia conduzir o médico para o território do inesperado. A tarefa de ouvir sucessivas histórias trágicas freqüentemente levava os discípulos de Hipócrates a se afastarem da cirurgia coisificadora do paciente e da patologia. Nestas ocasiões, a 'objetividade científica' perdia força, revelando os laços de terna humanidade que faziam o profissional de saúde e o enfermo fundirem suas indignações e seus prantos.

Quando em um dia de maio de 1944 Maria de Lourdes Gomes (P. 2511), uma adolescente parda de 19 anos, 1,71m de altura e pesando 40 quilos sentou-se à frente da escrivaninha de um anônimo tisiologista, este provavelmente sentiu-se constrangido com a aparência depauperada da cliente.

Ao pedir informações sobre a vida da enferma, a quase-menina confidencioulhe sua história: durante seus 13 primeiros anos de vida, ela viveu sob a tutela do Juizado de Menores, sendo então ‘adotada’ por um casal residente na Vila Mariana, que a colocou em casa para servir como empregada doméstica. Há seis meses, Maria começou a tossir e a expelir escarro amarelo, fato que a 'patroa' considerou sem importância, mesmo depois que o escarro passou a vir acompanhado de laivos sangüíneos. Nem o aparecimento de forte febre ao entardecer, de suores noturnos, da rouquidão da voz e 
do emagrecimento acentuado fizeram a 'patroa' mudar de atitude, continuando a cobrar da empregada jornadas de trabalho que se estendiam por até 16 horas consecutivas.

Somente quando Maria começou a padecer de sucessivas crises de hemoptise foi que a 'patroa' levou a serviçal até o Instituto Clemente Ferreira, onde, além de diagnosticar a tuberculose, um especialista prescreveu a rápida transferência da doente para Campos do Jordão. Contrariando a recomendação, a 'patroa’ acompanhou a enferma até o bairro do Jaçanã, abandonando-a no portão de entrada do Hospital São Luiz Gonzaga.

Além da tragicidade dos acontecimentos, este relato clínico chama a atenção pelos indícios do horror e reprovação do médico em relação às atitudes tomadas pela 'mãe adotiva' da pectária, que chegaria a óbito três meses depois de contar a sua história. A palavra patroa foi repetida quatro vezes no documento hospitalar, sempre entre aspas e, mais do que isto, em letras garrafais e destoantes do resto da composição, deixando a sensação de que o facultativo, solidarizando-se com a paciente, condenava a desalmada moradora da Vila Mariana.

No encadeamento das angústias, os depoimentos de alguns tísicos sensibilizavam os clínicos interpelantes que, por um momento, pareciam rejeitar o perfil psicológico do consuntivo calcado no modelo que lhes havia sido ensinado na Faculdade de Medicina.

Em maio de 1945, o operário Mario Egydio Pereira (P. 4018), acometido por uma tuberculose bilateral escavada, narrou parcela infeliz de sua biografia: estava doente há três anos, época em que sua mãe e sua noiva faleceram, coincidentemente no dia marcado para a realização do seu casamento.

Acometido por 'febre de delírio', Mario foi removido para o Manicômio do Juqueri logo após o duplo enterro, recebendo alta poucos meses depois, quando já apresentava sintomas evidentes da infecção kochiana. Acolhido na enfermaria da casa de saúde do Jaçanã, o paciente novamente foi diagnosticado como 'portador de problemas mentais’, sendo uma vez mais encaminhado ao hospital psiquiátrico e de lá para o sanatório paulistano, onde permaneceu até 1949, ano em que foi transferido para o pavilhão dos tísicos existente no hospício de Franco da Rocha.

No final destas anotações, o tisiologista que preencheu o prontuário referente à segunda internação de Mario Egydio não se conteve, acrescentando no documento: 'historia triste demais', e isto com letras trêmulas, talvez disfarçando lágrimas de solidariedade.

Mas, muito mais do que todas estas expressões, a angustiada ternura médica redobrava seu espaço no momento próximo da morte do infectado. Vários depoimentos denunciam os esforços dos clínicos em iludir o paciente sobre seu estado de saúde quando todos pressentiam o desfecho do caso, até mesmo o próprio tuberculoso. A situação tornava-se mais tensa ainda quando o valetudinário - ou a pessoa por ele responsável pedia alta hospitalar para encontrar o Ceifeiro Implacável no aconchego familiar.

Em dezembro de 1941, a paciente terminal Elizabeth Augusta (P. 2907) rogou, ela própria, liberdade para morrer em sua residência, localizada no bairro proletário do Carandirú, zona norte paulistana. O Dr. Fleury de Oliveira prontificou-se em acompanhar a tuberculosa até a sua residência, permanecendo ao lado da pectária até que ela 
chegasse a óbito, fato que foi registrado na documentação do Sanatório do Jaçanã como tendo ocorrido "no instante em que os sinos das igrejas festejavam o nascimento do Menino Jesus”.

Mas não era só a dor que pautava o cotidiano sanatorial. Os eventos que passo a contar baseiam-se em um prontuário sem número de identificação e em um depoimento de um clínico aposentado, parente de um dos envolvidos no que se relatará, que o acaso me fez conhecer e que me confidenciou fatos sob a condição de o pesquisador preservar o verdadeiro nome dos envolvidos.

Tudo parece ter começado na manhã de 5 de janeiro de 1933, quando deu entrada no Sanatório do Jaçanã uma moça parda, de 24 anos, chamada Eunice. Sua presença imediatamente chamou a atenção de todos - profissionais da saúde, hóspedes e visitantes - pela "beleza de seu corpo e pelo andar felino". A tuberculose que reinava em seu pulmão direito "parece que tinha dado um encanto suplementar" àquela mulher de $1,71 \mathrm{~m}$ de estatura e 54 quilos de peso, conferindo-lhe uma palidez que destacava ainda mais seus olhos cor de mel, fazendo-a parecer, segundo as palavras do médico entrevistado, "uma artista de Hollywood".

O aspecto singular da tísica contrastava com a aparência desoladora dos demais pacientes assolados pela Peste Branca e, antes dela, pela miséria. A esfuziante beleza da recém-chegada despertou o interesse inclusive do Dr. Carlos, um dos principais tisiologistas do hospital e que estava de plantão naquele dia. Contrariando sua indisfarçável aversão de tomar a história clínica dos pacientes novatos, o médico exigiu para si a tarefa de interrogar Eunice, trabalho que todos os seus auxiliares tinham certeza de que não era tarefa, mas sim privilégio.

Na mesma hora, o Dr. Carlos convocou a pectária para interrogatório, não dando tempo nem mesmo para que ela desfizesse a mala que trouxera para a enfermaria. No consultório, Eunice respondeu às perguntas de praxe, abrindo oportunidade para que 0 médico se inteirasse de sua trajetória de vida e de sua enfermidade, que, no essencial, pouco destoavam do que tantos outros pacientes apresentavam.

A mão do Dr. Carlos anotou no prontuário que Eunice era a filha mais velha de um total de oito irmãos, tendo vindo à luz no sertão baiano e sido transferida, ainda menina, para a capital daquele estado. No ano de 1929, logo após o falecimento do pai, a paciente disse adeus aos seus e embarcou em um vapor que partia em direção ao sul, mais precisamente para a cidade paulista de Santos. Nesta localidade, Eunice encontrou colocação de doméstica na casa de uma família abonada e logo depois começou a perceber que alguma coisa estava funcionando errado no seu organismo.

O "forte mal-estar" que Eunice sentia foi se tornando cada vez mais torturante, sendo que estes "incommodos" eram interrompidos quando ela permanecia em repouso por longos períodos. Em 1931, o estado de saúde de Eunice piorou, juntando-se aos padecimentos anteriores "forte dor de cabeça e perda de peso", acompanhados de "tosse, febre, falta de appetite, dôres nas pernas e falta de vontade para trabalhar" e, dois meses depois, "pontadas no hemitorax direito, face posterior, não sendo fortes, nem continuas e sem hora certa para apparecer”. Nestas condições, seu patrão acompanhou-a até o gabinete do clínico geral Manoel Gonçalves, profissional que localizou uma discreta mancha no pulmão direito de Eunice. Diagnosticada a infecção kochiana, 
a tuberculosa foi enviada para o município sanitário de São José dos Campos, onde o bondoso empregador custeou sua permanência em uma pensão e também o tratamento comandado pelo Dr. Nelson D’Avila.

Eunice ficou apenas três meses na estação de cura do Vale do Paraíba. Neste período, apresentou sensível melhora, o que permitiu à pectária receber autorização para voltar a servir na mesa da família santista. Entretanto, pouco tempo depois de regressar ao trabalho, os "antigos incommodos" voltaram a se pronunciar, fazendo com que uma vez mais o patrão de Eunice despendesse recursos, desta vez para financiar as consultas realizadas no consultório particular do Dr. Clemente Ferreira. Como a paciente não apresentasse indícios de recuperação da saúde até fins de 32, o tisiologista concluiu que só havia um encaminhamento para o caso: o isolamento sanatorial, conseguindo ele próprio uma vaga para Eunice no Hospital São Luiz Gonzaga.

O Dr. Carlos ouviu atenciosamente o depoimento da tuberculosa, anotando cada um dos detalhes que lhe era dito e, com esta ação, teceu um texto que provavelmente constitui-se na mais longa e detalhada história clínica registrada na documentação daquele nosocômio. Findo o depoimento, uma vez mais o médico fugiu à sua rotina na casa de saúde, procedendo ele próprio ao exame físico da paciente, também realizado com uma minúcia sem igual.

O fato de a consulta ter se prolongado por "bem mais de 2 horas" despertou a curiosidade dos personagens que compartilhavam do cotidiano sanatorial, alimentando de imediato os falatórios que tentavam descobrir os motivos que levaram ao alongamento de uma entrevista que, de regra, era testemunhada por outros clínicos e fragmentada em várias sessões.

Parece que o médico e a paciente não se importaram muito com o diz-que-diz que passou a agitar a comunidade hospitalar pois, nos dias seguintes, era comum encontrálos constantemente juntos, gozando de instantes de privacidade tanto no consultório - onde o médico redigiu um segundo e ainda mais elaborado prontuário sobre sua paciente especial - quanto nas trilhas que partiam do terreno da casa de saúde em direção à Serra da Cantareira.

Sobre o que conversava o casal nos encontros condenados pela ética médica e também pelos indiscretos olhares dos outros clínicos e dos enfermos? Muitas coisas, inclusive sobre a afeição mútua que pouco a pouco ambos foram assumindo, mesmo que timidamente. O Dr. Carlos - que Eunice já chamava apenas pelo nome, desprovido do título - falava sobre ele próprio, retribuindo as confidências que a enferma havia feito meio forçosamente no transcorrer do interrogatório realizado no dia em que chegara ao hospital. Mais do que isto, o médico compôs neste período um segundo prontuário sobre Eunice, avaliando a enferma não pelo prisma da ciência, mas sim pelo da paixão e da sensualidade; no texto encontrado junto ao prontuário clínico, as palavras empregadas despertaram a curiosidade deste pesquisador: "coraçãozinho amado", "peitinhos em flor”, "minha paciente querida”, "costinhas encantadoras” e várias outras menções provavam o afeto e a intimidade já assumida.

Nos momentos de solidão a dois, Eunice foi se familiarizando com os detalhes da vida do clínico: filho de uma família de médicos, Carlos havia se formado em primeiro lugar na sua turma da Faculdade de Medicina, fato que garantiu o apoio paterno para 
que ele excursionasse pela Europa e permanecesse um ano estagiando no sanatório do Dr. Jacques Stéphani. De regresso ao Brasil, um de seus antigos mestres na escola de medicina o recrutou para colaborar na organização do sanatório da zona norte paulistana, abrindo a oportunidade para que Carlos - que pouco antes havia superado os primeiros 30 anos de existência - fosse em pouco tempo considerado um dos principais tisiologistas do país.

Junto a estas informações, Eunice também ouviu outras coisas: Carlos havia contraído matrimônio com a filha de um rico industrial e fazendeiro, compondo um casal que ganhara fama pelas festas que organizava e que atraía a nata da elite do estado de São Paulo. Por isso, era fato corriqueiro encontrar fotos dele e de sua esposa estampadas nas colunas sociais das revistas paulistas e cariocas, nas quais invariavelmente eram apresentados como um dos pares mais felizes da alta sociedade bandeirante.

Haveria esperança para a concretização do amor entre o médico e a nordestina pobre e infectada? A resposta veio na tarde de uma terça-feira, dia 30 de maio de 1933. No dia anterior, Carlos e Eunice conversaram mais tempo do que o costume, ficando acertado que no dia seguinte ele viria resgatá-la do isolamento. Tudo já havia sido preparado, inclusive a compra de um discreto palacete no Alto de Santana, área afastada poucos quilômetros do distrito do Jaçanã.

Na manhã daquele dia outonal e decisivo, Carlos dirigiu-se para o seu consultório particular, de onde telefonou para seu "primo mais jovem, amicíssimo e confidente" (o depoente mencionado) e contou o que faria nas horas seguintes, obtendo como resposta o "total apoio" do adolescente que estava postado do outro lado da linha.

Encerrado o expediente matutino, Carlos dirigiu-se para sua residência e, logo após o almoço, comunicou à esposa que "não regressaria naquela noite, nem nunca mais". Em seguida, arrancou com o Chevrolet preto que ganhara do sogro na data do seu último aniversário, rumando direto para o Jaçanã. No mesmo instante, Eunice, com o coração aos pulos, estava fechando a mala que guardava seus poucos pertences e os mimos que Carlos lhe havia presenteado naqueles poucos meses de idílio. Uma hora depois, o casal se retirava tão precipitadamente do sanatório que as testemunhas do fato acreditaram que o médico havia simplesmente raptado a formosa paciente!

Vencida a surpresa do momento, a comunidade hospitalar percebeu o que na verdade tinha acontecido, e os próprios funcionários da casa de saúde encarregaram-se de espalhar a notícia que estourou como uma bomba. $\mathrm{O}$ caso só não chegou às páginas das revistas e dos jornais sensacionalistas porque a família da esposa abandonada comprou a peso de ouro o silêncio da imprensa sequiosa por tornar público o 'escândalo'.

A administração da Santa Casa, por sua vez, contribuiu para escamotear o ocorrido, coagindo o Dr. Carlos a se afastar temporariamente do nosocômio, assim como fez registrar no prontuário de Eunice que "a paciente ocupante do leito no 18 da enfermaria feminina recebeu alta por não querer se submetter a exames”.

Certamente o leitor está curioso para saber o que aconteceu com o casal apaixonado. Eis a continuidade desta história de amor: Carlos e Eunice viveram juntos o resto de suas vidas, sempre morando na casa situada em Santana e conhecida como 'castelinho', estranhamente localizada no mesmo quarteirão em que o autor residia quando ‘descobriu’ esta história. O Dr. Carlos voltou a trabalhar no Hospital São Luiz 
Gonzaga, além de assumir cargo docente na Escola Paulista de Medicina, enquanto Eunice recuperou a saúde e assumiu as tarefas de dona de casa, dando a luz a um filho que seguiu a profissão paterna. Carlos morreu no final da década de 60 , seguido poucos anos depois por Eunice.

No território povoado pela solidão, pelo desespero e pela morte, sobrava espaço para a escandalosa quebra dos protocolos éticos cobrados pela profissão médica. E também para o romance.

As instituições que tinham como meta a capacitação médica na área tisiológica mostravam-se, assim, pólos reprodutores da estigmatização coletiva do agrupamento tuberculoso. A condição de uma parcela substancial dos tisiologistas ser ela própria tributária da Peste Branca favorecia a multiplicação dos paradoxos.

Os clínicos e os cirurgiões treinados para entender os tísicos como tipos sociais desregrados nem sempre obedeciam às orientações imperantes nas escolas médicas, irmanando-se aos doentes nos momentos cruciais de angústia e tensão e, por vezes, mantendo prolongados relacionamentos afetivos com seus pacientes. Ocupando posição ambígua no contexto sanatorial, os tisiologistas padeciam da precariedade de recursos ‘científicos’ disponíveis contra a Peste Branca mas, mesmo assim, apresentavam-se como principal opção para aqueles que procuravam a recuperação da saúde e solidariedade. 



\section{8 \\ A Irmandade dos Fracassados}

O trem era o veículo que, de costume, conduzia os tísicos para o ‘exílio’ forçado pela doença. Superado o perímetro dos maiores centros urbanos, os doentes iam percebendo a paulatina alteração da paisagem que, quanto mais se aproximava das áreas de tratamento, mais abria espaço para extensas glebas de mata e terrenos de geografia acidentada. Símbolo maior do desterro prometido, os contrafortes da Mantiqueira representavam o selo da exclusão, ganhando o sentido de majestosos portais de entrada para um universo que resistia em devolver a liberdade para os viajantes tuberculosos.

Desembarcados no destino sanitário, os doentes do peito chocavam-se com o fato de serem acolhidos com todas as reticências alimentadas pelo horror ao contágio. Tanto nas prefeituras sanitárias quanto nas áreas avizinhadas dos sanatórios isolados, eram freqüentes os cartazes que alertavam sobre a proibição da presença dos reféns do Grande Mal em muitas lojas, bares, restaurantes, clubes, hotéis, pensões e até mesmo nas chácaras e moradias. De imediato, os tísicos reconheciam que, mesmo no território do confinamento, vigorava um meticuloso conjunto de prescrições que estabeleciam estreitos limites para a existência infectada.

As disposições preventivistas impunham que os hospitais fossem erguidos em vastos lotes protegidos dos caminhos públicos por extensos bosques de eucaliptos ou por muros de segurança. O silêncio e o isolamento exigidos dos doentes e dos funcionários sanatoriais faziam com que a maior parte dos dramas e dos segredos compartilhados nestas instituições fossem vedados ao conhecimento da sociedade mais ampla.

Os sadios, por sua vez, preferiam tomar ciência de detalhes sobre a vida dos pectários por meio do filtro literário e pelas raras notícias e imagens que propositalmente escapavam do sigilo nosocomial para sensibilizar o tecido coletivo e, com isso, garantir as necessárias esmolas para as entidades caritativas. O Abrigo São Vicente de Paulo, por exemplo, vendia ‘cartões-postais’ cujas ilustrações compunham-se de fotos de seus pequenos hóspedes infectados, esperando angariar algum dinheiro com a exposição pública dessas crianças abatidas pela enfermidade pulmonar.

Sob o véu da filantropia ou do declarado interesse econômico, os sanatórios revelavam-se como o que as Ciências Sociais definiram como 'instituições totais' (Goffman, 1974). Se em geral os nosocômios cumprem as tarefas de cuidar dos corpos enfermos e corrigir o comportamento dos pacientes, as casas de saúde que acolhiam os tísicos deram nova amplitude a esses compromissos. Territórios panópticos de extre- 
mada vigilância, os sanatórios buscavam apresentar-se aos seus pacientes como espaço praticamente fechado ao mundo exterior, tecendo estratégias que objetivavam apropriar-se não só do tempo, mas também dos pensamentos e dos desejos de seus hóspedes, oferecendo elementos que favoreciam a redefinição do 'eu'.

Representando símbolos anacrônicos da peste, os infectados eram definidos como personagens incapazes de aceitar espontaneamente as orientações prestadas pela clínica e, em continuidade, eram tidos como inimigos mortais da sociedade. Reduzidos a valores estatísticos na maior parte da documentação hospitalar, a frieza dos dígitos de identificação desdobrava-se na face colada ao rosto único imposto aos fimatosos: uma legião a ser tratada do corpo e da moral pela medicina, consolada pela religião e pranteada a distância pelos familiares e pelos amigos.

A situação de confinamento imposta aos tísicos albergados fomentava a existência de um mundo apartado e misterioso, legalizando a funcionalidade das casas de saúde. Refletindo a operação segregadora, era comum os médicos dos sanatórios utilizarem uma terminologia espacial para reiterarem o princípio isolacionista, como aconteceu nas anotações feitas pelo tisiologista que examinou o mecânico Humberto Chiadotto (P. 728): "O passiente tendo uma phistula e andando a se tratar della os medicos fizeramno examinar dos pulmões que deu positivo, faz dois mezes mas tambem se queixa da perna direita que doi muito ao levantar e tratava-se lá fora".

A constatação de um mundo 'lá fora' - em contraposição ao ambiente hospitalar - definia os limites dos possíveis contatos sociais mantidos pelos fimatosos, asseverando a solidão que, talvez mais do que a própria patologia, abatia-se sobre os fracos do peito. A variedade de disposições médicas que impediam o livre e ininterrupto acesso da maior parte dos enfermos ao 'mundo exterior' confirmava o sentimento de exílio que aflorava entre os pacientes consuntivos, fazendo com que, também por isso, os pectários temessem o confinamento nosocomial.

\section{Trauma do Internamento}

A ronda da morte e a exclusão do convívio com os sadios incitavam os fimatosos a manterem uma atitude contraditória frente ao momento definitivo de ingresso no labirinto hospitalar. A opção pelo isolamento sanitário, mesmo que admitida pelos infectados como única alternativa possível, anunciava-se como uma experiência dolorosa e povoada de medos.

A tuberculosa Raquel Pereira foi uma das depoentes que narrou em entrevista ao autor o drama íntimo vivenciado no dia em que se iniciou a sua primeira internação hospitalar. Mineira de nascimento, Dona Raquel padecia de um 'resfriado', até que uma violenta hemoptise fez com que a enferma trocasse sua terra natal pela cidade de São Paulo, onde o Dr. Fleury de Oliveira examinou-a no seu consultório particular, diagnosticando a presença de 'discretas cavernas pulmonares'. Em decorrência, o tisiologista recomendou que a paciente recebesse tratamento ambulatorial, descartando a necessidade de confinamento hospitalar. 
Após o choque gerado pelo diagnóstico médico, deu-se a inevitável reunião familiar para decidir o destino a ser dado à consuntiva, ficando acertado que, em desacordo com a orientação prestada pelo Dr. Fleury de Oliveira, a infectada partiria para a estância climática de São José dos Campos, onde o pecúlio do clã permitiria alugar um leito hospitalar. Mesmo que se mostrasse favorável ao encaminhamento dado pelos seus, foi com a voz embargada que Dona Raquel confidenciou os primeiros instantes de seu isolamento:

\begin{abstract}
Meu tio e meu pai vieram aqui em São José e reservaram um quarto para mim no Sanatório Ruy Dória. Internei-me na manhã do dia 17 de abril de 1943, quando tinha 19 anos de idade. Ao chegar no sanatório eu chorava muito e dizia para minha mãe: 'me leva embora pelo amor de Deus, eu quero morrer lá em casa, não quero ficar aqui’. Meus pais ficaram desesperados e então meu pai falou: 'a gente vai almoçar e volta aqui para te buscar’. Aí meus pais saíram, foram embora, não voltaram mais, foram embora...
\end{abstract}

Os sentimentos de rejeição e abandono familiar rememorados pela depoente foram experimentados por quase todos os tísicos. Desprezados pela maior parte de seus parentes - que viviam a angústia da doença em outra dimensão - os tuberculosos lutavam para se posicionar frente a uma realidade impregnada pela negação da liberdade e da singularidade individual.

O abalo emocional causado pelo internamento freqüentemente gerava atitudes de repulsa à condição de confinado. Apesar das dificuldades para obtenção de um leito especializado, os registros do Hospital São Luiz Gonzaga revelam contínuas situações nas quais os fimatosos permaneciam na casa de saúde por apenas alguns dias - horas, até - para logo em seguida exigirem dispensa. Assim aconteceu com o prático de farmácia Romeu Corniari (P. 713) que, internado na data de 10 de dezembro de 1937, saiu do sanatório do Jaçanã no mesmo dia, protestando que "esquecera de resolver negócios urgentes”.

Caso houvesse a recusa clínica de oferecer alta ao paciente desejoso de deixar o nosocômio, o desfecho da situação poderia ganhar o rumo da fuga. O lavrador Theodoro José de Abreu (P. 1615) partiu do município de Pontal, no extremo oeste do estado, para cuidar de sua saúde na capital paulista, esperando uma vaga hospitalar pelo período de quatro meses. Aceito pelo Sanatório do Jaçanã na manhã de 19 de maio de 1943, no mesmo dia o paciente requisitou alta, mas como seu rogo não foi atendido, o lavrador fugiu, não ficando nem mesmo o tempo necessário para que fosse realizada a anamnese.

O terror inspirado pelas intervenções cirúrgicas mutiladoras era outro motivo para a seqüência dos desligamentos que atingiam os pacientes novatos. Como a linha adotada pelo Hospital São Luiz Gonzaga aconselhava o tratamento operatório imediato para os pectários que apresentassem condições físicas relativamente estáveis, muitos recém-chegados eram prontamente encaminhados para a colapsoterapia, fato que os fazia exigir alta, desculpando-se por desistir do internamento. Duas semanas após dar entrada numa das enfermarias do Sanatório do Jaçanã e já com data acertada para se submeter a uma toracoplastia, Maria de Freitas (P. 3048) requereu dispensa do isolamento, alegando motivo surpreendente para a sua saída: “A paciente informa que não 
pode mais ficar nem fazer toraco porque o marido mandou avisar que a quer em casa, pois ele não tem quem prepare a comida que leva para o trabalho".

Em outros momentos, a fuga do isolamento era substituída por comportamentos que beiravam a catatonia. A empregada doméstica Maria da Gloria Moraes (P. 54) e 0 estivador Ulysses Ferreira (F. s.n.) identificaram-se numa história sobretudo dolorosa. Tanto Maria da Gloria quanto Ulyssses eram fimatosos que descobriram-se infectados logo após terem perdido parentes próximos, também contaminados pelo bacilo de Koch. Internados à força por parentes ou vizinhos, em seus prontuários encontram-se anotações semelhantes: "anamnese prejudicada porque o paciente se nega a responder quaisquer questões”.

Os infectados que reagiam ao isolamento com o silêncio levavam os tisiologistas dos sanatórios filantrópicos a convergirem para a conclusão de que os enfermos que assim se comportavam padeciam de "perturbação mental", diagnóstico que foi incluído na documentação hospitalar da empregada doméstica e do portuário. Nesse processo, o prontuário de Maria da Gloria ganhou novas informações, pois em momento posterior à primeira observação, o médico registrou que a tuberculosa "é uma doente nervosa e fica muito tempo num canto sem falar quieta e sem vontade de fazer nada".

O trabalhador portuário desfrutou apenas uma quinzena de tratamento, chegando a óbito no dia 12 de novembro de 1933. A empregada doméstica permaneceu no nosocômio paulistano por mais um ano, sendo expulsa por 'insubordinação'. É bem provável que durante o período de internamento Maria da Gloria tenha redefinido parcialmente sua conduta, pois a regra adotada pelos hospitais filantrópicos era a transferência dos pacientes diagnosticados como doentes mentais para um pavilhão exclusivo para tísicos no Manicômio do Juquerí.

Tal procedimento tendia a não ser reproduzido nas casas de saúde que atendiam enfermos que pagavam pelo tratamento. Acredita-se que o caráter lucrativo destas instituições e a condição social diferenciada dos seus pacientes constituíam-se em fatores que coagiam os tisiologistas a tentarem estratégias amenizadoras do desespero gerado pelo asilamento, negando o rótulo de doente mental para os contaminados que, num primeiro momento, rejeitavam o enquadramento sanitário.

Uma vez mais recorre-se ao depoimento prestado por Raquel Pereira. A extuberculosa narrou um caso que exemplifica os esforços clínicos para lidar com os hóspedes pagantes contrariados com o estado de confinamento:

$\mathrm{O}$ doente às vezes chegava e tinha uma depressão nervosa muito grande. Eu conheci uma moça chamada Lourdes que foi internada, mas não aceitava permanecer no sanatório, sendo desde o início muito agressiva e por isto não pode ficar no meio da gente porque ela estava muito mal da mente. Então, o Dr. Dória tinha uma viúva que trabalhava na rouparia, chamada Dona Júlia. Ela morava dentro do sanatório, tinha um apartamentozinho separado onde vivia com duas filhas tuberculosas. O Dr. Dória chegou e falou para ela: 'Olha, Dona Júlia, a senhora quer tomar conta da Lourdes? É uma moça muito doente, está precisando muita assistência, muito carinho, e eu sei que a senhora tem condições de fazer isso por ela'. Dona Júlia tratou dela com o maior carinho, deu toda a assistência, como se fosse a mãe dela. A Lourdes passou a chamar Dona Júlia de mãe e o Dr. Dória 
começou a tratar e conversar muito com ela. E a doente acabou boa da cabeça, ficou uma moça alegre. Aí ela veio para o nosso convívio.

Em decorrência dos esforços promovidos pela casa de saúde particular, a paciente Lourdes pôde superar o trauma causado pela surpresa do internamento, sem ter de se tornar objeto de classificações psiquiátricas que ampliavam ainda mais o isolamento e a carga de estigmas imposta aos fimatosos.

\section{A Vida Conjunta: a rotina sanatorial}

Ainda nos primeiros instantes da presença no sanatório, o recém-chegado tendia a rejeitar a convivência com outros tísicos. As mensagens que alertavam sobre a periculosidade física e moral dos consuntivos induzia os novos hóspedes a tentarem se manter afastados dos seus 'colegas' de enfermidade, temendo dar nova e mortal dimensão à sua doença, assim como deixar-se contaminar com os pretensos vícios imputados à condição fimatosa.

Vários depoentes informaram que, na primeira vez que receberam internamento hospitalar, inicialmente se apresentaram pouco receptivos à companhia dos demais pectários, evitando fazer perguntas e dar respostas, principalmente quando a tentativa de conversa tomava a infecção kochiana como assunto.

Mais do que isto, os novatos mostravam-se temerosos em utilizar os recursos oferecidos pelos sanatórios, julgando que a recorrência aos itens de emprego coletivo poderia resultar numa ‘superinfecção’ que conduziria rapidamente à morte. Por isso era comum a existência de um medo indisfarçável dos recém-chegados que, mesmo marcados pela pobreza, esforçavam-se para levar ao abrigo hospitalar o maior número possível de utensílios necessários no cotidiano, tais como talheres, pratos, copos, escarradeiras, pentes, roupas de cama e até mesmo agulhas de injeção.

A sensação de abandono e o cotidiano padronizado impunham a presença coletiva, abrindo oportunidades para o processo de acomodação dos temores individuais e favorecendo os elos de sociabilidade entre os reféns da solidão. Mais do que isto, as 'mansões da saúde' - designação institucional fartamente empregada pelos administradores sanatoriais - orientavam a integração entre os enfermos, aplicando sobre seus hóspedes múltiplos dispositivos regulamentadores do cotidiano, todos eles calcados no compromisso de cura e de 'purificação' moral dos fimatosos.

O livro de reportagem elaborado pelo jornalista José Dias Leme (1944) e as informações registradas nos relatórios hospitalares oferecem elementos que, somados, permitem a recomposição da rotina diária das entidades de cura. Pai de uma tuberculosa que usufruiu seus últimos anos de vida no Sanatório Vila Samaritana, localizado em São José dos Campos, o jornalista quebrou a regra que mantinha os sãos afastados das casas de saúde especializadas, conseguindo autorização para permanecer longos períodos no nosocômio, acompanhando a lenta agonia da filha valetudinária, situação que favoreceu o conhecimento minucioso do cotidiano institucional. 
Segundo as observações deste repórter e das notas computadas na documentação nosocomial, sabe-se que os momentos do dia hospitalar eram anunciados pelos toques de uma sineta, devendo ser respeitados por todos os pacientes que reunissem condições físicas suficientes para deixar a cama. Sendo assim, os asilados eram coagidos a abandonar o leito às 7 horas da manhã, dispondo de 30 minutos para se prepararem para o desjejum e para as preces. $O$ período das 8 às 9 horas era reservado para passeios nas áreas vizinhas do hospital, sendo que, esgotado este tempo, todos os doentes deveriam obedecer repouso obrigatório, permanecendo confinados a cadeiras ou camas até às 11 horas, quando se iniciava o almoço. Após a refeição, novo intervalo de descanso acontecia, seguido de lanche às 15 horas e de atividades de lazer e passeio, isto se não houvesse inspeção médica a ser realizada. No final da tarde, ocorria outro momento de repouso, encerrando-se às 19 horas, quando era servida a janta. às 21 horas, logo após as últimas orações do dia, era exigido silêncio absoluto, sendo que, ao soar o último toque da sineta, todos os consuntivos deveriam guardar leito, até a manhã seguinte.

Condicionada a uma marcha lenta e tediosa, a vida dos tuberculosos era normatizada também por disposições nosocomiais que, idealisticamente, deveriam ser obedecidas igualmente por toda a colônia de enfermos, confirmando os estreitos limites de convívio entre os infectados e destes com o mundo exterior. Dentre a infinidade de artigos principiados com a advertência 'é expressamente proibido', os agentes hospitalares arrolavam detalhes padronizadores da existência coletiva, observando que qualquer ato infrator poderia gerar sanções disciplinares que flutuavam entre a admoestação verbal e a expulsão sumária da instituição.

Dentre os atos passíveis de punição, alinhavam-se: escarrar fora do recipiente apropriado, fazer uso de bebidas alcoólicas, dançar sem autorização, jogar a dinheiro, conversar em voz alta ou empregar termos de 'baixo calão', abordar assuntos considerados inconvenientes, perturbar o silêncio nos períodos de descanso comum, apresentar-se de pijama fora dos quartos e das enfermarias, visitar cômodos privativos ao sexo oposto, perambular pelas áreas de serviço do sanatório sem permissão superior, invadir o perímetro residencial dos empregados ou o alojamento dos eventuais visitantes, conservar luzes acesas sem necessidade, depredar as dependências ou os móveis de propriedade da instituição e sobretudo ausentar-se do sanatório sem a anuência clínica ou sem contar com a companhia de um funcionário ou de um colega enfermo designado pela casa de saúde.

A estas cláusulas juntavam-se ainda outras recomendações que davam ritmo próprio a cada uma das atividades desempenhadas pelos tuberculosos. Quanto ao banho, por exemplo, os tísicos tinham direito a uma ou no máximo duas oportunidades por semana, as quais deveriam ser breves e com água morna, sob a alegação de que a higiene íntima prolongada ou excessivamente quente ou fria poderia facilitar a ocorrência de resfriados comprometedores da recuperação da saúde. Os horários de banho, como de resto, eram agendados pelos chefes das enfermarias, acrescentando-se que os pacientes perderiam o direito à ablução, caso faltassem ou se atrasassem para o compromisso marcado. 
Regras gerais divulgadas nos folhetos de propaganda de praticamente todas as mansões da saúde, a condição de pensionista - isto é, de hóspede pagante - parecia abrir oportunidades flexionadoras do ordenamento imposto. Enquanto os sanatórios que assistiam a pobreza deixavam poucas chances de quebra da mesmice cotidiana, os nosocômios que atendiam tísicos abonados permitiam que seus clientes resguardassem um pouco de sua individualidade.

Nestas circunstâncias, os fimatosos de posses tinham a regalia de fazer-se acompanhar de serviçais ou mesmo dos cônjuges, assim como estas instituições ofereciam alojamentos exclusivos, automóveis e motoristas para que seus privilegiados hóspedes pudessem passear pela cidade e fazer compras, fomentando a fantasia de que a Peste Branca havia pouco comprometido os afazeres diários que animavam a vida anterior ao evento infeccioso. Ainda mais, os pensionistas ricos poderiam desfrutar de shows dançantes, cursos de línguas estrangeiras e de pintura, palestras e excursões turísticas organizadas pelos hospitais, que se esforçavam em trazer dos grandes centros urbanos artistas e intelectuais que, de regra, também compartilhavam da condição consuntiva.

Mesmo quando o regimento hospitalar era declaradamente infringido, as sanções institucionais tendiam a ser amenas ou mesmo inexistentes para os pacientes seletos. O enfermeiro tuberculoso José Antonio Duarte, que prestou serviços em vários sanatórios particulares de Campos do Jordão, informou ao autor que os doentes pensionistas eram "perdoados de muitos deslizes”, inclusive de ausências desautorizadas e prolongadas, sendo que, ao retornarem, eram recebidos sem qualquer admoestação clínica.

Em contraposição, para os tísicos pobres sobravam poucas atividades que pudessem amainar a terrível repetição dos dias. A escassez de verbas e o pouco empenho das casas de saúde filantrópicas faziam com que os tuberculosos usufruíssem de raros motivos para julgar agradável a permanência reclusa.

Além da audição conjunta de rádio, das projeções de películas que eram previamente censuradas pela equipe hospitalar e dos jogos de salão, restava a leitura de revistas cujas ilustrações consideradas 'excitantes’ eram recortadas pela vigilância hospitalar e a consulta de livros com teor moralista, de intrigas suaves ou de exaltação nacionalista. ${ }^{1} \mathrm{O}$ pouco mais que favorecia a diversidade das tarefas corriqueiras consistia nas festas de confraternização que ganhavam o sentido de solenidade, acontecendo especialmente nas datas de aniversário dos integrantes da equipe médica ou quando um dos pacientes era premiado com a ambicionada alta clínica resultante da recuperação pulmonar.

A agitação também tomava conta dos sanatórios quando corria a notícia que um doente famoso havia sido internado. Assim aconteceu com Paulo Dantas, que percorreu vários sanatórios de Minas Gerais e Rio de Janeiro antes de chegar ao Sanatorinho jordanense e pouco depois ao Hospital São Luiz Gonzaga, período em que já angariara fama de escritor laureado pela Academia Brasileira de Letras e que compunha um segundo livro sobre a vida dos tuberculosos, sendo por isso insistentemente procurado pelos doentes desejosos de confidenciar algum ‘caso’ ocorrido no hospital. 
No sanatório paulistano, Paulo Dantas (P. 2670) foi registrado como “autor e publicitário”, recebendo atenção diferenciada inclusive do corpo médico, o que resultou na composição de um prontuário bem mais completo do que aqueles produzidos sobre os pectários indigentes.

Situação semelhante ocorreu com o então jornalista Nelson Rodrigues que, internado como pensionista do Sanatorinho jordanense, ao chegar, foi imediatamente reconhecido como repórter d'O Globo, sendo recepcionado festivamente pelos seus companheiros de enfermaria. Para retribuir a acolhida afetuosa, Nelson tratou de compor sua primeira “peça teatral sem nenhuma seriedade” para ser encenada pelos próprios tuberculosos, advertindo jocosamente que o ‘colega' que tivesse hemoptise durante o espetáculo pagaria em dobro o preço da entrada. Tanto para o dramaturgo estreante quanto para seus parceiros de tédio, momentaneamente a vida ganhou um sabor especial: “foi uma farra louca”, lembrou o jornalista (Rodrigues apud Paulo Filho, 1986:429).

\section{Os Pacientes e seus 'Salvadores'}

Os sistemas coercitivos e vigilantes ativados pelas casas de saúde mesclavamse com as promessas de breve cura endereçadas aos infectados que seguissem à risca o ordenamento sanitário. Entre o acomodamento e a revolta, os pectários entendiam o gerenciamento clínico e institucional de suas vidas sob ótica ambígua, orquestrando avaliações próprias sobre os agentes hospitalares.

Os tisiologistas, inevitavelmente, eram os personagens mais visados pela clientela tuberculosa. A cobrança de fidelidade e submissão dos pacientes para com os especialistas do Grande Mal estreitava os laços de dependência mútua, repercutindo no palavreado dos médicos que, para fugirem da responsabilidade individual no processo terapêutico, evitavam flexionar os verbos na primeira e segunda pessoas do singular para dar realce ao 'nós', redobrando o elo compromissado da luta conjunta contra a Peste Branca.

Coube ao tuberculoso Antônio Olavo Pereira (1976:25) lembrar a dimensão imposta à relação entre os doentes do peito e os médicos:

Afinal, o início da vida em comum. Dr. Sampaio lhe dissera uma tarde, usando o plural de confiante intimidade com que tratava os seus pacientes.

- Continuamos progredindo, moço. A partir de hoje, podemos deixar esta cela.

Mas, por enquanto, nada de passeios. A não ser até o quintal. Não é preciso completarmos os três meses.

- E banho, já 'podemos' tomar?

O médico sorrira levemente encabulado, como quem é surpreendido numa atitude sentimental:

- Você está brincando, mas a vida de vocês é a nossa vida. Nas menores coisas.

Nem temos outra, não dá tempo.

Nesta orientação, o facultativo despontava como personagem a ser cultuado, pois seu saber e sua experiência constituíam-se em peças fundamentais no jogo contra 
a morte fimatosa. Em outro sentido, o clínico era apontado como o principal juiz do cotidiano sanitário, cabendo a ele decidir praticamente tudo sobre a vida dos enfermos, desde a viabilidade do internamento hospitalar e a necessidade de intervenção cirúrgica até a permissão de 'licença' - termo emprestado do jargão militar - para o trabalho e a regalia do enfermo casado passar a noite em companhia do cônjuge.

O poder conferido ao médico fazia com que a sujeição cobrada do doente do peito se amalgamasse com um rancor declarado, alimentando comparações e questionamentos sobre as regras impostas pelos doutores. Afinal, se muitos dos tisiologistas e dos seus auxiliares eram doentes dos pulmões, por que eles obrigavam seus pacientes a assumirem uma existência demasiadamente cerceada, na qual quase tudo era formalmente proibido? Se os clínicos tuberculosos trabalhavam intensamente, acumulando prestígio e dinheiro, por que os pacientes deveriam se poupar do trabalho contínuo? Se os médicos e os enfermeiros casavam e desfrutavam do aconchego doméstico, por que a vida familiar era interditada aos isolados? Por que os médicos fimatosos eram apresentados como reservas morais e 'anjos da guarda' da sociedade e 'mártires da ciência', enquanto eles, os pacientes, eram focados pelas lentes sociais distorcidas pela multiplicidade de estigmas?

A multiplicação dos porquês acabava encontrando resposta fácil nos interesses lucrativos que transformavam o funcionamento dos hospitais especializados e o atendimento em consultório em profícuas fontes de enriquecimento.

O escritor Paulo Dantas, ao mesmo tempo que percorria sucessivos sanatórios e se prestava a contar a história da sua vida e da sua enfermidade aos tisiologistas, também compunha páginas de crítica ferina aos facultativos que atendiam os fimatosos, exigindo mais dedicação e eficiência profissional dos médicos, cujo maior pecado talvez fosse confiscar tantos anos de liberdade de sua clientela infectada.

Tentando canalizar as decepções causadas pelo contato com vários especialistas que praticavam em Campos do Jordão, o 'romancista' desabafou:

[Os clínicos] são uns camaradas que não se dedicam às pesquizas. Êles aqui só vêem no individuo dos pés a cabeça um pulmão. E assim mesmo um pulmão como fonte de renda e não como fonte de pesquizas, de estudos cientificos. Veja mesmo o caso do seu médico, o Dr. Aranha, que bem merece o apelido de Dr. Cifrão. O homem de tanto ganhar dinheiro e se meter em negócios já adquiriu até uma semelhança extraordinária com um judeu. Parece um cifrão em pé. Êle é médico, dono de pensão, socio de padaria, alugador de casa, tudo enfim. (Dantas, 1950:107)

Eram freqüentes também as situações em que os pectários buscavam burlar as ordens impostas, encontrando cumplicidade nos iguais na doença, inclusive nos enfermeiros que, recebendo baixíssimos salários, comandavam verdadeiros mercados negros que funcionavam intramuros.

Segundo o depoimento de um antigo funcionário de vários sanatórios paulistas, tudo era motivo de negociação entre os hóspedes das mansões da saúde e alguns enfermeiros: saídas desautorizadas, remédios populares proibidos pela medicina oficial, alimentos, bebidas alcoólicas, tabaco, morfina para aliviar as dores e para o uso dos 
viciados, roupas, companhia sexual, passes para a entrada em prostíbulos e cassinos e até mesmo mandingas para recuperar a saúde.

Outro depoente informou ainda que um consuntivo que fora levado para São José dos Campos por intermédio do amparo caritativo, tornou-se enfermeiro de um nosocômio especializado e, aproveitando-se desta posição, acumulou uma razoável fortuna vendendo secretamente penicilina aos desesperados tísicos, após tê-los convencido que a droga curava a tuberculose. Em troca do 'remédio', o enfermeiro aceitava não só dinheiro como qualquer mercadoria que os doentes pudessem oferecer: aparelhos de rádio, relógios, jóias, ações de companhias, automóveis, enfim, qualquer coisa de valor.

Acredita-se que era grande o número de tísicos penalizados pela quebra dos regimentos, especialmente no contexto dos sanatórios filantrópicos. Entretanto, a documentação analisada evita informar sobre os motivos que levavam a expulsões em série e à aplicação de censuras 'mais leves' aos enfermos albergados, recobrindo de sigilo tais acontecimentos.

As angústias acumuladas pelos hóspedes das mansões da saúde parece que os coagiam a exponenciar os momentos de tensão que pontuavam o cotidiano das instituições de cura, colocando em segundo plano os episódios confirmadores da relativa segurança e do conforto proporcionados pelo viver no recinto hospitalar.

Repetindo com poucas variações o que foi denunciado por outras vozes, uma tuberculosa entrevistada por Oracy Nogueira relatou uma situação punitiva testemunhada num nosocômio paulistano não identificado, mas que provavelmente era o Sanatório do Jaçanã:

No hospital foi adotado o regime de colegio. As pobres doentes devem andar sempre de fila, de braços cruzados. Si alguma doente chega atrazada, no refeitório, capela, etc., é admoestada publicamente e, quasi sempre, ou vá a verdade por inteiro, é sempre com palavras bem pesadas. As cartas são censuradas, tanto as que saem como as que chegam. Pobres doentes! Vivem num constrangimento infernal! Eu vi, e alem de pôr isto aqui no papel, si fôr preciso, e si encontrar ensejo para tal, eu direi a qualquer Diretor do Hospital o que vi, e feriu meu coração profundamente. Vi uma sexagenária, de pé, no refeitório frio, muito frio, em frente a um prato de comida... Tudo isso porque chegou atrazada... Absurdo dos absurdos. Isso é deshumano.(1945:55)

As causas resultantes no desligamento dos enfermos aparecem escamoteadas na documentação relativa ao sanatório da Santa Casa, sendo freqüente a localização de fichas individuais que informam que o paciente recebeu "alta a pedido", enquanto os respectivos prontuários assinalam que o tísico fora punido com alta por "insubordinação" ou “indisciplina”.

A tentativa de decifrar o enigma proposto pelos registros nosocomiais encontrou resposta no depoimento de um tisiologista que atuou no Hospital São Luiz Gonzaga no transcorrer da década de 50. O clínico entrevistado foi um dos poucos personagens que não se recusou a falar ao autor sobre as punições institucionais, esclarecendo que havia uma espécie de “divisão das tarefas punitivas” entre os médicos e as religiosas que serviam como enfermeiras do nosocômio e que pertenciam à Ordem de São José de Chamberry. 
Aos facultativos cabia a decisão sobre a exclusão dos pacientes que se negavam a aceitar as opções terapêuticas, principalmente no que se referia às intervenções cirúrgicas, enquanto as filhas de São José eram responsabilizadas pela vigilância, julgamento e punição dos pectários que infringiam os princípios de sociabilidade assumidos pelo Hospital.

Seguindo esta regra, existem evidências documentais que informam que o comerciário Theodomiro da Silva (P. 714) "foi mandado embora" pelos cirurgiões do Sanatório do Jaçanã porque se negou a aceitar a toracoplastia que lhe fora sugerida, enquanto o pintor espanhol Gabriel Fernandes (F. 23) foi afastado do recinto de cura pelas freiras devido o "abuso de alcool".

Mas, quais 'desregulamentos' outros pontuavam o cotidiano desta casa de saúde para fazer com que um em cada grupo de aproximadamente dez tuberculosos tivesse como destino a expulsão? Segundo o mesmo médico depoente, existiam "dois elementos informais" que levavam ao desligamento dos tuberculosos, sendo eles a negativa do paciente em comparecer aos cultos religiosos programados pelas enfermeiras e também a descoberta de encontros secretos entre infectados de sexos opostos. ${ }^{2}$

Afastados de suas famílias e padecendo com a solidão, era natural que os tísicos tendessem a buscar consolo no ombro amigo dos seus companheiros de isolamento, frutificando em namoros que eram considerados ilegítimos e perigosos pelos agentes hospitalares. O empenho em coibir intimidades maiores, mesmo um simples beijo, encontrava sustentação na idéia de que os pacientes agiam sob comando da exaltação erótica produzida pelo micróbio de Koch, sendo por isso tachados de infratores os tuberculosos que fugiam às proibições. Para estes, aplicava-se uma pena única: o afastamento da instituição de cura.

Clareando o assunto, o escritor e médico Moacyr Scliar assim se reportou à atuação das religiosas na missão de inibir o encontro entre casais de consuntivos:

Quem trabalhou em sanatórios de tuberculosos, como foi o meu caso, conhece a expressão "ouvido de tuberculoso" (...). Também se falava no "tesão do tuberculoso", o que causava grande aflição nas freiras que cuidavam do sanatório, e que, às vezes, passavam a madrugada vigiando as portas que separavam as alas masculinas e femininas. (1992:11)

O peso da imagem do fimatoso como um indivíduo sexualmente pervertido animava os médicos, os religiosos e mesmo os pacientes a unirem esforços para localizar e punir os eventuais transgressores de uma ordem que fundia num só caldo puritanismo moral e chances de recuperação da saúde. É Dona Raquel quem narra um caso em que a delação acionada por uma enferma somou-se ao rigor punitivo do médico e proprietário do Sanatório Ruy Dória:

Havia muita relação sexual escondida no sanatório; as pessoas saíam e iam se relacionar no lugar certo, no hotel ou no mato... Uma vez houve um caso entre um homem casado, vindo de São Paulo, e uma moça bonita e solteira. Ele se apaixonou por ela, foi uma paixão violenta. A moça repartia o quarto com uma outra doente e, numa madrugada, esta companheira acordou e viu o casal junto, na cama. Imediatamente o homem pulou a janela do quarto - que ficava sempre 
aberta - e a enfermeira de plantão não viu nada. Na manhã seguinte, nossa!, foi um escândalo. A colega que viu tudo foi cedinho no consultório do Dr. Dória e contou tudo, exigindo que o doutor fizesse alguma coisa. O Dr. Dória ficou tão brabo que na mesma hora mandou chamar os dois namorados e deu um prazo de 24 horas para eles abandonarem o sanatório, dizendo que enquanto eles não saíssem, ele não cuidaria de mais ninguém que estivesse internado lá. A moça começou a chorar muito e o moço pediu pelo amor de Deus para que o Dr. Dória não fizesse aquilo. Aí o Dr. Dória falou: ‘Não, eu não posso deixar vocês ficarem, eu acho que vocês foram ao extremo. Se vocês quiserem continuar o tratamento comigo, pode, mas só no consultório; morar aqui, nunca mais’. Aí os dois saíram, foram morar numa pensão e continuaram o tratamento com o Dr. Dória. No final, ele morreu e ela sarou e casou com outro.

A seqüência de casos de exclusão contribuía ainda mais para sustentar os antagonismos que impregnavam os ambientes de cura, ditando os limites da convivência entre os doentes do peito e destes com os profissionais da saúde. Em resposta ao ordenamento institucional, os tísicos tendiam a burlar os aparatos de vigilância, identificando os médicos, os enfermeiros e os religiosos que serviam nos sanatórios como responsáveis exclusivos pelas exigências muitas vezes destituídas de valia para o processo terapêutico. Ao mesmo tempo, a ambição pelo restabelecimento da saúde coagia os enfermos à passividade frente ao norteamento clínico, conferindo intensidade às contradições que marcavam a relação entre os pacientes e os funcionários dos nosocômios.

\section{Martírio da Monotonia}

Que sentido tinha o cotidiano para os tuberculosos que precisavam, segundo o palavreado clínico, 'fingirem-se de mortos para recarregar as baterias’ Como os asilados superavam um dia após o outro, chafurdados numa mesmice que acima de tudo significava a não vida, cadência cruel para aqueles que, tudo sugeria, estavam com o tempo de existência próximo do esgotamento?

Os passeios realizados nas horas matinais e no momento em que o sol se punha, os amenos jogos de salão, os namoricos estritamente contidos, as reuniões em torno do aparelho de rádio, todos estes pequenos afazeres diários acabavam esvaziados de sentido pela repetição padronizada no cotidiano. Mais do que isto, o ritmo da vida sanatorial acentuava a paralisação grupal, reiterando o receio de inutilidade compartilhado por muitos homens e mulheres que, até o momento da descoberta dos pulmões contaminados, confundiam suas vidas com o trabalho árduo e contínuo.

Mesmo que as casas de saúde não incentivassem o trabalho dos seus pacientes - pouco se importando com as possibilidades laborterápicas - a busca de atividades produtivas tornou-se prática corrente entre os tísicos. Nos sanatórios que dispunham de poucos recursos, os fimatosos em melhor estado de saúde recebiam autorização para participarem das tarefas de apoio ao funcionamento hospitalar, ocupando no máximo duas horas diárias com serviços que variavam desde o auxílio aos médicos e enfermeiros até as funções de faxina, jardinagem e alimentação dos animais pertencentes ao nosocômio. 
Muitas vezes os próprios infectados encarregavam-se de motivar seus companheiros para a realização conjunta de trabalhos que demandassem pouco dispêndio de energia. No Sanatório Ruy Dória, por exemplo, um depoente informou que os elogios dirigidos a algumas tuberculosas que tricotavam cachecóis e pulôveres para presentear os médicos da casa resultaram na montagem de uma espécie de linha de produção de roupas. Com isso, as vestimentas passaram a ser vendidas à comunidade joseense, não sem antes percorrerem um criterioso processo de esterilização.

A limitação do tempo diário para a realização de tarefas gratificantes fazia com que os prisioneiros das mansões da saúde contassem ainda com muitas horas livres a serem preenchidas de algum modo. Nestes longos períodos de espera da cura ou da morte, pouca coisa podia ser feita, determinando que os doentes do peito se empenhassem em driblar o tédio por intermédio da minuciosa verificação do cenário natural e do ambiente social que os circundavam.

O regulamento institucional que impunha seguidos períodos de silêncio fazia com que os tísicos flutuassem entre as recordações de um passado no qual a doença não existia e a veneração dos eventuais transeuntes sadios. Talvez ninguém melhor que o poeta tísico Rodrigues de Abreu tenha anunciado o voyeurismo que reinava entre os infectados. Confinado às galerias de cura dos distritos sanitários, o escritor compunha versos que se prolongavam na contínua repetição de quem passivamente observa a vida:

A brasa do sol que caíu na montanha accendeu o cachimbo de um deus solitario.

Vêm de lá espaçadas baforadas, nuvens leves que se vão diluindo no ar. (1933:73)

Na seqüência de suas composições, o ‘poetinha’ - como Rodrigues de Abreu era chamado pelos colegas modernistas - enriqueceu o foco de atenções, refletindo a fascinação dos consuntivos pelos corpos belos, pois sadios:

Na manhã de Domingo

pela estrada illuminada

passa uma menina loura. (...)

Fico a olhá-la, feliz, curvando-me da grade.

Como é linda a menina loura!

Ella não tem receio algum dos pobres tísicos,

pois sabe que os pobres tísicos

é que dão vida a esta villa sombria.

Ainda de longe ella volta a cabeça e me espia.

Faz o gesto do adeus esquecido ainda ha pouco...

Linda menina loura!

Moeda doirada de saude,

fulgindo ao meu olhar cubiçoso de doente!

Ao mesmo tempo que verificavam a paisagem e os caminhantes à distância, os exilados tentavam rememorar os momentos da vida que um dia fora saudável, lembrando das pessoas amadas, dos amigos que viraram as costas ao saber da presença 
tuberculosa e também daqueles que surpreenderam pela troca da apatia pela repentina solidariedade ao serem informados sobre o estado contaminado de um conhecido.

Paulo Dantas, Paulo Setubal, Nelson Rodrigues e Antônio Olavo Pereira, dentre outros entisicados, formam o grupo de memorialistas que narraram as doloridas divagações que assaltavam os fracos do peito nas horas de inércia passadas nas cadeiras de lona e nos leitos das enfermarias, forçando os infectados a uma solidão que era difícil de ser quebrada até mesmo pela companhia de outros colegas de desgraça.

A dificuldade de compartilhar os dramas e os medos mais íntimos incitava os doentes a adotarem mascotes como queridos e cômodos confidentes. A presença de cachorros, gatos e passarinhos é um referência constante nos depoimentos dos antigos pectários, sendo que os animais eventualmente podiam ser substituídos por objetos que favorecessem o resgate da 'condição humana’ negada às vítimas da Peste Branca.

No Sanatório Vila Samaritana, por exemplo, a proibição das visitas infantis fez com que uma tuberculosa assumisse um casal de bonecos como filhos, fato que logo cativou todo o pavilhão de mulheres que passou a disputar com a doente Madalena 'mãe legítima' de Rubinho e Juditinha - o direito de mimar as ‘crianças', dando oportunidade para que o jornalista Dias Leme registrasse cenas pungentes como as seguintes:

Andam de cama em cama, os doentes fazem-nas dormir, dão-lhes banhos, ralham com elas e, às vezes surgem brigas e rusgas na 'Dorcas' por causa das reinações das crianças.

Madalena se desvela com seus filhos. Pudera! É mãe! Se uma doente está passando melhor e pode levantar-se, vai logo carregar o Rubinho. Outras doentes protestam contra o desdém que estão votando à Juditinha. Madalena diz que não quer que façam distinção entre os filhos, para êles não crescerem cheios de... vontades.

E quando discutem as doentes? Não tarda a surgir a mãe das bonecas a reclamar silêncio, porque as crianças estão dormindo. (...) E na hora do repouso absoluto, dá gôsto ver aquela mulher gorda, corada, de seios fartos, estendida em seu leito, apertando nos seus braços roliços o Rubinho e a Juditinha, que dão a idéia exata de duas criancinhas dormindo sossegadamente, ao passo que ela as afaga com tanto desvêlo, entoando baixinho uma canção que mais parece um gemido de rôla. (1944:59)

Paralelamente às divagações solitárias, os tuberculosos tentavam se ajudar mutuamente, centrando as conversas na experiência coletiva com o Grande Mal. O contato estendido no tempo incitava o compartilhamento dos destinos, solidarizandose na confissão dos medos e das esperanças aqueles que se sentiam filhos da morte.

A ameaça do esquecimento familiar e do fim solitário coagia os enfermos a falarem sobretudo do que a medicina sanatorial tentava coibir: a doença e suas conseqüências para a existência dos infectados. Nestes encontros, os indivíduos aproximados pela Peste Branca trocavam informações, comparavam as habilidades dos clínicos e a eficiência das estratégias terapêuticas, tornando-se a tal ponto íntimos da nomenclatura tisiológica que, passados tantos anos desde a experiência pessoal com a enfermidade, ainda hoje os sobreviventes empregam os jargões médicos sem cair em enganos. 
Nesses diálogos também se faziam presentes os fatos que agitavam o universo hospitalar. A recordação oral ou escrita de casos que chamaram a atenção dos doentes do peito sugere que tais eventos tenham sido contados e recontados, permitindo que os detalhes das tramas não fossem relegados à penumbra do esquecimento.

As referências à imperfeição moral dos fimatosos são uma constante instrutora das estórias guardadas na lembrança dos pectários, fazendo das debilidades humanas as grandes personagens das narrativas. Neste processo, Nelson Rodrigues fez questão de incluir em suas memórias o fato da morte de um infectado ter sido despudoradamente comemorada pelo irmão do falecido que, também tuberculoso, ambicionava tomar posse das roupas elegantes que o finado havia trazido para o sanatório.

A descrição deste caso delimita as situações aberrantes que ganhavam o interesse dos asilados:

Oswaldo foi enterrar o irmão e voltou correndo do cemitério. Eu o vejo chegar, com as ventas arregaladas. Arremessou-se para as roupas do morto e as possuiu, ali mesmo, à nossa vista. Atracava os paletós, as calças, as camisas, como um sátiro brutal; e dizia: - Foi Deus que mandou meu irmão para cá. Eu estava sem roupa. Andava de calça furada. Virou-se e mostrou os fundilhos. O remendo aparecia, deslavado. (Rodrigues, 1967:150)

Acompanhando esta tendência, a pesquisa realizada pela professora Nelly de Toledo Cesco (1992) colecionou depoimentos de antigos contaminados, sendo que os casos quase sempre deságuam na vala da ingratidão e do egoísmo imputados aos consuntivos. Um dos casos mencionados envolve um capixaba que se transferiu para o Sanatório Vicentina Aranha em conseqüência da tuberculose que corroía seus pulmões.

Na condição de pensionista da mansão da saúde, o enfermo exigiu que sua esposa, mesmo que sadia, permanecesse residindo no hospital e inclusive partilhasse de seu leito, fato que em pouco tempo resultou no contágio íntimo. Quando o marido viu-se livre da infecção, ele abandonou a mulher, partindo para destino ignorado, pouco depois de ter solicitado a transferência da companheira para o pavilhão dos indigentes, local onde a paciente encontrou a morte, sem ter qualquer notícia sobre o paradeiro do marido.

Para além da rememoração dos acontecimentos atribuídos à deformação dos sentidos produzida pela tuberculose, as conversas entre os doentes do peito ganhavam prolongamento quando alguém passava a enumerar as curas milagrosas de pectários que haviam sido diagnosticados como "casos perdidos" pela perícia hipocrática. A fragilidade do arsenal tisiológico e os óbitos seriados fazia com que os consuntivos buscassem amparos e esperanças nos ensinamentos religiosos, sendo que os próprios servidores dos sanatórios incumbiam-se de fomentar o culto e as novenas em louvor aos santos que haviam padecido da moléstia pulmonar.

A condição 'liminar' imposta aos tuberculosos permitiu que alguns deles fossem reconhecidos como santos, tornando-se alvos de veneração pública e especialmente dos infectados. Alguns entrevistados lembraram-se que, nos anos 30 e 40, ganharam intensidade as romarias ao túmulo de José Ezequiel Freire, localizado na cidade vale-paraibana de Caçapava. 
Poeta, jornalista e professor da Faculdade de Direito de São Paulo, Ezequiel Freire abandonou suas múltiplas atividades na capital dos paulistas para tentar a recuperação da saúde na Serra da Mantiqueira, falecendo no ano de 1891. Enterrado à sombra de um salgueiro, a árvore começou a verter água, atraindo as primeiras atenções para o túmulo do poeta. Anos mais tarde, quando a família mandou erguer uma lápide marmórea junto ao túmulo, esta também começou a 'chorar’, resultando na ‘santificação' popular de Ezequiel Freire, consagrado como protetor dos tuberculosos.

Apesar da fama milagrosa alcançada por Ezequiel Freire, ninguém destacou-se mais que o menino Antonio da Rocha Marmo que, apesar de nunca ter sua santidade reconhecida pela Igreja Católica Romana, constituiu-se no principal e mais duradouro alvo nacional das prédicas dos tuberculosos. A ampla aceitação do poder miraculoso do 'santinho' propiciou a continuidade do culto em sua homenagem, sendo que a versão popularizada da vida do 'virtuoso servo de Deus' era assunto de referência obrigatória durante os encontros que aproximavam os hóspedes das casas de saúde.

O que guarda de peculiar a biografia do Santo Antoninho para colocá-lo como vulto cristão adorado pelos infectados? Antonio da Rocha Marmo veio à luz no dia 19 de outubro de 1918, em um sobrado localizado no centro da cidade de São Paulo. A sobrevivência da mãe e do recém-nascido parecia incerta, ainda mais porque o parto aconteceu prematuro e não havia facultativo disponível na Paulicéia que, naquele período, lutava contra uma epidemia gripal que vitimara não menos do que duas terças partes dos habitantes da urbe.

Na confusão produzida pela crise sanitária, um médico bateu por engano na porta da residência da família Marmo, salvando a vida da parturiente e de seu fruto, assim como socorreu alguns vizinhos que tinham sido assaltados pela 'gripe espanhola’. Este foi o primeiro milagre creditado ao menino santificado (Barata, 1938).

A infância de Antoninho foi marcada por acontecimentos surpreendentes. Paralelamente a um conjunto de enfermidades que colocaram em risco a vida da criança franzina, o menino demonstrava profundo apego religioso, tornando-se íntimo de várias ordens religiosas, inclusive daquela que agregava as freiras que atuavam como enfermeiras nos hospitais administrados pela Santa Casa de Misericórdia paulistana.

Aos 5 anos de idade, uma nova provação marcou a trajetória do pequeno: a tuberculose. Por exigência do pai - que ocupava o cargo de chefe da polícia política de São Paulo - Antoninho foi assistido por médicos em sua própria residência, decisão que perdurou até 1925, quando o infectado foi proibido de comparecer às aulas no Grupo Escolar Prudente de Morais. Na seqüência, o tísico foi enviado para continuar o tratamento no município de São Roque e, logo depois, para a cidade de Santos, sendo que o agravamento de seu estado de saúde tornou inevitável o isolamento nas estações de cura de Campos do Jordão e São José dos Campos.

A permanência de Antoninho nas estâncias climatoterápicas contribuiu para a vulgarização das qualidades singulares que seriam exploradas para justificar a santidade do fimatoso. Mesmo padecendo com o contínuo depauperamento do físico, o menino nunca se queixou do desconforto produzido pela consunção, preferindo ocupar seus últimos anos de existência pregando o nome de Deus, visitando os tísicos, amparando os indigentes, diagnosticando casos de tuberculose inaparente, aconselhando 
os desesperados, servindo de advogado aos réus destituídos de defensores, predizendo o futuro, localizando pessoas e objetos perdidos, encenando a celebração de missa e sobretudo adorando a Deus e ao Papa Pio XI, que do Vaticano comandava os rumos da comunidade cristã.

Seguindo o encaminhamento biográfico calcado na trajetória de vários santos e mesmo na de Jesus Cristo, dizia-se que o menino analfabeto fizera-se mestre, corrigindo e ensinando a todos, inclusive aos tisiologistas que aprenderam com o 'prodigioso doentinho' diversas maneiras de identificar precocemente os casos de infecção kochiana. Mesmo que soubesse da brevidade de sua existência e da incapacidade médica em resgatá-lo das garras da morte, o ‘santo heróico’ submetia-se passivamente à orientação clínica, sem nunca se indispor contra a junta de especialistas recrutada para prolongar-lhe a vida.

A morte por caquexia colheu Antonio da Rocha Marmo no dia 22 de dezembro de 1930, momento em que já estava estruturado o culto em louvor do pequeno tuberculoso. Como modelo comportamental, a biografia idealizada para o Santo Antoninho mostrava-se conveniente para aceitação tanto pelos médicos quanto pelos enfraquecidos do peito.

Os profissionais da saúde instigavam a devoção ao menino inclusive porque Antoninho servia de paradigma do 'bom paciente', sabendo perdoar as lacunas médicas e, mais do que isto, seguindo com rigorosa obediência os ensinamentos sanitários que evitavam a disseminação do bacilo de Koch.

Os tísicos, por sua vez, uniam-se na adoração do 'mártir da peste', sobretudo porque a trama de vida do santo aflorava como uma das raras histórias em que o tuberculoso não despontava como fruto pervertido e perversor da sociedade, mas sim como um 'puro', que pela dor ganhou sublime dignidade. Num ambiente no qual o próprio Papa Pio XI insistia em proclamar a enfermidade como forma divina de punição aos pecadores, a constante invocação dos feitos do Santo Antoninho apresentava-se como um dos poucos consolos aos contaminados, sendo que o culto ao 'santinho' ramificou-se tanto nas capelas da cristandade quanto nos centros espíritas.

No ambiente ferido pela solidão, pelos temores e pela fé coletiva, a tuberculose tendia a ser redefinida como uma entidade lúdica, passível até mesmo de abordagens humorísticas. Os doentes que 'viviam escarrando os pulmões a prestações' riam da doença e da morte para exorcizar o sentimento de exclusão e o terror ao fim dolorido.

Nos momentos em que a euforia tomava os recintos de tratamento, a 'bruxa chupada' era empregada como tema inspirador de paródias que faziam as lágrimas cederem vez ao sorriso encabulado. Nestes instantes, os versos lamurientos e desesperados dos fimatosos Auta de Souza e Augusto dos Anjos eram substituídos pela ironia improvisada e cantada em grupo. O estatístico Tulo Hostílio Montenegro (1971), membro de uma família dizimada pela Peste Branca, preservou os seguintes versos de autoria coletiva:

Cidade tuberculosa,

Cheia de micróbios mil,

Cidade tuberculosa,

Sanatório do Brasil. 
A alegria postiça instigava os compositores de ocasião a apurarem ainda mais suas ousadias, dando versão surpreendente à letra de um conhecido tango argentino:

Besame, besame mucho, pero aquí en la frente,

No, no, ne la boca no mes beses no!

Quiero que vivas aunque yo me vaya,

Quiero que vivas, aunque muera yo.

O medo e a dor, quando vividos continuadamente, acabaram sendo requalificados como sinistros e inevitáveis companheiros dos pectários.

\section{A RONDA DA MoRTE}

O cotidiano hospitalar tinha como gerador máximo de tensão as ocasiões de visita do Ceifeiro Implacável. Nestes instantes, tornava-se impossível para os médicos encenarem otimismo, assim como as relações jocosas que buscavam animar o exílio dos infectados ganhavam as cores do mau gosto. O silêncio que imperava nestas horas de desespero dava vez para que o valetudinário revelasse todas as suas dores físicas e morais, por meio de palavras desencontradas e dos gemidos que denunciavam a agonia feroz proporcionada pela respiração deficiente e pelo dilaceramento do tecido pulmonar.

O medo da morte prometida aos fimatosos encontrava como elemento dissimulador os reiterados pedidos feitos aos médicos e aos enfermeiros para que falassem um pouco mais sobre o estado dos pulmões do interpelante. A piedade exigida pela profissão da saúde impunha que as respostas convergissem irremediavelmente para as "boas possibilidades” de cura do paciente, principalmente quando o avalista fosse ele próprio vítima da Peste Branca. Foi com estas palavras que o enfermeiro Duarte tentou iludir uma paciente que, próxima da morte, suplicava algumas sentenças de conforto:

A senhora tenha paciência, a senhora vê, eu também sou doente e estou me recuperando. A senhora vai ficar boa e voltar a viver com sua família. Tenha coragem, muita coragem... Nossa Senhora vai ajudá-la a sarar...

A suspeita de que os profissionais da saúde falseavam as respostas pedidas pelos tísicos incitava os asilados a elaborarem avaliações próprias sobre o estado em que se encontravam suas cavernas pulmonares, buscando indícios comprovadores da marcha infecciosa. A insistente presença de tuberculosos nos recintos onde permaneciam engaiolados os animais que serviam como cobaias revelava-se como estratégia tranqüilizadora dos doentes que queriam saber se não estavam sendo enganados pelos especialistas na doença pulmonar.

A inspeção contínua e apaixonada das cobaias era prática corriqueira entre os enfermos que torciam para que os indicadores vivos não apresentassem sinais da infecção, pois o óbito do animal era o mais flagrante alerta de que a morte rondava os tísicos. A depoente Raquel Pereira retratou vivamente a ansiedade que tomava conta dos pacientes que visitavam os laboratórios, ambiente que formalmente era privativo dos técnicos sanatoriais: 
A gente fazia exames de inoculação na cobaia. Extraíam da gente suco gástrico e inoculavam a substância nos bichinhos. Se a cobaia não morresse dentro de três meses, os médicos matavam a cobaia e a examinavam. Se a cobaia estava boa de saúde, então a gente estava praticamente curada. No começo eu inoculava cobaia e elas morriam em pouco tempo. Era porque o bacilo de Koch estava presente. Eu ficava desesperada...

O sentimento de salvação também encontrava fundamentos na reação do animal utilizado nos testes:

Eu fiz o suco gástrico, inocularam a cobaia e ela foi engordando, ficando bonitinha. A gente já sabia antes do médico que a gente estava melhor. Eu e minhas amigas íamos muito visitar nossas cobaias, isto é, os bichinhos que tinham recebido nosso material. Se a cobaia continuasse normal, comendo direitinho, engordando, era porque a gente estava negativo. Minha última cobaia estava bonitinha. Ela corria na gaiolinha, assim, disposta e gordinha, comia bem tudo o que era dado... Daí eu fiquei convencida que tinha sarado. No fim dos 3 meses mataram a cobaia e ela e eu estávamos negativo...

A constatação do desaparecimento do germe tuberculoso no corpo do paciente não afastava de todo o temor do fim iminente. A consciência de que a Peste Branca era 'doença caprichosa' alimentava o sentimento de insegurança de todos os enfermos. A qualquer instante, o curso da enfermidade poderia reverter marcha, arrebatando inesperadamente a vida.

Se a anorexia progressiva deixava claro que o óbito ocorreria em breve, a hemoptise repentina e mortal poderia ganhar espaço, mesmo naqueles que a tisiologia diagnosticava como próximos da cura. As anotações clínicas e a lembrança dos infectados acumulam registros semelhantes ao que aconteceu com a pectária Laura Peres (F. 343): “Quando se pensava que o caso ia ter desfecho favoravel, teve hemoptyse fulminante, fallecendo em 5 minutos, na manhã de 27 de novembro de 1935”.

Nesse ambiente contaminado pela morte, os sanatórios criavam situações dissimuladoras da agonia dos pacientes terminais, fazendo uso de um conjunto de artifícios que tentavam minimizar a série contínua de óbitos. Principalmente nas casas de saúde que acolhiam os tísicos mais abonados, existiam grupos de servidores especializados em retirar dos quartos os pacientes em estado agônico ou já falecidos, numa discrição tal que muitos enfermos nem se davam conta do ocorrido, fechando silêncio sobre o súbito desaparecimento do hóspede adoentado.

Se a engenharia hospitalar aconselha até hoje que os necrotérios devem ocupar espaço isolado na planta dos nosocômios, a arquitetura sanatorial levava esta orientação ao extremo, posicionando as morgues e os pavilhões para os valetudinários em áreas muito afastadas dos centros de vivência dos infectados. Sob a alegação de que a morte de um dos fimatosos ampliava os medos e agravava o estado da saúde dos demais tuberculosos, os hospitais chegavam até mesmo a proibir a presença dos pectários nas cerimônias fúnebres em memória dos seus colegas, impedindo que se prestasse as últimas homenagens ao falecido. Solitários em vida, mesmo depois do óbito os consuntivos sofriam da dolorosa ausência de companhia. 
Mais uma vez é Dona Raquel quem fala sobre o encaminhamento da morte na mansão da saúde capitaneada pelo Dr. Ruy Dória:

A gente ficava triste quando sabia que uma amiga estava mal, que não tinha mais condições para sobreviver. Então um dia, quando chegava a ponto que tiravam aquela pessoa do convívio da gente, porque o Dr. Dória não queria que a gente visse ela morrer. Então, eles levavam a pessoa para um pavilhão que ficava bem no fundo do terreno do sanatório, onde a gente nunca podia entrar. O pavilhão tinha até um apelido que não era muito agradável: ‘Vai’. Quem ia para lá, ia mesmo. Vai... 'Ah, fulano foi para o Vai’. Então a gente sabia que a pessoa ia morrer. A gente ficava muito triste...

Porém, a escassez de equipamentos e funcionários e a exigüidade das acomodações - características das casas de saúde mais pobres - permitia que freqüentemente o óbito se desse em espaços coletivos dos sanatórios, sendo presenciado por todos os doentes.

A progressão da moléstia pulmonar fazia com que, eventualmente, os grandes vasos sangüíneos fossem dilacerados, abrindo possibilidades para que o enfermo se engasgasse pela continuidade dos vômitos vermelhos. Nestas ocasiões, medo e solidariedade, tristeza e repugnância, angústia e nojo se confundiam, dando forma ao comportamento das desesperadas testemunhas que receavam estar presenciando o que - mais dia, menos dia - a tísica lhes estava reservando.

Um longo trecho assinado por Nelson Rodrigues (1967:192) relata os momentos de agonia e morte de um cantor de tango que, nascido em Jaboticabal, tornou-se famoso nos bordéis do cais santista. Contaminado pela tuberculose, o artista perdeu tudo, da voz à esposa, encontrando a morte no Sanatorinho jordanense:

Uma noite, ouve-se o seu grito: - Sangue, sangue. Alguém acende, rápidamente, a luz. Era a hemoptise. Veio o médico de plantão. Ainda me lembro do ôlho enorme do mêdo. (...) E, súbito, começou a odiar a mulher. Cachorra, cachorra. Xingou-a de todos os nomes. Era terrível de se ver a sua agonia pornográfica. Quiseram levá-lo para o isolamento. Reagiu, babando sangue - Morro aqui, aqui. Queria morrer no meio dos outros, olhando alguém, alguém. E, então, foi deixado em paz. Horas antes de morrer, deixou de odiar a espôsa. Agora o ódio era um desejo triste, tardio, inútil. A enfermaria tôda, numa unanimidade homicida, queria a sua morte. Nenhuma pena e só irritação. E o que assombrava era que ainda tivesse sangue para jorrar no balde.

Eu me lembro de sua última manhã. Só os olhos viviam, só os olhos vazavam luz. Cêrca de umas nove, dez horas, entra a crioula, baiana, $d$. Maria, que tôdas as manhãs varria a enfermaria. O médico e o enfermeiro tinham acabado de sair. Os outros doentes estavam na varanda, tomando sol nas pernas. E, na enfermaria, o moribundo levantava-se do fundo de sua agonia. Via a preta (magra e velha), varrendo, mudando os lençóis e as fronhas. Saltou da cama e veio, cambaleando, atropelar a criada. Esta pula para trás, desprende-se, uma fúria. As canelas finas e espectrais não sustentam mais o moribundo. Quando os outros entram, viram no chão, a ossada aluída. Era, sim, apenas uma ossada com uma pele diáfana por cima. A baiana apanhara a vassoura, a mãos ambas, e ia fender-lhe o crânio. Os outros carregaram o homem de Jaboticabal, enquanto a arrumadeira esganiçava palavrões. E, ali, morreu o cantor agarrado ao seu último desejo. 


\section{Selando o Destino da Irmandade}

O ‘exílio’ conjunto machucava cada um dos tísicos ao mesmo tempo que incitava os infectados a organizarem um espaço de sociabilidade próprio. A tendência ao rompimento dos laços familiares - que muitas vezes não eram cultivados nem mesmo por meio da troca de correspondência - assim como a marca dos múltiplos estigmas favorecia a consolidação de um 'espírito de corpo', determinando que os próprios tuberculosos se definissem como membros de uma ‘irmandade’ cuja condição ultrapassava o estado infectado para se constituir na desoladora imagem do 'fracassado'.

A reiteração destes termos, inclusive nos depoimentos prestados aos clínicos do Hospital São Luiz Gonzaga, fazia com que os pectários cobrassem a existência de um espaço geográfico e social exclusivo para eles próprios. O cerceamento da liberdade dos fimatosos de peregrinar pelas áreas presumivelmente habitadas pelos sadios resultava em constantes conflitos. No bairro paulistano do Jaçanã, um depoente informou que eram corriqueiras as reclamações dos moradores da região que, apesar de terem suas residências distanciadas por quilômetros do sanatório da Santa Casa, mesmo assim protestavam junto à diretoria do nosocômio, exigindo que os enfermos fossem mantidos presos no terreno hospitalar.

Parece que a situação era ainda mais tensa nas prefeituras sanitárias. Neste contexto, os fracos do peito contrapunham-se aos moradores sadios e aos turistas que freqüentavam as estações de cura, estabelecendo os limites de interação entre o 'nós' e os 'outros'. Refletindo estes contrastes, uma consuntiva internada em um hospital localizado na Serra da Mantiqueira assim se referiu à questão quando questionada pelo pesquisador:

Eu sinto isto aqui como uma coisa nossa. Tenho a impressão de que aqui o doente nem tem obrigação de tomar o cuidado que tem lá em baixo. Para mim, a pessôa sã que vem a Campos do Jordão não tem nenhum direito de exigir cuidado da parte dos doentes. Si elas têm medo por que vêm aqui? Isto aqui é nosso. Aqui o doente se sente à vontade, como se estivesse em casa.

Na mesma perspectiva de contraste, outro tísico acrescentou: “Algum dia ainda vamos vêr, por aquí, doente meter faca na barriga de gente sã!” (Nogueira, 1945:32)

A consolidação da identidade grupal colocava em confronto mesmo os tuberculosos que ocupavam diferentes lugares nas malhas sanitárias. Um antigo fimatoso que recebeu tratamento em vários sanatórios localizados nas estâncias climáticas de São Paulo afirmou que somente nas casas de saúde filantrópicas é que verdadeiramente reuniam-se condições para a cura dos pulmões. Isso porque, enquanto as normas eram 'rigidamente seguidas' nos hospitais para indigentes, nos 'sanatórios para ricos' - e neste ponto ele citou o joseense Sanatório Ezra, mantido pela colônia israelita - a vida era tão agitada como se os doentes vivessem em um 'hotel de grã-finos sadios', não oferecendo oportunidade para o necessário repouso dos pacientes.

Seguindo a mesma orientação, outro informante confidenciou que as pensões que acolhiam os tuberculosos eram "verdadeiros clubes de cafajestes”, concluindo 
que os hóspedes destas casas "não levavam a sério qualquer tipo de ordem médica, fingindo-se de sadios para se divertir na cidade".

Dando continuidade à operação classificadora dos vários segmentos que compunham a irmandade, os consuntivos buscavam ainda se distinguir dos demais núcleos de infectados por meio da divulgação de intensos elogios ao tisiologista responsável pelo tratamento dos pacientes de um determinado sanatório. A dependência nutrida pelos doentes em relação aos seus médicos frutificava em louvores que convergiam para a qualificação do facultativo como 'o melhor de todos os especialistas' atuantes na região (senão do país) e que ele estava realizando pesquisas que um dia resultariam na descoberta do agente curativo da tuberculose.

Esse tipo de falatório atingiu inclusive o Dr. Ruy Dória. Logo após a capitulação italiana na Segunda Guerra Mundial, este médico visitou a cidade de Nápoles, onde estagiou em vários hospitais e aprendeu a técnica de aspiração endocavitária, recurso clínico desenvolvido a partir do ano de 1938 pelo médico Victorio Monaldi. Ao regressar a São José dos Campos, o Dr. Dória deu início à prática de drenagem com aspiração das cavernas pulmonares, fato que permitiu que muitos dos seus pacientes atestem até hoje que o tisiologista brasileiro inventou tal intervenção, contribuindo definitivamente para o esforço mundial de cura da Peste Branca.

Apesar das tensões e conflitos que agitavam a irmandade dos fracassados, a idéia de agrupamento diferenciado prevalecia, dando consistência ao universo dos tuberculosos. A perda diária de membros e a incorporação de novos 'irmãos' não impedia a vigência de uma espécie de código ético entre os infectados, favorecendo inclusive a composição de uma infinidade de gírias que tornava o diálogo travado entre os fimatosos quase totalmente fechado para os 'outros', isto é, para os personagens que não estivessem diretamente envolvidos com o cotidiano dos infectados.

A consulta à pesquisa elaborada por Oracy Nogueira (1945) e a conversa com antigos pacientes de sanatórios permitiu o acesso a cerca de uma centena e meia de gírias empregadas pelos pectários. Mais do que um código que permitia o sigilo das conversas mantidas entre os doentes do peito, percebe-se o temor dos tísicos em pronunciarem o nome de tudo o que se referia à condição enfermiça, como se a anulação das referências diretas à doença e aos seus desdobramentos tornasse mais leve a pena imposta pela corrupção pulmonar.

Nas conversas entre os fimatosos ‘micuim' ocupava o lugar de bacilo de Koch, 'arriar a asa' ganhava o sentido de fazer toracoplastia, 'mariquinha' era referência preferida para escarradeira de bolso e ‘curado’ servia como sinônimo de morto.

Parece que os pectários evitavam a todo custo chamar a doença do peito e o estado enfermiço pelas suas designações próprias, substituindo-as por uma pluralidade de expressões. A doença, doença ruim, doença que não se fala o nome, a filha da puta, o mal, insidiosa, lolose, magrinha, meu xodó e brasileirinha eram alguns dos nomes emprestados à tuberculose.

O adjetivo tuberculoso, por sua vez, ganhava ramificações surpreendentes: avenca, baleado, bichado, bicicleta, bombardeado, cabide, cagado, carunchado, cavernoso, chumbado, chuveiro, colega, companheiro, condecorado, comunista, derrotado, doente, dragão, estegomia, fariseu, fibroso, ficho, fracassado, fundo, granfino, guarda- 
chuva, girassol, goiaba, imprestável, inocente, irmão, jacobino, metralhadora, nazista, pêssego, palito de fósforo, patrício, pinhão chocho, pinhão cozido, réco-réco, spitfire, ter somente o chassis, tepê, trinta e três e turista.

As consuntivas consideradas bonitas e volúveis recebiam ainda uma outra designação: Vivien Leigh. E isto porque, segundo um depoente, a atriz norte-americana estava no "auge da infecção quando atuou esplendidamente em ...E o Vento Levou", sucesso cinematográfico no ano de 1939.

Neste contexto, os contornos da irmandade ganhavam dimensão nova, fazendo de todos os sanatórios a nação dos fracassados que trocavam informações e angústias. A rotina da busca da saúde impunha que um mesmo enfermo percorresse seguidos hospitais especializados, até que a morte, a cura ou o desânimo colocasse fim à sofrida peregrinação.

As imagens igualadoras dos consuntivos resultavam na concepção da existência de um território descontínuo no espaço, mas abrangente como rede. Isso permitia que, independentemente das trajetórias sociais e das reações individuais frente à moléstia, os infectados vislumbrassem a participação em um grupo uniforme, composto sob a égide da peste:

Um tuberculoso é um elemento sem pátria, nem fronteiras (...). Um ladrão chinês é um ladrão chinês, diferentíssimo do ladrão turco, brasileiro, norteamericano, a começar pelas coisas que furta, como furta, etc... Um sujeito honesto é também diferente em cada país, como o gigolô, o político, o funcionário público, o vendedor ambulante. Mas um tuberculoso é o mesmo em qualquer parte do mundo, internacionalizado pelo mesmíssimo bacilo. (Alphonsus, 1976:220)

Definia-se assim o dia-a-dia da 'irmandade dos fracassados'. A sujeição ao isolamento sanitário moldava o cotidiano dos pectários, estabelecendo os limites da existência de uma parcela dos tuberculosos. Aglutinados em sanatórios isolados ou nas prefeituras sanitárias, os doentes do peito viviam a 'aventura' da enfermidade, criando dispositivos para preservar um mínimo de individualidade frente às imposições institucionais que visavam à transparência e à fiscalização dos atos de cada um dos hóspedes do confinamento sanitário.

Nestas circunstâncias, ganha maiores evidências o posicionamento negador do doente como 'vencido'. Apesar dos próprios enfermos apresentarem-se como 'fracassados', eles reagiam frente à doença, à perda de privacidade e à estigmatização que persistia inclusive nos ambientes de cura. É certo que tanto os movimentos individuais quanto os coletivos eram pautados por indecisões e ambigüidades, fato que, antes de desqualificar, conferia sentido próprio à trajetória das vidas contaminadas.

\section{NOTAS}

1 O filho de uma enfermeira que trabalhou no Sanatório Adhemar de Barros, em São José dos Campos, guarda algumas obras que pertenceram ao seu pai e, antes deste, à casa de saúde. Dentre as obras preservadas, encontram-se os romances de Madame 
Delly, os ensaios históricos assinados por Varnhagen e por Paulo Setubal, as apologias integralistas de Plínio Salgado, as crônicas das testemunhas das revoluções paulistas de 24 e 32 e também a coleção completa de discursos de e sobre Getúlio Vargas, editadas pelo DIP.

2 A taxa de uma expulsão para cada dez tísicos albergados foi conseguida por meio da análise de 507 prontuários, sendo que, deste total, 53 tuberculosos foram desligados compulsoriamente do Sanatório do Jaçanã. 


\section{9 \\ Vozes da Tuberculose}

“Eu me sentia só. Depois que fui internado, parece que não conseguia mais saber quem era eu próprio. Nem mesmo as brincadeiras dos colegas do sanatório conseguiam me dar um pouco de alegria. Eu era solitário.”

Esta confidência feita por um sobrevivente da tuberculose anuncia que nem mesmo a solidariedade tensa e fraternal que animava a colônia dos infectados oferecia amparo suficiente para atenuar as angústias geradas pela experiência pessoal com a moléstia pulmonar.

Desde que o enfraquecido do peito se vira arrebatado da segurança cotidiana da saúde, sua privacidade fora-lhe pouco a pouco confiscada. Em busca de explicações para o estado infectado, a família, os amigos, os vizinhos, os religiosos e os médicos uniam esforços esmiuçadores da vida do tuberculoso, reduzindo-a a objeto de indagações públicas que tentavam elucidar o processo existencial que transitara da saúde para a enfermidade.

O isolamento sanatorial constituía-se no momento consagrador de um rito de passagem que confirmava a descaracterização individual dos tísicos. A padronização exigida pelas teias hospitalares encontrava desdobramento na ética comportamental cobrada pela irmandade dos fracassados, colocando em questão a identidade pessoal dos fimatosos.

Impregnados pela multiplicidade de códigos fomentados pela segregação institucional, os asilados tendiam a perder os parâmetros de reconhecimento da própria vida. Os sentimentos de abandono e desalento ganhavam dimensões ainda mais flagrantes quando os pacientes mais pobres eram enquadrados na categoria da indigência. A surpresa dolorida de se ver reduzido a tal rótulo levava os contaminados a se insurgirem, procurando ao máximo fugir da degradação social resultante da sinistra combinação entre moléstia e miséria.

Após ter testemunhado a dilapidação da riqueza familiar e de acompanhar as mortes do irmão e do pai, o jornalista Nelson Rodrigues defrontou-se com a tísica, sendo sustentado pelo salário simbólico que lhe era dado pelo seu patrão, Roberto Marinho. A escassez de dinheiro levou o futuro dramaturgo a buscar tratamento gratuito na Serra da Mantiqueira, sendo que a classificação de paciente financiado pela filantropia foi assim recebida pelo memorialista: 
- O Brown diz que você não pode pagar nada. Você não pode pagar? Um escrúpulo doeu em mim; mas tomei coragem e respondi, vermelho, mas firme: — Não posso pagar'. [O tisiologista] Hermínio enfiou as duas mãos nos bolsos do avental: - Você vai ficar na enfermaria de indigentes. Acho que fiquei branco. No Rio, ouvira falar em 'indigente'. Mas a palavra me soara impessoal; havia entre mim e ela uma distância; não me sentira 'o próprio indigente’. Agora a indigência me tocava, e comprometia, e feria. (1967:194)

Neste processo descaracterizador, a vida dos infectados tornava-se mais e mais marcada pela íntima angústia. A sensação de que nada poderia ser feito para corrigir o rumo que a existência tomara coagia os fimatosos a buscarem relacionar o tempo pretérito vivido com o presente infectado, traçando pistas esclarecedoras dos motivos que os haviam confinado no território desolador da peste. Era o momento em que cada um dos infectados se defrontava, solitariamente, com a pergunta: “quem sou eu?”.

‘Quem sou eu?’ Terrível equação a ser resolvida pelos tísicos. Nos depoimentos orais e escritos, essa pergunta aflora como enigma sempre presente, impondo aos consuntivos a busca de respostas avaliadoras de suas tramas de vida e da própria condição de pectário.

A necessidade de comparação entre as condições físicas e morais do tuberculoso e a de outros membros do grupo infectado é uma constante, pontuando as declarações dos antigos fimatosos. Um ancião, que esteve internado no Sanatório do Jaçanã, ao ser entrevistado, negou-se polidamente a falar da experiência vivida há mais de meio século no hospital especializado, limitando-se a uma única observação:

Eu não era igual ao resto dos doentes. Eu era limpo, educado, seguia as regras. Minha doença era leve, nem precisava ficar internado, mas fiquei. A gente que ia para o Jaçanã era terrível. Gente suja, desbocada, que não sabia obedecer... A maior parte daquele pessoal já estava próximo da morte. Eu me curei porque sabia me cuidar, era esperto.

Os estreitos limites hospitalares ofereciam poucas chances esclarecedoras do 'eu', acumulando padecimentos que, se não fossem minimizados, resultariam na morte provocada como desfecho da trama da vida adoentada. A impossibilidade de articular a nova identidade reclamada pelo tratamento estigmatizador e pelo cerceamento institucional favorecia a sucessão de suicídios que feria as mansões da saúde.

Apesar da observação hipocrática que ensinava ser a 'psicologia do tuberculoso' incompatível com a tendência suicida, o número de situações nas quais os albergados colocavam deliberadamente fim à existência ganhou dimensões significativas no período anterior a 1945, chamando a atenção inclusive do Dr. Napoleão Teixeira. Em sua tese de cátedra, este médico declarou que, não obstante o silêncio clínico e a ausência de apoios estatísticos, “são, na verdade, numerosos os suicídios nesta classe de doentes” (1947:105).

O alerta de que “A limpeza Deus ama”, gravado em placa há décadas fixada numa das paredes do Arquivo Central do Hospital São Luiz Gonzaga parece exigir cautela dissimuladora nas anotações médicas referentes aos pectários que se decidiram pelo abreviamento voluntário da vida. Sentença aberta para múltiplas interpretações, 
possivelmente também servia como aviso para os clínicos empenharem poucas palavras no registro das situações que poderiam colocar em dúvida a 'solidariedade cristã' que, formalmente, direcionava o cotidiano institucional. Mesmo assim, na coleção de prontuários consultada, foi possível localizar 11 casos de pacientes suicidas, sendo que na maioria destes registros não houve qualquer tentativa de preservar detalhes sobre as circunstâncias em que ocorreram tais óbitos.

A única exceção encontra-se na documentação referente à paciente Idalina Galvão Guimarães (P. 692), uma “dona de casa” oriunda do município de Avaré. Sentindo-se adoentada há cerca de quatro anos, Idalina primeiramente buscou tratamento com um “dono de farmacia”, recebendo remédios contra "lombriga”. Como seu estado de saúde não melhorasse, a mulher procurou um clínico que exercia em Avaré, sendo então diagnosticada como "doente do figado" e, pouco meses depois, como estando grávida.

Como o farmacêutico e também o médico enganaram-se em suas conclusões, Idalina permaneceu em casa, perdendo peso e vida até que "um amigo motorista de caminhão" compadeceu-se de seu estado, encaminhando a doente até a Santa Casa de São Paulo, onde a paciente soube estar tuberculosa, situação que lhe abriu as portas do Sanatório do Jaçanã. Nos 11 meses de permanência no nosocômio paulistano, a mulher de $1,74 \mathrm{~m}$. de altura teve seu peso reduzido para menos de 40 quilos, sendo durante todo esse tempo acometida por pequenas e grandes hemoptises, fato que não impediu que os tisiologistas declarassem que a pectária "havia melhorado muito desde a sua internação".

Na noite de 16 para 17 de janeiro de 1937, o sono da tísica certamente foi roubado pela tosse, pela dor e pelos soluços próprios e alheios, exigindo que a asilada questionasse a rede de sentidos que a ligara ao universo da infecção. Naquelas horas escuras e assaltadas pelo desespero, a fimatosa defrontou-se com uma multidão de interrogações irrespondíveis, resultando na única certeza de que a tuberculose arrebatara-lhe bem mais do que a saúde.

Na manhã seguinte, Idalina sorrateiramente afastou-se dos olhares vigilantes de suas colegas e dos funcionários da Santa Casa, atirando-se em um poço localizado em parte erma do terreno hospitalar, perecendo por afogamento. Considerada suja de corpo e alma e reduzida a um número de inscrição, a escolha da morte pela água ganhou um sentido purificador. Idalina não precisava mais procurar a identidade da existência consuntiva.

O suicídio, contudo, não era opção disseminada entre os pacientes que, pelo contrário, lutavam pela multiplicação dos dias de vida. As tentativas de compreender a tragédia pessoal incitavam os fimatosos a examinarem suas trajetórias, procurando as possíveis 'causas' para o advento da infecção. Uma pequena parcela de como os doentes do peito explicavam o encontro individual com a Peste Branca acha-se preservada nos registros das anamneses realizadas pela clínica.

\section{A Antropologia da Doença: versóes pessoais}

Dentre tantas histórias confidenciadas na mansão da saúde localizada na zona norte de São Paulo, encontra-se o resumo de vida elaborado por Herminio Francisco da 
Silva (P. 15), um chauffer procedente de Belo Horizonte e filho solteiro de uma família composta por 11 pessoas trabalhadoras. Em um domingo de dezembro de 1931, quando contava 22 anos de idade, o motorista foi convidado pelos seus colegas da vizinhança para "jogar bola" em um "campinho" não muito distante da vila onde a rapaziada morava. Durante a peleja, Herminio sentiu pontadas no hemitórax esquerdo e forte cefaléia, padecimentos estes que não o impediram de continuar no jogo, não se sabendo qual dos times saiu-se vitorioso.

De qualquer maneira, quando a disputa finalizou, ele e seus colegas, "ainda soados" comemoraram o encontro tomando "varios copos de cerveja gelada", certamente discutindo os principais lances da partida que havia terminado. Logo depois da confraternização, Herminio tomou o rumo de casa, sendo surpreendido no meio do caminho por uma "chuva abundante que o deixou completamente molhado".

Já em sua residência, quando se banhava, o atleta de fim de semana sentiu as mesmas dores que o importunaram durante a partida de futebol, tendo, na seqüência, um "vomito de sangue calculado em uma chícara de chá". Socorrido pela mãe com aspirina e um composto de alho e cebola, mesmo assim o jovem mineiro manteve-se em estado enfermiço, fato que o obrigou a procurar assistência médica numa clínica belorizontina, onde um facultativo diagnosticou "uma grippe forte”, prescrevendo xarope e descanso.

O doente fez uso do remédio indicado e não cometeu qualquer imprudência que pudesse comprometer a recuperação de sua saúde. Com isso, as dores no peito e na cabeça cessaram, permitindo que Herminio esquecesse o incidente que marcou aquela tarde de futebol e chuva. Transcorridos dois meses, quando por força de trabalho foi obrigado a dirigir um caminhão até a cidade de Uberaba, o chauffeur tomou nova chuva, logo após a "ingestão de 20 morangos". Poucas horas depois, o motorista mineiro sentiu a mesma indisposição que o importunara tempos passados, acompanhada desta vez de "enfraquecimento, anorexia e muita dispnéa" que, por se mostrarem contínuas, obrigou-o a interromper suas atividades de trabalhador e a novamente buscar atendimento médico, sendo então informado que estava "fraco dos pulmões".

Foi assim que Herminio explicou as origens de sua moléstia para os tisiologistas e para os companheiros de infortúnio que conheceu nos vários sanatórios que percorreu antes de chegar ao Hospital São Luiz Gonzaga. Mas a história do pectário não termina por aí. No decorrer da anamnese, o fimatoso informou que não fumava, não bebia e que não tinha sido atingido pelo contágio venéreo; era motorista desde os 16 anos de idade e trabalhava intensamente, chegando a cumprir jornadas de até 20 horas consecutivas.

Herminio também declarou que inexistia casos de tuberculose em sua família e que sempre gozara de boa saúde até aquele domingo negro, data da primeira hemoptise. Mais ainda, quando interrogado sobre "outras doenças", o paciente lembrou que seus poucos anos de vida haviam sido marcados por uma sucessão de patologias, que iam desde os males próprios da infância até "defluxos", "angina purulenta”, "grippe epidemica de 1918”, "maleita”, “fraqueza” e "bichas”, além de vários acidentes de trabalho.

As confidências feitas por Herminio Francisco da Silva foram narradas em detalhes porque se constituem em uma espécie de paradigma reproduzido, com pequenas variações, em uma infinidade de prontuários elaborados pelos médicos do nosocômio 
paulistano. Os pectários que buscavam assistência especializada apresentavam um perfil bem distanciado das observações apregoadas pelos filhos de Hipócrates como marca dos consuntivos, sendo que os infectados raramente informavam sobre o que os médicos esperavam ouvir: noites de orgias, vícios depravados, taras hereditárias e também exageros físicos e morais causados por outros motivos que não o trabalho estafante.

$\mathrm{O}$ analista cético pode argumentar que nas centenas de prontuários analisados, os pacientes se empenharam em oferecer àqueles que os inquiriam uma auto-imagem purificada, não confessando seus 'pecados' por pudor ou ainda pelo receio de perder a chance de se tratar em um sanatório regido pelos princípios religiosos. Entretanto, acredita-se que, se distorções ocorreram, estas restringiram-se a um número pequeno de casos. A leitura dos depoimentos registrados pela mão clínica alinham os mais diferentes tipos sociais, de padres a presidiários, de professoras a domésticas, sendo improvável que todos esses personagens tenham participado de um mesmo pacto da mentira.

O que era apregoado clinicamente como o modus vivendi típico dos doentes do peito dificilmente encontrava respaldo nos depoimentos sanatoriais. No lugar dos comportamentos desregrados, o que pontuava a existência dos tuberculosos era o trabalho estafante e as precárias condições de vida, sendo a incapacidade para a tarefa produtiva o elemento definidor do estado enfermiço. "Eu trabalhava bem”: era esta a frase empregada pelos doentes para responder à interrogação médica sobre o estado de saúde anterior à moléstia pulmonar, sendo repetida inclusive pelo "artista e garimpeiro" Ciciliano de Araujo (P. 551), pouco antes de falecer, em abril de 1937.

Nesta linha narrativa, compunham-se 'histórias sanitárias individuais' que, definidas pela sucessão de pequenas e grandes enfermidades, eram geralmente desqualificadas pelos médicos e pelos próprios pacientes, porque pouco limitadoras do potencial de trabalho. Percebe-se que a tendência predominante entre os doentes pulmonares era associar o evento fimatoso com os desarranjos que afetavam diretamente o aparelho respiratório, situando-os como raízes primeiras do Grande Mal.

O condicionamento cultural e as poucas décadas que separavam os débeis do peito das descobertas de Pasteur e Koch impunham que raros fossem os personagens leigos que tecessem elos entre a Peste Branca e a ação microbiana. O pressuposto do contágio íntimo era apanágio quase que exclusivo do raciocínio clínico-epidemiológico, sendo exceção casos como o do açougueiro Odilon Orlanch (P. 1737) que, receando a convivência diária com o pai tuberculoso, apresentou-se espontaneamente ao exame radiológico, quando descobriu estar com "mancha discreta no pulmão direito".

A regra fazia buscar em outros quadrantes a causa primeira da tísica. Tanto entre os fimatosos analfabetos quanto entre os intelectualizados, a operação explicadora do estado infectado encontrava suporte em motivos afastados da idéia de contágio. O sacerdote italiano Paulo Rizzi (P. 543), por exemplo, assim relatou os pretensos 'motivos' de sua enfermidade pulmonar:

O doente diz que sua doença começou ha 1 mez, quando tendo respirado em um bonde uma baforada de fumo forte teve um accesso muito forte de tosse secca que durou mais ou menos 3 dias quando começou a ser acompanhado de grippe com escarro branco e logo depois com laivos de sangue. 
O escritor Paulo Dantas (P. 2670) foi outro intelectual que preferiu localizar as origens de sua tísica bilateral distanciada da disseminação do bacilo de Koch no ambiente doméstico. No final de novembro de 1945, o pectário deu entrada na casa de saúde do Jaçanã, sendo objeto de uma longa anamnese em que contara toda a sua vida, informando inclusive que privara durante anos da companhia da mãe e de um irmão, ambos infectados. No mesmo período, o literato estava finalizando uma novela em que a doença que explodia em seu peito foi justificada como sendo conseqüência da "predisposição familiar” (1946:20), nada mais do que isto.

Apesar dessas versões, a lógica garantida pela herança cultural impunha a predominância do postulado que explicava o evento tuberculoso como resultante do contraste entre o calor corpóreo e a temperatura do meio ambiente ou do alimento ingerido. Nesse sentido, muitos enfermos confinados no Hospital São Luiz Gonzaga informaram que a moléstia principiara pouco depois de terem desfrutado de banho em rios e lagos, de serem surpreendidos pela chuva ou pelo sereno da madrugada ou ainda após a ingestão de sorvetes e bebidas geladas.

Em continuidade, segundo os depoimentos que instruíram as anamneses, o choque térmico experimentado pelo corpo resultava em disfunções orgânicas identificadas como “gripe”, “constipação”, “resfriado” e “crupe”, as quais “evoluíam” quando insuficientemente tratadas, ganhando então o curso consuntivo. ${ }^{1}$

Seguindo os termos deste direcionamento, foi assim que o comerciário Orlando Baptista Campos (P. 727) explicou as origens de sua enfermidade, em agosto de 1936: “O passiente julga que os seus males principiaram ha um anno apóz uma forte chuva que o pôz de cama com grippe, febre alta, pouco escarro, mas escarros estes com laivos sanguineos".

Em outros momentos, o 'resfriado' ganhava complementos agravantes que, para os doentes, clareava ainda mais as causas propulsoras da fimatose. Parece que se tornou regra entre os consuntivos que lutaram na guerra paulista de 32 associarem as chuvas, as baixas temperaturas típicas da estação e as agruras materiais impostas pela beligerância como elementos determinadores da moléstia pulmonar. Foi com estas palavras que o motorista negro José Luiz (P. 80) explicou o Grande Mal que o extenuava:

diz que a sua molestia iniciou em Setembro de 1932 durante a Revolução. Por não gostar da comida passou 20 dias a banana e marmelada e apanhou muita chuva na trincheira durante alguns dias, molhando roupa de cama e de uso diario. Logo começou a sentir tosse, febre e fraqueza. Foi para Cachoeira onde foi examinado por um medico q. deu-lhe baixa, nesta epoca tinha 40 de febre.

As mulheres contaminadas, por sua vez, tendiam a somar o 'resfriamento’ do corpo com as condições próprias da fisiologia feminina - principalmente à menstruação e à gravidez - para explicar o fato fimatoso. Por isso, a paciente Vera Mariano (P. 20), de 25 anos, declarou ao médico que sua tísica fora resultado de ter "bebido um chopp gelado quando estava incommodada, tendo na mesma hora uma hemoptise formidavel”.

O acentuado emprego desta linha de raciocínio para explicar o evento patológico tinha, em contraposição, a quase total ausência de observações relacionadas com as condições materiais de vida e de trabalho específicas do proletariado como elementos 
indutores da infecção kochiana. Apesar de inúmeros registros situarem a crise de hemoptise no momento ou logo depois de consideráveis esforços físicos, a persistente tendência desqualificadora do processo de trabalho como fator coadjuvante da tuberculose coloca em igualdade os doentes e seus médicos.

Assim aconteceu com o operário Juvenal da Silva (P. 1728), que "vomitou 1 litro de sangue" numa manhã de maio de 1938, quando "carregava sozinho nas costas uma caixa de louças com cerca de 60 kilos”. No seu depoimento ao tisiologista, Juvenal concluiu que sua enfermidade fora motivada pelos fatos ocorridos na noite anterior à crise hemóptica, quando "jogou ping-pong até altas horas e tomou muito sorvete, percebendo logo ronqueira no peito". Era a explicação que o doente tinha a oferecer ao médico e a si próprio.

Os raros pectários que transpuseram o patamar elucidador oferecido pela tradição, criaram uma sintonia própria entre a Peste Branca e a atividade produtiva, resultando em considerações nas quais garimpeiros, empregadas domésticas, peixeiros e empregados de frigoríficos aproximaram as origens da doença pulmonar com a umidade imperante nos ambientes onde trabalhavam. Um dublê de lutador profissional de box e faxineiro do Cine Coliseu (P. 203) foi um pouco além, informando de que a poeira sempre presente nos locais onde ganhava seu sustento constituía-se no motivo de sua enfermidade, enquanto um repórter santista (P. 2644) acusou o trabalho noturno e os muitos cafés e cigarros que consumia no emprego como os elementos causadores de sua tísica miliar.

Na seqüência, o austríaco Carlos Debeus (P. 1387) talvez tenha sido o paciente que melhor tentou articular a moléstia que o mataria em abril de 1941 com o seu trabalho de licorista. Internado no Sanatório do Jaçanã, foi assim que o pectário esclareceu as origens de sua enfermidade:

Diz estar doente desde o Natal de 1939, quando estava trabalhando na fabrica de bebidas, fabricando uma substancia com cloreto de calcio e acido tartarico, respirou os vapores desprendidos durante 10 minutos sem nada perceber, então começou a sentir falta de ar procurando a rua para conseguir ar fresco. Esta falta de ar durou 5 horas. Desde essa ocasião começou a tossir com expectoração amarelo escura e a sentir muita fraqueza que foi aumentando gradativamente até que o obrigou deixar o trabalho.

Os princípios ‘científicos' e também as perspectivas ‘populares’ vigentes naquela época impediam que tanto os médicos quanto os pacientes oferecessem explicações mais conseqüentes sobre a causação do Grande Mal. Somente muitos anos após o término do isolamento hospitalar é que alguns antigos fimatosos puderam lançar nova luz sobre as causas que os levaram ao enfermamento. Um quarto de século depois de abandonar o Sanatorinho jordanense, Nelson Rodrigues (1967:189) reviu seu passado de tuberculoso, concluindo:

Se me perguntarem por que fiquei doente, diria apenas: - fome. Claro que entendo por fome a soma de tôdas as privações e de tôdas as renúncias. Não tinha roupa ou só tinha um terno; não tinha meias e só um par de sapatos; trabalhava demais e quase não dormia; e, quantas vêzes, almocei uma média e não jantei nada? Tudo isso era a minha fome e tudo isso foi a minha tuberculose. 
Definiam-se assim os limites interpretativos da moléstia segundo os depoimentos dos próprios contaminados. A incapacidade de articular a vida individual com os processos coletivos induzia as averiguações que colocavam a doença como acidente causado por pequenos ‘deslizes’ da vida cotidiana.

\section{A Tuberculose na Primeira Pessoa}

Paralelamente aos depoimentos registrados nos prontuários tisiológicos, outro núcleo documental que oferece explicações individuais sobre a enfermidade pulmonar constitui-se na produção literária. Isso porque, a partir dos meados da década de 30, houve uma sensível alteração na autoria dos textos literários nacionais tematizados pela Peste Branca.

A mão que acalentava a pena que discorria sobre a trama tuberculosa passou ela própria a ser tributária da tísica, competindo com as composições pretensamente 'realistas' que até aquele momento dominavam as incursões pelo tema. Assim, sucessivos autores infectados empenharam-se em seguir o modelo 'intimista' inaugurado por Thomas Mann e Paul Gadenne, narrando em prosa e verso os dilemas do estado enfermiço e, neste encaminhamento, aprofundando as explorações no terreno minado de experiências pessoais com a doença do peito.

Nesse contexto, a reconstituição histórica da vida na primeira pessoa do singular - cirurgia que a psicanálise denomina de 'romance original' (Berry, 1991) - ganha o sentido esclarecedor da identidade postulada pelos contaminados que angustiavam-se pelo fato de se sentirem roubados de si próprios pelas malhas culturais e sanitárias. A necessidade individual de distinguir-se da legião de pares fimatosos animava a confecção de textos que, no final, revelam-se tentativas organizadoras dos fatos da existência que um dia fora saudável.

A urgência do doente do peito descobrir o que 'tinha sido' e o que 'era' fazia aflorar um 'antes' e um 'depois' na trajetória da vida, consagrando a infecção pulmonar como elemento mediador do 'eu' com o universo social. Sob estas circunstâncias, a redação que confunde autor, narrador e personagem cumpria a dupla tarefa de proporcionar aos tísicos uma representação coerente de suas biografias, ao mesmo tempo que alimentava novos pólos de entendimento coletivo dos tuberculosos.

Paulo Setubal, Paulo Sérgio e Jamil Almansur Haddad foram apenas alguns dentre a gama de intelectuais consuntivos que confidenciaram literariamente suas lutas pessoais contra a Peste Branca. A autoridade reclamada por estes escritores supera os limites dos autores que compõem sobre fatos testemunhados na primeira pessoa.

Para além disso, a ameaça sempre presente da morte repentina coagia estes intelectuais a fundirem seus rogos com a voz do Ceifeiro Implacável, advertindo e ensinando os vivos sobre o valor e a desventura da existência regulada pela moléstia e pela solidão. “Eu morri...” Foi com esta afirmação que o poeta Paulo Sérgio (1950:7) filho e sobrinho respectivamente dos também tuberculosos Sérgio Milliet e Ribeiro Couto - inaugurou seu único livro de versos, ironicamente publicado no ano seguinte ao falecimento do autor, ocorrido em julho de 1949. 
Nesta operação que visita o pretérito, pequenos detalhes do cotidiano ganhavam um congraçamento peculiar, garantindo a localização das raízes individuais, marca fundamentadora do 'romance original'. Com isso, os tributários da tísica encontravam na literatura um vasto campo para as indagações sobre a vida infectada, discorrendo minuciosamente sobre os percursos pessoais que, imaginários ou verídicos, confluem para a apologia da dignidade humana que nem mesmo a fatal patologia poderia anular.

Paulo Setubal incorporou no seu diário íntimo a história de sua linhagem, rememorando os personagens, as delícias e os temores que marcaram sua meninice passada em Tatuí, conferindo um tom idílico à sua origem interiorana. O poeta Almansur, por seu turno, coloriu seus poemas com as tintas fúnebres do roxo, do negro e do vermelho, situando suas raízes ora no distante Líbano, ora no ventre da morte. Colocando-se como filho apocalíptico do mundo, até mesmo os ipês da Avenida Paulista, onde o tuberculoso consumiu seus anos de infância, ganharam a marca do extermínio iminente: "Velhinha encarquillhada, teus galhos secos são achas...” (1943:126).

Reconstituído detalhadamente, o tempo já vivido era analisado como o caminho que conduziu do sol irradiante da saúde para as assustadoras trevas da enfermidade. A busca das causas determinadoras da tuberculose encontrava respostas divergentes. Paulo Sérgio acreditava que a peste impunha-se como punição às “ovelhas negras” que diferiam do rebanho humano por rirem desairosamente do Anjo Fúnebre, distanciando-se do Dr. Haddad que, desprezando os conceitos que aprendera na escola médica, voltava-se para os ensinamentos românticos, fazendo do mal consuntivo a sina dos escritores sensíveis.

A idéia de destino aflora nos versos de Almansur como produto inevitável da impotência individual para alterar a rota da vida e escapar dos braços do Grande Mal. A definição da tísica e da inspiração poética como "marcas de nascença” levou o fimatoso a compor versos que retratam o pranto de três mães que sofriam antecipadamente pelas desgraças que um dia abateriam seus adorados rebentos. Enquanto as duas primeiras mulheres segredavam que a dor viria sob a forma da fome e da doença, a última delas ia além, esclarecendo a perspectiva do poeta:

E a terceira com a voz entrecortada

Repleta da maior das tristezas deste mundo,

baixinho segredou: 'Meu filho é poeta...'

E não disse mais nada...

Fez-se o silêncio mais profundo...

E as outras duas soluçaram comovidas... (1943:128)

A ‘confissão pública’ assinada por Paulo Setubal (1949) buscou afastar-se do pendão romântico para, no seu lugar, dar vez a uma versão sintonizada com os posicionamentos da moral e da medicina. O fato de verificar o passado como uma seqüência ininterrupta de "tontices” e seu comportamento como “excessivo em tudo", “assombrado”, “mesquinho”, “carnal”, “chafurdado na torpez” e sobretudo "afastado de Cristo”, permitiu que o intelectual concluísse que sua "vidazinha” não poderia ter outro desfecho a não ser o encontro com a mortal infecção.

No desdobramento das avaliações realizadas pelos pectários, o significado das etapas da vida ganhava um sentido sinistro. O pretérito saudável fizera-se éter, coagin- 
do Paulo Sérgio a identificá-lo ao 'nada', enquanto o futuro se transformava em apenas uma 'abstração'. Suspenso entre o passado e o porvir, os doentes fantasiavam um lugar onde não existisse nem a dor, nem o vômito sangüíneo, nem a solidão, nem a morte, conferindo versões pessoais à Pasárgada bandeiriana.

Enquanto o convertido Paulo Setubal localizava a pátria da redenção como sendo o próprio reino celestial dos católicos, o tísico Almansur buscava a terra prometida na “Cidade Branca” dos cemitérios. Dentre tantas variações elaboradas por este poeta sobre o tema, uma impressiona, pois ritmada pelo trote assustador da tuberculose galopante:

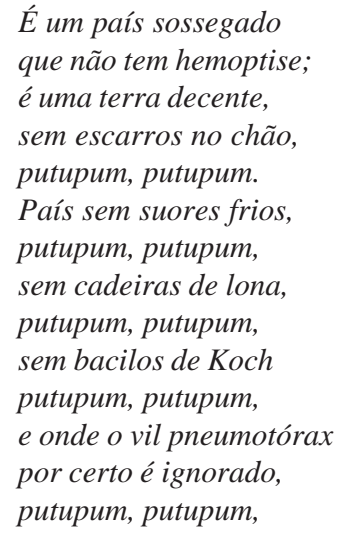

Mas, enquanto o passado se esvaía e a morte não apresentava sua terrível face, o cotidiano do isolado nas prefeituras sanitárias era acima de tudo o cenário do tédio. Em Campos do Jordão e em São José dos Campos, os autores tísicos viviam a vida estancada num limbo que beirava a eternidade, tendo como espelho maior o 'ruço' que cobria a Serra da Mantiqueira e se espalhava pelo Vale do Paraíba. O sentimento de impotência e a solidão imposta fazia com que todos ansiassem pela novidade que nunca chegaria. A existência sem rumo certo roubava a vontade de traçar planos, fazendo com que Paulo Sérgio (1950:21) desabafasse:

Ah se eu tivesse um desejo

nesta tarde de verão...

Um desejo de mulheres

de carinho, de ilusão

de um beijo de compreensão

de amizade ou de dinheiro,

Ah se eu tivesse um desejo...

A repetição diária do mesmo a nada levava, a não ser ao desalento dos 'fracassados'. O desespero nutrido pela mesmice exigia a procura de estimulantes que, no final de contas, a malvada doença teimava em proibir. Ainda é Paulo Sérgio (1950:22) quem fantasiava:

Penso em entrar num bar

fumar ópio, tomar coca

e beber cerveja muita. 
Queimar uma 'herva' bem forte

- Maconha

Liamba-diamba

Cabelo de Negro baseado

a herva do sonho e da morte.

O ‘desejo de alguma coisa’ fazia brotar a urgente necessidade da presença do outro, alguém que pudesse oferecer amor e companhia, repartir o calor do corpo nas madrugadas frias e tornar-se cúmplice de um sofrimento que não tinha mais palavras para expressar intensidade. Nas noites de solidão, o pretenso 'tesão de tuberculoso' ganhava o rumo do devaneio que flertava com a 'vida que não fora'.

Excetuando-se Paulo Setubal - que desfrutou seus últimos anos de vida na companhia da esposa, numa chácara que lhe fora presenteada pela sogra Vicentina Aranha e localizada nas imediações do sanatório joseense da Santa Casa de São Paulo - os autores tísicos convergiam para a ilusão da presença de um sem-número de tipos femininos que ofertavam, sem qualquer receio, o solidário carinho que, de regra, era negado aos doentes do peito.

Do leito situado num hospital da Vila Abernéssia, Almansur (1943:173) lutava contra o vazio de pessoas, versejando longamente sobre a acompanhante ideal:

Peregrino, vens cansado? Acaso te cobre a poeira do caminho longo e longo? Vem ao amor que é fogueira! Vem a féerie do noivado! Que para tu descansares, sou amiga e sou amena como um berço ou como os lares!

Sou amena e sou amiga como a projeção piedosa que há nas sombras dos palmares!

Peregrino, estás cansado? Vem e repousa a meu lado! Para o embalo e para o sonho, a minha garganta agora há de ser a mais canora. Para o embalo e para o sonho vai dizer canções suaves, feitas de sombras e pazes, bem possíveis, bem capazes de servir de embalo às aves!

Peregrino, estás sedento? Para matar tuas sêdes já se faz bem longo o pranto que eu choro enquanto te espero.

Peregrino, estás com frio? Vou cobrir-te com um manto!

Apesar das súplicas, a amizade ansiada tardava em se apresentar. Em vez dela, apenas a mão da freira que acudia os desgraçados que varavam as noites e os dias a tossir, perdendo sangue e vida. A morfina da fantasia era pouco eficiente para amenizar a solidão que feria muito mais do que a dor física. A ordem de repouso torturava.

Os “corpos excessivamente descansados" - eufemismo que o tisiologista Lourival Ribeiro empregou para designar os tuberculosos - revoltavam-se contra as mensagens paralisantes, enquanto a vida fluía 'lá fora’. A tosse irrefreada também era um grito de protesto ao isolamento e à não vida. Logo após eliminar sucessivas golfadas de sangue, freira e médico reiteraram o compromisso de descanso para o fimatoso Paulo Sérgio. A sentença de alerta foi assim ampliada pelo paciente em delírio: "Repouso, repouso, repouso, só repouso... Faça repouso! Cuidado! O Sr. tem toda sua vida pela frente. Cuidado! Hemoptise! Repouso!, Repouso! REPOUSO!”.

Numa última tentativa de proclamar sua angústia, o pectário quis rebelar-se contra a crueldade do destino: "Desesperado ergueu-se com o que lhe restava de fôrças e berrou: — Quero viver, viver o meu sonho!” (1950:37). 
A vida se perdia em 'tristezas sem limites', pois o próprio direito ao devaneio ‘já se fazia cadáver’. A condição de isolamento povoava de metáforas as falas poéticas, buscando dar significado pleno ao desolador sentimento de exclusão. 'Pássaros engaiolados de asas quebradas', os pectários eram insulados nas 'ilhas da esperança'. O pulmão tornava-se o mundo a ser fiscalizado diuturnamente, assim como o mundo transfigurava-se num pulmão misterioso que cultivava as sementes da morte em suas avenidas, em seus becos, em suas escuras choupanas.

Após vislumbrar semelhanças de silhuetas entre as elevações da Mantiqueira e os pulmões humanos, Almansur (1943:104) vasculhou seu próprio órgão respiratório:

Estes pulmões estão cheios de homens,

que, quando é tarde, vão estendendo

o asfalto obscuro na obscura via!

Quanta agonia na nossa vida!

Já se estendeu dentro do peito

a ampla avenida! a ampla avenida!

(...)

No meu pulmão há jardineiros

que, com as suas artes atrozes,

vão cultivando, por minha face,

a grama verde destas cloroses...

E a incursão pelo pulmão-mundo desespera o poeta:

Muita agonia! Muita agonia!

O meu pulmão é podre! podre!

Que pululante bicharia!

Santa Maria! Santa Maria!

Haveria chances para a vida crivada de martírios e mais martírios? A 'bruxa horrenda' tinha como um dos raros lenitivos a promessa religiosa de redenção dos pecados e das dores do mundo. Paulo Setubal foi um dos escritores que entendeu a presença infecciosa não como uma tragédia, mas sim como uma dádiva celestial e redentora da existência individual.

Para Setubal, o sofrimento imposto pela enfermidade o havia aproximado do Deus dos cristãos, fazendo dele um ‘verdadeiro católico' que, para provar a sua subserviência ao Senhor, queimou 300 páginas originais de um livro que, por dissertar sobre 'paixões más e desgrenhadas', não poderia ser assinado por alguém que o Messias havia contagiado com a marca da pureza.

A destruição da obra em 'holocausto a Cristo' foi o momento supremo da conversão religiosa do tuberculoso. Nascia naquele instante um 'novo homem' que diferia em tudo do antigo Paulo, dos ideais aos gostos, das leituras ao 'modo de encarar a vida'. Solidificada a imagem do converso pela tísica, o escritor reinventou o destino dos que privavam com a Peste Branca, anunciando o padecimento infeccioso como fonte segura de felicidade e de elevação espiritual.

O reenquadramento das dores proporcionadas pela moléstia poluidora em fator de purificação levou o memorialista consuntivo a se oferecer como exemplo para seus ‘irmãos de cadeira de lona’. A autocrítica que Paulo Setubal teceu sobre os seus anos 
de saúde, constitui-se em momento singular dos ensinamentos emanados pelo tísico que a enfermidade fez (re)descobrir o angelical sentido da vida:

Tivesse eu um pouco de base, possuísse eu uns princípios católicos mais sérios, andasse eu melhormente embebido da doutrina de Cristo, soubesse ao de leve o que é sofrimento, o que é a dor, como veículo de aprimoramento, então, ao invés de apostrofar, certamente eu abençoaria a mão de Deus na desgraça que me feriu. Então eu não bradaria que aquilo era uma vergasta. Bradaria, isso sim, que aquilo significava uma visita do Senhor. Que aquilo significava um chamado de Deus, chamado direto, claro, paternal, para que eu de novo me acercasse d'êle. Por aquela doença, por aquela fraqueza pulmonar, eu poderia, arredando-me do mundo, mais fàcilmente encontrar-me comigo mesmo. (...) Poderia com firmeza dar um passo, por pequenino que fôsse, no caminho duro, mais belo, do aperfeiçoamento moral. (Setubal, 1949:106-107)

As palavras consoladoras com que o autor de Confiteor tentava amenizar o drama experimentado pelos seus iguais encontrava receptividade relativa entre a irmandade dos tuberculosos. O "nada mais quero ser que a felicidade de não ser" confessado por Paulo Sérgio sugere o caminho sem saída que a fimatose traçara na vida de seus tributários. O Deus de todos os povos certamente era um lenitivo que, para muitos, representava a única companhia na espera da morte ou da recuperação parcial da saúde.

'Quem sou eu?' A questão que teimava em pairar sobre a consciência dos tísicos talvez tenha encontrado melhor resposta por meio dos versos de Haddad (1943:49), numa composição reveladoramente intitulada "Canção do Desesperado":

Amada Clara, na espera, eu sou como cego, eu sou como surdo, eu sou como paralítico, parado numa curva meiga de caminho meigo da Galiléia meiga, esperando Cristo.

Eu sou como o leproso, esperando que o toque, para a transfiguração miraculosa da cura, a mão do Senhor.

\section{A ExPERIÊNCIA EscamoteAda}

A necessidade de estabelecer as dimensões do contato íntimo com a infecção coagiu vários intelectuais tísicos - ou que acreditavam ser a Peste Branca condição futura inevitável de suas vidas - a refletirem publicamente sobre a enfermidade, sem contudo deixar claras evidências de estarem compondo obras que beiravam o ensaio autobiográfico.

O acomodamento na terceira pessoa do singular consistia assim em estratégia protetora contra o conhecimento coletivo da condição pessoal de contaminado ou 'predisposto', inibindo com isso as possibilidades estigmatizadoras. Em decorrência, a literatura e as Ciências Sociais serviram de canais que foram utilizados pelos consuntivos para discorrer sobre o Grande Mal, falando do 'eu' por meio da narrativa centrada nos ‘outros', tributários da Peste Branca. 
Neste contexto dissimulador das averiguações pessoais da trama tuberculosa, ninguém granjeou mais fama que Dinah Silveira de Queiroz. Filha, neta e bisneta de consuntivas que tiveram seus anos de vida abreviados pela enfermidade, a escritora nutria desde a infância forte obsessão pelo óbito fimatoso, acreditando que ela própria tornar-se-ia herdeira do destino contaminado de suas ancestrais.

Porém, a condição supostamente fimatosa que levara Dinah a permanecer por sucessivos períodos nas prefeituras sanitárias paulistas não chegou a público quando o seu romance sobre os doentes asilados em Campos do Jordão apareceu nas livrarias, no primeiro dia de setembro de 1939. A edição inaugural de Floradas na Serra esgotou-se em pouco mais de um mês, despertando as atenções dos críticos que, ao interpelarem a escritora quase estreante sobre os motivos que a entusiasmaram a compor a obra, recebiam em resposta sentenças furtivas e curtas, nada ficando de concreto sobre o assunto.

Desfiando o novelo de suas dúvidas pessoais, Dinah Silveira de Queiroz percorreu seguidos sanatórios, pensões e consultórios médicos localizados na Serra da Mantiqueira para traçar o perfil dos tuberculosos. Como resultado, floresceu a personagem Elza que, no final da adolescência, partiu da capital dos paulistas em direção às montanhas, levando para Campos do Jordão os pulmões avariados e a esperança de cura.

Apesar da opção de colocar Elza como personagem de destaque na trama posta na pensão dirigida por Dona Sofia, a autora deixou-se apaixonar por um tipo secundário que, pouco a pouco foi ganhando corpo na obra, sobrepondo-se em importância aos demais tísicos criados pela escritora. Esta personagem recebeu o nome de Lucilia, "a minha Lucilia - devoradora e complexa” segundo o depoimento que Dinah prestou, pouco depois do lançamento editorial de Floradas na Serra. Mais ainda, a autora confessou que entregou-se vorazmente à composição da vida de sua personagem favorita, sendo que, no final, "para o equilíbrio da narrativa”, viu-se obrigada a destruir "várias páginas, todas escritas sôbre Lucilia” e com isto sacrificou longos trechos do "depoimento sincero de uma infeliz pensionista de Dona Sofia”."

A fascinação declarada de Dinah por Lucilia desdobra-se na composição do romance. Representando o possível alter ego da escritora, esta personagem ganhou autonomia no enredo, reunindo poder inclusive para dar nome a Bruno, um outro vulto que povoa a cidade dos desesperados.

Assemelhada biográfica e fisicamente à sua criadora, Lucilia 'saiu das sombras', elevando-se à condição de voz crítica da colônia dos 'fracassados', alguém que falava o que cautelosamente era silenciado e que, por isso, chocava pela rudez de observar a verdade que desconsolava. Mesmo assim, a incômoda consuntiva transitava entre o universo dos sãos e dos enfermos como um fantasma onipotente que, 'desprezando o seu pequeno público', sempre estava a salvo de qualquer admoestação, tanto de suas colegas quanto de Dona Sofia e do tisiologista responsável pelo seu tratamento.

'Menina impossível', 'doente rebelde', 'criatura detestável', 'sem juízo’ e ‘pequena indecente’ são alguns dos atributos que marcavam Lucilia, segundo outros personagens também reunidos em Campos do Jordão. Isso porque a tuberculosa teimava em remar contra as águas do destino. Apesar da declaração de ser uma "condenada" que não esperava obter cura, Lucilia opunha-se à "força cega e inexorável” que rege o mundo. 
Lucilia se mostrava poderosa, marcando presença nas horas mais tensas da vida do pensionato. Naqueles momentos, seu olhar desafiante fazia com que suas colegas não caíssem em desespero, como no instante em que Belinha agonizava, cabendo então a ela acudir silenciosamente a valetudinária e também amparar as demais testemunhas do óbito que se anunciava.

A dimensão cínica e quase sobre-humana emprestada à Lucilia encontrou limites quando ela conheceu e se apaixonou por um 'homem irreal' que a própria infectada incumbiu-se de batizar com o nome de Bruno. Sem história passada e sem projetos para o futuro, Bruno enquadra-se modelarmente nas companhias imaginárias criadas pelos doentes do peito. O súbito amor da enferma tinha um sentido claro: buscar um aliado contra o destino tuberculoso. Não é por acaso que Bruno foi apresentado como um escritor cuja meta diária era descobrir a potencialidade humana de lutar contra o fatum, termo latino cuja tradução remete ao conceito de destino.

$\mathrm{O}$ desejo de se bater contra a rota que o Grande Mal teimava em impor à existência fez Lucilia compartilhar das apreensões de Bruno. Verdadeira co-autora do romance sobre os doentes do peito, a personagem também se tornou colaboradora do livro de Bruno, acrescentando novas páginas ao texto que estava sendo elaborado pelo amado:

—-Acho que foi Voltaire... É sim, foi Voltaire que disse assim, mais ou menos, não é Bruno? 'Se pudesses modificar o destino da môsca, nada poderia impedir que realizasses o destino de tôdas as outras môscas, de todos os animais, de todos os homens, de tôda a natureza. Sereis, então, mais poderosos que Deus...' É engraçado, Bruno, como foi que guardei isto? (Queiroz, 1939:123)

A luta contra a sina pectária confundia-se com a paixão por Bruno, combinação perigosa que roubava o resto de energia e a beleza de Lucilia. Apesar dos conselhos clínicos para que a tuberculosa interrompesse as noites de vigília amorosa com Bruno, ela se entregou sofregamente ao homem que lhe oferecia companhia e esperanças de fugir ao destino dos contaminados.

Parece que Dinah concluiu que nenhum tísico, nem mesmo sua querida personagem, reunia forças suficientes para alterar o rumo da vida que fora assenhoreada pela Peste. A opção sentimental assumida por Lucilia condenou-a à decadência física e moral. O repentino desaparecimento de Bruno marcou o agravamento do estado de saúde de Lucilia que tornou-se demasiadamente frágil para se manter avessa ao destino e para reagir contra a decisão médica que apontava a toracoplastia como recurso único para arrancá-la das garras da morte.

A operação mutiladora fez surgir uma nova Lucilia, bem diferente daquela que lutava contra a fatalidade da vida. Redefinida em condições de igualdade às suas companheiras de enfermidade, a personagem ofereceu então oportunidade para que Dinah anunciasse os desarranjos dos sentidos que eram proclamados como exclusividade dos doentes do peito.

Se desde o início do romance a autora recobriu os tipos construídos com delicados comportamentos que apenas sugeriam o funcionamento da deformação espiritual atribuída ao bacilo de Koch, o processo de derrota de Lucilia frente ao destino e à 
enfermidade fez com que o roteiro da obra se desviasse para o tenebroso terreno das pretensas anormalidades resumidas na 'psicologia do tuberculoso'.

A ruína de Lucilia significou também a queda de todos os fimatosos. Em conseqüência, a parcela final do livro de Dinah assemelha-se a uma súmula das distorções ‘causadas’ pelo micróbio da Peste Branca: Turquinha revela-se mística exaltada, entregando-se à crença espírita; Elza, já em estágio avançado de recuperação da saúde, rejeita os seus companheiros de infecção e a própria Lucilia mostra-se hipersexualizada, sentindo voluptuosos arrepios até pelo roçar do corpo com as roupas de cama.

Para além destas alterações morais imputadas à toxina bacilar, Dinah Silveira de Queiroz emprestou tensão às últimas páginas de sua obra mediante a exploração da idéia de que os tuberculosos nutriam amarga inveja dos colegas que recebiam alta em razão da cura pulmonar. Seguindo este viés, tanto Lucilia quanto Flávio - personagem apagado e namorado de Elza - mostraram-se declaradamente rancorosos ao saberem que Elza estava livre da infecção e do isolamento nas montanhas. Sentindo-se distanciado da ex-infectada, Flávio anunciou seu descontentamento com a recuperação da saúde da amada, queixando-se: “- Agora... vejo as coisas friamente. Você curada, pronta a retomar o fio interrompido das suas relações, das suas amizades e eu aquí... prêso para sempre” (Queiroz, 1939:252).

O escritor Paulo Dantas, por sua vez, não fazia segredo do seu estado consuntivo, apesar de se proteger atrás da composição literária na terceira pessoa do singular. Ganhador de um prêmio ofertado pela Academia Brasileira de Letras pelo seu livro de estréia, no qual retratou a vida dos presidiários, o autor continuou na senda dos excluídos, escrevendo um conto e uma novela onde explorou o cotidiano dos infectados reunidos em Campos do Jordão.

A novela As Águas Não Dormem... contou com o patrocínio editorial de Monteiro Lobato, que reunia a autoridade de crítico literário com a dor do pai que havia tido, por duas vezes, filhos roubados pela Peste Branca. Apresentado pelo seu padrinho intelectual como escritor da "mais corajosa sinceridade", Paulo Dantas fincou a coluna mestra de seus livros referentes aos enfraquecidos do peito no pântano afirmador de que a toxina do micróbio de Koch somava-se à febre para perverter o comportamento dos pectários, resultando na licenciosidade sexual dos contaminados.

Em decorrência, desde as páginas de abertura do seu primeiro texto sobre os fimatosos, o autor expôs claramente sua proposta purificadora dos seus companheiros de sofrimento:

Sinto-me na obrigação moral de dar uma explicação, afim de evitar possíveis malentendidos na compreensão do problema sexual do tísico. Sou da opinião que se deve criar uma educação sexual especial para os doentes do pulmão. (...) Nêste ponto tenho a consciência tranquila, porque antes de tudo procurei ser honesto comigo mesmo e para com a linha erótica comum da doença. (Dantas, 1946:9-10)³

Estava dado o mote definidor do posicionamento de Paulo Dantas sobre a 'psicologia' dos infectados. Pela vez primeira no contexto nacional, um escritor tuberculoso discorreu exaustivamente sobre as pretensas perversidades morais dos filhos da 'brasileirinha', aceitando na íntegra a versão corruptora dos sentidos apregoada como marca dos pectários. 
O personagem central da novela lançada em 1946 é Ciro que, ao contar sua história de vida, identificou-se plenamente com a biografia do seu criador, fazendo da obra uma espécie de documento detalhador do prontuário do Hospital do Jaçanã iniciado com o nome do paciente Paulo Dantas. "O que tem que ser, será”: o destino foi novamente invocado para selar a inevitabilidade da infecção pulmonar, fazendo do personagem/autor um membro degradado da burguesia, que freqüentava não os 'sanatórios de luxo’ ou as pensões particulares de Campos do Jordão, mas sim as úmidas e sujas enfermarias localizadas nos subterrâneos dos hospitais filantrópicos que funcionavam no sul mineiro e na parcela paulista da Serra da Mantiqueira.

Neste curso, Paulo Dantas retratou a face oculta e miserável da cidade dos infectados. Autoproclamando-se “gato castrado em porão escuro”, Paulo/Ciro vasculhou as fantasias e os desejos que acreditava serem frutos do micróbio, revelando o lado sombrio que nenhum outro literato doente ousou desenhar com tanto requinte. Os personagens focados no ambiente de cura eram feridos por toda sorte de 'aberrações': uns são exageradamente egocêntricos, outros perversos, outros ainda místicos, todos sexualmente pervertidos, computando entre tais desarranjos a comparação do esperma com o catarro expulso dos pulmões e a utilização da palavra 'foda' como brado da indignação coletiva que pairava sobre os doentes do peito.

As tentativas de seduzir o sexo oposto, senão o idêntico, tinham como complemento as fantasias sobre o pretérito repleto de carícias femininas. Na ausência de companhia real ou fictícia, Ciro seguia a conduta dos seus parceiros de enfermaria, entregando-se à prática onanista. Mas, nem mesmo nos momentos de gozo solitário a doença e a moral se esvaneciam, ampliando os medos e os receios dos tuberculosos carentes de tudo.

Após excitar-se com o resto da água que sobrou do banho de uma paciente da mansão da saúde, o fimatoso masturbou-se, sendo imediatamente atormentado pelos fantasmas apregoados com invulgar insistência pelos clínicos e pelos religiosos que serviam no hospital:

O que abatia não era a viscosidade do sabão, era o nojo, o medo da hemoptise, o pêso na consciência e a vergonha de mim mesmo. A água ficou manchada e de corpo limpo destampei a torneira e ví a correnteza levar tôdas as impurezas do mundo, com restos do corpo de Margarida. Depois subí para o quarto, de olheiras, abatido e envergonhado comigo mesmo. Deitei-me e fiquei a manhã inteira a esperar pela hemoptise que não veio. (Dantas, 1946:106)

A sensação de ser um estrangeiro na nação dos consuntivos pobres fazia de Ciro um incansável crítico do ambiente de cura. A ostensiva repressão institucional das necessidades produzidas pelo ‘ardor da febre’ exigiu que o memorialista disfarçado lançasse sucessivas farpas contra os empregados dos sanatórios que, ao cobrar castidade e devoção religiosa dos infectados, tornavam-se arquitetos de um cotidiano sufocante e intimidador.

Na continuidade da trama, Ciro deteve-se na denúncia dos descalabros perpetrados pelos agentes nosocomiais. O tratamento diferenciador dispensado aos hóspedes pensionistas trazia para dentro das casas de saúde as desigualdades sociais que 
colocavam em confronto os pobres e os ricos. Comida, assistência médica, velório, condescendência, respeito e tudo o mais estava alocado em benefício dos endinheirados e, por óbvio, em detrimento dos indigentes. Por isso, Ciro declarou-se chocado pelo fato de seus companheiros de miséria e infecção nada fazerem contra as injustiças que proliferavam na teia higienista. Para explicar tal postura, novamente Paulo Dantas (1946:67) serviu-se dos estigmas ajustados aos doentes do peito, esclarecendo:

Já deduzi que na psicologia coletiva do tuberculoso pobre, uma das formas mais encontradas, é a do conformismo geral. O que o doente mais deseja no mundo é uma cama num hospital, onde êle possa comer, dormir e às vezes ter a ilusão de que está sendo tratado. Da adaptação dêsse desejo essencial é que nasce o seu conformismo fácil e sem revolta.

N'A Cidade Enferma, texto escrito entre os anos de 1947 e 1948, o escritor desenvolveu ainda mais as perspectivas discriminadoras dos 'fracassados'. A reação negativa da população jordanense à sua primeira novela teve como resposta a ratificação dos predicados atribuídos aos tísicos, estendendo-os também para a urbe climatoterápica. Nesta obra, a condição exageradamente erotizada dos tísicos foi reafirmada por meio do diálogo entre os personagens Vítor e Leo Além, ambos aproximados biograficamente ao autor:

- Vítor, você que é um escritor e um estudioso da natureza humana, não acha mesmo que a doença vem afetar a vida sexual da gente?

- Querer negar isto é besteira, é estupidez. As provas estão aí nos tipos que a gente conhece aquí em Campos do Jordão. Pode ser que a razão dessa exacerbação erógena ainda não tenha sido suficientemente explicada pela medicina. Mas que importa a medicina se temos a vida, os exemplos de cada dia a nos bater a porta. (Dantas, 1950:106)

Depois de alinhar os elementos tidos como definidores da hipersensualidade tuberculosa, o literato recorreu a antigos pressupostos para situar os 'pervertidos' doentes e toda a população de Campos do Jordão em uma mesma malha estigmatizadora: "E, mais decisiva ainda é a influência exercida pelo clima. Está provado que uma montanha como a nossa torna a mulher mais mulher e o homem mais homem”.

A operação que impunha a identidade tuberculosa como resultado monstruoso da corrupção moral programada pela Peste Branca feriu também o cunhense Oracy Nogueira que, pectário, viveu em isolamento no Sanatório Ruy Dória no decorrer dos anos de 1936 e 1937. Recuperado da infecção, o doente transferiu-se para a cidade de São Paulo, onde obteve grau de bacharel em Ciências Sociais pela antiga Escola Livre de Sociologia e Política, sendo que, a partir de então, o estudante comprometeu-se em clarear as angústias acumuladas pela experiência pessoal e grupal com a marginalização social engendrada pela fimatose.

Sob o estímulo e a orientação do norte-americano Donald Pierson e do alemão Emílio Willems, Oracy Nogueira confundiu suas atividades de pesquisador com a do homem que buscava entender as reações coletivas frente aos agrupamentos diferenciados, sem, contudo, declarar-se ele próprio vítima do fenômeno que analisava. 
Em setembro de 1945, o sociólogo apresentou para julgamento acadêmico a primeira tese assinada por um cientista social sobre a irmandade dos fracassados, a qual teve continuidade teórica nos anos seguintes, com o estudo dos preconceitos articulados em torno das comunidades afro-brasileiras. Somente em período recente foi que Oracy Nogueira - hoje docente aposentado da Universidade de São Paulo - explicou publicamente os motivos pessoais que o levaram ao estudo dos contatos sociais entre brancos e negros, deixando patente o significado da tuberculose em sua opção profissional:

Os dois anos de isolamento por motivo de doença a que fui forçado e a impressão do estigma que me ficou como seqüela contribuíram para aumentar minha empatia em relação às pessoas de cor que, embora por outra razão, eu percebia estarem também sujeitas a isolamento e estigmatização. (1985:63)

O convívio íntimo com o Grande Mal ganhou expressão maior na produção nogueiriana por meio de sua dissertação de mestrado, na qual o pesquisador apoiouse em questionários, histórias de vida e entrevistas informais para traçar um quadro identificador das atitudes dos doentes e dos profissionais de saúde aproximados pela Peste Branca.

Seguindo as propostas dirigidas pelas ciências sociais norte-americanas - especialmente representadas por Ralph Linton e Ruth Benedict - o estudioso brasileiro tratou parcimoniosamente seu objeto de indagações, declarando "achar tudo natural”, evitando, assim, qualquer sentença avaliadora da vida dos pectários, da rotina imposta pelas instituições de cura e da tisiofobia imperante na época.

O receio de cair em confronto com as perspectivas clínicas e sociais vigentes no período impuseram que o autor se abstivesse de colocar em dúvida a propalada determinação fisio-patológica do comportamento tuberculoso, repetindo em várias passagens do texto que seu intento não era o debate, mas apenas a elaboração de um "estudo exploratório" e destinado a fornecer "hipóteses mais definidas” para serem empregadas em análises posteriores.

Seguindo esta orientação, Oracy Nogueira interpretou a medicina como saber e prática imunes das influências sociais, apontando os leigos - e dentre estes especialmente os agrupamentos 'incultos’ - como responsáveis pelo movimento estigmatizador movido contra os fracos do peito. Na seqüiência, o estudioso acrescentou que:

Parece significativo que, justamente no século XIX, com o apoio das concepções naturalistas do universo, que favoreceram a separação entre as concepções de saúde e enfermidade, de um lado, e da moralidade e religião de outro, tenha coincidido o período ascendente da tendência à romantização da tuberculose e do tuberculoso. (Nogueira, 1945:16)

Mesmo assim, a lembrança da tragédia pessoal pairava sobre o pesquisador universitário, instigando-o a procurar explicações sobre a existência consuntiva que extrapolassem os rígidos limites do biologismo hipocrático. Na busca de novas perspectivas analíticas, o sociólogo deparou-se com os textos produzidos pelo tisiologista João Baptista de Souza Soares, voz isolada na medicina nacional porque se opunha à exclusividade do bacilo de Koch na determinação ‘psicológica' dos infectados, apon- 
tando a importância do isolamento social como fator coadjuvante no processo 'deformador' da personalidade do consuntivo.

O entendimento da medicina como fenômeno apartado das dinâmicas sociais somou-se à hipótese defendida pelo Dr. Souza Soares, condenando o discípulo de Donald Pierson a flutuar entre os quadrantes que anunciavam o comportamento dos 'fracassados' ora como produto da bioquímica do organismo contaminado, ora como resultado psicossociológico do confinamento higienista.

No final das contas, o professor Nogueira optou pela via conciliatória que, ao amalgamar as perspectivas, conferiu vitalidade nova às apregoações que definiam como traço característico das atitudes dos pectários as tendências de intocabilidade, autoafirmação, dramatização da vida, egocentrismo, misticismo e agressividade.

Se a concepção que ressaltava o 'erotismo tuberculoso' foi cuidadosamente evitada na dissertação sociológica, o mesmo não aconteceu com outros atributos anexados à existência consuntiva. O registro do 'comportamento agressivo' como marca dos fimatosos, por exemplo, ganhou a atenção do pesquisador que, ao procurar concluir sobre a questão, deixou claras as dificuldades e as reticências das Ciências Humanas na tarefa de análise do tema:

Ao nosso vêr, a chamada 'agressividade' dos doentes de Campos do Jordão, por exemplo, não é apenas um reflexo do conflito de interesses entre êles, de um lado, e os médicos, administradores, enfermeiros e demais profissionais de outro; nem é tão pouco, efeito apenas da ação fisiológica das toxinas do bacilo de Koch. (Nogueira, 1945:102)

O que mais então seria responsável pelo comportamento beligerante detectado nos pectários? Sem saída mais plausível, Oracy Nogueira respondeu com a indicação da tendência auto-afirmadora dos tísicos como elemento incitador da revolta. Neste encadeamento de idéias, um atributo explicava o outro, formando um círculo vicioso que não abria chances para análise acadêmica mais conseqüente sobre a conduta dos doentes dos pulmões.

\section{As Releituras}

A produção parcial ou integralmente memorialista não se fechou apenas no círculo dos infectados, ganhando foro nos debates públicos e nas reações pessoais. A recepção e o tratamento emprestado às obras que discorriam sobre os consuntivos incentivavam avaliações que fundiam interesses de toda sorte, aproximando o processo de leitura da história do pensamento e, neste contexto, evidenciando os vieses delineadores das imagens que o tecido coletivo associava aos tísicos.

Dentre os livros de tendência memorialista mencionados, nenhum outro obteve tanta aceitação pública quanto Floradas na Serra, tornando-se história narrada em quadrinhos e no rádio, no cinema e na televisão. O sucesso desse romance também fomentou a veiculação de críticas que, escudadas na medicina, na estética literária ou na experiência íntima com a enfermidade, nutriram um caloroso confronto entre os que 
admitiam a plausibilidade dos acontecimentos descritos por Dinah Silveira de Queiroz e aqueles que buscavam novos entendimentos sobre a vida dos consuntivos.

Além dos naturais elogios dirigidos à autora - alguns deles assinados por Waldomiro Silveira e Raquel de Queiroz, respectivamente tio e cunhada da escritora Floradas na Serra ganhou destaque na imprensa diária, abrindo oportunidade para que os clínicos nacionais discorressem publicamente sobre o comportamento dos doentes pulmonares.

O primeiro facultativo a utilizar dos jornais populares para focar o livro foi o Dr. Ulysses Paranhos, amigo de Dinah e um dos principais nomes da medicina brasileira no período. Mesmo alegando não compactuar com a discussão de "assumptos scientificos na imprensa profana”, o Dr. Paranhos enfatizou que, apesar das "pequeninas imperfeições” existentes no romance, Dinah Silveira de Queiroz tinha dado um passo definitivo na observação do cotidiano dos infectados, colhendo elementos comprovadores da corrupção moral imposta pela Peste Branca.

Após prolongar-se no reconhecimento dos desarranjos de personalidade produzidos pela tísica e na desqualificação dos recursos climatoterápicos, o médico concluiu:

O que nos impressionou seriamente no livro de Dinah foi a compreensão exacta da psycologia do tuberculoso, o conhecimento moderno dos complexos que se debatem no seu cerebro, suas tendencias sentimentaes e a mystica propria destes pobres doentes, tão curiosa e cheia de imprevistos para quem, christãmente, a estuda de perto. (Paranhos, 1939a:6)

Reações ao artigo assinado pelo clínico paulista não se fizeram por esperar. Transcorridos poucos dias desde a publicação do texto do Dr. Paranhos, o Campos de Jordão Jornal respondeu ao médico e à escritora, defendendo em primeiro lugar a proposta higiênica, reeducadora e curativa das casas de saúde localizadas na Serra da Mantiqueira e, na seqüência, lançando dúvidas sobre a deformação dos sentidos causada pelas toxinas liberadas pelo bacilo de Koch. Como recurso desqualificador das observações que o clínico tecera a partir do livro de Dinah, os jordanenses, nas páginas de um jornal local, buscaram questionar a veracidade literária, comentando: "Quem poderá affirmar observação, sem antes pensar que um romancista cria o que não observa e não póde explicar?” (Apud Paranhos, 1939a:3).

Além da resposta leiga, um único médico se fez presente nos jornais para contestar os postulados de autoria de Dinah e do Dr. Ulysses Paranhos. Como já foi visto, coube ao tisiologista joseense Souza Soares (1939) lançar as primeiras sementes de dúvida sobre a exclusividade bacilar no delineamento das 'atitudes dos tísicos' sendo que, por intermédio da Folha da Manhã, o especialista condenou abertamente a aceitação hipocrática da doutrina que reconhecia a determinação unicamente toxínica da ‘psicologia' dos contaminados. Para tanto, o clínico informou que a comunidade médica européia já se mostrava reticente em adotar tal posicionamento, buscando explicações complementares no campo da psicossociologia.

O Dr. Ulysses Paranhos não se conformou com a contestação assinada por seu par acadêmico, recorrendo novamente à 'imprensa profana' para expor sua estranheza frente às repercussões que tiveram suas 'despretensiosas palavras'. Com o intuito de 
emprestar maior vigor às suas idéias, o médico buscou apoio em Comte e Claude Bernard para reafirmar seu posicionamento, apesar de, neste segundo artigo, declarar que "nem tudo é absoluto" (Paranhos, 1939b:3), e por isso conhecer dignas exceções morais entre a irmandade dos tísicos.

Após mencionar nomes de santos e de artistas tuberculosos que fugiam à regra da poluição moral, o Dr. Paranhos sutilmente referiu-se ao clínico que o criticara algumas semanas antes e que, como tantos outros tisiologistas, havia se instalado na prefeitura sanitária do Vale do Paraíba para tratar de sua própria enfermidade pulmonar: “Actualmente está em S. José dos Campos alguém que se encontra neste caso. Sacrificou-se pelos seus doentes e, dentro de uma enfermaria, adquiriu o germe que the destruiu sua mocidade bôa e santa” (Paranhos, 1939b:3).

A discórdia batera à porta da Academia de Hipócrates. Por isso, a corporação médica abandonou sorrateiramente a arena pública, dando continuidade aos debates apenas por meio das páginas das revistas especializadas. Ainda em 1939, o clínicoassistente do Hospital Psiquiátrico do Juqueri, Dr. José Nascimento de Almeida Prado, cerrou fileira com o Ulysses Paranhos para confirmar os postulados expressos pelo seu colega. Seguindo esta opção, Almeida Prado reiterou a validade do princípio que indicava a ação tóxica do micróbio tuberculoso, concluindo que, afinal, a Peste Branca poderia funcionar como elemento aperfeiçoador do 'espirito humano', já que deu forma a espíritos nobres que influenciaram decisivamente a 'marcha da História':

Falem as grandezas musicais de Mozart, de Chopin, as inspirações poéticas de Casimiro, de Alvares de Azevedo, de Rodrigues de Abreu, as belezas literárias de Paulo Setubal (...). Dizem outros que as toxinas do bacilo de Koch, nas pessoas de temperamento místico, exaltaram essa tendência, elevando às vezes ao mais alto grau a piedade, à heroicidade de virtudes, às grandezas morais, à contemplação do Céu e honras dos altares. (Prado, 1939:457)

E depois de recitar os nomes santificados dos fimatosos, Teresinha do Menino Jesus, Luiz Gonzaga, Francisco Xavier, Francisco de Assis, Guy de Fontglan e Antoninho Marmo, o psiquiatra concluiu enfaticamente: "Se assim é, bendita tuberculose, bendito misticismo, bendita psicose; maravilha do Céu para edificação da humanidade!”.

Por seu turno, o Dr. Souza Soares (1940) continuou a bater-se contra os defensores dos descalabros comportamentais atribuídos à ação bacilar, elaborando um longo relatório sobre a bibliografia internacional que confirmava a recente fragmentação do posicionamento médico europeu. Apesar de não rejeitar o comportamento 'alterado' dos consuntivos, o tisiologista de São José dos Campos permaneceu como voz solitária até 1945, quando Oracy Nogueira inteirou-se das discussões, fazendo de sua dissertação de mestrado uma espécie de desdobramento dos postulados defendidos pelo médico consuntivo.

Ainda demoraria muito para os tisiologistas brasileiros desvencilharem-se da crença sobre a particularidade comportamental dos infectados. Mas, graças ao Dr. Souza Soares, a semente estava plantada.

No final das averiguações, nem a literatura de tendência autobiográfica, nem as Ciências Sociais e nem ainda as declarações registradas nos prontuários médicos pos- 
taram-se como canais questionadores da veracidade dos estigmas imputados aos tísicos. As tentativas elucidadoras do 'eu' mostravam-se convergentes, situando os pronunciamentos públicos e os depoimentos privados dos pectários como vozes disseminadoras das vertentes que fomentavam a diabolização e a discriminação coletiva das vítimas do Grande Mal.

Apesar de algumas observações elaboradas pelos próprios infectados negarem parcialmente a 'causação' toxínica das 'atitudes desajustadas', nenhum doente ousou desqualificar a multiplicidade de estigmas aglutinados sob a denominação de 'psicologia do tuberculoso'. Frente a este fenômeno, acredita-se que, mais do que produto dos empenhos institucionais em inculcar as idéias denegridoras da existência infectada, os próprios consuntivos enquadraram-se simbolicamente no modelo comportamental preconizado como exclusivo dos tributários da Peste Branca.

Recorrendo ao rol de terminologias utilizadas pelo sociólogo Erving Goffman (1975), supõe-se que os doentes do peito serviram-se de uma 'idealização negativa' de força e expressão histórica como 'fachada' para viabilizar o desempenho de papéis que, sincera ou cinicamente 'encenados', tinham como resultado a integração dos doentes no contexto social subjacente.

Em decorrência desse posicionamento, a sociedade como um todo e o agrupamento intelectual em particular utilizaram as declarações emitidas pelos contaminados para reiterar a validade e a precisão dos conceitos incorporados pela 'ciência moderna' e também para dimensionar a moléstia pulmonar e suas vítimas como símbolos maiores da dor e do sofrimento.

Abre-se assim a possibilidade de chegada a uma nova etapa na elaboração de uma História Social do Doente. Se as reações contra o ordenamento sanitário e os estigmas coexistiam com os esforços de definição do 'eu', os tuberculosos também buscavam formular estratégias conciliadoras com o tecido coletivo mais abrangente e, mediante estas ações, opor-se ao que era mais temido: a exclusão, sinônimo de morte social.

\section{NoTas}

1 Em um único caso houve variação desta fórmula, quando o paciente Oswaldo Penna (P. 1011) declarou que sua enfermidade teve início depois de tomar "muito sol em Santos”.

2 Vale lembrar que, quando no ano de 1954 a Companhia Cinematográfica Vera Cruz transformou em filme o romance de Dinah, a autora impôs que a personagem central da encenação fosse Lucilia e não Elza, interpretada pela atriz Cacilda Becker.

3 Ressalta-se que na segunda edição deste livro, tutelada em 1986 pela editora Atual, o autor reclamou para si os papéis de 'psiquiatra popular e antropólogo'. 


\section{0 \\ Os Caminhos da Vida e da Ciência}

Desde o momento em que o tuberculoso era assumido pelas malhas do isolamento, ficava patente para ele que o tempo perdera o valor de grandeza matemática para se equiparar a uma estranha espécie de medida biológica, na qual a aparência radiológica dos pulmões e a quantidade de bacilos contados em cada amostra de escarro analisada constituíam-se em índices determinadores do período em que a vida permaneceria estancada pelas normas sanitárias.

Dependentes do parecer médico, os pacientes vislumbravam a alforria institucional não só quando a cura ou o controle da infecção eram anunciados pelos especialistas, mas também quando o caso era avaliado como 'clinicamente perdido'. Isso porque a condição de doente terminal coagia as autoridades hospitalares a ganharem súbito ar de condescendência, abrindo oportunidade para que os moribundos - ou seus responsáveis - optassem entre a mudança para o pavilhão exclusivo dos 'quasemortos' e a transferência para o aconchego doméstico.

A decisão de empenhar os últimos momentos da existência em local distante do ambiente sanatorial é uma constante anotada em numerosos prontuários de fimatosos que certamente estavam cientes do pouco tempo de vida que lhes restava. Assim aconteceu com o operário Jairo Lemes Amaro (P. 874), um consuntivo de 22 anos de idade que permaneceu durante trinta meses na enfermaria de indigentes do Hospital São Luiz Gonzaga.

No transcorrer do período de isolamento, Jairo viu seu corpo minguar pouco a pouco: os boletins elaborados pela equipe de enfermagem registram que o paciente perdia peso, chegando a apenas 30 quilos, o que impunha uma imagem demasiadamente arruinada ao seu corpo, que atingia 1,76 metro de altura. Mais ainda, o tísico queixava-se diariamente de atrozes 'pontadas no peito' que não o deixavam dormir, sendo de pouca valia as injeções de morfina recomendadas pela clínica. Nestas condições, o enfermo percebeu que sua vida estava por um fio e, por isso, no dia 5 de abril de 1940, pediu alta "para falecer em sua casa em Jacareí", sendo seu rogo imediatamente atendido pelo Dr. Alvaro de Lemos Torres, diretor da casa de saúde do Jaçanã.

A mesma presteza institucional não tinha lugar quando o enfermo estava em vias de alcançar a cura ou pelo menos a estabilidade do processo patológico crônico. Contrariando os pedidos de dispensa formulados pelos pacientes em fase adiantada de recuperação, os tisiologistas tentavam estender o tempo de internamento, lembrando 
aos consuntivos que a condição sinuosa da Peste Branca aconselhava que mesmo os curados deveriam permanecer alguns meses sob observação hospitalar, para que ficasse comprovado o pleno equilíbrio das funções pulmonares.

A demora médica em conceder alta incitava os hóspedes convalescentes das mansões sanitárias a insistirem contra o prolongamento da reclusão. O lavrador Raphael Alexandrino da Silva (F. 2669) foi um dos tuberculosos assistidos pelo sanatório paulistano da Santa Casa que pediu dispensa logo após ser informado que estava próximo da cura, fato que justificou a seguinte nota clínica: "O doente não quiz permanecer por mais tempo no Hospital razão pela qual não se preve a durabilidade da cura”.

Retomar a vida livre e afastada dos ambientes 'entisicados' era o desejo comum a todos os pectários. Mas, seria isto viável para aqueles que momentaneamente haviam vencido o Grande Mal? A marca aviltante da moléstia levava as famílias dos enfraquecidos do peito a se mostrarem reticentes na hora de admitir o regresso do enfermo para o recinto doméstico. O receio de que o convalescente pudesse contaminar e corromper moralmente os sadios unia-se à duvidosa capacidade do infectado ganhar seu próprio sustento, resultando no adiamento máximo possível da reincorporação dos fimatosos nos seus círculos de amizade e parentesco.

É certo que os asilados, ao se desligarem dos sanatórios, já antecipadamente sabiam das dificuldades produzidas pela decisão de reingresso no universo dos sadios. As enfermarias estavam repletas de tísicos crônicos cujas histórias eram pontuadas pela frustração de pessoas que se viram rejeitadas pelos seus familiares, resultando em pedidos de readmissão hospitalar.

Dentre tantos casos semelhantes, encontra-se o da paciente Zulmira Gonçalves (P. 322) que, após ter sido premiada com alta clínica em "estado muito melhorado", voltou a residir com o marido e os filhos, no bairro de Pirituba. Porém, dois meses após ser liberada, Zulmira voltou ao Hospital São Luiz Gonzaga, informando que “sentia-se bem”, mas que desejava retomar seu leito na enfermaria porque "seu marido achou por bem mante-la afastada dos filhos menores".

Os constrangimentos gerados pela experiência íntima com a enfermidade e as desconfianças nutridas pelos sadios em relação aos infectados exigiam que os pectários buscassem escamotear o pretérito de doente do peito. O tuberculoso Antônio Olavo Pereira (1976) - irmão do editor José Olympio - depois de abandonar Campos do Jordão, evitava manter contato social com os seus antigos 'colegas', negando-se veementemente a declinar o nome da prefeitura sanitária onde permanecera por vários anos.

O empenho em atenuar as marcas da enfermidade impregnava também o cotidiano de Manuel Bandeira. Auxiliado por seu amigo e tisiologista Aloysio de Paula, o poeta aprendeu a realizar uma meticulosa 'toalete brônquica', momento no qual tentava expelir o catarro acumulado nos pulmões fibrosados pela tísica. Com esta prática que se repetia todas as manhãs, Manuel Bandeira sentia-se livre para sair à rua, sem receios de ser vitimado pela tosse copiosa que colocava em alerta seus parceiros de jornada intelectual (Paula, 1989).

Porém, não era fácil esconder a condição de quem um dia fora tributário da Peste Branca. O ditado popular que alertava "uma vez tuberculoso, sempre tuberculoso" colocava em suspeita todos aqueles que guardavam as marcas da corrupção pulmonar. 
Uma depoente, que exigiu sigilo sobre sua identidade, lembrou com lágrimas nos olhos a situação que viveu na infância, quando sua mãe recebeu alta de um sanatório jordanense. Ao retornar para sua residência, na cidade de São Paulo, a convalescente soube que seu marido havia fugido logo após receber o telegrama que informava sobre sua volta ao lar, deixando a filha do casal aos cuidados de uma vizinha.

Nesta condição, a enferma transferiu-se com sua criança para a cidade de Atibaia, onde alugou uma casa de fundos e passou a viver como empregada de uma fábrica local. Tudo corria bem para a consuntiva e sua filha até o instante em que um dos vizinhos especulou a menina sobre o passado materno, sabendo então que a inquilina havia vivido durante dois anos em Campos do Jordão. Ato contínuo, o temeroso indivíduo reuniu os moradores das proximidades, exigindo que a infectada abandonasse o bairro no prazo de 24 horas.

A verificação, no cotidiano, de situações como esta fazia com que os tísicos tentassem se proteger das eternas suspeitas por meio da apresentação de um documento comprovador do atual estado de saúde do fimatoso. O lavrador Pedro Celestino Filho (P. 1717), que em agosto de 1943 havia recebido alta, retornou ao Sanatório do Jaçanã para pedir um atestado clínico, alegando que carecia do relatório por ter se defrontado com “algumas dificuldades” para conseguir emprego. Em resposta, o Dr. Octavio Nebias redigiu a seguinte declaração: “Atesto que o Sr. Pedro Celestino Filho se encontra em recuperação pulmonar e apresenta uma imagem de condensação, tendo sido negativas as provas de laboratorio para diagnostico de tuberculose”.

A posse de uma carta confirmadora de que o portador encontrava-se 'curado' ou ‘em recuperação’ da tísica não representava qualquer garantia de colocação no mercado de trabalho. A desvalorização da mão-de-obra com passagem sanatorial resultava na convergência dos pectários para empregos com salários reduzidos, exigindo-se destes funcionários redobrados esforços produtivos em retribuição ao 'favor' que o patrão estava fazendo em contratar um doente do peito.

Cobrado talvez mais do que os seus companheiros sadios, o operário consuntivo via-se pressionado a aceitar qualquer proposta de emprego, mesmo nas atividades que eram desaconselhadas para os convalescentes que, em geral, deixavam de ser preparados pela medicina para retornar à rotina do trabalho em atividade compatível com seu estado de saúde.

Paralelamente aos arranjos que provessem as necessidades básicas, os egressos do sistema hospitalar aproveitavam a relativa liberdade de ir e vir para percorrer diferentes lugares à procura do remédio ou do milagre que os libertassem de vez do fantasma consuntivo. A confiança oscilante, às vezes rota, na capacidade médica de vencer a Peste Branca, coagia muitos enfermos a tentarem outras formas de tratamento pulmonar, sem, no entanto, abandonar as propostas terapêuticas fomentadas pela tisiologia.

Um antigo tuberculoso crônico confidenciou que, logo após receber alta de um sanatório jordanense, permaneceu por dois anos visitando médicos alternativos, farmacêuticos, massagistas, naturalistas, ervanários, padres, pais e mães de santo, benzedeiras, curadores e líderes espíritas, sempre buscando a mesma coisa: a 'cura definitiva' das cavernas pulmonares. 
Neste contexto, talvez seja o momento ideal para a pergunta: além da assistência prestada pela medicina alopática e da pálida esperança da ocorrência da 'cura espontânea’ alardeada pela clínica, quais eram as demais modalidades terapêuticas colocadas à disposição dos fimatosos, principalmente quando estes estavam distantes da vigilância nosocomial?

A primeira referência mencionada por vários entrevistados foram os almanaques distribuídos gratuitamente pelas farmácias e que alardeavam diferentes remédios contra a 'fraqueza pulmonar'. Nesses livretos, bem mais publicitários do que educativos, anunciava-se uma quantidade surpreendente de remédios curativos ou que pelo menos garantiam a energia suficiente para que os infectados superassem a anorexia produzida pela moléstia pulmonar: Biotônico Fontoura, Peitoral de Cereja do Dr. Ayer, Peitoral Anancahuita, Bromil, Sangue de Cavalo, Ferro Concentrado e Emulsão de Scott eram alguns dos produtos apresentados como 'poderosos auxiliares' no tratamento da tísica.

Junto aos exemplares nacionais, os almanaques estrangeiros também ganhavam aceitação, sendo que o Almanach Hachette, (1941:146) alardeou que a "cura certa da tuberculose” poderia ser alcançada mediante o uso de uma droga secreta, mas tão secreta que até mesmo o seu nome não podia ser declarado nas páginas do catálogo.

A certeza de que quanto mais remédios fossem utilizados, maior seriam as chances de recuperação da saúde impunha que os doentes buscassem novas esperanças nas práticas médicas atualmente consideradas alternativas. A homeopatia despontava como possibilidade enfaticamente lembrada pelos tributários da Peste Branca, inclusive porque eram freqüentes os pronunciamentos clínicos que pontificavam que a doutrina criada por Hahnemann reunia recursos suficientes para promover a "cura rapida de todos os tuberculosos”.

Dentre os vários específicos homeopáticos ministrados contra o Grande Mal encontravam-se a Pulmonina, do Dr. Alberto Seabra, assim como alguns preparados como o Phosphorus e a Calcarea carbonica, estes últimos indicados para a moléstia consuntiva desde o momento constitutivo do ideário homeopático.

A multiplicação de práticas alternativas expandia numericamente as promessas de cura, as quais eram vulgarizadas por meio de livretos preconizadores do princípio segundo o qual a tuberculose não era uma doença tão letal quanto a alopatia proclamava. A perspectiva negadora da veiculação microbiana da tísica tornou-se fonte de inspiração para vários estudiosos que, mesmo escrevendo no estrangeiro, encontravam ampla receptividade no Brasil.

Dentre tantos nomes invocados pelas testemunhas deste período, encontramse os do chileno Manuel Lazaeta Acharan (1933) e do argentino Jaime Scolnik (1940). No decorrer dos anos 30, estes personagens apresentaram-se como articuladores de novas doutrinas que, no final das contas, constituíam-se em cópias mal ajambradas do ideário vitalista vigente no início do século XIX.

Tanto para Lazaeta quanto para Scolnik, a causa primeira da enfermidade pulmonar encontrava-se na deterioração da parcela de alimentos ingerida mas não absorvida pelo organismo humano. O ‘apodrecimento’ das substâncias não aproveitadas produzia uma 'inflamação intestinal' que repercutia no funcionamento precário de todo o corpo e em especial do aparelho respiratório, podendo resultar inclusive no fenômeno 
que a medicina erroneamente denominava de tísica. Assim, para a cura da tuberculose sin médico ni farmacia, prescrevia-se uma dieta alimentar vegetariana que, baseada em frutas cítricas, nozes e avelãs, favorecia a rápida absorção orgânica da comida, purificando o sangue ao mesmo tempo que inibia qualquer disfunção pulmonar.

A aceitação das propostas curativas importadas incitou diversos estudiosos brasileiros a 'descobrirem' a solução final para o enigma sanitário. Dentre os vários pesquisadores nacionais que divulgaram versões explicadoras do mecanismo patológico, encontra-se o engenheiro e filósofo Roberto de Souza (1941-1947) que, ostentando diplomas expedidos pela Escola Politécnica e pela Faculdade de Filosofia, Ciências e Letras, ambas da Universidade de São Paulo, compôs uma série de relatórios sobre a Peste Branca, textos estes que, ainda nos anos 40, foram reunidos em livro.

Seguindo as conclusões da clínica alopática, Roberto de Souza informou que o bacilo de Koch constituía-se em um germe altamente infeccioso, mas pouco patógeno, daí estar presente na maior parte dos seres humanos, sem contudo produzir a moléstia em todos os contaminados. A diferenciação entre ‘indivíduo infectado' e 'indivíduo enfermo' permitiu ao engenheiro filósofo repetir o velho jargão segundo o qual "só é tuberculoso quem quer”, oferecendo a partir daí encaminhamento próprio para a terapêutica eficaz tanto para a moléstia consuntiva quanto para a terrível hanseníase. Eis o segredo do pesquisador Souza: uma 'alimentação racional', baseada em sais minerais, vitaminas essenciais, ácido fólico e extrato hepático garantiria vigor orgânico suficiente para a produção de anticorpos capazes de bloquear a invasão bacilar e também de expulsar as colônias bacterianas que povoavam o corpo dos consuntivos e dos leprosos.

As propostas que reduziam o Grande Mal à condição de doença de fácil prevenção e cura seduziam a população, tornando-a vítima indefesa dos aventureiros que queriam lucrar com o império da tisiofobia. Os esforços despendidos pelos vendedores ambulantes que comercializavam em praça pública compostos apresentados como restauradores da saúde pulmonar chegavam às raias do humor negro. Em um destes casos, o paulistano jornal Folha da Noite, de 14 de outubro de 1932, convocou a polícia para dar voz de prisão a um "camelot” que passava os dias nas calçadas da Avenida São João, anunciando em altos brados as qualidades medicinais do sabão inglês produzido por um certo Dr. Rolls Royce, sendo que, segundo o vendedor, tal mercadoria curava "desde callos até tuberculose galopante".

Além das drogas fornecidas pelas diversas vertentes médicas e também pelos exploradores dos medos coletivos, a tragédia íntima da tuberculose impunha que os fimatosos buscassem alcançar a pureza do corpo e da alma por meio da intervenção divina. A aproximação histórica entre o espiritismo e a homeopatia situava a tenda espírita como extensão do gabinete hahnemanniano, fazendo com que o credo religioso e a medicina alternativa afluíssem para a promessa de cura rápida de todos os pectários conversos a um só tempo às prédicas de Allan Kardec e aos ensinamentos de Samuel Hahnemann.

A doutrina católica romana, bem mais do que o espiritismo, pregava que a cura dos tísicos poderia ser alcançada por intermédio da misericórdia de Jesus Cristo e de todos os santos. Em resultado, o estado de São Paulo contou com inúmeras capelas para onde se dirigiam os infectados à espera do milagre salvador, ganhando prestígio a 
'igrejinha' construída por ordem de Antonio da Rocha Marmo, em terreno adquirido por seus pais, em São José dos Campos. Um informante esclareceu que a existência de um santuário em homenagem ao menino Antonio tornou regra que os doentes que rumavam para a prefeitura sanitária do Vale do Paraíba se detivessem por alguns instantes no pequeno recinto sagrado, "limpando a alma para buscar a melhora da saúde com os médicos".

Apesar da proliferação dos centros religiosos paulistas que atraíam a presença dos fracos do peito, nenhum outro local granjeou tanta fama quanto a igreja matriz da vila de Poá, área então pertencente ao município de Mogi das Cruzes e localizada a cerca de $35 \mathrm{Km}$ da cidade de São Paulo.

No ano de 1935, o sacerdote holandês Eustáquio Van Lieshout foi designado para coordenar os serviços pastorais naquela comunidade, imediatamente ganhando prestígio como médico e farmacêutico improvisado que curava todos os adoentados que o procuravam. A declarada devoção do padre Eustáquio à Nossa Senhora de Lourdes - santa de invocação contínua por parte dos consuntivos - estimulou os boatos que apontavam o filho da Ordem do Sagrado Coração como responsável pelas 'curas milagrosas' de diversos pectários, fato que instigou ainda mais a presença de tuberculosos na pequena Poá.

A agitação que tomou conta do núcleo religioso chamou a atenção da polícia getulista que, no final da década de 30, designou o médico Aguiar Whitaker (1944) para averiguar de perto o que vinha acontecendo na paróquia comandada pelo padre holandês. O Dr. Whitaker, por sua vez, convocou meia dúzia de 'secretas' para o acompanharem até o local dos acontecimentos, misturando-se aos peregrinos para descobrir a verdade sobre os milagres.

As descrições elaboradas pelo médico da polícia são impressionantes: a vila que contava com pouco mais de uma centena de habitantes era tomada diariamente por cerca de 10 mil visitantes, sendo que a região transformara-se em um "acampamento de barbaros”, onde paralíticos e portadores de moléstias infecto-contagiosas engalfinhavam-se na disputa pela água benzida pelo padre Eustáquio.

Curioso para saber com precisão o número de tísicos que cotidianamente compareciam àquele centro de milagres, o Dr. Whitaker manteve-se indeciso, resignando-se em tecer um paralelo entre a matriz de Poá e a basílica francesa de Nossa Senhora de Lourdes, assinalando que, no caso do santuário europeu, pelo menos um terço dos peregrinos era composto por doentes pulmonares.

Rejeitados por muitas das pessoas íntimas, aviltados no emprego e espreitados pela polícia, muitos convalescentes sentiam-se verdadeiros mendigos que esmolavam solidariedade e saúde. Não, não era tarefa fácil o retorno e permanência dos pectários para o mundo que lhes fora minimamente acolhedor até o momento em que a 'magrinha' se apoderara de suas existências. "Oh! desespero das pessôas tísicas...”, esta sentença de desabafo foi pronunciada na segunda década do século passado pelo fimatoso Augusto dos Anjos e ajusta-se com perfeição ao sentimento de muitos personagens consuntivos que tentaram reingressar na pátria dos sadios, resultando no acréscimo de novas mágoas às biografias dos tísicos. 
Como resultado da discriminação que feria os tuberculosos que haviam abandonado o isolamento, um número significativo de doentes optou pelo regresso ao hospital no qual haviam tratado dos pulmões ou pelo estabelecimento de residência definitiva nas estações climatoterápicas do estado de São Paulo.

Uma consuntiva que, no início da década de 40, foi dispensada de uma casa de saúde joseense, comemorou o fim do cativeiro rumando para o interior de Minas Gerais, onde residiam seus familiares. Transcorridos poucos meses do regresso ao seu município de origem, a fimatosa decidiu retornar à prefeitura sanitária do Vale do Paraíba, esclarecendo em seu depoimento oral que:

\begin{abstract}
Lá em casa em fiquei sozinha num quarto e continuei com os mesmos regulamentos do sanatório: guardava repouso, tomava remédios, deixava as janelas abertas e fazia boa alimentação. Mas eu não me sentia bem, nem física, nem moralmente. As amigas que eu tinha antes de vir para São José, elas se afastaram de mim. Quando eu saia à rua e elas me viam, essas amigas me cumprimentavam de longe, trocavam de calçada porque não tinham coragem de se aproximar. Eu me sentia muito isolada. Depois de ver tudo isto, eu resolvi voltar para o convívio dos doentes pois aqui em São José eu me sentia bem, tinha muitas amizades. O sanatório era minha casa, onde eu gozava de toda liberdade, ninguém tinha medo de ninguém. De tanto insistir, papai me trouxe de volta e eu nunca mais saí de São José.
\end{abstract}

O convívio íntimo com a Peste Branca e o tratamento discriminador promovido contra os fimatosos permitiu que se processasse uma surpreendente inversão de expectativas na trajetória dos infectados. Primeiramente, a reclusão sanitária era percebida como estratégia confiscadora da autonomia individual, levando os pectários a se sentirem prisioneiros das instituições médicas. Em seguida, a alta clínica era aguardada ansiosamente, pois sob esta rubrica encontravam-se as duas maiores ambições acalentadas pelos fimatosos: a melhora ou mesmo cura dos pulmões e o encerramento do tempo de exílio. Por fim, as malogradas tentativas de recolocação dos consuntivos na rotina dos sadios fazia com que os infectados se reconhecem definitivamente como agrupamento diferenciado.

Em conseqüência, para muitos dos tuberculosos, a condição de liberdade só poderia existir entre os iguais na doença, nos estigmas e nos sonhos. Desdobramento natural desta decisão era a escolha das áreas de concentração dos tributários do Grande Mal como espaços próprios para a reorganização das vidas para sempre marcadas pela Peste Branca.

As histórias que seguem constituem versões possíveis da (re)invenção da vida sob a égide da tuberculose.

\title{
DONATO: A VIDA NO ISOLAMENTO
}

O Hospital São Luiz Gonzaga entrou em funcionamento a partir da manhã do dia 3 de julho de 1932. Quatro dias depois, um homem de estatura mediana e com peso pouco abaixo do ideal bateu à porta do sanatório, buscando tratamento para a tubercu- 
lose fibro-caseosa que se disseminara pelos seus dois pulmões e que o atormentava há "um ano e pouco".

Admitido como hóspede indigente do nosocômio, o pectário deixou os dados necessários para o registro: seu nome era Donato Visosky (P. 738; 3466; 6673; 11886), nascido na Lituânia, no ano de 1902. Depois de perder o pai na Grande Guerra e ele próprio ter quase morrido durante a pandemia gripal de 1918, o paciente migrou com parte de seu clã para o Brasil, encontrando emprego de colono numa fazenda localizada no oeste bandeirante. Foi no eito que pela primeira vez Donato percebeu os sintomas iniciais da tísica:

depois de estar bastante suado pelo trabalho de enxada, apanhou chuva. Começou a sentir dores em todo o torax, tossindo muito com escarro que era a principio branco e depois amarelo. Teve uma hemoptise; saiu-lhe pela boca sangue de côr vermelha; acha que saiu mais ou menos um litro de sangue. Emagreceu gradualmente, sentindo tambem suores nocturnos.

A fraqueza que se instalara no corpo enfermo exigiu que o imigrante suspendesse suas atividades no campo e rumasse para a cidade de São Paulo, onde encontrou assistência na 5aㅡ Enfermaria da unidade central da Santa Casa de Misericórdia, pavilhão onde eram isolados os pacientes portadores de patologias infecto-contagiosas. $\mathrm{O}$ tuberculoso permaneceu internado na casa de saúde por cerca de cinco meses, sendo que no final deste tempo pediu "alta por conta propria”, vivendo a partir de então "muitos mezes fora do hospital”.

O intervalo de tempo que o pectário permaneceu afastado do isolamento sanitário não ficou claro, supondo-se não ter sido superior a um ano. Neste período, o tuberculoso buscou encaixar-se nas malhas da metrópole, encontrando trabalho em uma fábrica de vidro e alugando uma vaga numa pensão localizada no bairro do Brás. Mas, mesmo apresentando “estado bem disposto e corado”, Donato preferiu voltar para o abrigo hospitalar. O que teria acontecido para que o operário escolhesse este encaminhamento para sua vida? Ninguém sabe, mas provavelmente o fimatoso, como muitos outros, não suportou o peso da tuberculofobia que impregnava os comportamentos coletivos, encontrando no sanatório um refúgio amenizador da solidão imposta aos doentes do peito.

Os exames clínicos aos quais foi submetido o paciente Donato Visosky logo comprovaram que ele pertencia ao grupo dos tísicos crônicos, sendo que seus exames de escarro e de suco gástrico indicavam uma sucessão de "negativos" e "positivos" que, ao mesmo tempo que confundiam as conclusões clínicas, também ofereciam um rumo indefinido para a vida do operário lituano. Em conseqüência, o paciente alternava extensos períodos de equilíbrio orgânico com momentos críticos, ora sendo consumido por “abundante hemoptise”, ora padecendo de "sufocação por falta de ar”, ou ainda por "punhaladas no pulmão direito”.

Neste clima de incertezas, Donato encontrou ocupação no sanatório, tornandose auxiliar de laboratório a partir de junho de 1933. O cotidiano do pectário parece que acompanhou a morosidade típica dos ambientes de cura até outubro de 1937, quando o doente foi convocado para o exame dirigido por uma junta de tisiologistas composta 
pelos Drs. Fleury de Oliveira, Octavio Nebias e João Grieco. Realizada a perícia, os especialistas anotaram no respectivo prontuário que o paciente apresentava "melhora radiologica discreta”, fechando o relatório com a seguinte observação: "vai continuar na mesma”. Continuar na mesma: estranha sentença premonitória. Quando em fevereiro do ano seguinte Donato recebeu alta clínica, ele já havia feito acertos para permanecer residindo no sanatório, não mais como paciente, mas sim como funcionário da Santa Casa. Estabelecida estratégia própria para fugir às dificuldades de permanência em um hospital sempre carente de leitos, o infectado continuou a ocupar uma vaga na enfermaria dos indigentes, mantendo-se assim pelos anos seguintes e sempre apresentando resultados contraditórios nos exames avaliadores da presença do bacilo de Koch em seu organismo.

A rotina diária obedecida por Donato começou a sofrer alterações a partir dos primeiros meses de 1947, quando o pectário - já classificado como 'técnico de laboratório' - passou a se queixar de uma "dor de estomago" que teve continuidade na "perda do apetite e emagrecimento acentuado".

Passados 15 anos desde sua entrada no Hospital São Luiz Gonzaga, o fimatoso tornou-se titular de um novo prontuário, documento no qual foram registrados momentos cruciais da vida do tuberculoso. Isto porque, no mês de junho, Donato foi submetido a uma apendicectomia e logo em seguida a uma outra operação, desta vez para amenizar o desconforto provocado por úlceras intestinais. Colocado em repouso na enfermaria, o paciente "tossiu durante 3 dias", fato que levou ao rompimento dos pontos cirúrgicos e à abertura do corte operatório, dando início a uma eventração. Muito mais do que a tísica, a associação destes eventos colocou Donato bem perto da morte.

Apesar do acidente pós-operatório, o lituano recuperou-se em pouco tempo, reassumindo as tarefas de funcionário do nosocômio em setembro de 1947 e permanecendo nesta categoria por quatro anos consecutivos, quando uma "forte gripe acompanhada de escarros com laivos sanguineos" fez com que o consuntivo voltasse à posição formal de hóspede da mansão da saúde. Naquele momento, Donato Visosky já havia recebido um grande número de unidades de estreptomicina, mas nem mesmo tal medicamento conseguiu restabelecer a saúde do técnico de laboratório que, somando 49 anos de vida, passou a reclamar com maior insistência das dificuldades respiratórias causadas pela moléstia pulmonar.

O novo período de tratamento do enfermo prolongou-se até fevereiro de 1953. Alguns meses antes, o paciente/funcionário havia sido requalificado pelo Instituto de Aposentadoria e Pensões dos Comerciários - órgão que mantinha convênio previdenciário com os servidores da Santa Casa - como "sócio aposentado por invalidez”, fazendo jus ao benefício mensal correspondente a $75 \%$ do valor do salário mínimo vigente. Um novo momento de tensão se abria para o tuberculoso: aposentado do serviço hospitalar e próximo de receber alta médica, qual seria o encaminhamento a ser dado a sua pessoa?

As anotações e bilhetes que foram preservados junto ao terceiro prontuário com o nome de Donato Visosky oferecem algumas pistas sobre as tentativas engendradas pelo setor de Serviço Social da Santa Casa para encontrar colocação para o paciente diferenciado. O registro em uma folha avulsa do número do telefone de uma sobrinha 
do pectário abre a possibilidade para se pensar que o nosocômio buscou aproximar o tísico de seus parentes mais próximos, hipótese que talvez ganhe comprovação numa frase lançada no mesmo documento: "o Donato não quiz se aproximar de seus familiares e raramente sai deste Hospital".

Nesse contexto, parece que os próprios médicos da Santa Casa mantinham relações amistosas com o hóspede mais antigo do sanatório. O tratamento "o Donato" repete-se em vários registros, insinuando os laços de familiaridade que uniam o tuberculoso à equipe hospitalar. Coube aos próprios clínicos decidir o destino de Donato, permitindo que o doente continuasse vivendo na casa de saúde do Jaçanã, ainda sob a condição de funcionário da instituição. Para tanto, o Dr. Octavio Nebias redigiu o seguinte bilhete, destinado ao tisiologista encarregado do tratamento do técnico de laboratório: "Ayrton! Pode dar alta regular pois o Donato volta outra vez a ser empregado do Hospital. Envie ao serviço de triagem para matricular”.

Os acertos destituídos de formalidade burocrática permitiram que o tuberculoso continuasse hospedado no Sanatório do Jaçanã pelo resto da sua vida. Em fevereiro de 1962, quando ainda seus exames mostravam-se positivos para o bacilo de Koch, Donato sofreu uma nova crise respiratória, agravada pela existência de "úlceras duodenais sem possibilidade cirurgica". Recolocado na teia hospitalar como paciente financiado pelo IAPC, o tísico passou a ocupar oficialmente uma cama na enfermaria do nosocômio, aí permanecendo até a manhã do dia 22 de novembro de 1964, quando chegou a óbito, sendo declarado como causa mortis um "processo ulceroso crônico".

Donato Visosky viveu 62 anos, sendo 32 deles como hóspede do Hospital São Luiz Gonzaga. Sua história registrada em quatro prontuários diferentes constitui-se em caso extremo do infectado que não suportou retornar ao território dominado pelos sãos, optando pelo prosseguimento da vida em companhia de seus iguais na enfermidade. O isolamento voluntário fez do sanatório o lar definitivo do contaminado, assim como os personagens institucionais ocuparam o espaço deixado em branco pelos parentes do lituano. Como resultado, a história de vida do paciente confundiu-se com a história do hospital especializado da Santa Casa, que sobreviveu apenas mais quatro anos após o falecimento do tuberculoso Donato.

\section{Raquel e Antonio: a VIDA na EstaÇão de CURA}

Após permanecer 21 meses isolada no Sanatório Ruy Dória, em janeiro de 1945, a consuntiva Raquel Pereira foi forçada a abandonar o exílio hospitalar pelo fato de sua família não dispor de recursos para custear por mais tempo seu internamento na casa de saúde joseense. Nesta situação, a angustiosa experiência de visitar sua cidade natal e de se perceber marginalizada pelo seu antigo círculo de amizades somou-se ao namoro firme com um enfermeiro que já havia sido tuberculoso, resultando na decisão de permanência da infectada em São José dos Campos, onde passou a repartir residência com uma amiga, também tributária da Peste Branca. 
Raquel permaneceu em tratamento com o Dr. Ruy Dória por mais três anos, alcançando 'cura clínica' em 1948, quando contava 24 anos de idade, cinco dos quais vividos na estância sanitária. Durante todo este tempo, a fimatosa contou com o apoio perseverante de Antonio, seu namorado e enfermeiro que, treinado nos serviços hospitalares, tornou-se uma espécie de tisiologista improvisado, ensinando a pectária a evitar quaisquer excessos, incluindo aí desde trocas de beijos até caminhadas desnecessárias pelo terreno da estação climatoterápica.

O discreto rompimento dos elos familiares tornou-se um fator coadjuvante no reforço dos laços sentimentais que uniam Raquel e Antonio. Quando o Dr. Dória declarou a depoente curada das lesões pulmonares, o casal imediatamente marcou a data do casamento, o qual se realizou na igreja matriz de Aparecida do Norte, momento no qual os progenitores dos nubentes se encontraram pela vez primeira.

"Eu me readaptei à sociedade porque não sai daqui". Com esta frase, Raquel deixou claro que ela e o marido estavam conscientes de que seria praticamente impossível encetar a vida a dois longe do ambiente de concentração dos tuberculosos. As 'cidades enfermas' ofereciam o indispensável sentimento de segurança para os fracos do peito que, além da disponibilidade de serviços médicos especializados, esperavam compartilhar de um contexto social em que a intensidade dos estigmas contra os infectados fosse bem menor do que em outras regiões do país.

O casal enraizou-se na estação de cura de São José dos Campos. Para Raquel e seu marido, a felicidade só se concretizaria quando a união frutificasse em filhos, de nada adiantando os conselhos hipocráticos que desestimulavam a gravidez no grupo de mulheres convalescentes. Em continuidade, menos de um ano após o enlace matrimonial, Raquel deu à luz uma criança que sobreviveu apenas alguns poucos dias, acidente que abriu as portas para que a frustrada mãe entendesse o óbito do primogênito como terrível legado da enfermidade pulmonar.

Entre o medo de gerar uma criança fraca ou mesmo consuntiva e frustrar o desejo do casal em povoar a casa de crianças, Raquel preferiu arriscar uma nova gravidez , fato que ocorreu poucos meses depois do seu primeiro parto. Desta vez, Antonio se encarregou de ministrar um tratamento paralelo ao que o Dr. Ruy Dória havia indicado à gestante, aplicando-lhe doses diárias de soro intravenoso, assim como drogas vitamínicas que, segundo Raquel, foram responsáveis pelo nascimento, em maio de 1950, de um “menino forte” e, nos anos seguintes, pela chegada de mais três crianças robustas.

Apesar da concretização do intento de ser mãe, Raquel nutria uma guerra íntima e solitária contra o fantasma da Peste Branca. A suposição de que o tisiologista que atestara sua cura houvesse se enganado ou que ela tivesse uma recidiva do Grande Mal fazia da depoente uma mulher sempre cautelosa no trato de seus rebentos:

Quando nasceram meus filhos eu sofria muito porque tinha uma insegurança muito grande. Eu tinha medo de beijar meus filhos no rosto. Eu achava que, de repente, eu poderia ser uma tuberculosa crônica daquelas que nem sente que está doente. Isto me aterrorizava, eu tinha medo de infectar minhas crianças...

A mulher que desconfiava de seu próprio estado de saúde sofria calada, não compartilhando seus receios nem mesmo com o marido, justificando seu laconismo 
como medida para "não impressionar" o enfermeiro. Para a ex-consuntiva, qualquer evento que lembrasse a possibilidade de reinfecção mostrava-se como anfiteatro da tragédia, ampliando suas angústias e exigindo estratégicas dissimulações:

Quando eu pegava um resfriado, uma gripe que me fazia tossir muito, eu me isolava das crianças. Eu tinha um medo medonho (...). Quando eu tinha tosse de gripe, eu deixava meus filhos num quarto e eu me isolava num cômodo localizado no fundo do quintal. Quando me dava ataque de tosse, eu punha um cobertor na boca e tossia escondido, para o meu marido não ouvir que eu estava tossindo. Eu tinha medo que o Antonio ficasse pensando que eu estivesse doente outra vez.

O trauma resultante da experiência com a fraqueza pulmonar e seus desdobramentos fazia com que Raquel acalentasse uma percepção contraditória da ameaça infecciosa. Assim, no momento em que já era mãe de três filhos e que a estreptomicina era largamente utilizada pela medicina nacional, a depoente acreditava que a tuberculose havia ganho o contorno de 'doença benigna porque facilmente curável'. Ao mesmo tempo, entretanto, Raquel confidenciou que selou um pacto com o Deus católico: se o Senhor a preservasse da reinfecção até que o mais jovem de seus rebentos atingisse a idade de 10 anos, ela não mais lutaria contra a Peste, entregando-se passivamente à doença, caso a moléstia voltasse a se instalar em seu organismo.

Em nenhum momento a prole de Raquel e Antonio denunciou sinais de contágio kochiano. A vacinação e as seguidas revacinações das crianças com BCG e a recorrência a clínicos gerais e especialistas no tratamento dos pulmões, nas ocasiões em que os filhos apresentassem qualquer alteração da saúde, foram as armas utilizadas pelos pais que temiam que a 'bruxa seca' atacasse seus frutos.

\section{Florbela: a herança da CAUTELa}

Florbela é uma docente universitária que pouco contato manteve com a mãe tuberculosa, falecida na primeira metade da década de 30, quando a depoente contava poucos anos de idade. Convidada para contar sua história, a simpática professora mostrou-se reticente em atender o pedido, protelando as informações por mais de um ano. Finalmente, 'de algum lugar na Montanha [Campos do Jordão], no Outono de 1991’, Florbela presenteou o pesquisador com um punhado de versos autobiográficos.

O poema é o seguinte:

O que se herda?

$O$ que se adquire?

Não corra. Não beba nada gelado.

Olhe o sol. Saia da chuva.

Sereno faz mal. Não pode, está ventando

Fecha a janela. Tem corrente de ar.

Leve o casaco. Ponha meia.

Descalça: Nunca.

Assim sem sol, sem chuva, sem sereno

sem vento consegui crescer.

Com óleo de fígado de bacalhau, 
com emulsão de Scott, com mel, gemada, xarope e vitamina

Cheguei até menina.

Raquítica diziam uns

Miudinha os parentes mais

condescendentes. Mignon

os mais sofisticados

Pobrezinha, também, com mãe doente

em voz de sussurro e acusação:

Tuberculosa - sabe, Bacilo de Koch!

Carreguei a culpa e tive um quarto só para mim.

água fervendo em toda louça

Afinal, não dá para arriscar.

Depois de algumas leituras e tenra sapiência

Fiz versos de condenada.

Aos 18 anos me preparei.

Pensava: vai ser tão romântico!

Depois

Por razões. Mais de mil. Saí de casa.

Atirei-me ao sol, a chuva, ao vento

Aos serenos da madrugada. Aos gelados

Janelas abertas. Descalça. A garoa de São Paulo!

Provoquei. Candidatei-me a T.B.

e até fiz uma excursão para Campos do Jordão.

Floradas na Serra. A Montanha Mágica.

e por razões misteriosas e inacreditáveis,

Sempre fui uma pessoa saudável

mais dada aos suspiros que aos espirros

Mas mesmo assim, quando me casei

alguém aterrorizado da família,

aterrorizado ou terrorista?

me chamou de lado e disse:

Você contou para ele?

Contou o que?

Que sua mãe morreu tuberculosa!

Meu Deus, esquecí!

Contei, casei, tenho filhos e netos

e ainda não morri (até já fui à Suíça!)

Tuberculose, pode ainda ser,

nunca se sabe! É uma sina,

um estigma, para alguns

quase uma nódoa.

Há doenças imorais.

Enfim, vou vivendo $e$

pertenço a algumas minorias

quase resgatadas -

filha de tuberculosa

e canhota.

Uma historinha, senhor Claudio, esta verdadeira. 
Os filhos dos tuberculosos podiam não herdar a doença do peito, mas certamente tornavam-se herdeiros dos estigmas e da aceitação reticente que um dia havia ferido seus progenitores contaminados. A tísica disseminava suas imagens sobre a família em que havia infectado e, de forma surpreendente, afetava a trajetória de vida daqueles que pertenciam à linhagem dos tuberculosos.

\section{as 'Maravilhas da Medicina' e os Comportamentos Sociais}

Enquanto os consuntivos e seus descendentes compunham suas sagas pessoais, a medicina empenhava recursos no preparo do quimioterápico específico contra a Peste Branca. As pesquisas patrocinadas pelos consórcios que uniam os governos das nações mais ricas do mundo com os laboratórios interessados em garantir substanciais lucros por meio do monopólio comercial dos novos medicamentos impuseram um ritmo acelerado aos trabalhos médico-farmacêuticos, resultando em descobertas em série.

Comprovada a eficiência terapêutica das drogas recém-preparadas, estas eram anunciadas de forma sensacionalista à comunidade dos especialistas e aos leigos, transformando a produção científica em um espetáculo público que apresentava os medicamentos como 'milagrosos', ‘espetaculares', ‘100\% eficientes' e ‘sem qualquer contra-indicação’. Era o que os livros de divulgação científica costumavam denominar de as "maravilhas da medicina" que, ao proclamar a positividade do saber médico, prometiam um futuro sem doença e sem dor.

Após o advento das sulfamidas, em 1935, e da penicilina, em 1943, a terapêutica específica contra a tuberculose se mostrava como desafio próximo a ser transposto. A droga que colocaria fim à Peste Branca como ‘doença misteriosa’ dominava as especulações médicas, chegando até o Brasil na figura do discreto professor Otto Bier (1944).

Empolgado com as recentes 'conquistas da ciência', o então diretor do Instituto Butantã concluiu mais um de seus manuais médicos, deixando implícito nas páginas deste livro que, em pouco tempo, a Humanidade teria a sua disposição um remédio com potencialidade curativa da tuberculose. O Dr. Bier tinha motivos para isto: boa parte da comunidade científica estava depositando grandes esperanças na capacidade terapêutica de uma variedade de sulfona que vinha sendo estudada nos Estados Unidos e que havia demonstrado significativa ação bacteriostática em relação ao agente biológico causal da tuberculose.

Enquanto o mundo apostava na iminência da descoberta, desde que a Segunda Guerra Mundial se iniciara, os Estados Unidos adotaram a política de atrair para o seu território os principais expoentes da intelectualidade européia, engajando os cientistas nas áreas diretamente relacionadas com os 'esforços de guerra'. Neste contexto, a Peste Branca ganhou especial atenção, sendo destacadas várias equipes de pesquisadores para estudar as possíveis soluções para a doença infecto-contagiosa mais disseminada do planeta.

As diversas equipes de cientistas empregadas no deciframento da Peste Branca contavam com uma seqüência de 'peças soltas' que falhavam no encaixe para explicar as possíveis estratégias destruidoras do bacilo de Koch. Os procedimentos tradicio- 
nais de pesquisa beiravam a inocuidade, pois, se permitiam a formulação de várias drogas que aniquilavam o micróbio, igualmente afetavam as cobaias contaminadas, levando-as ao óbito mais rapidamente do que o próprio germe tísico. Por isso, alguns cientistas de renome buscaram se afastar das seguras hipóteses ditadas pela biologia e pela química, enfronhando-se pelo ‘caminho noturno’ da ciência, definido pelo Prêmio Nobel François Jacob (1984) como a operação em que "o pensamento caminha através de vias sinuosas, de ruelas tortuosas, o mais das vezes sem saída”.

Assim, entre o romantismo aventureiro de se confrontar com o desconhecido e o cálculo frio da concorrência acadêmica e ideológica, em fins de 1944, o médico russo naturalizado norte-americano Selman Waksman anunciou a descoberta da estreptomicina, uma droga elaborada a partir da cultura de uma variedade de fungo denominada Streptomyces griseus.

Financiado pela Merck Company, o Dr. Waksman foi imediatamente acusado por seus colegas de ter se apropriado das conclusões de outros cientistas sem tê-los mencionado em seus relatórios. Mesmo assim, no primeiro dia de novembro de 1945, momento em que os Merck Laboratories iniciavam a produção comercial da droga, o Dr. Waksman dirigiu-se ao Committee on Military Affairs do senado americano para anunciar oficialmente que a Peste Branca estava prestes a ser debelada.

A informação sobre a descoberta da estreptomicina chegou ao Brasil logo no primeiro semestre de 1945, sendo recebida com indisfarçável desconfiança pelos enfermos que já haviam se habituado a conviver com os boatos que, periodicamente, criavam falsas esperanças por meio do anúncio da criação de uma quimioterapia específica contra a tuberculose. Identificando-se com vários outros registros de antigos pectários, uma depoente declarou:

Em 1945 eu tinha 20 anos e estava certa que em pouco tempo iria morrer. Em junho ou julho daquele ano um médico me disse que nos Estados Unidos um judeu russo tinha inventado a estreptomicina. Quando ele me falou aquilo, eu logo achei que fosse mais um notícia falsa mas, em 1948, eu já estava totalmente curada, as cavernas tinham cicatrizado, porque eu usei o remédio. Eu me lembro que naquele tempo a estreptomicina era cara. Minha família fez uma 'vaquinha' e mandou importar o remédio dos Estados Unidos. Aí eu fiquei boa.

Nos anos seguintes a 1945, outras drogas somaram-se à estreptomicina no combate à tuberculose, sendo as principais delas o ácido para-amino-salicílico (PAS), a tiosemicarbazona (tb-1) e a hidrazida de ácido isonicotínico (Isonazida). A escassez destes fármacos no território brasileiro tornou-os fonte de alta lucratividade no mercado negro, permitindo que os doentes mais abonados fizessem uso excessivo e muitas vezes desprovido de acompanhamento clínico. Em conseqüência, a medicina defrontou-se com uma nova categoria de pacientes, representada pelos que ficaram com a audição comprometida como seqüela dos medicamentos utilizados e por aqueles que tinham sido infectados por colônias bacilares que já haviam se tornado 'resistentes' às novas drogas.

De qualquer forma, a utilização combinada das várias drogas anti-consuntivas promoveu o decréscimo dos óbitos creditados à tísica nos grandes espaços urbanos. Na cidade de São Paulo, por exemplo, a taxa de mortalidade pela tuberculose em cada 100 mil habitantes refluiu de 133,8 em 1940, para 34,4 dez anos depois. 
Em meados da década de 50, os Centros de Saúde iniciaram a distribuição gratuita dos quimioterápicos apropriados para o combate à Peste Branca, contribuindo ainda mais para o rebaixamento dos índices de mortalidade pela moléstia consuntiva, especialmente entre os grupos mais pobres da população.

O resultado da aplicação maciça dos novos medicamentos foi não só a cura da maior parte dos infectados pelo bacilo de Koch como também uma profunda crise que feriu de morte as instituições e a especialidade médica relacionadas com o tratamento dos doentes do peito. A maior parte dos sanatórios que atendiam os tuberculosos resistiram no máximo por mais uma década após 1945, encerrando suas atividades ou, mais freqüentemente, redefinindo-se como hotéis, casas de repouso, asilos para inválidos ou hospitais gerais.

Os tisiologistas, por sua vez, perceberam-se subitamente deslocados profissionalmente, sendo obrigados a encetar novo treinamento especializado, já que os ‘tuberculosos residuais', que se mostravam insensíveis à ação dos novos medicamentos, eram em número reduzido para permitir a sobrevivência de uma área específica da medicina. Por isso, muitos dos antigos especialistas na Peste Branca voltaram-se para a clínica geral ou então, como fez o Dr. Euryclides Zerbini, permaneceram na área da cirurgia torácica, transferindo seu interesse para as pesquisas cardiológicas. O Dr. Eduardo Etzel foi um dos médicos de sanatório que aparentemente distanciou-se muito de sua antiga atividade, ganhando reputação como clínico psiquiatra e, nas últimas décadas como profícuo estudioso da arte brasileira.

O ‘triunfo da ciência’ e o ocaso da especialidade tisiológica não significou, entretanto, o encerramento da estigmatização coletiva dos doentes do peito. A rejeição médica - pelo menos em nível formal - da existência de uma 'psicologia' exclusiva dos tuberculosos e o emprego de novas estratégias de cura e prevenção da moléstia não implicaram em reformas imediatas nos códigos de relacionamento entre os sadios e os enfermos.

O fato dos comportamentos coletivos sofrerem alterações segundo um ritmo próprio, não sincronizado com as mudanças nas condições materiais de vida e com as novidades produzidas pelo conhecimento científico permitiu a sobrevivência, até hoje, dos princípios discriminadores dos doentes do peito.

Apesar disso, a condição 'misteriosa' da enfermidade foi perdendo impulso, deslocando os olhares cautelosos e estigmatizadores para as vítimas de outras patologias, em especial para o câncer e, a partir da década de 80, para os aidéticos. Refletindo a fase de 'migração’ parcial dos estigmas dos tísicos para os cancerosos, há alguns anos, a atriz Dercy Gonçalves foi questionada por um jornalista da Folha de S. Paulo sobre se era “encanada com alguma doença?” e ela respondeu nos seguintes termos: “Com tudo quanto é doença. Com câncer, com tuberculose. Há uns 40 anos eu tive tuberculose e foi um horror”.

A sociedade e a medicina não extinguiram os processos imputadores de marcas morais aos enfermos. Apenas atualizaram as doenças e os personagens que têm sido colocados como símbolos nocivos de uma modernidade assustadora.

A tuberculose transformara para sempre a vida de seus tributários. Mesmo que livres da moléstia e do isolamento hospitalar, os pectários sentiam-se atingidos pelas múltiplas exclusões sociais de que eram vitimados. É certo que muitos antigos enfermos 
conseguiram impor-se nos seus ambientes de origem, mas a tendência de muitos outros fracos dos pulmões foi criar raízes nos centros de cura e lá procurar reconstituir a vida e os laços sociais. As cidades-sanatórios transformaram-se então em redutos não da 'irmandade dos fracassados', mas sim daqueles que, lançando mão de estratégias variadas, saíram-se triunfantes da ameaça contagiosa e também dos tratamentos discriminatórios. 


\section{Conclusões}

Este livro reflete a trajetória pessoal costurada, de certa maneira, no tecido da historiografia específica sobre a História Social da Doença e do Doente. Fragmento de um contexto mais amplo, os temas da tuberculose e do tuberculoso compõem um enredo largo que, contudo, ainda não possui uma literatura suficiente para extraí-lo das aventuras iniciais.

Em linhas gerais, garante-se que o assunto exigiu uma moldura capaz de enquadrálo em um circuito historiográfico que incorporasse análises sobre a tuberculose como parte do estudo das moléstias, segundo os pressupostos da perspectiva médica. De regra, dois encaminhamentos orientam as interpretações sobre a doença também conhecida como Peste Branca.

Em uma ponta do novelo situam-se os estudos técnicos; em outra, as sugestões de adequação do contexto sócio-histórico à enfermidade e aos seus tributários. Entre as partes, um universo desconhecido que abriga 'visões de mundo', 'representações' e 'imaginários’. Ciência e dramas dão as mãos, teatralizando a sociedade e seus viventes na eterna luta contra a morte.

O percurso geral foi um convite desafiador a uma aventura calcada na intenção de estudos sobre o doente. Impossível seria, diga-se, qualquer trajeto que aliviasse a pressuposição da compreensão da doença. Antes de falar do doente, fez-se imperioso abordar a patologia que, afinal, gera os seus vários 'pacientes': os infectados, os especialistas médicos e paramédicos e, no final de contas, a sociedade como um todo.

Metodologicamente, o primeiro problema que se impôs foi o da determinação de um corpo documental forte o suficiente para sustentar os caminhos a serem percorridos. Pensou-se de início que o horizonte amplíssimo no qual se localizaria o trabalho seria inevitavelmente composto pela conjugação de vários núcleos.

De fato, seria fantasioso supor um estudo vocacionado, numa primeira parte, para a abrangência que não convidasse à conjugação de fontes plurais. Não bastaria, porém, um alinhamento de documentos que se mesclassem a esmo. Visitadas várias alternativas, de forma natural, os prontuários médicos mostraram-se como o fio condutor que poderia alinhar outros corpos informativos. Delineava-se o caminho que retracei.

Partindo dos prontuários médicos, um cosmo foi aberto. Surpresas ligadas às vicissitudes da medicina como 'ciência', 'conduta normativa', 'espelho do poder', 'agente da modernização’ indicavam possibilidades. Desdobrados os desafios, as figuras do médico e do doente afloravam, exibindo a provocante alternativa do 'eu', sujeito que repartiria com a análise da doença as preocupações de estudos.

Tanto a combinação do texto manuscrito expresso nos prontuários como fragmentos datilografados quanto a composição de um discurso ordenado segundo critérios 
de processos burocratizados como espontaneidades fugidias, tudo convidava à consideração do teor desses documentos como capitão para os demais. Centenas, milhares de registros clínicos, guardados de forma crítica e ameaçados de imediata extinção fomentaram um sentimento de angústia que premia o estudo da tuberculose sem que se esquecesse do tuberculoso e dos clínicos como personagens de sagas pessoais e coletivas.

Além da evidente 'revisão historiográfica' sobre o assunto, tornou-se pertinente a averiguação de textos médicos. Não seria possível percorrer o périplo expresso nestas páginas sem a exploração - procedida nos limites de um historiador e cientista social - da literatura médica. Sem ser jurista, não me furtei também à análise da legislação que enlaçava todo o contexto. Em nível público, ficou patente que a tuberculose serviu como mecanismo de relacionamento entre o Estado e os cidadãos. Doença e doente tornaram-se um binômio fundamental, dialético, para o duplo objetivo: da explicação do público e do privado.

A literatura - penso na ficção - somou-se aos relatos pessoais, poemas, cartas, tudo convidando a contemplação da problemática do 'eu doente' exposto à inevitável ação do ‘coletivo’. O Estado, a família, as comunidades próximas ao pectário emblemavam o 'externo' que contorna o doente. O privado impunha-se, concomitantemente, dando dimensão ao indivíduo como sujeito da doença e, assim, promovia a operação normatizadora do contexto.

A tuberculose e o tuberculoso, além de agentes da universalidade humana, adquirem âmbito nacional. Identificado com a cidadania, o doente é, em nosso caso, um brasileiro que tem seu 'mal' afetado pelas orientações que presidem as regras do cotidiano. O trabalho, o eventual seguro social, a família, o aparato médico e paramédico forçam um alinhavo intenso no cenário da coletividade. Somados esses elementos, catalisam-se no círculo da res publica.

Pensando na relação doença/doente em abrangência nacional, supondo a inevitável interpenetração do público e do privado, tem-se que aspectos diretamente ligados à modernização do país afetam o tratamento da tuberculose e do tuberculoso.

Instalados numa rotina do dia-a-dia, a doença e o doente passam pelos mesmos processos conjunturais que servem de cenário aos casos. Os avanços clínicos, a melhoria (ou não) dos serviços de atendimento, os hospitais, o controle e a proteção do Estado sobre a saúde coletiva; tudo somado espelha a geometrização progressiva das relações entre o Estado e o cidadão. A modernização compõe, assim, ângulos importantes que em dimensões amplas, inserem o país nos limiares da internacionalidade.

Sem dúvida, também por meio da doença o Estado modernizava seus critérios de relações com a sociedade. Ainda que os direitos individuais também atuem na correspondência do poder que se estabelece, parece necessário um mecanismo de incentivo aos 'eus' para que o sentido social da doença seja percebido.

De qualquer maneira, a identificação do 'eu' tuberculoso é elemento inédito na equação do poder. Extraindo do governo - ou das autoridades - a responsabilidade sobre a doença, fazendo com que o sujeito histórico, o 'paciente', também adquira personalidade, tem-se que seria fátuo supor apenas 'a doença como metáfora' e o doente como 'agente normatizado'. Assim, conclui-se que a doença existe tanto como 'fato médico' quanto ‘fato individual'. 
Como 'fato médico', a tísica e suas vítimas impunham soluções 'racionais' que, segundo a 'ideologia' da clínica e da epidemiologia, instruíram as formas de segregação e tratamento dos fimatosos. Como 'fato individual', a tuberculose agia como elemento redefinidor da existência, forçando os pronunciamentos pessoais que, feridos pela solidão, pelos estigmas e pela iminência da morte, oscilavam entre a aceitação do ordenamento médico-social e a revolta contra o ‘destino’ e a discriminação.

As visões sobre a tuberculose e o tuberculoso, na medida em que se inscrevem em linhas historiográficas, permite que a História Social da Doença e do Doente seja vista como uma unidade federativa do conhecimento na qual agregam-se múltiplas tensões coletivas e individuais.

Caminho com infinitos ramais que se cruzam, se opõem, se complementam, o estudo das patologias e de suas vítimas defronta-se com sucessivos labirintos construídos por discursos e por ações que, no final, deixam sempre a impressão da existência de fios soltos, por mais que se aplique no arremate do novelo, novelo composto por trajetórias de vidas marcadas pelo medo e pelo sofrimento.

Personagens históricos - penso, por exemplo, em Dercy Gonçalves, Adhemar de Barros, Afonso Arinos de Melo e Franco, Noel Rosa - convivem neste estudo com seres anônimos. Tuberculosos todos, cidadãos afetados pelas mesmas circunstâncias nacionais, os fracos do peito atuam como brasileiros que vivenciaram o processo histórico no qual se inscreve a doença - a tuberculose - e o doente - o tuberculoso.

No final da aventura que resultou neste livro, penso na eventualidade de algum leitor me exigir uma avaliação íntima sobre o que eu aprendi e registrei em palavras. Se isto um dia acontecer, tomarei emprestado uma afirmação de Albert Camus: "o que se aprende no meio dos flagelos: há nos homens mais coisas a admirar do que coisas a desprezar”. 


\section{Referências Bibliográficas}

ABREU, M. de. Recenseamento Torácico. Pôrto Alegre: Globo, 1938.

ABREU, M. de. La pesquisa de la tuberculosis en las colectividades supuestas sanas. In: SAYAGO, G. (Dir.). Tisiologia: undecimo curso de perfeccionamento. Cordoba: Universidad Nacional de Cordoba, 1943.

ABREU, R. de. Casa Destelhada. São Paulo: Editorial Paulista, 1933.

ALMEIDA, F. de \& LACAZ, C. da S. Micoses Bronco-Pulmonares. São Paulo: Melhoramentos, 1942.

ALPHONSUS, J. Rola-Moça. 2.ed. Rio de Janeiro: Imago, 1976.

ALVES, C. Obra Completa. Rio de Janeiro: José Aguilar, 1960.

ANDRADE, E. de. A Tuberculose é Curavel. Rio de Janeiro: Companhia Typographica do Brazil, 1906.

ARRUDA, M. de O. Relatorio apresentado a Exma. Inspectoria Geral de Hygiene do Imperio pelo Inspector da Provincia de São Paulo. Archivos de Hygiene e Saude PublicaI, 1(1):95112, jun., 1936.

ASSIS, M. de. Várias Histórias. Rio de Janeiro: W.M. Jackon Inc., 1957.

AUSTRAGESILO, A. Trabalhos Clinicos. Rio de Janeiro: Renascença, 1908.

AVELLAR, R. de. Numa Esquina do Planeta. Rio de Janeiro: Marques de Araujo \& Cia., 1932.

AZEVEDO, T. de. A tuberculose no Brasil pré-cabralino. Revista do Arquivo Publico Municipal de São Paulo, 7(49):201-204, abr. 1941.

BANU, G. L'Hygiène de la Race. Bucaresti et Paris: Imprimeria Nationala et Masson et Cie., 1939.

BARATA, O. da S. Antoninho da Rocha Marmo. São Paulo: Ave Maria, 1938.

BARIÉTY, M. \& COURY, C. Histoire de la Médecine. Paris: Fayard, 1963.

BASHKIRTSEFF, M. Diário. Porto Alegre: Globo, 1943.

BAUER, W.W. \& HULL, T. G. Health Education of the Public. Philadelphia: W.B. Saunders Co., 1937.

BERGOLLI, F. \& SARTORI, D. Psiche e carattere negli ammalati di petto. In: CAMPANI, A. \& COSTANTINI, G. (Dir.) Tisiologia nella Pratica Medica. Milano: A. Wassermann \& C., 1933. 
BERNARD, N. \& NÈGRE, L. Albert Calmette. Paris: Masson et Cie., 1939.

BERRY, N. O Sentimento de Identidade. São Paulo: Escuta, 1991.

BÍBLIA SAGRADA. 30.ed. Rio de Janeiro: Imprensa Bíblica Brasileira, 1974.

BIER, O. Noções Básicas de Imunoterapia e Quimioterapia. São Paulo: Melhoramentos, 1944.

BLOCH, M. Les Rois Thaumaturges. Paris: Gallimard, 1983.

BORGES, D. R. Seguro Social no Brasil. Rio de Janeiro: José Olympio, 1948.

BOTELHO, J. de O. O Problema Social e Scientifico da Tuberculose. São Paulo: Casa Garraux, 1910.

BOUREILLE, E. Le Devoir Sociale des Collectivites Envers les Tuberculeux Adultes et Indigents. Neumours: Henry Bouloy, 1901.

BRITTO, A. Organisação anti-tuberculosa. Annaes do Quinto Congresso Brasileiro de Hygiene. Rio de Janeiro, 1929.

BRITTO, L. P. L. Medicina e Discurso. Campinas: Papirus, 1988.

BRONTE, E. Wuthering Heights. New York: Triangle, 1939.

CABANÈS Le Cabinet Secret de L'Histoire. Paris: Albin Michel, 1937. 4v.

CAIUBY, A. Noites de Plantão. São Paulo: Monteiro Lobato e Cia., 1923.

CALMETTE, A. La Vaccination Préventive Contre la Tuberculose par le “BCG”. Paris: Masson et Cie., 1927.

CARDOSO, M. H. Por Onde Andou Meu Coração. 2.ed. Rio de Janeiro: José Olympio, 1968.

CARPENTIER, E. Famines et épidémies dans l’histoire du XIVè. Siècle. Annales, 17(6):10621092, nov.-dez. 1962.

CASTIGLIONI, A. History of Tuberculosis. New York: Froben, 1933.

CASTIGLIONI, A. História da Medicina. São Paulo: Editora Nacional, 1947. 2v.

CAVAlCANTI, A. Como Evitar e Curar a Tuberculose. Belo Horizonte: Santa Maria, 1935.

CECILIO, E. Demônios e Semideus. Rio de Janeiro: Maia \& Schmidt, 1933.

CENDRERO, O. Elementos de Higiene. 14.ed., Caracas: s.c.p., 1942.

CESCO, N. de T. São José dos Campos: uma visão da fase sanatorial. São José dos Campos: Fundação Cultural Cassiano Ricardo, 1992.

CEVIDALLI, A. Compendio di Medicina Legale. 2.ed. Roma: Societá Libraria, 1928.

CLAVREUL, J. A Ordem Médica. São Paulo: Brasiliense, 1983.

COLLARES JUNIOR. Vultos e Factos Brasileiros. Victoria: Coelho \& Cia., 1930.

CORRÊA, I. de L. A. Documentos Anátomo-Clínicos sobre a Tuberculose Pulmonar em São Paulo, 1949. São Paulo: Tese de Cátedra apresentada à Faculdade de Medicina da Universidade de São Paulo. 
CORVELLO JUNIOR, M. Commentarios sobre tuberculose. Revista Paulista de Tisiologia, 2(2):96-104, mar.-abr., 1936.

COSTE, F. Du Symptome a la Maladie. Paris: A. Maloine, 1915.

COUTO, M. No Brasil Só Há Um Problema Nacional: a educação do povo. Rio de Janeiro: Typographia do Jornal do Commercio, 1933.

COUTO, R. Cabocla. 4.ed. São Paulo: Clube do Livro, 1949.

D’AUREVILLY, J.A. B. Léa. Paris: Gründ, s.d.

DANTAS, P. As Águas Não Dormem... São Paulo: Brasiliense, 1946.

DANTAS, P. Cidade Enferma. São Paulo: Brasiliense, 1950.

DELARUE, J. La Tuberculose. 10.ed. Paris: PUF, 1972.

DUBOS, R. \& J. The White Plague. Boston: Little, Brown \& Co., 1952.

DUMAS FILHO, A. A Dama das Camélias. Lisboa: Europa-América, 1977.

ESTEVES, H. A tuberculose pulmonar no Pará. Revista Brasileira de Tuberculose, 8(62):560573, jul., 1939.

ETZEL, E. Um Médico no Século XX: vivendo transformações. São Paulo: Nobel/Edusp, 1987.

FARIA, A. de. O problema da tuberculose no preto e no branco e relações de resistência racial. Estudos Afro-Brasileiros. Rio de Janeiro: s.c.p., 1935.

FARIA, L. F. et al. Índice tuberculínico entre escolares da estância climática de Campos do Jordão. Revista Paulista de Tisiologia, 6(6):407-422, nov.-dez. 1940.

FERREIRA, C. Tuberculose e Sanatorios. São Paulo: Typographia Brasil, 1900.

FERREIRA, C. Instrucções Populares sobre a Tuberculose. São Paulo: Associação Paulista dos Sanatórios Populares, 1908.

FERREIRA, C. The latest progress of the anti-tuberculosis in Brazil. International Conference on Tuberculosis. São Paulo: Vanorden, 1913.

FERREIRA, C. Discursos e Conferencias: 1892-1939. São Paulo: Typographia Rossolillo, s.d.a.

FERREIRA, C. Le mouvement antituberculeux ai Bresil. Tuberculosis, 2(7):308-320, s.d.b.

FERREIRA, C. Estudos e Conferencias. São Paulo: São Paulo Editora, 1943.

FONSSAGRIVES, J.-B. Thérapeutique de la Phthisie Pulmonaire. 2.ed., Paris: J.-B. Baillière et Fils, 1880.

FOUCAULT, M. O Nascimento da Clínica. Rio de Janeiro: Forense-Universitária, 1977.

FRAGA, C. Medicina e Humanismo. Rio de Janeiro: Guanabara, 1942.

FRANCO, A. A. de M. e. A Alma do Tempo. Rio de Janeiro: José Olympio, 1961.

FRANCO, G. Exama pulmonar sistematico das coletividades. Revista Paulista de Tisiologia, 3(1):68-81, jan.-fev. 1937. 
FRANCO, F. de M. Ensaio Sobre as Febres. Lisboa: Academia Real de Sciencias, 1829.

FREITAS, O. de. O maior de todos os males. Annaes do Quinto Congresso Brasileiro de Hygiene. Rio de Janeiro, 1929. 1v.

FREITAS, O de. Minhas Memórias de Médico. São Paulo: Editora Nacional, 1940.

GALLIS, A. A Sachristia. Lisboa: Gomes de Carvalho, 1903.

GODINHO, V. \& ALVARO, G. Tuberculose. São Paulo: Serviço Sanitário do Estado, 1899.

GODINHO, V. Sanatorios e Tuberculose. São Paulo: Typographia do Diario Official, 1902.

GOFFMAN, E. Manicômios, Prisões e Conventos. São Paulo: Perspectiva, 1974.

GOFFMAN, E. A Representação do Eu na Vida Cotidiana. Petrópolis: Vozes, 1975.

GONÇALVES, C. P. Seleção Médica do Pessoal da FEB. Rio de Janeiro: Ministério da Guerra, 1951.

GONZAGA, A. G. Organização das estancias climaticas de tratamento e de repouso. Revista Paulista de Tisiologia, 1(3-4):65-69, mar.-abr. 1935.

GONZAGA, O. Seara Médica... São Paulo: Revista dos Tribunais, 1941.

GOOD, P. Higyène et Morale. 15.ed., Paris: s.c.p., 1923.

GOUNCOURT, E. \& J. Madame Gervaisais. Paris: Gallimard, 1982.

GOUVEIA, A. Como interromper a gravidez na tuberculose pulmonar. Revista Paulista de Tisiologia, 2(6):467-474, nov.-dez. 1936.

GRELLET, I. \& KRUSE, C. Histoires de la Tuberculose. Paris: Ramsay, 1983.

GRIECO, J. \& CARDOSO, F. A. A Tuberculose em São Paulo. São Paulo: Instituto de Higiene da Universidade de São Paulo, 1939.

GRIECO, J. Contribuição para o estudo da tuberculose no preto na cidade de São Paulo. Revista Paulista de Tuberculose, 8(4):211-266, jul.-ago. 1942.

GRMEK, M. D. Les Maladies à L'Aube de la Civilisation Occidentale. Paris: Payot, 1983.

GROB, G. N. The Social History of Medicine and Disease in America: problems and possibilities. Journal of Social History, 19(4):391-409, 1977.

GUILlAUME, P. Du Désespoir au Salut. Paris: Aubier, 1986.

HADDAD, J. A. Poemas. São Paulo, Cultura, 1943, 3v.

HERZLICH, C. \& PIERRET, J. Malades D’Hier, Malades D'Aujourd'hui. Paris, Payot, 1984.

HILLEMAND, P. \& GILBRAIN, E. Les fièvres romantiques. In: SENDRAIL, M. (Org.). Histoire Culturelle de la Maladie. Toulouse: Privat, 1980.

HIPPOCRATES. Opera. London: s.c.p., 1911. 1v.

HOMEM, J. V. T. As Febres do Rio de Janeiro. Rio de Janeiro: Livraria Classica, 1877.

HOMEM, J. V. T. Lições de Clinica Medica. Rio de Janeiro: Lopes do Couto \& C., 1882. 3.v. 
ISAACSON, M. O Methodo de Friedmann Para a Prophilaxia e Tratamento da Tuberculose. Curytiba: Placido e Silva \& Cia., 1929.

JACOB, F. A Estátua Interior. Lisboa: Dom Quixote, 1988.

JARDIM, L. P. Elementos de Hygiene Militar. São Paulo: Typographia Paulista, 1894.

JONES, B. M. Health-Seekers in the Southwest. Norman, University of Oklahoma Press, 1967.

JOSEPH, B. Amor Que Santifica. 2.ed., Rio de Janeiro: Centro Brasileiro de Publicidade, 1936.

KNOPF, S.A. \& FERREIRA, C. A Tuberculose Como Doença Popular e Meios de Combate-la. São Paulo: Escola Typographica Salesiana, 1901.

KOCH, R. La etiologia de la tuberculosis.Arquivos Brasileiros de Tuberculose e Doenças do Tórax, 40(1981):11-34.

LA VAUDÈRE, J. de. Os Androgynos. Barcelona: Galante, s.d.

LAÍN ENTRALGO, P. Historia de la Medicina. Barcelona: Científico Médica, 1954.

LAÍN ENTRALGO, P. El Médico y el Enfermo. Madrid: Guadarrama, 1969.

LAÍN ENTRALGO, P. La Relación Médico-Enfermo. Madrid: Alianza, 1983.

LAÍN ENTRALGO, P. Antropologia Médica. Barcelona: Salvat, 1984.

LANDERER, A. Le Traitment de la Tuberculose. Paris: J.-B. Baillière 7 Fils, 1899.

LAPLANTINE, F. Antropologia da Doença. São Paulo, Martins Fontes, 1991.

LAZAETA ACHARAN, M. Tisis y Tuberculosis. Santiago del Chile: Cultura, 1933.

LE GOFF, J. \& SOURNIA, J.-C. Les Maladies Ont une Histoire. Paris: Seuil, 1985.

LEITE, S. Cartas dos Primeiros Jesuítas do Brasil. São Paulo: Comissão do IV Centenário, 1957, 3v.

LEME, J. D. Ilha da Esperança. Campinas: Casa do Livro Azul, 1944.

LÉONARD, J. La Médecine Entre les Pouvoirs et les Savoirs. Paris: Aubier Montaigne, 1981.

LÉONARD, J. Comment peut-on être pasteurien? In: SALOMON-BAYET, C. (Org.). Pasteur et la Révolution Pastorienne. Paris, Payot, 1986.

LESER, W. S. P. Contribuição Para o Estudo dos Métodos Estatísticos Aplicáveis à Medicina e Higiene, 1933. São Paulo: Tese de Doutorado apresentada à Faculdade de Medicina da Universidade de São Paulo.

LOPES, I. de S. Organização antituberculosa em São Paulo. Revista Paulista de Tisiologia, 1(7-8): 291-302, jul.-ago. 1935.

LUMIÈRE, A. Tuberculose: contagion, hérédité. 2.ed. Lyon: Joannés \& Cie., 1931.

MAC DOWELL, A. O Problema Social da Tuberculose. Rio de Janeiro: s.c.p., 1932.

MAC DOWELL, A \& FERREIRA, J. C. Tuberculose inapparente na mulher gravida. Revista Brasileira de Tuberculose, 8(61):458-469, mai.-jun. 1939. 
MALAGUETA, I. A psychotherapia no tratamento da tuberculose pulmonar. In: FRAGA, C. (Org.). Tuberculose Pulonar. Rio de Janeiro: Calvini Filho, 1931.

MARINHO, A. et al. Tuberculose e Previdência Social. Rio de Janeiro: Serviço de Propaganda e Educação Sanitária do Ministério da Educação e Saude Publica, 1939.

MARQUES, A. Importância do Relacionamento Profissional no Campo Médico-Hospitalar, 1983. São Paulo: Dissertação de Mestrado apresentada à Faculdade de Serviço Social da Pontifícia Universidade Católica.

MARTINS, A. N. A Campanha Contra a Tuberculose em São Paulo. São Paulo: s.c.p., 1944.

MASCARENHAS, R. dos S. A tuberculose e a imigração nacional: o estado de São Paulo. Arquivos da Faculdade de Higiene e Saúde Pública da Universidade de São Paulo, 3(1):87207, jun., 1949; 3(2):219-324, dez., 1949; 4(6):69-121, jun., 1950.

MASCARENHAS, R. dos S. Contribuição para o Estudo da Administração dos Serviços Estaduais de Tuberculose em São Paulo, 1953. São Paulo: Tese de Cátedra apresentada à Faculdade de Higiene e Saúde Pública da Universidade de São Paulo.

MCKEOWN, T. The Modern Rise of Population. London: Edward Arnold, 1977.

MCKEOWN, T. \& IOWE, C.R. Introducción a la Medicina Social. 4.ed., México, D. F.: Siglo Veintiuno, 1989.

MCKEOWN, T. As Origens da Doença Humana. Lisboa: Caminho, 1990.

MCNEILL, W. H. Plagues and Peoples. New York: Anchor, 1976.

MELLO, C. e Almas em Delirio. São Paulo: O Pensamento, 1912.

MÉTALL, R. A. Problemas Atuais de Seguro Social. Rio de Janeiro: A. Coelho Branco Filho, 1944.

MOLL, A. M. Aesculapius in Latin America. New York: Argosy-Antiquarian, 1969.

MONIN, E. L'Hygiène des Riches. Paris: Octave Doin et Fils, 1891.

MONTENEGRO, T. H. Tuberculose e Literatura. 2.ed., Rio de Janeiro: A Casa do Livro, 1971.

MORAES, C. V. de Contribuição ao Estudo do Contrôle da Tuberculose na Estância HidroMineral e Climatérica de São José dos Campos. São Paulo: Escolas Profissionais Salesianas, 1939.

MORAES, C. V. O Que Foi o Centro de Saude de São José dos Campos em 1938. São José dos Campos, 1939. (Mimeo.)

MURGER, H. Scènes de la Vie Bohéme. Paris: Gründ, 1936.

NÉBIAS, J. O. et al. Acidentes e complicações da operação de Jacobaeus. Revista Paulista de Tisiologia, 3(6):479-519, nov.-dez. 1937.

NETTO, C. Treva. Lisboa: Chardron, 1924.

NEVES-MANTA, I. de L. Borba Sangue e Outras Novellas. Rio de Janeiro: Azevedo, 1930.

NOBRE, A. Correspondência. 2.ed., Lisboa: Imprensa Nacional, 1982. 
NOGUEIRA, O. Estudo de Experiências Sociológicas e Psicológicas do Tuberculoso Pulmonar no Estado de São Paulo, 1945. São Paulo: Tese de Mestrado apresentada à Divisão de Estudos Post-Graduados da Escola Livre de Sociologia e Política de São Paulo.

NOGUEIRA, O. Vozes de Campos do Jordão. São Paulo: Sociologia, 1950.

NOGUEIRA, O. Tanto Preto Quanto Branco. São Paulo: T. A. Queiroz, 1985.

NOGUEIRA, O. Negro Político, Político Negro. São Paulo: Edusp, 1992.

PARANHOS, U. Floradas na Serra. Folha da Manhã, out., 1939a.

PARANHOS, U. A proposito de ‘Floradas na Serra’. Folha da Manhã, nov., 1939b.

PARDELLAS, R. \& PASSOS, M. P. O tuberculoso em face da legislação. Revista Brasileira de Tuberculose, 10(75):251-286, mai.-jun., 1941.

PAULA, A. de. Dispensário Antituberculoso. Rio de Janeiro: José Olympio, 1944.

PAULA, A. de. O ensino de tisiologia. Temas de Tisiologia. Rio de Janeiro: Ateneu, 1949.

PAULA, A. de. A doença de Manuel Bandeira. In: SILVA, M. de C. (Org.). Homenagem a Manuel Bandeira. Rio de Janeiro: Presença, 1989.

PAULO FILHO, P. História de Campos do Jordão. Aparecida: Santuário, 1986.

PEIXOTO, A. Elementos de Hijiene. Rio de Janeiro/Paris: Francisco Alves \& Cia. e Allaud, Alves \& Cie., 1913.

PEIXOTO, A. Um Seculo de Cultura Sanitaria. São Paulo: O Estado de S. Paulo, 1923.

PEREIRA, A. O. Fio de Prumo. 3.ed., Rio de Janeiro: José Olympio, 1976.

PERESTRELLO, D. Quinta Coluna Contra a Saúde. Rio de Janeiro: Serviço Nacional de Educação Sanitária, 1941.

PITANGA, G. Jacques Stéphani. Revista Brasileira de Tuberculose, 3(8):357-364, nov.-dez., 1933.

PÔRTO, A. A vida Inteira que Podia Ter Sido e que Não Foi: trajetória de um poeta tísico, 1997. Rio de Janeiro: Tese de doutorado apresentada ao Programa de Pós-Graduação em Saúde Coletiva do Instituto de Medicina Social da Universidade Estadual do Rio de Janeiro.

PRADO, J. N. de A. “Floradas na Serra” e a psicopatologia. Gazeta Clinica, 37(12):457-460, dez. 1939.

PRADO, X. do. Sanatorio de medico. Revista Paulista de Tisiologia, 3(2):152-162, mai.-jun., 1936.

QUEEN, S. A. \& MANN, D. M. Social Patology. New York: Thomas Y. Crowell Company, 1925.

QUEIROZ, D. S. Floradas na Serra. Rio de Janeiro: José Olympio, 1939.

REGOLA. Sanitaria Salermitana. Salerno: Saturnia, 1975.

REVEL, J. Corps. In: LE GOFF, J. et al. (Orgs.) La Nouvelle Histoire. Paris: CEPL, 1978. 
REVEL, J. \& PETER, J.-P. O corpo: o homem doente e sua história. In: LE GOFF, J. \& NORA, P. (Orgs.) História: novos objetos. Rio de Janeiro: Francisco Alves, 1976.

RIBEIRO, L. A Luta Contra a Tuberculose no Brasil. Rio de Janeiro: s.c.p., 1956.

RODRIGUES, N. F. Memórias. Rio de Janeiro: Correio da Manhã, 1967.

ROSEN, G. People, disease, and emotion: some newer problems for research in medical history. Bulletin of the History of Medicine, 41(1):5-23, jan.-fev., 1967.

RUFFINO NETTO, A. \& PEREIRA, J. C. Mortalidade por tuberculose e condições de vida: o caso do Rio de Janeiro. Saúde em Debate, 12:27-34, 1981.

RUFFINO NETTO, A. \& PEREIRA, J. C. Saúde-doença e sociedade: a tuberculose - o tuberculoso. Textos de Apoio. Rio de Janeiro: Abrasco, 1985.

SAND, G. História da Minha Vida. Rio de Janeiro: José Olympio, 1947. 6v.

SAND, G. Un Hiver à Majorque. Paris: Librairie Générale Française, 1984.

SANTOS FILHO, L. História Geral da Medicina Brasileira. São Paulo: Hucitec/Edusp, 1977. $1 \mathrm{v}$.

SCHWARCZ, R. Embarazo y Tuberculosis. Buenos Aires: El Ateneo, 1938.

SCLIAR, M. et al. Doença e estigma. Cadernos de História e Saúde, 2:6-28, 1992.

SCOLNIK, J. Como Cura las Enfermedades la Medicina Naturalista. 2.ed., Córdoba: s.c.p., 1940.

SCHMIDT, A. O Gigante Invisível. São paulo: Spes, c. 1944.

SÉRGIO, P. Poemas da Eterna Caminhada. São Paulo: Clube de Poesia, 1950.

SETUBAL, P. Confiteor. 8.ed., São Paulo: Saraiva, 1949.

SIGERIST, H. Introduction à la Médecine. Paris: Payot, 1932.

SIGERIST, H. Civilization and Disease. Chicago: The University of Chicago Press, 1943.

SIGERIST, H. Hitos en la Historia de la Salud Pública. 3.ed., México, D.F.: Siglo Veintiuno, 1987.

SILVA, A. C. P. e. Direito à Saúde. Brasil: s.c.p., 1934.

SILVA, G. P. 25 Anos de Psicanálise. Rio de Janeiro: Império, 1959.

SILVEIRA, J. Pela Campanha Anti-Tuberculosa. Bahia: Imprensa Regina, 1939.

SOARES, J. B. de S. \& FARIA, L. F. A tuberculose nos japoneses do Brasil. Revista Paulista de Tuberculose, 5(5):291-304, ago.-set. 1939.

SOARES, J. B. de S. O psychismo dos tuberculosos. Folha da Manhã, out., 1939.

SOARES, J. B. de S. Tuberculose e psychismo. Revista da Associação Paulista de Medicina, 16(3):190-209, mar., 1940.

SOBRAL, F. F. Gerações Doentes, Herança Mórbida. Bello-Horizonte: Imprensa Official, 1932.

SOKOLOFF, B. A Penicilina. Rio de Janeiro: Científica, 1946. 
SONTAG, S. Illness as Metaphor. New York: Vintage, 1978.

SONTAG, S. Aids and its Metaphors. New York: Farrar, Straus \& Giroux, 1988.

SOURNIA, J.-C. Histoire et Médecine. Paris: Fayard, 1982.

SOURNIA, J.-C. \& RUFFIE, J. As Epidemias na História do Homem. Lisboa: Edições 70, 1986.

SOUTO, V. Tuberculose Pulmonar: noções indispensáveis a todos. Rio de Janeiro: Francisco Alves, 1937.

SOUZA, C. de. As Mulheres Fataes. Rio de Janeiro: Pimenta de Mello \& C., 1928.

SOUZA, M. C. A. de. Tratamento Sanatorial da Tuberculose Pulmonar. Rio de Janeiro: Calvino Filho, 1934.

SOUZA, R. de. Em Busca da Etio-Patogenia e de uma Terapêutica Científica para o Mal de Hansen e para a Tuberculose. São Paulo e Rio de Janeiro: s.c.p, 1941-1947.

SOUZA, R. de P. O papel do semi-internato como auxiliar na luta antituberculose. Revista Paulista de Tisiologia, 5(5): 317-335, set.-out. 1939.

SOUZA, R. de P. et al. Clima e Tuberculose. São Paulo, Publicitas, 1936.

STÉPHANI, J. Guia do Tuberculoso e do Predisposto, São Paulo: Editora Nacional, 1933.

STOWE, H. B. A Cabana do Pai Tomás. São Paulo: Saraiva, 1962, 2v.

TARTARIN, A. C. Tuberculose et Sanatorium. Paris: C. Naud, 1902.

TEIXEIRA, N. L. O Suicídio. Curitiba: Guaíra, 1947.

THÉO-FILHO. Dona Dolorosa. 3.ed., Rio de Janeiro: Leite Ribeiro, 1923.

THOMAS, L. V. El Cadáver. México, D.F.: Fondo de Cultura Económica, 1989.

TOLEDO, J. Escola Brasileira. São Paulo: Imprensa Methodista, 1925.

TRANCOSO, J. G. Memorial de Um Passageiro de Bonde. São Paulo: Cultura Brasileira, 1938.

VIEIRA, J. G. A Ronda do Deslumbramento. Rio de Janeiro, Empreza Brasil, 1922.

WALKSMAN, S. A. The Conquest of Tuberculosis. Berkeley: California Univesity Press, 1964.

WHITAKER, E. de A. Os “Milagres” do “Padre de Poá”. São Paulo: s.c.p., 1944.

WILSON, C. M. Ambassadors in White. New York: Henry Holt and Company, 1942.

WOILLEZ, E. J. Dicctionnaire de Diagnostic Medical. 2.ed., Paris: J.-B. Baillière et Fils, 1870.

ZALAMANSKY, H. L'étude des contenus, étape fondamentale de la sociologie de la littérature contemporaine. In: ESCARPIT, R. (Org.). Le Littéraire et le Social. Paris: Flammarion, 1970. 
Formato: $16 \times 23 \mathrm{~cm}$

Tipologia: Times New Roman

Bauer Bodoni BT

Papel: Pólen Bold $70 \mathrm{~g} / \mathrm{m}^{2}$ (miolo)

Cartão Supremo $250 \mathrm{~g} / \mathrm{m}^{2}$ (capa)

Fotolitos: Laser vegetal (miolo)

Quadratim Artes Gráficas Ltda. (capa)

Impressão e acabamento: Armazém das Letras Gráfica e Editora Ltda.

Rio de Janeiro, dezembro de 2001.

Não encontrando nossos títulos em livrarias, contactar a EDITORA FIOCRUZ:

Av. Brasil, 4036 - 1ํandar - sala 112 - Manguinhos

21040-361 - Rio de Janeiro - RJ

Tel.: (21) 3882-9006, 3882-9039 e 3882-9041

Telefax: (21) 3882-9006 e 3882-9007

http//www.fiocruz.br/editora

e-mail: editora@fiocruz.br 
Próximos livros da coleção

Antropologia e Saúde

Antropologia, Saúde e Envelhecimento Maria Cecília de Souza Minayo

e Carlos E. A. Coimbra Jr. (orgs.)

Frágeis Deuses: profissionais da emergência entre os danos da violência

e a recriação da vida

Suely Ferreira Deslandes

ções sobre a doença e suas transformações ao longo da História; a administração sanitária da tuberculose no Brasil e as propostas assistenciais; a construção da especialidade médica e os conflitos doutrinários; a educaçāo sanitária e a promoção da moralidade; a trajetória dos tuberculosos e o estigma da doença; a rotina sanatorial e o cotidiano dos pacientes; a tisiologia e o arsenal clínicocirúrgico; a experiência da doença e as relaçôes com os sãos.

A importância de seu estudo se revela também na utilizaçāo de fontes documentais diversas, com destaque para as obras literárias e os prontuários médicos, documentos raramente preservados, que se constituem em peças fundamentais na composição da história social da doença e do doente.

Ângela Porto

Doutora em Saude Coletiva pelo Instituto de Medicina Sorial/LERJ e pesquisadora titular da Casa de Oswaldo Cruzfliocruz

\section{Claudio Bertolli Filho}

É formado em História e Ciéncias Sociais, com especializacào em Saude Coletiva pelo Instituto de Saúde da Secretaria de Estado da Saúde de Sảo Paulo e doutor em História. Atualmente é docente da Faculdade de Arquitetura, Artes e Comunicação e do Programa de Pós-Graduação em Educação para a Ciéncia da Faculdade de Ciências, ambos da Universidade Estadual Paulista (Lnesp), campus de Bauru. 
O campo das investigações antropológicas sobre a saúde e a doença tem experimentado rápida expansão nos principais centros acadêmicos internacionais. Este crescimento acontece também no Brasil, onde se verifica a consolidação de linhas de pesquisa representando as mais variadas vertentes teóricas da antropologia da saúde em programas de pós-graduação, tanto em saúde coletiva como em antropologia. Com a coleção Antropologia e Saúde pretende-se contribuir para a disseminação da produção de alta qualidade, oriunda de centros de pesquisa e pós-graduação nacionais. Visa-se também a promover a divulgação de textos de autores estrangeiros considerados clássicos neste campo. Espera-se, com esta coleção, contribuir para o desenvolvimento e a divulgação de referenciais teóricos e metodológicos que suscitem perspectivas inovadoras na abordagem interdisciplinar do processo saúdedoença. A longo prazo, Antropologia e Saúde deverá estimular um crescente diálogo entre as ciências sociais/antropologia e as ciências da saúde/saúde coletiva no Brasil. 